Pontifícia Universidade $_{\text {do Rio de Janeiro }}$

\author{
Juliana Cunha Menezes
}

\title{
AVALIAÇÃO DE TRADUÇÃO DE POESIA: \\ $A$ anotação na busca pelo consenso
}

Tese de Doutorado

Tese apresentada ao Programa de Pós-graduação em Estudos da Linguagem da PUC-Rio como requisito parcial para obtenção do grau de Doutor em Letras/Estudos da Linguagem.

Orientador: Prof. Paulo Fernando Henriques Britto Coorientadora: Profa. Maria Cláudia de Freitas 


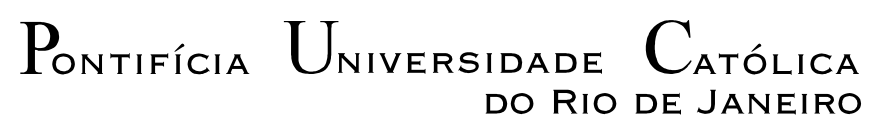

DO RIO DE JANEIRO

\section{Juliana Cunha Menezes}

\section{AVALIAÇÃO DE TRADUÇÃO DE POESIA: A anotação na busca pelo consenso}

Tese apresentada ao Programa de Pós-Graduação em Letras da PUC-Rio como requisito parcial para obtenção do grau de Doutor em Estudos da Linguagem do Departamento de Letras do Centro de Teologia e Ciência Humanas da PUC-Rio. Aprovada pela Comissão Examinadora abaixo assinada.

Prof. Paulo Henriques Britto Orientador Departamemento de Letras - PUC-Rio

Prof. Maria Cláudia de Freitas

Coorientadora Departamemento de Letras -PUC-Rio

Prof. Marcia do Amaral Peixoto Martins Departamento de Letras - PUC-Rio

Prof. Caetano Waldrigues Galindo UFPR

Profa. Monah Winograd Coordenadora Setorial do Centro de Teologia e Ciências Humanas - PUC-Rio 
Todos os direitos reservados. É proibida a reprodução total ou parcial do trabalho sem autorização da universidade, da autora, do orientador e da coorientadora.

\section{Juliana Cunha Menezes}

Bacharel e Licenciada em Letras (Inglês/ Literaturas de Língua Inglesa) pela UERJ (2009). Certificada pelo curso de Formação de Tradutores (Inglês-Português) da PUC-Rio (2010). Mestre em Letras/ Estudos da Linguagem pela PUC-Rio (2012), e doutora em Letras/ Estudos da Linguagem pela mesma universidade (2017). É professora de inglês.

Ficha Catalográfica

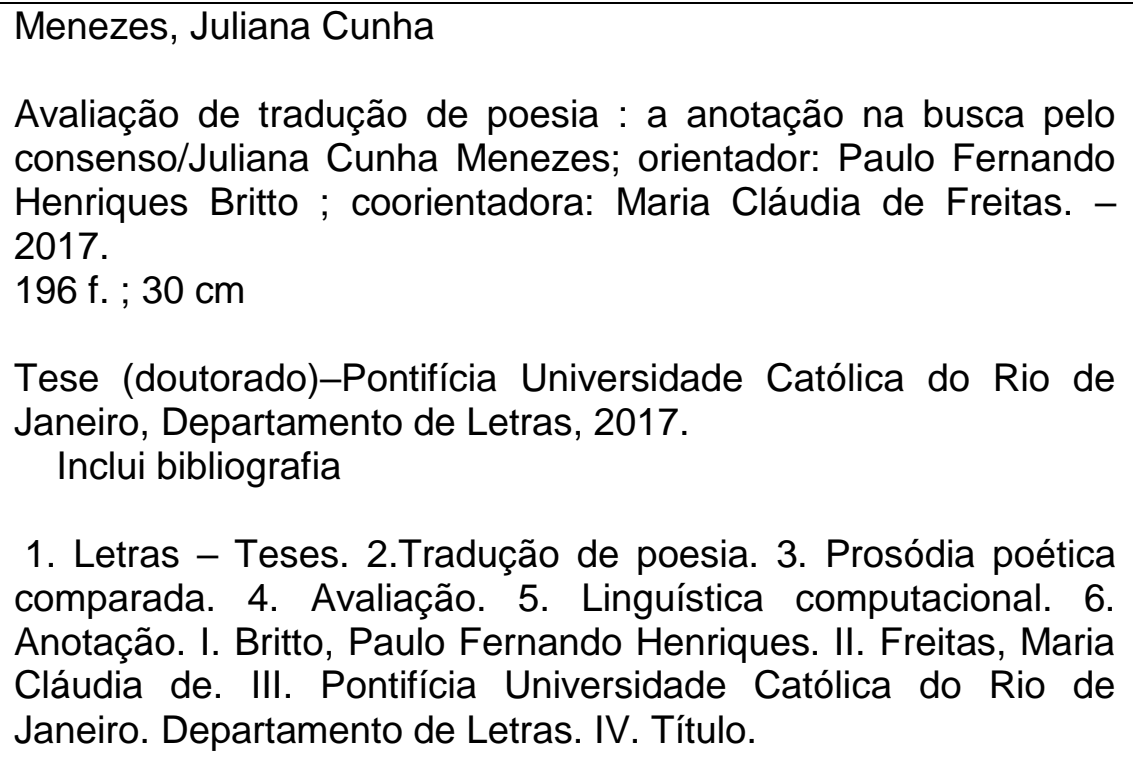

Avaliação de tradução de poesia : a anotação na busca pelo consenso/Juliana Cunha Menezes; orientador: Paulo Fernando Henriques Britto ; coorientadora: Maria Cláudia de Freitas. 2017.

196 f. ; $30 \mathrm{~cm}$

Tese (doutorado)-Pontifícia Universidade Católica do Rio de Janeiro, Departamento de Letras, 2017.

Inclui bibliografia

1. Letras - Teses. 2.Tradução de poesia. 3. Prosódia poética comparada. 4. Avaliação. 5. Linguística computacional. 6. Anotação. I. Britto, Paulo Fernando Henriques. II. Freitas, Maria Cláudia de. III. Pontifícia Universidade Católica do Rio de Janeiro. Departamento de Letras. IV. Título. 


\section{Agradecimentos}

À CAPES, cujo financiamento permitiu que eu me dedicasse exclusivamente a esta pesquisa, nos dois primeiros anos e no último período do doutorado.

Ao meu orientador, Paulo Britto, e à minha coorientadora, Maria Cláudia Freitas, cujo rigor, paciência e dedicação me ajudaram a trilhar esse caminho tão árduo.

Ao CMG Guilherme e ao CMG Fabrício (Colégio Naval - Marinha do Brasil), por terem me concedido um dia de folga durante a semana, no sexto e no sétimo período, para que eu pudesse me dedicar ao doutorado.

À Chiquinha, pela constante ajuda.

Às professoras da PUC-Rio, Helena Martins, Maria Cláudia de Freitas, Maria Paula Frota, Liliana Bastos e Inés Miller, pelos grandes ensinamentos.

Aos professores, Márcia Martins (PUC-Rio) e Caetano Galindo (UFPR), membros da minha banca de qualificação, cujos comentários e sugestões foram fundamentais para o aprimoramento desta tese.

Aos voluntários, Ana Carolina Dantas, Eduardo Friedman, Adriano Scandolara e Matheus Mavericco, por terem se disponibilizado a me ajudar, e pelos preciosos comentários.

À minha mãe, Balbina, e ao meu pai, Aércio, por sempre acreditarem em mim.

Aos amigos da PUC-Rio, Guilherme, Elisa, Célia, Arinalva Paula e Sarah, pela troca de ideias e de risadas.

À amiga Rosângela, por sempre mostrar interesse pelos meus estudos.

Às grandes amigas Aline e Ana Paula, por terem me proporcionado, no último período do doutorado, um lar calmo e alegre, para que eu pudesse finalizar minha tese com tranquilidade.

A todos os meus amigos, pelos momentos de descontração.

A todos, enfim, que possam ter contribuído de alguma forma para esta pesquisa. 


\section{Resumo}

Menezes, Juliana Cunha; Britto, Paulo Henriques; de Freitas, Maria Cláudia. Avaliação de tradução de poesia: a anotação na busca pelo consenso. Rio de Janeiro, 2017, 196p. Tese de Doutorado - Departamento de Letras, Pontifícia Universidade Católica do Rio de Janeiro.

Este estudo, que se insere no viés pós-estruturalista, tem como hipótese a possibilidade de se estabelecerem categorias capazes de instrumentalizar avaliações minimamente consensuais de traduções de poesia. Assim, dadas duas ou mais traduções de um poema, submetidas a dois ou mais avaliadores que adotem categorias uniformes de análise, suas avaliações, ainda que não idênticas, terão em comum alguns pontos relevantes. A busca pelo consenso é feita através da anotação, uma das atividades da Linguística Computacional, que consiste em identificar e classificar um certo fenômeno linguístico, utilizando rótulos, etiquetas, categorias, em um determinado corpus para, assim, atingirmos um determinado objetivo. Os objetivos da tese são (a) fornecer, aos interessados em tradução de poesia, insumos para se poder avaliar, de forma minimamente consensual, traduções de poemas; e (b) explicitar, sistematizar e validar categorias do nível semântico-lexical, e descrever e confirmar categorias do nível formal (níveis métrico e rimático) e do plano de recursos sonoros, a fim de que possam ser usadas para embasar avaliações minimamente consensuais de traduções de poesia. A pesquisa apresenta três etapas. Na primeira, a anotação é utilizada como metodologia na busca pelo consenso. Nessa etapa, anotações de poemas originais e de traduções foram feitas por diferentes estudiosos. Ao comparar essas anotações em busca de consenso, confirmei/validei ou reformulei as categorias. O consenso permite confirmação e validação, já a falta dele abre espaço para reformulações e refinamentos. Na segunda etapa, a metodologia de Britto, com algumas observações adicionais, foi utilizada para analisar os resultados oriundos da primeira etapa. Objetiva-se, por meio de tal metodologia, verificar se os aspectos mais relevantes dos níveis métrico, rimático, semântico-lexical e do plano de recursos sonoros (aliterações, assonâncias e recursos afins) dos poemas originais foram recriados nas traduções. E na terceira, são utilizados os resultados da segunda etapa a fim de se produzir elementos para uma possível avaliação de traduções de poesia: entre duas traduções do soneto 130 de Shakespeare, 
verificar qual seria a mais fiel ao original. A hipótese foi comprovada quanto ao nível formal e ao plano de recursos sonoros, mas não quanto ao nível semântico-lexical. A validação das categorias do nível semântico-lexical pode prosseguir em pesquisas futuras, o que pode ou não resultar na possibilidade de concordância entre avaliações desse nível. O objetivo (a) foi atingido. Já o objetivo (b) foi atingido em parte: a explicitação, sistematização e validação das categorias do nível semântico-lexical iniciaram-se nesta pesquisa, e podem continuar em estudos futuros. Esta pesquisa pode ser vista como contribuição tanto para área de tradução de poesia, quanto para a Linguística Computacional. Quanto à primeira, a anotação prevê interpretações e tomadas de decisão, evidenciando, assim, as possíveis interpretações e decisões tomadas durante o processo de tradução. E em relação à segunda, o desenvolvimento de uma ferramenta para anotação de poemas, e de uma métrica para avaliação de traduções de poesia, utilizando as categorias presentes nesta tese, poderia ocorrer através de uma parceria com a Engenharia Computacional.

\section{Palavras-chave}

Tradução de poesia; prosódia poética comparada; avaliação; Linguística Computacional; anotação. 


\section{Abstract}

Menezes, Juliana Cunha; Britto, Paulo Henriques (Advisor); de Freitas, Maria Cláudia (Co-advisor). Evaluation of poetry translation: annotation in the search for consensus. Rio de Janeiro, 2017, 196p. Tese de Doutorado Departamento de Letras, Pontifícia Universidade Católica do Rio de Janeiro.

This study, which can be included in the post-structuralist field, has as its hypothesis the possibility of establishing categories capable of making the following kind of evaluation possible: minimally consensual evaluations of poetry translations. Therefore, when taking into account two or more translations of a poem, submitted to two or more evaluators who adopt uniform categories of analysis, their evaluations, though not identical, will have some relevant aspects in common. The search for consensus is carried out through annotation, one of the activities of Computational Linguistics, which identify and classify a certain linguistic phenomenon, using labels, tags, categories, in a given corpus, so as to achieve a certain goal. The aims of this dissertation are (a) to provide tools for evaluating translations of poems in a minimally consensual way;and (b) to define, systematize and validate the categories of the semantic-lexical level, and to describe and confirm the categories of the formal level (metric and rhymic levels) and of the poetic field of sound resources, so that they all can be used to support minimally consensual evaluations of poetry translation. The research consists of three steps. In the first, annotation is used as a methodology in the search of consensus. In this step, annotations of poems and their translations were made by different annotators. By comparing these annotations searching for consensus, categories were confirmed/validated or reformulated. The consensus allows confirmation and validation, but absence of consensus suggests reformulations and refinements. In the second step, Britto's methodology, with some additional observations, was used to analyse the results from the first step. This methodology aims at verifying whether the most relevant aspects of the formal and semantic-lexical levels and of the poetic field of sound resources (alliterations, assonances, and the like) of the poems have been re-created in the translations. And in the third step, the results of the second one are used in order to produce resources for a possible evaluation of poetry translations: among two translations of the sonnet 130 by Shakespeare, which one would be the most faithful. The hypothesis was proved concerning the formal level and the poetic field of sound resources, but wasn't proved regarding the semantic-lexical 
level. The validation of categories of the semantic-lexical level can go on in future researches, which may or may not result in the possibility of agreement among evaluations of this level. Aim (a) was achieved. And aim (b) was partially achieved: the definition, systematization and validation of the categories of the semantic-lexical level started in this research, and can go on in future studies. This research can be seen as a contribution not only to the field of poetry translation, but also to Computational Linguistics. Regarding the first, annotation requires interpretations and decision-making processes, thus highlighting the possible interpretations and decision-making processes used during translation. And, concerning the second, the development of a tool for poem annotation, and of a metric for evaluation of poetry translation, using the categories present in this dissertation, may be achieved through a partnership with Computer Engineering.

\section{Keywords}

Poetry translation; comparative poetic prosody; evaluation; Computational Linguistics; annotation. 


\section{Sumário}

1 Introdução 14

1.1 Objetivos 16

1.2 Hipótese 16

$\begin{array}{ll}1.3 \text { A organização da tese } & 17\end{array}$

2 Enquadramento teórico 18

$\begin{array}{ll}2.1 \text { A perspectiva pós-estruturalista } & 18\end{array}$

2.2 Avaliação de tradução no logocentrismo 21

2.3 Avaliação de tradução de poesia no pós-estruturalismo 23

2.3.1 Fidelidade ao original: correspondência formal e funcional 25

2.4 Diálogos com a Linguística Computacional 28

3 Categorias para análise e avaliação de tradução de poesia 32

3.1 Nível semântico-lexical: categorias SL 32

3.1.1 Categorias SL1 33

3.1.2 Categorias SL2 35

3.1.3 Categorias SL3 37

3.1.4 Categorias SL4 39

$\begin{array}{ll}\text { 3.2 Nível formal: categorias F } & 41\end{array}$

3.3 Plano de recursos sonoros: categorias RS 43

3.4 Guias $\quad 44$

4 Metodologia e procedimentos da pesquisa: três etapas 46

4.1 Ferramentas de anotação: recursos do Word 46

$\begin{array}{ll}4.2 \text { Estudos de caso } & 50\end{array}$ 
4.2.2 Ivo Barroso 52

4.2.3 Jorge Wanderley 52

4.3 Anotadores 53

4.3.1 JC 54

4.3.2 AD 54

4.3.3 EF 54

4.3.4 AS 55

4.3.5 MM 55

4.4 Primeira etapa 55

4.4.1 Procedimentos iniciais: anotações feitas por cada anotador 55

4.4.2 Procedimentos finais: a comparação das anotações 56

4.4.3 A primeira etapa em relação ao estudo de caso 1

4.4.4 Após a reformulação das categorias SL1 58

4.4.5 A primeira etapa em relação ao estudo de caso 2 : após a reformulação das categorias SL2 58

4.5 Segunda etapa 59

4.5.1 Procedimentos da segunda etapa 59

4.5.2 A segunda etapa em relação ao estudo de caso 1:
após a reformulação das categorias SL3

4.5.3 A segunda etapa em relação ao estudo de caso 2: após a reformulação das categorias SL3 61

4.6 Terceira etapa 62

4.6.1 Procedimentos da terceira etapa 62

5 Resultados da primeira etapa $\quad 64$

$\begin{array}{ll}5.1 \text { Resultados A1 } & 64\end{array}$

5.1.1 Anotação feita por JC 64

5.1.2 Anotação feita por AD 65

5.1.3 Comparação das anotações 66 
$\begin{array}{ll}\text { 5.2 Resultados A2 } & 69\end{array}$

5.2.1 Anotação feita por JC 69

5.2.2 Anotação feita por EF 70

$\begin{array}{ll}\text { 5.2.3 Comparação das anotações } & 71\end{array}$

$\begin{array}{ll}\text { 5.2.4 Discussão dos resultados } & 74\end{array}$

$\begin{array}{ll}\text { 5.3 Resultados B } & 75\end{array}$

5.3.1 Anotação feita por JC 75

$\begin{array}{ll}\text { 5.3.2 Anotação feita por AD } & 77\end{array}$

5.3.3 Anotação feita por EF 78

5.3.4 Comparação das anotações e discussão dos resultados 79

5.4 Resultados C

5.4.1 Anotação feita por JC 81

5.4.2 Anotação feita por AD 82

5.4.3 Anotação feita por EF 83

5.4.4 Comparação das anotações e discussão dos resultados 84

5.5 Resultados D 85

5.5.1 Anotação feita por JC 85

5.5.2 Anotação feita por AS 86

5.5.3 Anotação feita por MM 87

5.5.4 Comparação das anotações 88

$\begin{array}{ll}\text { 5.5.5 Discussão dos resultados } & 91\end{array}$

5.6 Resultados E 95

5.6.1 Anotação feita por JC 95

5.6.2 Anotação feita por AS 96

$\begin{array}{ll}\text { 5.6.3 Anotação feita por MM } & 97\end{array}$

5.6.4 Comparação das anotações e discussão dos resultados 99 
5.7 Resultados F 99

5.7.1 Anotação feita por JC 99

$\begin{array}{ll}\text { 5.7.2 Anotação feita por AS } & 101\end{array}$

$\begin{array}{ll}\text { 5.7.3 Anotação feita por MM } & 102\end{array}$

5.7.4 Comparação das anotações e discussão dos resultados 102

6 Resultados da segunda etapa 104

$\begin{array}{ll}\text { 6.1 Resultados } \mathrm{G} & 104\end{array}$

6.1.1 Estudo de caso 1: gabarito do nível semântico-lexical 104

6.1.2 Relação entre o nível formal e as categorias do nível semântico-lexical

6.2 Resultados H 110

6.2.1 Estudo de caso 1: gabarito do nível formal 110

6.2.2 Aspectos do nível formal 112

6.2.3 Articulação de aspectos do nível formal com o nível semântico-lexical

112

$\begin{array}{ll}6.3 \text { Resultados I } & 114\end{array}$

6.3.1 Estudo de caso 1: gabarito do plano de recursos sonoros 114

6.3.2 Possíveis relações entre o plano de recursos sonoros e as categorias do nível semântico-lexical, com base nos Resultados $\mathrm{G}$

6.3.3 Articulação de aspectos do plano de recursos sonoros com o nível semântico-lexical

6.4 Resultados J

6.4.1 Estudo de caso 2: gabarito do nível semântico-lexical 118

6.4.2 Relação entre o nível formal e as categorias do nível semântico-lexical

$\begin{array}{ll}\text { 6.5 Resultados L } & 125\end{array}$

6.5.1 Estudo de caso 2: gabarito do nível formal 125

$\begin{array}{ll}\text { 6.5.2 Aspectos do nível formal } & 127\end{array}$

$\begin{array}{lr}\text { 6.5.3 Articulação de aspectos do nível formal } & 127 \\ \text { com o nível semântico-lexical } & 127\end{array}$ 
6.6 Resultados M 129

6.6.1 Estudo de caso 2: gabarito do plano de recursos sonoros 129

6.6.2 Possíveis relações entre o plano de recursos sonoros e as categorias do nível semântico-lexical, com base nos Resultados $\mathrm{J}$

6.6.3 Articulação de aspectos do plano de recursos sonoros com o nível semântico-lexical

7 Resultados da terceira etapa

135

7.1 Tabela GJ : comparação dos resultados G e J 135

7.2 Tabela HL: comparação dos resultados H e L 135

7.3 Tabela IM: comparação dos resultados I e M 136

$\begin{array}{ll}7.4 \text { Discussão dos resultados } & 137\end{array}$

8 Considerações finais

139

9 Referências bibliográficas

143

10 Anexos

10.1 Anexos A: estudos de caso

$\begin{array}{ll}\text { 10.1.1 Estudo de caso } 1 & 147\end{array}$

10.1.2 Estudo de caso 2

10.2 Anexos B: guias

10.2.1 Guia SL1

10.2.2 Guia SL2

10.2.3 Guia SL3

10.2.4 Guia SL4

10.2.5 Guia F 


\section{Introdução}

A questão da tradução de poesia vem sendo muito discutida na academia. Há estudiosos que não acreditam nela pois, para eles, cada poema tem sua essência, que jamais poderia ser transmitida para outra língua:

Um poema lírico é um ser vivo, de uma vida furtiva que reside no arranjo das palavras; não se transporta essa vida para um corpo estranho. Eu lia uma tradução russa muito exata e aceitável das Noites de Musset, e ela me dava o mesmo prazer que pode produzir o cadáver de uma bela criatura. A Alma tinha desertado, o aroma que constitui todo o valor dessas sílabas evaporara-se. (VOGÜE apud LARANJEIRA, 1993, p. 25)

Partidários dessa visão encaram o poema como uma forma que contém significados intrínsecos a ela e, por isso, se o idioma muda, tais sentidos se perdem.

Existem teóricos que acreditam na tradução de poesia. Mário Laranjeira, por exemplo, rejeita as ideias expostas acima. Segundo ele, no poema, a interação dos significantes gera significados, e esse processo é denominado de significância. Para esse autor, é possível traduzir um poema produzindo, na tradução, "uma significância correlata à do poema original." (LARANJEIRA, 1993, p. 30, grifo nosso). Um outro escritor que defende ideias semelhantes às de Laranjeira é Paulo Henriques Britto. De acordo com ele, o tradutor pode "recriar, utilizando, os recursos da língua-meta, os efeitos de sentido e forma do original - ou, ao menos, uma boa parte deles" (BRITTO, 2002, p. 54, grifos nossos). A significância de Laranjeira pode ser encarada como análoga ao processo de recriar os efeitos de sentido e forma do original de Britto.

Para os que defendem a intradutibilidade da poesia, a avaliação de uma tradução de poesia não faria sentido. Sob esse ponto de vista, todas as traduções seriam inválidas. Já se adotarmos as visões de Laranjeira e Britto, podemos dizer que a avaliação de traduções é possível. Para fazermos essa avaliação, teríamos que comparar a tradução com o original, verificando se a significância - os efeitos de sentido e forma do original - foram recriados na tradução. 
Mesmo entre os acadêmicos que acreditam na avaliação desse tipo de tradução, podemos apontar divergências. Discutirei brevemente as ideias de Rosemary Arrojo e de Britto sobre esse tema. Para Arrojo, quando nos propomos a avaliar traduções de poesia,"Inevitavelmente [...] aceitaremos e celebraremos aquelas traduções que julgamos "fiéis" às nossas próprias concepções textuais e teóricas e rejeitaremos aquelas de cujos pressupostos não compartilhamos" (ARROJO, 2002, p. 45). Tal autora tende a focar seus argumentos principalmente na subjetividade do avaliador. Já para Britto (2006b), é possível fazermos avaliações baseando-nos em aspectos significativos de cada nível e plano das traduções - nível formal, semântico-lexical e plano de recursos sonoros - sobre os quais há um certo grau de consenso entre estudiosos da área de tradução de poesia.

Britto, a fim de justificar suas opiniões acerca de traduções de poesia, utiliza certas categorias para análise e avaliação de traduções. Assumimos que essas categorias utilizadas por ele, individualmente, poderiam ser alvo de um processo que almeja, em última instância, explicitá-las de forma clara o suficiente a ponto de garantir uma concordância quando da sua aplicação a um mesmo objeto (tradução de poesia), por estudiosos diferentes. A ideia seria, então, explicitar categorias implícitas.

Esta pesquisa acredita em avaliações minimamente consensuais de traduções de poesia.Creio que podemos nos valer de determinadas categorias, compartilháveis entre estudiosos interessados na área, para dizermos, analisando traduções de um mesmo original, comparando-as com ele, qual seria a mais fiel a esse original. A visão sobre fidelidade na qual acredito é aquela adotada por Britto, e está estreitamente ligada à correspondência e à perda: "quanto maior a correspondência ponto a ponto entre os componentes de um dado elemento do original e os componentes da contraparte na tradução, menor terá sido a perda" (BRITTO, 2002, p. 65-66), e mais fiel ao original será a tradução. A questão da fidelidade será novamente abordada no capítulo Enquadramento teórico, subcapítulo Fidelidade ao original: correspondência formal e funcional. 


\section{1}

\section{Objetivos}

Os objetivos desta tese são (a) fornecer, aos interessados em tradução de poesia, insumos para se poder avaliar, de forma minimamente consensual, traduções de poemas; e (b) explicitar, sistematizar e validar categorias do nível semântico-lexical, e descrever e confirmar categorias do nível formal (níveis métrico e rimático) e do plano de recursos sonoros, a fim de que possam ser usadas para embasar avaliações minimamente consensuais de traduções de poesia.

Não tenho como objetivo avaliar traduções de poesia, e sim verificar até que ponto é possível estabelecer as categorias mencionadas no parágrafo anterior.

\section{2}

\section{Hipótese}

Acredito ser possível se estabelecerem categorias capazes de instrumentalizar avaliações minimamente consensuais de traduções de poesia. Assim, dadas duas ou mais traduções de um poema, submetidas a dois ou mais avaliadores que adotem categorias uniformes de análise, suas avaliações, ainda que não idênticas, terão em comum alguns pontos relevantes.

Tais aspectos significativos vão variar de acordo com o poema original: cada um apresenta características cuja reprodução na tradução julgamos ser de maior importância, quando comparadas com outras. Essa hierarquia, por sua vez, pode variar segundo cada estudioso que se propõe a avaliar traduções de um poema. Aqueles cuja subjetividade for permeada pelos mesmos pressupostos teóricos provavelmente irão considerar os mesmos pontos como relevantes. Assim, a consensualidade pode ser observada a partir de certos aspectos dos originais e das traduções acerca dos quais existe algum grau de concordância entre interessados na área de tradução de poesia. 


\section{3}

\section{A organização da tese}

No capítulo 2, trato do enquadramento teórico que norteou esta pesquisa; no capítulo 3,explicito, sistematizo e descrevo as categorias para análise e avaliação de tradução de poesia; no capítulo 4, apresento a metodologia e os procedimentos da pesquisa; no capítulo 5, apresento e discuto os resultados da primeira etapa; no capítulo 6, apresento e discuto os resultados da segunda etapa; no capítulo 7, apresento e discuto os resultados da terceira etapa; no capítulo 8, teço considerações finais; no capítulo 9, apresento as referências bibliográficas; e no capítulo 10, apresento os anexos, que são compostos pelos estudos de caso 1 e 2, e pelos guias SL1, SL2, SL3, SL4, F e RS. 


\section{Enquadramento teórico}

Esta tese assume uma pespectiva pós-estruturalista no diálogo entre duas áreas, a princípio, tão distantes: Avaliação de tradução de poesia e Linguística Computacional. Nos cinco subcapítulos seguintes, tratarei de questões referentes a cada uma delas, e evidenciarei aproximações.

\section{1}

\section{A perspectiva pós-estruturalista}

O pós-estruturalismo descontroi várias noções logocêntricas, tais como aquela de que cada texto apresenta significados estáveis e facilmente apreensíveis pelo leitor:

A possibilidade desse resgate de significados estáveis é pressuposta pela grande maioria do conhecimento produzido pelo homem ocidental e permeia, naturalmente, todas as nossas concepções clássicas de linguagem. (ARROJO, 2003a, p. 67)

Se cada texto já tivesse seus sentidos predeterminados, a avaliação de tradução apenas consideraria traduções fiéis aquelas que apresentassem total equivalência ${ }^{1}$ com a combinação de significados do texto original. A desconstrução dessa noção está bem viva em minha pesquisa. Não encaro o texto como um conjunto de sentidos preestabelecidos: os variados significados só passam a existir através de diferentes leituras. Porém, se levarmos esta ideia às últimas consequências, sob uma ótica pósestruturalista radical, a avaliação de tradução consideraria qualquer tradução fiel ao original, pois cada uma seria correspondente ${ }^{2}$ a uma determinada leitura do original. No entanto, creio em uma visão intermediária, não radical: é possível haver diversas leituras

\footnotetext{
1 A questão da equivalência será abordada neste capítulo, subcapítulo Fidelidade ao original: correspondência formal e funcional.

${ }^{2}$ A questão da correspondência será abordada neste capítulo, subcapítulo Fidelidade ao original: correspondência formal e funcional.
} 
de um mesmo texto e traduções para ele, porém, podemos determinar qual dessas traduções é a mais fiel, de acordo com determinados critérios. Tal noção está relacionada à "ilusão do significado atingido" (GRIGOLETTO, 2003a, p. 31). Acerca de tal ilusão, Britto explica que

não é possível determinar com exatidão qual o significado único e preciso de um determinado texto, nem tampouco identificar um tal significado com a intenção consciente do autor. E é evidente que é ingenuidade acreditar que o significado é uma entidade abstrata que pode ser destacada dos outros elementos do texto, como o estilo. O problema, porém, é que, para a grande maioria dos fins práticos que envolvem a utilização de textos, só podemos agir se adotarmos certos pressupostos, aproximações que, embora não correspondam à realidade dos fatos, são imprescindíveis. Temos que agir como se os autores fossem sujeitos conscientes e seus textos exprimissem um significado estável que corresponde a suas intenções conscientes; do mesmo modo, quando trabalhamos com traduções de seus textos, temos que agir como se as traduções deses textos fossem equivalentes aos originais, podendo aquelas serem usadas como substitutos destes. (BRITTO, 2003, p. 45, grifo do autor)

A adoção de tais concepções é fundamental para se adotar a visão pósestruturalista não radical exposta anteriormente neste subcapítulo. É necessário estebelecermos certos significados para um texto, a fim de que possamos traduzi-lo e, também, para que possamos avaliar suas traduções.

Os significados das palavras também podem ser discutidos sob um viés pósestruturalista radical: poderíamos pensar que qualquer sentido seria válido para qualquer palavra, resultando, assim, num caos referente à comunicação oral e escrita. Todavia, para que isso não aconteça, ancoramos determinados sentidos em certas palavras. Além disso, temos consciência de que, dependendo do viés adotado - logocentrismo ou pósestruturalismo não radical, por exemplo - o mesmo termo pode ser encarado de modos diferentes. Assim, apresento, a seguir, dois glossários: um com a visão acerca de alguns termos sob a ótica logocêntrica, e outro com a visão acerca dos mesmos termos sob a ótica pós-estruturalista não radical. Quando esta tese tratar de avaliação de tradução no logocentrismo, o Glossário 1 deve ser levado em conta; e quando tratar de avaliação de tradução de poesia no pós-estruturalismo não radical, o Glossário 2 deve ser levado em consideração.

\section{Glossário 1}

\begin{tabular}{|l|l|}
\hline Consensualidade & Concordância \\
\hline Objetividade & Julgamento com o máximo de isenção e imparcialidade \\
\hline
\end{tabular}




\begin{tabular}{|l|l|}
\hline Subjetividade & Julgamento individual, pessoal \\
\hline Intenção do autor & Temos acesso a ela: os significados estáveis do texto são fruto dela \\
\hline Equivalência & Qualidade do que é idêntico \\
\hline Fidelidade & $\begin{array}{l}\text { Equivalência entre os significados do texto traduzido e os do texto } \\
\text { original }\end{array}$ \\
\hline
\end{tabular}

\section{Glossário 2:}

\begin{tabular}{|c|c|}
\hline Consensualidade & Concordância entre estudiosos da área de tradução de poesia \\
\hline Objetividade & $\begin{array}{l}\text { Fruto da consensualidade entre estudiosos da área de tradução de } \\
\text { poesia }\end{array}$ \\
\hline Subjetividade & Julgamento individual, pessoal \\
\hline Intenção do autor & $\begin{array}{l}\text { Não temos acesso a ela: os significados do texto são fruto de } \\
\text { diversas leituras. No entanto, "Temos que agir como se os autores } \\
\text { fossem sujeitos conscientes e seus textos exprimissem um } \\
\text { significado estável que corresponde a suas intenções conscientes } \\
\text { [...]" (BRITTO, 2003, p. 45). Informação retirada deste subcapítulo. }\end{array}$ \\
\hline Fidelidade & $\begin{array}{l}\text { Está estreitamente ligada à correspondência e à perda: "quanto } \\
\text { maior a correspondência ponto a ponto entre os componentes de } \\
\text { um dado elemento do original e os componentes da contraparte na } \\
\text { tradução, menor terá sido a perda" (BRITTO, 2002, p. 65-66), e } \\
\text { mais fiel ao original será a tradução. Informação retirada do } \\
\text { capítulo Introdução. Tal questão é detalhada neste capítulo, } \\
\text { subcapítulo Fidelidade ao original: correspondência formal e } \\
\text { correspondência funcional. }\end{array}$ \\
\hline Equivalência & $\begin{array}{l}\text { Conceito substituído por correspondência: qualidade do que é } \\
\text { análogo. Mais informações neste capítulo, subcapítulo Fidelidade } \\
\text { ao original: correspondência formal e correspondência } \\
\text { funcional. }\end{array}$ \\
\hline
\end{tabular}




\section{2}

\section{Avaliação de tradução no logocentrismo}

Discutirei aqui as ideias de duas estudiosas que defendem avaliações mais objetivas de traduções em geral, sob a ótica logocêntrica: Katharina Reiss e Juliane House.

Reiss, em seu livro Translation Criticism - The Potentials \& Limitations (2000), propõe um modelo para avaliação de traduções em geral. Tal estudiosa acredita que

Um dos princípios mais importantes para tradutores é a fidelidade completa à intenção do autor. Somente através da comparação com texto-fonte podemos descobrir se essa fidelidade foi atingida, o quão bem a intenção do autor foi compreendida, como ela foi interpretada, e o quão bem ela foi expressa na língua de chegada. Uma avaliação que toma como base a língua de partida representa crítica que leva isso tudo em consideração.(REISS, 2000, p.16, tradução nossa ${ }^{3}$ ).

Nota-se, a partir da citação, a crença na noção logocêntrica de que temos acesso àintenção do autor. Quanto à avaliação de traduções, Reiss (2000), assim como eu, julga imprescindível a comparação da tradução com o original. A autora, em seu modelo, estabelece três categorias: a categoria literária (tipo de texto), a categoria linguística (elementos linguísticos) e a categoria pragmática (determinantes extralinguísticos). Sobre a primeira categoria, essa autora afirma que

Assim como o tradutor precisa saber a que tipo de texto pertence o original que ele pretende traduzir antes de começar a trabalhar nele, o avaliador também precisa saber a que tipo de texto pertence o original, a fim de evitar o uso de padrões inadequados para julgar a tradução. (ibidem)

De acordo com Reiss, o avaliador deve verificar se as características do tipo de texto dominante do original foram mantidas na tradução. A autora trata de quatro tipos de textos, com quatro focos diferentes: no conteúdo, na forma, no apelo e na fala escrita.

Acerca da segunda categoria, a escritora explica que

ela está relacionada a aspectos linguísticos e seus equivalentes na língua-alvo. O avaliador deve examinar em detalhes como o processo de tradução representou as peculiaridades linguísticas da língua-fonte na língua-alvo. (ibidem, p. 48, grifo da autora)

Segundo Reiss, ao verificar se as características linguísticas do original foram reproduzidas na tradução, o avaliador deve levar em conta as dimensões semântica, lexical, gramatical e estilística do original, assim como sua esfera pragmática.

\footnotetext{
${ }^{3}$ Todas as citações extraídas de obras em língua inglesa foram traduzidas por mim.
} 
Referindo-se à terceira categoria, Reiss argumenta que

$\mathrm{O}$ avaliador não deve esquecer que considerações acerca de equivalentes escolhidos para os elementos linguísticos do original serão insatisfatórias se os determinantes extralinguísticos, que afetam radicalmente tanto a forma do original quanto a versão na língua de chegada, não forem levados em conta. São eles que muitas vezes fazem toda a diferença na hora de decidir se um equivalente é a melhor opção ou apenas uma opção possível. (ibidem, p. 66-67)

Para Reiss, tais determinantes são muito relevantes em avaliações de traduções, pois eles estão relacionados a situações, fatos, momentos e lugares bem específicos, aos ouvintes, aos falantes e às implicações subjetivas envolvidas.

Apesar de toda essa tentativa de estabelecer categorias e critérios mais objetivos para avaliações de traduções, Reiss não ignora o fato de que julgamentos serão afetados pelas dimensões subjetivas de cada avaliador.

House, em seu livro A Model forTranslation Quality Assessment (1981), também sugere um modelo para avaliar traduções em geral. Segundo House, o principal critério para medir a qualidade de uma tradução, ao compará-la com o original, é o de equivalência, que está diretamente ligada à manutenção do significado no processo tradutório. Tal escritora acredita na noção logocêntrica da reprodução, por parte da tradução, do significado estável do texto original.

No modelo de House, esse significado apresenta três aspectos fundamentais: o aspecto semântico, o pragmático e o textual. Sobre o primeiro, House afirma que

consiste na relação de referência ou denotação, isto é, a relação entre os símbolos ou unidades linguísticas e seus referentes em algum mundo possível; "mundo possível" significando qualquer mundo que a mente humana seja capaz de construir. Essa definição leva em conta o fato de que, semanticamente, enunciados significativos ocorrem mesmo que os termos do enunciado não tenham referentes no mundo real, como, por exemplo, no caso da ficção científica. (HOUSE, 1981, p. 25)

Acerca do segundo aspecto, a autora explica que "ele refere-se à correlação entre unidades linguísticas e os usuários dessas unidades, em uma dada situação de comunicação" (ibidem, p. 27). Como tal aspecto considera o significado em situações concretas, para House, seria mais importante manter a equivalência pragmática do que a semântica. De acordo com essa autora, "Podemos, portanto, considerar uma tradução como, principalmente, uma reconstrução pragmática de seu texto-fonte" (ibidem, p. 28).

Sobre o terceiro aspecto, House argumenta que

Um texto é uma associação de sentenças em uma unidade maior. Várias relações de referências cotextuais acontecem no processo de constituição textual, como, por exemplo, [..] substituições, correferências, elipses, anáforas. Essas formas diferentes de constituição textual são responsáveis pelo significado textual que deve ser reproduzidode forma equivalente na tradução. (ibidem, p. 29) 
Segundo essa autora, a tradução deve ser equivalente ao original nesses três aspectos do significado. Mesmo com todo esse aparato que tem como meta avaliações mais objetivas de traduções, House leva em consideração a questão de que a subjetividade irá, sem dúvida, influenciar tal processo.

Apesar de tais autoras, em seus argumentos, adotarem noções logocêntricas, podemos apontar convergências entre algumas de suas ideias e aquelas que permeiam esta pesquisa, tais como a avaliação a partir da comparação entre a tradução e o original; a tentativa de sistematização de critérios e categorias de avaliação ${ }^{4}$; e a defesa de avaliações menos subjetivas de traduções, não ignorando suas limitações.

\section{3}

\section{Avaliação de tradução de poesia no pós-estruturalismo}

Quanto à discussão sobre avaliação de tradução de poesia no pós-estruturalismo, podemos destacar dois estudiosos: Arrojo e Britto. Acredito que aquela se insere no viés radical, e este, no não radical. Já falamos um pouco de ambos os autores no capítulo Introdução, e vamos aprofundar certas questões aqui.

Tanto Arrojo quanto Britto acreditam que não há significados estáveis no texto que possam ser interpretados e, assim, traduzidos para uma outra língua: "a tradução seria teórica e praticamente impossível se esperássemos dela uma tranferência de significados estáveis [...]" (ARROJO, 2002, p. 42). Ambos também creem que

[...] nossa tradução de qualquer texto, poético ou não, será fiel não ao texto "original", mas aquilo que consideramos ser o texto original, àquilo que consideramos constitui-lo, ou seja, à nossa interpretação do texto de partida, que será [...] sempre produto daquilo que somos, sentimos e pensamos. (ibidem, p. 44)

Nenhum dos dois estudiosos ignora as esferas subjetivas que permeiam as interpretações de um texto e, consequentemente, suas traduções. Quanto às considerações sobre as traduções do poema "Elegie XIX: Going to bed", de John Donne, feitas por Augusto de Campos e de Paulo Vizioli, ainda podemos destacar algumas ideias convergentes:

a tradução de um poema e a avaliação dessa tradução não poderão realizar-se fora de um ponto de vista, ou de uma perspectiva, ou sem a mediação de uma "interpretação". Portanto, a tradução de um poema, ou de qualquer outro texto, inevitavelmente será fiel

\footnotetext{
${ }^{4}$ Mais informações sobre essa sistematização de categorias em minha pesquisa podem ser encontradas no capítulo Categorias para análise e avaliação de tradução de poesia.
} 
à visão que o tradutor tem desse poema e, também, aos objetivos de sua tradução. [...](ARROJO, 1993, p. 24-25)

As noções de Arrojo, apresentadas até este ponto do presente subcapítulo, são semelhantes às de Britto. No entanto, algumas das visões desses autores, acerca de avaliação de tradução de poesia, divergem. Ainda sobre as traduções de Campos e Vizioli, a autora afirma que

Tanto Paulo Vizioli quanto Augusto de Campos são "fiéis" às suas concepções teóricas acerca de tradução e acerca da poesia de Donne, e, nesse sentido, tanto as traduções de um, como de outro, são legítimas e competentes.Inevitavelmente, as traduções de cada um deles agradarão aos leitores que, consciente ou inconscientemente, compartilharem de seus pressupostos, e desagradarão àqueles que [...] já foram seduzidos por pressupostos diferentes. (ARROJO, 1993, p. 24-25, grifo nosso)

O critério que Arrojo utiliza para avaliação de traduções de poesia tem principal suporte nos pressupostos adotados por cada avaliador. Britto não nega tal influência em nossos julgamentos, no entanto, ele apresenta uma visão alternativa:

ainda que não haja um consenso absoluto, e ainda que cada um de nós faça seus julgamentos com base em seus próprios pressupostos, é possível [...]fazer avaliações e tecer considerações em torno de traduções, fazendo referência a certas propriedades dos textos traduzidos com relação às quais há um certo grau de acordo entre [...] pessoas envolvidas nas atividade [sic] de traduzir.Dadas duas traduções de um mesmo texto, A e $B$, cotejem-se A e B com o original e uma com a outra, linha a linha, sílaba a sílaba, examinando e pesando as diferenças [...]. (BRITTO, 2006b, 252, grifo nosso)

De acordo com as ideias grifadas acima, Britto desenvolveu uma metodologia para avaliações mais objetivas de traduções de poesia, que pode ser encontrada em Britto (2002; 2006c). Sua metodologia apresenta os seguintes passos:identificar as características poeticamente significativas do poema original;atribuir uma prioridade a cada característica, dependendo da maior ou menor contribuição por ela dada ao efeito estético total do poema; e verificar, nas traduções, se foram recriadas as características tidas como as mais significativas das que podem efetivamente ser recriadas - ou seja, verificar se foram encontradas correspondências para elas. Portanto, a meta dessa metodologia é verificar se os aspectos mais relevantes dos níveis métrico, rimático, semântico-lexical e do plano de recursos sonoros - aliterações, assonâncias e recursos afins - dos poemas originais foram recriados nas traduções, segundo algum grau de consenso entre estudiosos. Tal metodologia avalia as traduções de acordo com o grau de fidelidade que elas mantêm com o original: quanto maior a correspondência com o poema original, levando-se em conta todos esses níveis e planos, mais fiel é a tradução. A questão da fidelidade será abordada com mais detalhes no próximo subcapítulo. 


\subsection{1}

\section{Fidelidade ao original: correspondência formal e funcional}

A distinção entre correspondência formal e correspondência funcional pode ser conectada “à que foi estabelecida por $\mathrm{Nida}^{5}$ entre 'equivalência formal' e 'equivalência dinâmica"” (BRITTO, 2006c, p. 3), respectivamente. Acerca dessas duas concepções de equivalência ${ }^{6}$ de Nida, Bezerra ${ }^{7}$ afirma que "a equivalência formal corresponde, no quadro mais amplo das teorias da tradução, às 'teorias tradicionais' concentradas no texto-fonte, enquanto a equivalência funcional/dinâmica se concentra no textoalvo"(BEZERRA, 2015, p. 244). Sobre a equivalência formal e a equivalência dinâmica, Bezerra argumenta que cada uma, respectivamente,

predomina nas versões mais tradicionais, que parcialmente em virtude disso também se caracterizam por uma linguagem mais arcaica, formal e erudita. Versões orientadas por esse princípio [...] procuram representar a língua original palavra por palavra na língua de destino. (ibidem, grifos do autor)

predomina em versões mais contemporâneas, em geral preocupadas com o uso de uma linguagem mais atualizada, em parte mais coloquial e mais fácil de ser entendida pelos leitores de hoje. (ibidem, p.245, grifos do autor)

Antes de partirmos para a discussão sobre correspondência formal e correspondência funcional, faz-se necessário discorrer sobre a diferença que Britto estabelece entre os conceitos de equivalência e de correspondência em tradução, levando em conta as visões de Nida, discutidas por Bezerra, acima:

Em primeiro lugar, a palavra "equivalência" supõe uma relação muito mais forte do que "correspondência": dizer que uma tradução é equivalente a um original é ir além do que enunciamos acima como "uma correspondência mais ou menos próxima entre ao menos algumas características importantes de A e de B". A tradução de um poema não é, em nenhum sentido estrito do termo, equivalente ao original; o máximo que se pode exigir de um poema traduzido é que ele capte algumas das características reconhecidas como

\footnotetext{
${ }^{5}$ Linguista que estudava a tradução de textos bíblicos.

${ }^{6}$ Trataremos aqui da equivalência e correspondência em tradução. Não abordaremos a questão da equivalência de que trata Ellis em: "as coisas que são agrupadas pelas categorias linguísticas são tratadas como se fossem equivalentes e que as razões para essa equivalência podem variar" (ELLIS, 1993, p. 35, grifo do autor). Essa equivalência aborda a prática de tratar coisas diferentes como iguais, ao as agruparmos em uma mesma categoria.

${ }^{7}$ Benedito Gomes Bezerraé professor adjunto da Universidade de Pernambuco, Campus Garanhuns, onde exerce a função de Coordenador do Programa de Mestrado Profissional em Letras em Rede Nacional PROFLETRAS/UPE e Professor Assistente da Universidade Católica de Pernambuco, atuando no Programa de Pós-Graduação em Ciências da Linguagem.
} 
importantes do poema original, e que seja lido como um poema na língua-meta. Em segundo lugar, Nida está preocupado exclusivamente com o significado do texto a ser traduzido (o texto bíblico), encarado como conteúdo semântico veiculado por uma forma, uma visão expressa através da conhecida analogia com um trem de carga, em que os significantes seriam os vagões e os significados a carga neles transportada. Em poesia, é claro, não podemos estabelecer uma diferença tão nítida entre forma e sentido, e o que é preciso reconstruir na tradução poética é uma totalidade textual integrada por sons, significados, imagens e até mesmo a disposição visual de símbolos gráficos sobre o papel. Portanto, a tradução de um poema é uma operação bem mais complexa do que a redistribuição de sentidos diversos por significantes diversos; os fatores que devem ser levados em conta são de toda ordem: formal, semântica, sintática, lexical, morfológica, fonética, prosódica,gráfica. (BRITTO, 2006c, p. 3)

Nida trata do texto bíblico, encarando-o como um conjunto de significantes que servem apenas para transmitir sentidos e, desse modo, mesmo quando o idioma muda, o conteúdo pode ser mantido idêntico, reproduzido de forma equivalente. Para Britto,quando tratamos de tradução de poesia, não podemos desconsiderar os efeitos produzidos pelos significantes do original e, assim, ao mudarmos os significantes, precisamos tentar reproduzir não somente os efeitos de sentido do original, como também os efeitos de forma,não de maneira equivalente, idêntica; mas sim correspondente, análoga. Ao analisarmos as visões de Nida quanto à equivalência, e as de Britto quanto à correspondência, notamos que aquela que se integra melhor a esta pesquisa é a de correspondência de Britto.

Discorreremos agora sobre correspondência formal e correspondência funcional em tradução de poesia. De acordo com a correspondência formal, a tradução e o poema original apresentam aspectos estruturantes muito similares. Assim como na equivalência formal de Nida, o foco é no texto-fonte. Segundo Britto,

pode-se defender a opção de traduzir para o português um soneto de Shakespeare em pentâmetros jâmbicos utilizando-se decassílabos heroicos argumentando que estruturalmente o decassílabo corresponde de modo razoável ao pentâmetro jâmbico. Afinal, o jambo tem duas sílabas, e num pentâmetro temos 2 × $5=10$ sílabas. (BRITTO, 2006c, p.2)

Segundo a correspondência funcional, a tradução pode ter características estruturantes bem diferentes daquelas do original, no entanto, a forma do poema traduzido deve possuir conotações na língua e literatura-alvo semelhantes àquelas do poema original na língua e literatura-fonte. Assim como na equivalência dinâmica de Nida, o foco é no texto-alvo. Um caso em que alguns tradutores optam pela correspondência funcional são as traduções de poemas de Emily Dickinson. Tratemos, por exemplo, da tradução do poema 870 dessa escritora. De acordo com Britto, 
O poema em questão utiliza o chamado "metro comum", um dos três "metros de balada" do inglês, em que o primeiro e o terceiro versos têm quatro pés, o segundo e o quarto têm três. Se tentarmos encontrar uma forma estruturalmente equivalente em português, raciocinando de modo análogo ao que nos levou a concluir que o decassílabo era um bom equivalente formal do pentâmetro jâmbico, utilizaremos uma estrofe em que os versos ímpares têm oito sílabas e os pares têm seis. Que essa estratégia pode dar bons frutos é inegável; afinal, a importação de formas estrangeiras é prática mais do que abonada pela tradição: o soneto, a sextina, a oitava-rima, a terça rima, o haiku, o gazel e muitas outras foram trazidas para o português de outras tradições poéticas. Por outro lado, seria possível argumentar que a forma do metro de balada tem uma determinada conotação. Por ser característico da poesia popular de língua inglesa, não só da balada propriamente dita com [sic] também das nursery rhymes(poesia infantil) e dos hinos de igreja, o metro de balada conota singeleza,espontaneidade, naturalidade, e o tradutor pode desejar preservar essas conotações em suas versões. Nesse caso, ele poderá recorrer a uma correspondência funcional: uma forma que, embora estruturalmente diversa, possua essas mesmas conotações, ou conotações próximas, na língua-meta. No português, a tradicional redondilha maior seria talvez uma forma com as conotações desejadas; assim, o tradutor poderia verter o poema 870 de Dickinson dessa forma para captar algo da aura de simplicidade do original. (ibidem)

A fim de decidir entre uma correspondência formal ou funcional, o tradutor deve analisar o poema a ser traduzido, para que possa verificar se as duas são possíveis, ou se terá de optar por uma ou outra. Por exemplo, um caso de tradução que pode manter ambas as correspondências com o original é

a tradução do inglês de um soneto em pentâmetro jâmbico por um soneto em português em decassílabos. O soneto é uma forma poética que tem mais ou menos as mesmas conotações nos dois sistemas literários ${ }^{8}$; o pentâmetro jâmbico, o metro mais usado no soneto inglês, tem dez sílabas, tal como o decassílabo português, que é o metro típico do soneto português. (ibidem, p. 12)

Já no caso das traduções de Dickinson, a opção entre uma correspondência formal ou funcional deve ser feita:

Ou bem traduzimos um poema que alterna versos de quatro pés por um que também alterne versos mais longos e versos mais curtos - uma correspondência puramente formal, já que esse tipo de metro não é comum em português — ou bem adotamos uma forma, como a redondilha menor, que tenha as conotações de simplicidade e folksiness da balada inglesa, mesmo sem corresponder à forma do original. (ibidem, p. 13)

Quanto à tradução do metro de balada utilizado por Dickinson, ao optar por manter a correspondência funcional, o tradutor poderá reproduzir o contraste entre a complexidade do plano do sentido e a simplicidade da forma poética, característica fundamental em Dickinson.

\footnotetext{
${ }^{8}$ Tradicionalmente, em todos os idiomas europeus, o soneto era uma forma nobre, que tratava do amor à maneira idealizada de Petrarca (século XIV). Já em Shakespeare isso começa a mudar (século XVI), tendo este escritor criticado e desconstruído idealizações típicas de Petrarca, introduzindo ironia à abordagem do amor. A partir do século XVIII, passou a ser possível utilizar o soneto para conotar quaisquer ideias.
} 
Creio que a fidelidade em tradução de poesia deve levar em conta as seguintes questões:

(a) a tradução deve priorizar reproduzir a forma poética do original: um soneto deve ser traduzido, em princípio, por um soneto, por exemplo.

(b) a tradução deve priorizar reproduzir os aspectos métricos, rimáticos e fonológicos que se articulam de modo mais evidente com o plano do sentido.

Em relação à reprodução desses aspectos métricos, rimáticos e fonológicos, a tradução deve:

(c) sempre que possível, manter as correspondências formal e funcional, desde que a manutenção de ambas possibilite ao tradutor priorizar a reprodução de aspectos métricos, rimáticos e fonológicos que se articulam de modo mais evidente com o plano do sentido; e

(d) quando não for possível manter as duas correspondências, a tradução deve optar por aquela que possibilite ao tradutor priorizar a reprodução de aspectos métricos, rimáticos e fonológicos que se articulam de modo mais evidente com o plano do sentido.

Nos estudos de caso desta tese, temos um soneto em pentâmetros jâmbicos traduzido por dois sonetos em decassílabos. Como ambas as correspondências são mantidas, levarei em conta somente as questões (a) e (b) nos procedimentos da segunda etapa desta pesquisa ${ }^{9}$; não considerarei as questões (c) e (d), que tratam do contraponto entre correspondência formal e funcional.

\section{4}

\section{Diálogos com a Linguística Computacional}

\section{A Linguística Computacional (LC) é}

é uma área aplicada, que se dedica à resolução de tarefas que envolvem a linguagem e que tem, como um de seus interesses, o desenvolvimento de ferramentas capazes de

\footnotetext{
${ }^{9}$ Mais informações quanto aos procedimentos da segunda etapa da pesquisa podem ser encontradas no subcapítulo Procedimentos da segunda etapa, em Segunda etapa, no capítulo Metodologia e procedimentos da pesquisa: três etapas.
} 
processar o texto, como lematizadores, analisadores morfossintáticos e semânticos. (FREITAS, 2015, p. 45)

Uma das atividades da LC é a anotação, que consiste em identificar e classificar um certo fenômeno linguístico, utilizando rótulos, etiquetas, categorias, em um determinado corpus para, assim, atingirmos um determinado objetivo.Um corpus pode ser definido como "um corpo de material linguístico existente em forma eletrônica, e que pode ser processado pelo computador para pesquisas linguísticas e engenharia linguística, por exemplo" (LEECH, 1997, p.1). Segundo Leech, a anotação de um corpus é

a prática de adicionar informação interpretativa, linguística a um corpus eletrônico de dados linguísticos falados e / ou escritos. "Anotação" também pode se referir ao produto final desse processo: os símbolos linguísticos que são anexados, ligados, ou intercalados à representação eletrônica do material linguístico em si. (LEECH, 1997, p.2, grifos do autor)

Ao dizermos que a anotação é "interpretativa", assumimos que ela, pelo menos em algum grau, “éo produto da compreensão do texto pela mente humana. Não há um jeito totalmente objetivo, mecânico, de decidir que etiqueta ou etiquetas devam ser aplicados a um dado fenômeno linguístico [...]" (LEECH, 1997, p. 2).

A anotação nada mais é que uma categorização. Segundo Ellis, categorização é “o aspecto mais fundamental da linguagem [...] e é a categorização, não a comunicação, que é a função mais importante da linguagem, que precede todas as outras" (ELLIS, 1993, p. 27). Para Ellis, as línguas são categorizações pois simplificam a complexidade das experiências, reduzindo a quantidade infinita a um conjunto finito de categorias - a um conjunto finito de palavras. Podemos encontrar uma ideia semelhante em obras de Nietzsche (1873/2009):

Denominamos um homem "honesto"; por que ele agiu hoje tão honestamente? perguntamos. Nossa resposta costuma ser: por causa de sua honestidade. A honestidade! [...] O certo é que não sabemos nada de uma qualidade essencial, que se chamasse "a honestidade", mas sabemos, isso sim, de numerosas ações individualizadas, portanto desiguais, que igualamos pelo abandono do desigual e designamos, agora, como ações honestas; por fim, formulamos a partir delas uma qualitas occulta com o nome "a honestidade". (NIETZSCHE, 1873 /2009, p. 48, grifo do autor)

De acordo com Ellis, as categorias são construídas em função de nossos interesses:

as categorias linguísticas são, primeiramente, o reflexo dos objetivos coletivos dos falantes, e não os reflexos diretos da estrutura do mundo. Em outras palavras, a equivalência criada pelas categorias de uma língua é funcional: aquelas coisas incluídas numa categoria podem ser e são tratadas como equivalentes em função dos interesses envolvidos na construção dessa categoria, apesar de não serem idênticas. Reciprocamente, o que é excluído de uma categoria é tratado como diferente apesar de algumas coisas excluídas apresentarem mais semelhanças com alguns membros da 
categoria do que esses mesmos membros apresentam em relação a muitos outros membros da categoria. Por exemplo, na grande cadeia de dialetos de língua românicas, que vai do nordeste até o sudeste europeu, um dialeto do francês falado próximo à fronteira da Itália poderia ser (especialmente antes dos efeitos da padronização serem sentidos) mais parecido com o dialeto do italiano falado do outro lado da fronteira do que com o seu respectivo idioma padrão; mesmo assim, tais dialetos ainda são categorizados como "francês" e "italiano". (ELLIS, 1993, p. 34).

Ellis complementa tal ideia afirmando que, como nossos interesses variam, nossas categorias são fluidas, instáveis: "as coisas que são agrupadas pelas categorias linguísticas são tratadas como se fossem equivalentes e que as razões para essa equivalência podem variar" (ELLIS, 1993, p. 35, grifo do autor). Para os objetivos da minha pesquisa, agrupei rimas diferentes na categoria RIMA, sílabas diferentes na categoria SÍLABA, pés diferentes na categoria PÉS, e símbolos diferentes para escansão na categoria SÍMBOLOS PARA ESCANSÃO (nível formal); omissões variadas na categoria OMISSÃO, alterações semânticas variadas na categoria ALTERAÇÃO SEMÂNTICA; e acréscimos variados na categoria ACRÉSCIMO (nível semânticolexical); e aliterações diversas na categoria ALITERAÇÕES, assonâncias diversas na categoria ASSONÂNCIAS, rimas internas diversas na categoria RIMAS INTERNAS, e repetições diversas diferenciadas na categoria REPETIÇÕES DIVERSAS (plano de recursos sonoros). Somente assim, igualando o não igual, pude dar conta da variedade de características dos níveis e plano poéticos dos estudos de caso. ${ }^{10}$

A anotação, tanto na LC quanto na tradução de poesia, pode ser um recurso para se fazer avaliações. Na LC, a anotação é geralmente usada para verificar o grau de acerto de um sistema com relação a uma determinada tarefa. Uma das maneiras de se avaliar um sistema é comparando o seu resultado com o de um gabarito (também chamado de golden collection). A criação de gabaritos, na Linguística Computacional, é um trabalho essencialmente linguístico e moroso: o gabarito representa o desempenho humano, e é em comparação a ele que os sistemas deverão ser comparados. A criação desses gabaritos, frequentemente, é feita por meio da tarefa de anotação. Na tradução de poesia, quando temos duas traduções de um mesmo original, podemos elaborar categorias para anotar o original e as traduções, a fim de se fazer possíveis avaliações: entre as duas traduções, verificar qual seria a mais fiel ao original.

${ }^{10}$ Mais informações sobre as categorias e os estudos de caso podem ser encontradas no capítulo Categorias para análise e avaliação de tradução de poesia; e no capítulo Metodologia e procedimentos da pesquisa: três etapas, subcapítulo Estudos de caso, respectivamente. 
Tais recursos de avaliações, na LC e na tradução de poesia, baseiam-se no consenso. Na LC, ao compararmos o resultado do sistema com o de um gabarito, verificamos o quanto esse resultado coincide com o gabarito. E na tradução de poesia, ao compararmos as anotações do original e das traduções, feitas por diferentes estudiosos, verificamos o grau de coincidência entre as anotações. Tanto em uma área quanto na outra, apesar de usarmos categorias que consideramos bastante precisas e delimitadas, observamos, através da anotação, que "sempre que traçamos uma linha divisória entre duas categorias há uma zona cinzenta entre elas, e haverá casos que não se enquadram perfeitamente nem numa nem na outra" (BRITTO, 2012, p.29). Os limites entre as categorias podem parecer, a princípio, bem claros, porém, ao anotarmos, deparamo-nos com a fluidez dessas fronteiras.

Cada anotação tem seu objetivo específico e, segundo Leech (1997), há uma série de decisões que precisam ser tomadas quando anotamos um corpus, e são norteadas pelos nossos interesses, pelos objetivos da anotação. A tomada de decisão é constante na anotação, o que evidencia determinados aspectos linguísticos inerentes à imprecisão das categorias, utilizadas para estabilizar um dado fenômeno. Portanto, a anotação pode nos ajudar a investigar a língua, porque lida, o tempo todo, com as “zonas cinzentas” da linguagem natural. Dessa forma, nesta pesquisa,

entendemos a anotação como uma forma de estudar a língua, e não apenas como uma atividade mecânica capaz de prover material para sistemas que processam a língua automaticamente. A anotação possibilita um estudo linguístico empírico, desenhado à maneira clássica, no qual se criam hipóteses (categorias/etiquetas provisórias) que serão verificadas durante a anotação. Nesse processo, as hipóteses iniciais podem ser confirmadas ou os dados podem levar à reformulação das categorias iniciais, e o processo recomeça. Enfatizamos a anotação como um procedimento que envolve interpretação, classificação e formalização do fenômeno em foco. (SANTOS et al, 2015, p.13-14)

$\mathrm{Na}$ presente tese de doutorado, anotações de poemas originais e de traduções serão feitas por diferentes estudiosos. Ao comparar essas anotações em busca de consenso, irei confirmar/validar ou reformular as categorias. O consenso permite confirmação e validação, já a falta dele abre espaço para reformulações e refinamentos. A anotação, além de me ajudar a atingir os objetivos da pesquisa, também deve salientar os limites da metalinguagem, pois todas as categorias que utilizarei nesta tese são palavras da linguagem natural: se as palavras são categorias fluidas da linguagem, as categorias utilizadas na presente pesquisa são categorias instáveis para análise e avaliação de tradução de poesia. 


\section{Categorias para análise e avaliação de tradução de poesia}

As categorias $F$ e categorias $R S$ (nível formal e plano de recursos sonoros, respectivamente)são baseadas em Chociay (1974), Tavares (2005), e Mattoso (2010), para os poemas traduzidos; e em Fraser (1977), Hollander (1989), e Fussell (1979), para os poemas originais. Tais categorias $F$ e $R S$ já são explicitadas e sistematizadas nas obras mencionadas no período anterior, assim, apenas as descrevo neste capítulo, nos subcapítulos Nível formal: categorias F e Plano de recursos sonoros: categorias RS, respectivamente.As categorias SL1, do nível semântico-lexical, criadas por Britto, podem ser encontradas na minha dissertação (MENEZES, 2012) ${ }^{11}$, e são explicitadas e sistematizadas,pela primeira vez, por mim, em Nível semântico-lexical: categorias SL, subcapítulo Categorias SL1. Podemos encontrar a explicitação e a sistematização das categorias SL2, SL3 e SL4 também em Nível semântico-lexical: categorias SL, subcapítulos Categorias SL2, Categorias SL3 e Categorias SL4, respectivamente.

As categorias $F$ e $R S$ já vêm sendo validadas e usadas há tempos por poetas, tradutores de poesia e críticos da tradução, tais como Britto, Haroldo de Campos e Laranjeira,para identificar e classificar aspectos formais e recursos sonoros de poemas, respectivamente. Assim, nesta tese, busco apenas confirmar a validade de tais categorias. Já as categorias SL são utilizadas somente por Britto e por mim, para identificar e classificar estratégias tradutórias referentes ao nível semântico-lexical, ao compararmos poemas originais e suas traduções. Dessa forma, tenho como objetivo validá-las, para que possam ser usadas por outros estudiosos, assim como ocorre com as categorias $F$ e $R S$.

\section{1}

\section{Nível semântico-lexical: categorias SL}

As categorias SL4 são fruto de reformulações das categorias SL3 que, por sua vez, são fruto das reformulações das categorias SL2 que, por sua vez, são fruto das

\footnotetext{
${ }^{11}$ Disponível em:

http://www2.dbd.puc-

rio.br/pergamum/biblioteca/php/mostrateses.php?open=1\&arqtese=1112728_2012_Indice.html
} 
reformulações das categorias SL1. Essas categorias SL4 foram utilizadas, na segunda etapa da pesquisa, para montar o gabarito dos estudos de caso 1 e 2, quanto ao nível semântico-lexical. Mais informações sobre isso podem ser encontradas no capítulo Metologia e procedimentos da pesquisa: três etapas, subcapítulo Segunda etapa.

\subsection{1}

\section{Categorias SL1}

\begin{tabular}{|c|c|}
\hline CATEGORIAS & EXPLICAÇÕES \\
\hline DUPLICAÇÃO & $\begin{array}{l}\text { É a estratégia que consiste em traduzir os elementos semânticos } \\
\text { presentes em um termo ou trecho de um dado verso ou dada } \\
\text { estrofe do original por dois termos ou trechos que expressam } \\
\text { esses mesmos elementos semânticos, no verso ou na estrofe } \\
\text { correspondente da tradução. }\end{array}$ \\
\hline ENXUGAMENTO & $\begin{array}{l}\text { É a estratégia que consiste em "enxugar", "resumir" os } \\
\text { elementos semânticos de um dado trecho do original em um } \\
\text { trecho correspondente na tradução. }\end{array}$ \\
\hline EXPLICITAÇÃO & $\begin{array}{l}\text { É a estratégia em que um trecho da tradução explicita elementos } \\
\text { semânticos implícitos no trecho correspondente do original. De } \\
\text { forma mais detalhada, podemos dizer que a EXPLICITAÇÃO } \\
\text { caracteriza-se pela presença, na tradução, de significantes que } \\
\text { apontam significados que podem ser inferidos a partir dos } \\
\text { significantes originais. }\end{array}$ \\
\hline DESLOCAMENTO & $\begin{array}{l}\text { É a estratégia de tradução que consiste em manter os elementos } \\
\text { semânticos de um termo ou trecho do original, porém } \\
\text { deslocando o termo ou trecho que se encontra em um dado } \\
\text { verso do original para um outro verso da tradução. O termo ou } \\
\text { trecho pode ser deslocado para um outro verso da mesma } \\
\text { estrofe, ou então para um outro verso da estrofe anterior ou } \\
\text { posterior. }\end{array}$ \\
\hline
\end{tabular}




\begin{tabular}{|c|l|}
\hline INVERSÃO & $\begin{array}{l}\text { É a estratégia de tradução que consiste em inverter a ordem das } \\
\text { palavras de um trecho do original no trecho correspondente da } \\
\text { tradução. }\end{array}$ \\
\hline $\begin{array}{l}\text { ALTERAÇÃO } \\
\text { SEMÂNTICA }\end{array}$ & $\begin{array}{l}\text { É a estratégia que consiste em traduzir um termo ou trecho do } \\
\text { original alterando seus elementos semânticos em um termo ou } \\
\text { trecho correspondente da tradução. }\end{array}$ \\
\hline OMISSÃO & $\begin{array}{l}\text { É a estratégia de tradução que consiste na omissão de elementos } \\
\text { semânticos presentes em um termo ou um trecho da estrofe do } \\
\text { original. }\end{array}$ \\
\hline ACRÉSCIMO & $\begin{array}{l}\text { É a estratégia de tradução que consiste no acréscimo de } \\
\text { elementos semânticos que não estão presentes na estrofe do } \\
\text { original, através de um termo ou um trecho da tradução. }\end{array}$ \\
\hline
\end{tabular}

Foram utilizadas por mim e por AD para anotarmos o estudo de caso 1, quanto ao nível semântico-lexical. Os resultados obtidos ao compararmos a minha anotação com a de AD levaram-me a repensar e reformular as categorias SL1. Percebi que era indesejável aquele grande número de categorias, porque, quanto o maior o número de categorias, maiores são as chances de haver discordância entre os anotadores. Notei, também, que as categorias DUPLICAÇÃO, ENXUGAMENTO, EXPLICITAÇÃO, DESLOCAMENTO e INVERSÃO ${ }^{12}$ eram desnecessárias, pois as categorias ALTERAÇÃO SEMÂNTICA, alteração de elementos semânticos; ACRÉSCIMO, acréscimo de elementos semânticos; e OMISSÃO, omissão de elementos semânticos, já apresentavam explicações que eram suficientes para anotações e futuras avaliações de traduções de poemas. Assim, resolvi abolir as categorias DUPLICAÇÃO, ENXUGAMENTO, EXPLICITAÇÃO, DESLOCAMENTO e INVERSÃO, mantendo somente ALTERAÇÃO SEMÂNTICA, ACRÉSCIMO e OMISSÃO, reformulando suas explicações e mudando seus exemplos. As duas primeiras, como foram as categorias que levaram a mais discordâncias, precisavam que suas explicações fossem

\footnotetext{
${ }^{12}$ Há sonetos de Shakespeare em que encontramos inversões sintáticas que se articulam de modo evidente com o plano do sentido, tais como o 116 (cf. BRITTO, 2008 a). Como não encontramos esse tipo de inversão no soneto 130, isso reforçou minha decisão de abolir a categoria INVERSÃO.
} 
modificadaspara evitar divergências nas próximas anotações. Já a última, mesmo sendo uma das categorias que levou a mais concordâncias, também foi alvo de refinamentos, porque, como suas explicações são, digamos, complementares às de ACRÉSCIMO OMISSÃO, omissão de elementos semânticos; ACRÉSCIMO, acréscimo de elementos semânticos - ao modificar as explicações de ACRÉSCIMO, o mais coerente a se fazer seria, também, refinar OMISSÃO. Dessa forma, mantive essas três categorias, tornando-as menos vagas, a fim de permitir maiores convergências entre futuras anotações. Tais categorias e suas novas explicações podem ser encontradas no subcapítulo seguinte: Categorias SL2.

\subsection{2}

\section{Categorias SL2}

\begin{tabular}{|c|c|c|}
\hline CATEGORIAS & \multicolumn{2}{|c|}{ EXPLICAÇÕES } \\
\hline & \multicolumn{2}{|c|}{$\begin{array}{l}\text { É a estratégia que consiste em traduzir um substantivo, adjetivo, } \\
\text { uma oração/um período ou verso do original alterando seus } \\
\text { elementos semânticos em um substantivo, adjetivo, uma oração/um } \\
\text { período ou verso correspondente da tradução. As alterações } \\
\text { semânticas que ocorrem entre conjunções, artigos, preposições e } \\
\text { pronomes isolados, da tradução e do original, não serão levadas em } \\
\text { consideração. } \\
\text { Podemos considerar que há alteração de elementos semânticos do } \\
\text { original nos seguintes casos, em que a tradução não utiliza } \\
\text { sinônimos, hipônimos ou hiperônimos: }\end{array}$} \\
\hline \multicolumn{3}{|l|}{ ALTERAÇÃO } \\
\hline SEMÂNTICA & $\begin{array}{l}\text { Pourest thy }\{\text { full }\}^{\text {asem }} \text { heart } \\
\text { In profuse strains of } \\
\text { [unpremeditated art }\end{array}$ & $\begin{array}{l}\text { Teu coração }\{\text { suave }\}^{\text {asem }} \\
\text { Derramas sem pensar, em } \\
\quad[\text { arte sem entrave }\end{array}$ \\
\hline & \multicolumn{2}{|c|}{ Nesse caso, temos "suave" como a tradução de "full" (pleno, } \\
\hline
\end{tabular}




\begin{tabular}{|c|c|}
\hline & $\begin{array}{l}\text { repleto). "Suave" não é sinônimo, hipônimo ou hiperônimo de } \\
\text { "pleno, repleto", dessa forma, podemos dizer que há alteração } \\
\text { semântica na tradução de "full" por "suave". }\end{array}$ \\
\hline & \begin{tabular}{|l|l|}
$\{\text { Melts }\}^{\text {asem }}$ around thy flight & Em torno a ti $\{\text { esfria }\}^{\text {asem }}$
\end{tabular} \\
\hline & $\begin{array}{l}\text { Nesse caso, temos "esfria" como a tradução de "melts" } \\
\text { (derrete). "Esfria" não é sinônimo, hipônimo ou hiperônimo de } \\
\text { "derrete", de/ssa forma, podemos dizer que há alteração semântica } \\
\text { na tradução de "melts" por "esfria". }\end{array}$ \\
\hline & \begin{tabular}{|l|l|} 
Of thy $\{\text { happy }\}^{\text {asem }}$ strain? & Do teu canto $\{\text { em flor }\}^{\text {asem }} ?$ \\
\end{tabular} \\
\hline & $\begin{array}{l}\text { Nesse caso, temos "em flor" como a tradução de "happy" } \\
\text { (feliz, alegre, contente). "Em flor" não é sinônimo, hipônimo ou } \\
\text { hiperônimo de "feliz, alegre, contente", dessa forma, podemos dizer } \\
\text { que há alteração semântica na tradução de "happy" por "em flor". }\end{array}$ \\
\hline OMISSÃO & $\begin{array}{l}\text { É a estratégia de tradução que consiste na omissão de elementos } \\
\text { semânticos presentes em um substantivo, adjetivo, uma oração/um } \\
\text { período ou verso da estrofe do original. As omissões de conjunções, } \\
\text { artigos, preposições e pronomes isolados não serão levadas em } \\
\text { consideração. }\end{array}$ \\
\hline ACRÉSCIMO & $\begin{array}{l}\text { É a estratégia de tradução que consiste no acréscimo de elementos } \\
\text { semânticos que não estão presentes na estrofe do original, através de } \\
\text { um substantivo, adjetivo, uma oração/ um período ou verso da } \\
\text { tradução. Os acréscimos de conjunções, artigos, preposições e } \\
\text { pronomes isolados não serão levados em consideração. }\end{array}$ \\
\hline
\end{tabular}

Foram utilizadas por mim e por EF para anotarmos o estudo de caso 1, quanto ao nível semântico-lexical. Os resultados obtidos ao compararmos a minha anotação com a de EF levaram-me a refinar todas as três categorias, começando por OMISSÃO, que foi a categoria que levou a mais discordâncias. Com os resultados, percebi a necessidade de incluir advérbios em suas explicações. Ao considerar incluir advérbios em OMISSÃO, 
dei-me conta de que verbos, assim como advérbios, possuem importante carga semântica, e que alterações, acréscimos ou omissões que envolvessem advérbios e/ou verbos seriam fatores relevantes a serem levados em conta em anotações e futuras avaliações de traduções de poemas. Dessa forma, julguei necessário modificar as explicações de OMISSÃO, ALTERAÇÃO SEMÂNTICA e ACRÉSCIMO, para que incluíssem, respectivamente, omissão de elementos semânticos presentes em advérbios e verbos; alteração de elementos semânticos presentes em advérbios e verbos; e acréscimo de elementos semânticos presentes em advérbios e verbos. Tais categorias e suas novas explicações podem ser no subcapítulo seguinte: Categorias SL3.

\subsection{3}

\section{Categorias SL3}

\begin{tabular}{|c|c|c|}
\hline CATEGORIAS & \multicolumn{2}{|c|}{ EXPLICAÇÕES } \\
\hline \multirow{4}{*}{$\begin{array}{l}\text { ALTERAÇÃO } \\
\text { SEMÂNTICA }\end{array}$} & \multicolumn{2}{|c|}{$\begin{array}{l}\text { É a estratégia que consiste em traduzir um substantivo, adjetivo, } \\
\text { advérbio, verbo, uma oração/um período ou verso do original } \\
\text { alterando seus elementos semânticos em um substantivo, adjetivo, } \\
\text { advérbio, verbo, uma oração/um período ou verso correspondente da } \\
\text { tradução. As alterações semânticas que ocorrem entre conjunções, } \\
\text { artigos, preposições e pronomes isolados, da tradução e do original, } \\
\text { não serão levadas em consideração. } \\
\text { Podemos considerar que há alteração de elementos semânticos do } \\
\text { original nos seguintes casos, em que a tradução não utiliza } \\
\text { sinônimos, hipônimos ou hiperônimos: }\end{array}$} \\
\hline & & \\
\hline & $\begin{array}{l}\text { Pourest thy }\{\text { full }\}^{\text {asem }} \text { heart } \\
\text { In profuse strains of } \\
\text { [unpremeditated art }\end{array}$ & $\begin{array}{l}\text { Teu coração }\{\text { suave }\}^{\text {asem }} \\
\text { Derramas sem pensar, em } \\
\quad[\text { arte sem entrave }\end{array}$ \\
\hline & \multicolumn{2}{|c|}{$\begin{array}{l}\text { Nesse caso, temos "suave" como a tradução de "full" (pleno, } \\
\text { repleto). "Suave" não é sinônimo, hipônimo ou hiperônimo de } \\
\text { "pleno, repleto", dessa forma, podemos dizer que há alteração }\end{array}$} \\
\hline
\end{tabular}




\begin{tabular}{|c|c|}
\hline & semântica na tradução de "full" por "suave". \\
\hline & $\{\text { Melts }\}^{\text {asem }}$ around thy flight \\
\hline & $\begin{array}{l}\text { Nesse caso, temos "esfria" como a tradução de } \\
\text { "melts"(derrete). "Esfria" não é sinônimo, hipônimo ou hiperônimo } \\
\text { de "derrete", de/ssa forma, podemos dizer que há alteração } \\
\text { semântica na tradução de "melts" por "esfria". }\end{array}$ \\
\hline & Of thy $\{\text { happy }\}^{\text {asem }}$ strain? \\
\hline & $\begin{array}{l}\text { Nesse caso, temos "em flor" como a tradução de "happy" } \\
\text { (feliz, alegre, contente). "Em flor" não é sinônimo, hipônimo ou } \\
\text { hiperônimo de "feliz, alegre, contente", dessa forma, podemos dizer } \\
\text { que há alteração semântica na tradução de "happy" por "em flor". }\end{array}$ \\
\hline OMISSÃO & $\begin{array}{l}\text { É a estratégia de tradução que consiste na omissão de elementos } \\
\text { semânticos presentes em um substantivo, adjetivo, advérbio, verbo, } \\
\text { uma oração/um período ou verso da estrofe do original. As omissões } \\
\text { de conjunções, artigos, preposições e pronomes isolados não serão } \\
\text { levadas em consideração. }\end{array}$ \\
\hline ACRÉSCIMO & $\begin{array}{l}\text { É a estratégia de tradução que consiste no acréscimo de elementos } \\
\text { semânticos que não estão presentes na estrofe do original, através de } \\
\text { um substantivo, adjetivo, advérbio, verbo, uma oração/um período } \\
\text { ou verso da tradução. Os acréscimos de conjunções, artigos, } \\
\text { preposições e pronomes isolados não serão levados em } \\
\text { consideração. }\end{array}$ \\
\hline
\end{tabular}

Foram utilizadas por mim, por AS e por MM para anotarmos o estudo de caso 1, quanto ao nível semântico-lexical. Os resultados obtidos ao compararmos a minha anotação com as de AS e MM levaram-me a refinar todas as três categorias, começando por OMISSÃO. Percebi a necessidade de incluir a questão da elipse, pronomes pessoais e das interjeições em suas explicações. Ao considerar fazer tais inclusões em OMISSÃO, dei-me conta de que seria importante levar em conta a questão dos 
pronomes pessoais e das interjeições também em relação a alterações semânticas e acréscimos, a fim de evitar dúvidas e divergências em futuras anotações e avaliações de traduções de poemas. Assim, julguei necessário modificar as explicações de OMISSÃO, ALTERAÇÃO SEMÂNTICA e ACRÉSCIMO, incluindo, respectivamente, os seguintes períodos: não consideraremos como OMISSÕES traduções que utilizem elipses que subentendem elementos semânticos presentes em um substantivo, adjetivo, advérbio, verbo, uma oração/um período ou verso da estrofe do original, ou que utilizem elipses de pronomes ou pronomes que se refiram a personagens presentes na estrofe do original + as omissões de conjunções, artigos, preposições, interjeições e pronomes isolados não serão levadas em consideração; não consideraremos como ALTERAÇÃO SEMÂNTICA traduções que utilizem pronomes que se refiram a personagens presentes no termo ou trecho correspondente do original +as alterações semânticas que ocorrem entre conjunções, artigos, preposições, interjeições e pronomes isolados, da tradução e do original, não serão levadas em consideração; e não consideraremos como ACRÉSCIMO traduções que utilizem pronomes que se refiram a personagens presentes na estrofe do original + os acréscimos de conjunções, artigos, preposições, interjeições e pronomes isolados não serão levados em consideração. Tais categorias e suas novas explicações podem ser encontradas no próximo subcapítulo: Categorias SL4.

\subsection{4}

Categorias SL4

\begin{tabular}{|l|l|}
\hline CATEGORIAS & \multicolumn{1}{|c|}{ EXPLICAÇÕES } \\
\hline & $\begin{array}{l}\text { É a estratégia que consiste em traduzir um substantivo, adjetivo, } \\
\text { advérbio, verbo, uma oração/um período ou verso do original } \\
\text { alterando seus elementos semânticos em um substantivo, adjetivo, } \\
\text { advérbio, verbo, uma oração/um período ou verso correspondente da } \\
\text { tradução. } \\
\text { Podemos considerar que há alteração de elementos semânticos do }\end{array}$ \\
\hline
\end{tabular}




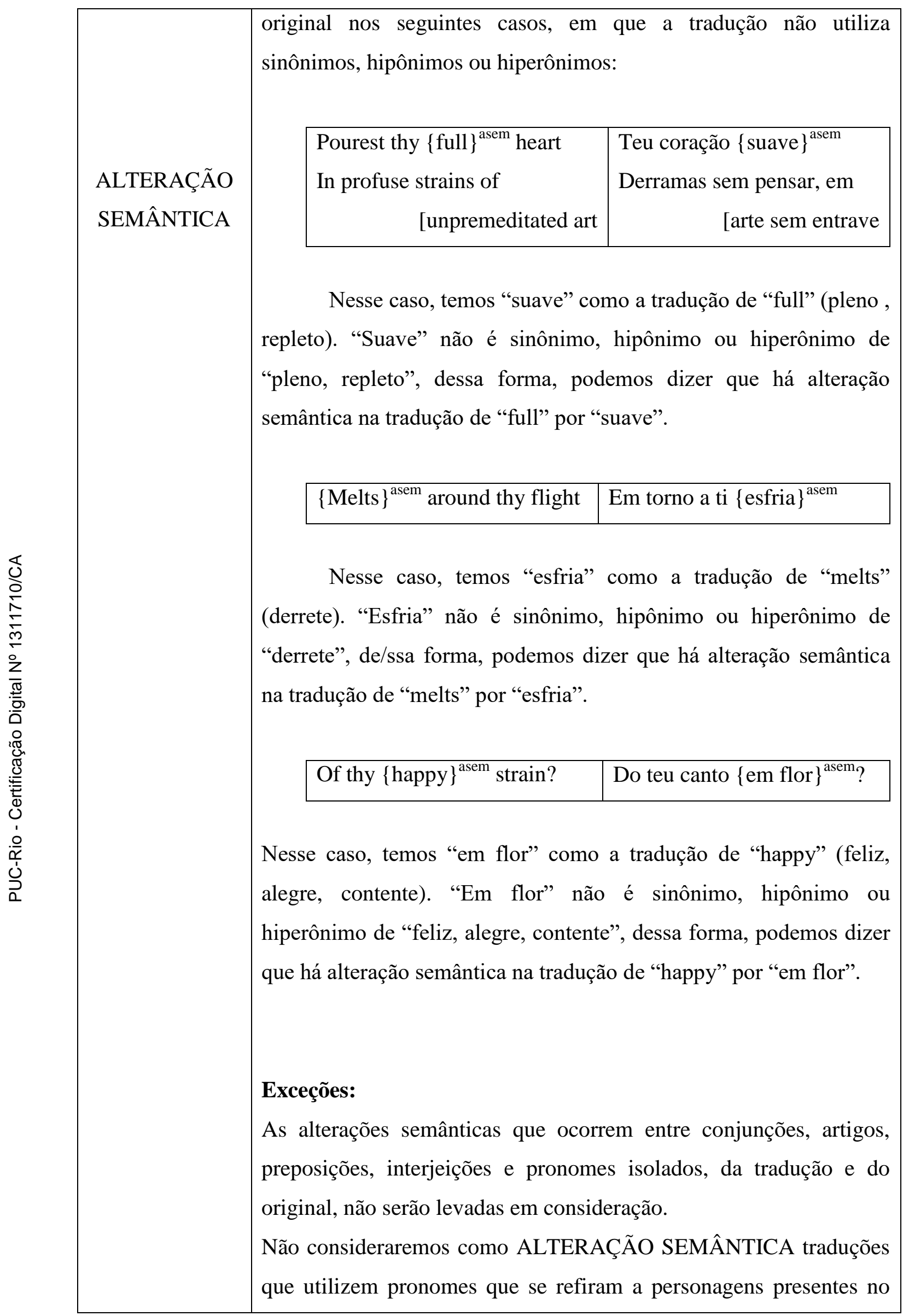




\begin{tabular}{|c|c|}
\hline & termo ou trecho correspondente do original. \\
\hline OMISSÃO & $\begin{array}{l}\text { É a estratégia de tradução que consiste na omissão de elementos } \\
\text { semânticos presentes em um substantivo, adjetivo, advérbio, verbo, } \\
\text { uma oração/um período ou verso da estrofe do original. } \\
\text { Exceções: } \\
\text { As omissões de conjunções, artigos, preposições, interjeições e } \\
\text { pronomes isolados não serão levadas em consideração. } \\
\text { Não consideraremos como OMISSÕES traduções que utilizem } \\
\text { elipses que subentendem elementos semânticos presentes emum } \\
\text { substantivo, adjetivo, advérbio, verbo, uma oração/um período ou } \\
\text { verso da estrofe do original, ou que utilizem elipses de pronomes ou } \\
\text { pronomes que se refiram a personagens presentes na estrofe do } \\
\text { original. }\end{array}$ \\
\hline ACRÉSCIMO & $\begin{array}{l}\text { É a estratégia de tradução que consiste no acréscimo de elementos } \\
\text { semânticos que não estão presentes na estrofe do original, através de } \\
\text { um substantivo, adjetivo, advérbio, verbo, uma oração/um período } \\
\text { ou verso da tradução. } \\
\text { Exceções: } \\
\text { Os acréscimos de conjunções, artigos, preposições, interjeições e } \\
\text { pronomes isolados não serão levados em consideração. } \\
\text { Não consideraremos como ACRÉSCIMO traduções que utilizem } \\
\text { pronomes que se refiram a personagens presentes na estrofe do } \\
\text { original. }\end{array}$ \\
\hline
\end{tabular}

\section{2}

Nível formal: categorias $F$

\begin{tabular}{|c|c|}
\hline CATEGORIAS & EXPLICAÇÕES \\
\hline & \\
RIMAS & \\
\hline
\end{tabular}




\begin{tabular}{|c|c|}
\hline $\begin{array}{l}\text { (poemas em inglês e } \\
\text { português) }\end{array}$ & Rima é a repetição de sons ao fim de dois ou mais versos. \\
\hline $\begin{array}{l}\text { SÍMBOLOS PARA } \\
\text { ESCANSÃO } \\
\text { (poemas em inglês e } \\
\text { português) }\end{array}$ & $\begin{array}{l}\text { Escansão é a ação ou resultado de escandir, de decompor um } \\
\text { verso em seus componentes métricos. Para isso, é possível } \\
\text { utilizar diferentes símbolos, que podem corresponder, por } \\
\text { exemplo, a acentos primários; acentos secundários, } \\
\text { separadores de pés (somente em poemas em inglês); pausas; } \\
\text { e sílabas átonas. }\end{array}$ \\
\hline \multirow{6}{*}{ (poemas em inglês) } & O pé é a unidade rítmica mínima do verso em inglês. \\
\hline & Os mais comuns são: \\
\hline & $\begin{array}{l}\text { a.1. Jambo: - / (sílaba átona + sílaba acentuada); } \\
\text { a.2. Troqueu: / - (sílaba acentuada+ sílabas átona); } \\
\text { a.3. Anapesto: - - / (sílaba átona + sílaba átona + sílaba } \\
\text { acentuada); } \\
\text { a.4. Espondeu: / / (sílaba acentuada+ sílabas } \\
\text { acentuada); e } \\
\text { a.5. Pirríquio: - - (sílaba átona + sílaba átona) }\end{array}$ \\
\hline & $\begin{array}{l}\text { Jambo, troqueu, espondeu e pirríquio são pés binários } \\
\text { (duas sílabas); e o anapesto é um pé ternário (três } \\
\text { sílabas). }\end{array}$ \\
\hline & Escansão de um verso em inglês: \\
\hline & $\begin{array}{c}/ \\
\text { Jeers, that his laughter, like a jangled chime, }\end{array}$ \\
\hline
\end{tabular}




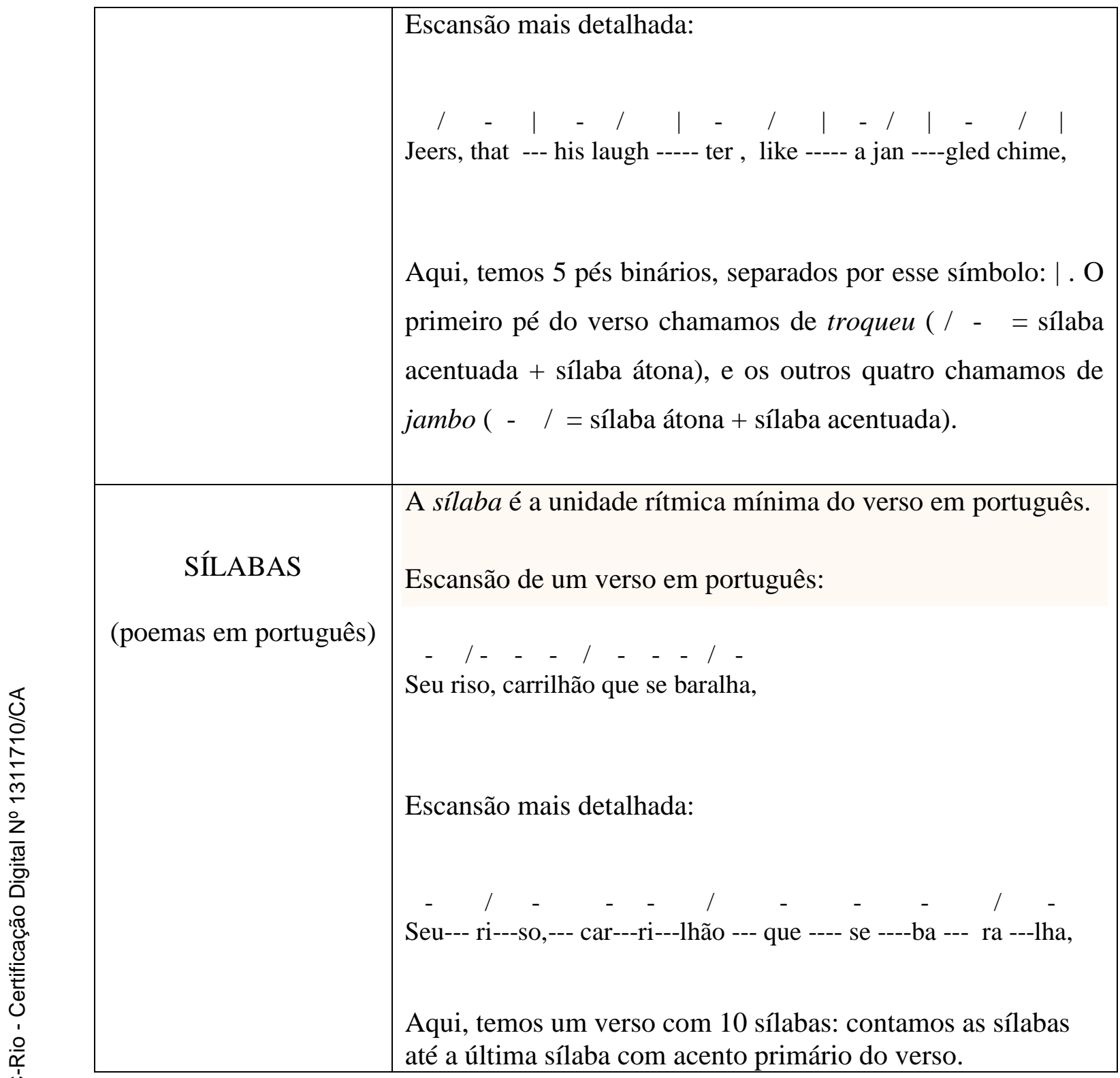

\section{3}

Plano de recursos sonoros: categorias RS

\begin{tabular}{|l|l|l|}
\hline CATEGORIAS & \multicolumn{5}{|c|}{ EXPLICAÇÕES } \\
\hline & As aliterações consistem na repetição de consoantes, \\
& principalmente no início de palavras ou em sílabas acentuadas de \\
ALITERAÇÕES & palavras presentes em um mesmo verso ou em versos \\
\hline
\end{tabular}




\begin{tabular}{|c|c|}
\hline & $\begin{array}{l}\text { consecutivos. Em inglês, as aliterações também podem ocorrer } \\
\text { entre semivogais, nas condições já descritas aqui. }\end{array}$ \\
\hline ASSONÂNCIAS & $\begin{array}{l}\text { As assonâncias consistem na repetição de vogais, principalmente } \\
\text { no início de palavras e em sílabas acentuadas de palavras presentes } \\
\text { em um mesmo verso ou em versos consecutivos. }\end{array}$ \\
\hline $\begin{array}{l}\text { RIMAS } \\
\text { INTERNAS }\end{array}$ & $\begin{array}{l}\text { As rimas internas consistem na repetição da parte final da palavra, } \\
\text { a partir da última vogal tônica, em palavras diferentes em uma } \\
\text { mesma estrofe. Não consideramos como rima interna as rimas que } \\
\text { ocorrem somente entre palavras em fim de verso. Em inglês, há } \\
\text { ainda a possibilidade da rima interna átona, em que a última sílaba } \\
\text { da palavra, quando átona, repete-se, nas condições já descritas } \\
\text { aqui. }\end{array}$ \\
\hline $\begin{array}{l}\text { REPETIÇÕES } \\
\text { DIVERSAS }\end{array}$ & $\begin{array}{l}\text { As repetições diversas consistem na repetição de palavras ou } \\
\text { trechos no início, no final ou em qualquer outro lugar dos versos, } \\
\text { consecutivos ou não, em uma mesma estrofe. Elas também } \\
\text { consistem em repetições de palavras ou trechos em estrofes } \\
\text { consecutivas, ou intercaladas. As repetições diversas também } \\
\text { consistem na repetição de um radical em palavras diferentes em } \\
\text { uma mesma estrofe. }\end{array}$ \\
\hline
\end{tabular}

\section{4}

\section{Guias}

Todos os anotadores, incluindo eu, usaram guias para auxiliá-los nas anotações. Tais guias apresentam categorias $S L$ (nível semântico-lexical) ou categorias $F$ e $R S$ (nível formal e plano de recursos sonoros, respectivamente), seguidas de exemplos, extraídos de obras literárias e trabalhos acadêmicos. Ao final de cada guia, há um exemplo de estudo de casojá anotado por mim, para servir de modelo para outros anotadores. O exemplo de estudo decaso presente em cada um dos guias é o original "The last metamorphosis of Mephistopheles", de Frank Marzials, e a tradução de Fernando Pessoa. Os anotadores, incluindo eu, nas anotações dos estudos de caso, 
levarão sempre em conta as categorias, os exemplos que se seguem, e o exemplo de estudo de caso.

Os guias SL1, SL2, SL3 e SL4, que apresentam as categorias SL1, SL2, SL3 e SL4, respectivamente; o guia F, que apresenta as categorias F; e o guia RS, que apresenta as categorias RS, podem ser encontrados no capítulo Anexos, subcapítulo Anexos B: guias. 


\section{Metodologia e procedimentos da pesquisa: três etapas}

Na primeira etapa, a anotação é utilizada como metodologia na busca pelo consenso. Na segunda, a metodologia de Britto (2002; 2006c), com algumas observações adicionais, é utilizada para analisar os resultados oriundos da primeira etapa. E na terceira, os resultados da segunda etapa são utilizados a fim de se gerar recursos para uma possível avaliação entre duas traduções do soneto 130 de Shakespeare. Antes de partirmos para os procedimentos de cada etapa, nos três subcapítulos seguintes trato da escolha pela anotação manual através de recursos do Word, pelos determinados estudos de caso e também anotadores.

\section{1}

\section{Ferramentas de anotação: recursos do Word}

A anotação pode ser feita por máquina, ou então, de forma manual. Quando é feita manualmente, é realizada com auxílio de ferramentas específicas para este fím, como a ferramenta Gate ${ }^{13}$, dentre outras. Neste estudo, a anotação foi conduzida sem o auxílio de uma ferramenta específica, porque, para atingir os objetivos deste estudo, os recursos do Word são suficientes, não havendo necessidade de eu e os demais anotadores aprendermos a utilizar uma ferramenta específica. Exponho abaixo as instruções para anotação com recursos do Word:

\section{As categorias SL}

\begin{tabular}{|l|l|}
\hline CATEGORIAS & \multicolumn{1}{|c|}{ INSTRUÇÕES E RECURSOS } \\
\hline & $\begin{array}{l}\text { Devem ser anotadas da seguinte forma: }\{\mathrm{XXXXX}\}^{\text {dup }} \\
\text { DUPLICAÇÃO }\end{array}$ \\
\hline
\end{tabular}

\footnotetext{
${ }^{13}$ Informações sobre essa ferramenta estão disponíveis em: https://gate.ac.uk/family/coming-soon/teamware-1.2.2-guide.pdf
} 


\begin{tabular}{|c|c|}
\hline & chaves. \\
\hline ENXUGAMENTO & $\begin{array}{l}\text { Devem ser anotados da seguinte forma: }\{\text { XXXXX }\}^{\text {enx }} \text {, } \\
\text { mantendo sempre o termo ou o trecho a ser anotado entre duas } \\
\text { chaves. }\end{array}$ \\
\hline EXPLICITAÇÃO & $\begin{array}{l}\text { Devem ser anotadas da seguinte forma: }\{\text { XXXXX }\}^{\text {exp }} \text {, } \\
\text { mantendo sempre o termo ou o trecho a ser anotado entre duas } \\
\text { chaves. }\end{array}$ \\
\hline DESLOCAMENTO & $\begin{array}{l}\text { Devem ser anotados da seguinte forma: }\{\text { XXXXX }\}^{\text {des }} \text {, } \\
\text { mantendo sempre o termo ou o trecho a ser anotado entre duas } \\
\text { chaves. }\end{array}$ \\
\hline INVERSÃO & $\begin{array}{l}\text { Devem ser anotadas da seguinte forma: } \\
\{\mathrm{XXXXX}\}^{\text {inv }} \text {, mantendo sempre o termo ou o trecho a ser } \\
\text { anotado entre duas chaves. }\end{array}$ \\
\hline $\begin{array}{l}\text { ALTERAÇÃO } \\
\text { SEMÂNTICA }\end{array}$ & $\begin{array}{l}\text { Devem ser anotadas da seguinte forma: }\{\text { XXXXX }\}^{\text {asem }} \text {, } \\
\text { mantendo sempre o termo ou o trecho a ser anotado entre duas } \\
\text { chaves. }\end{array}$ \\
\hline OMISSÃO & $\begin{array}{l}\text { Devem ser anotadas da seguinte forma: } \\
\{\mathrm{XXXXX}\}^{\text {omi }} \text {, mantendo sempre o termo ou o trecho a ser } \\
\text { anotado entre duas chaves. }\end{array}$ \\
\hline ACRÉSCIMO & $\begin{array}{l}\text { Devem ser anotados da seguinte forma: }\{\text { XXXXX }\}^{\text {acr }} \text {, } \\
\text { mantendo sempre o termo ou o trecho a ser anotado entre duas } \\
\text { chaves. }\end{array}$ \\
\hline
\end{tabular}

\section{As categorias $\mathbf{F}$}




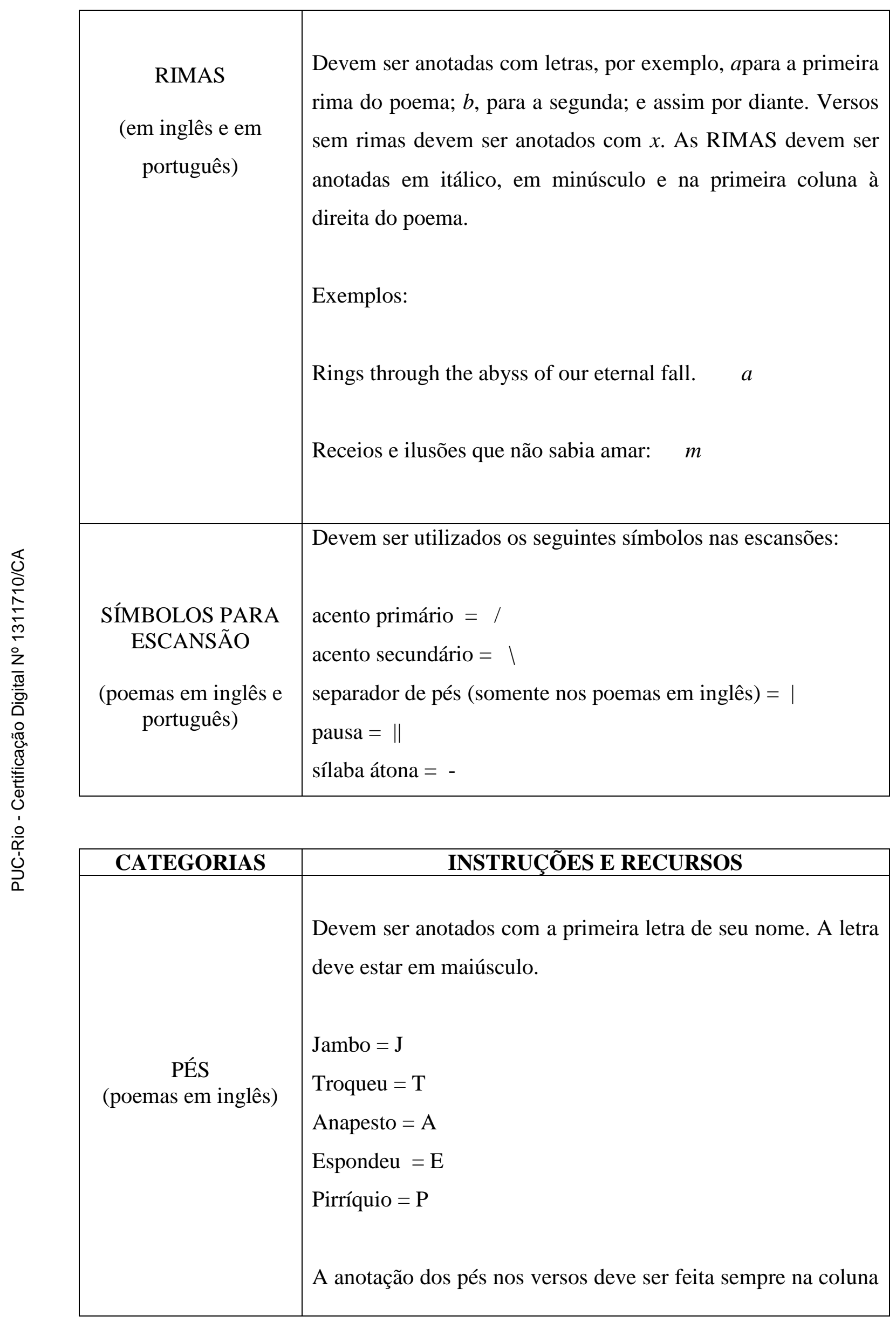




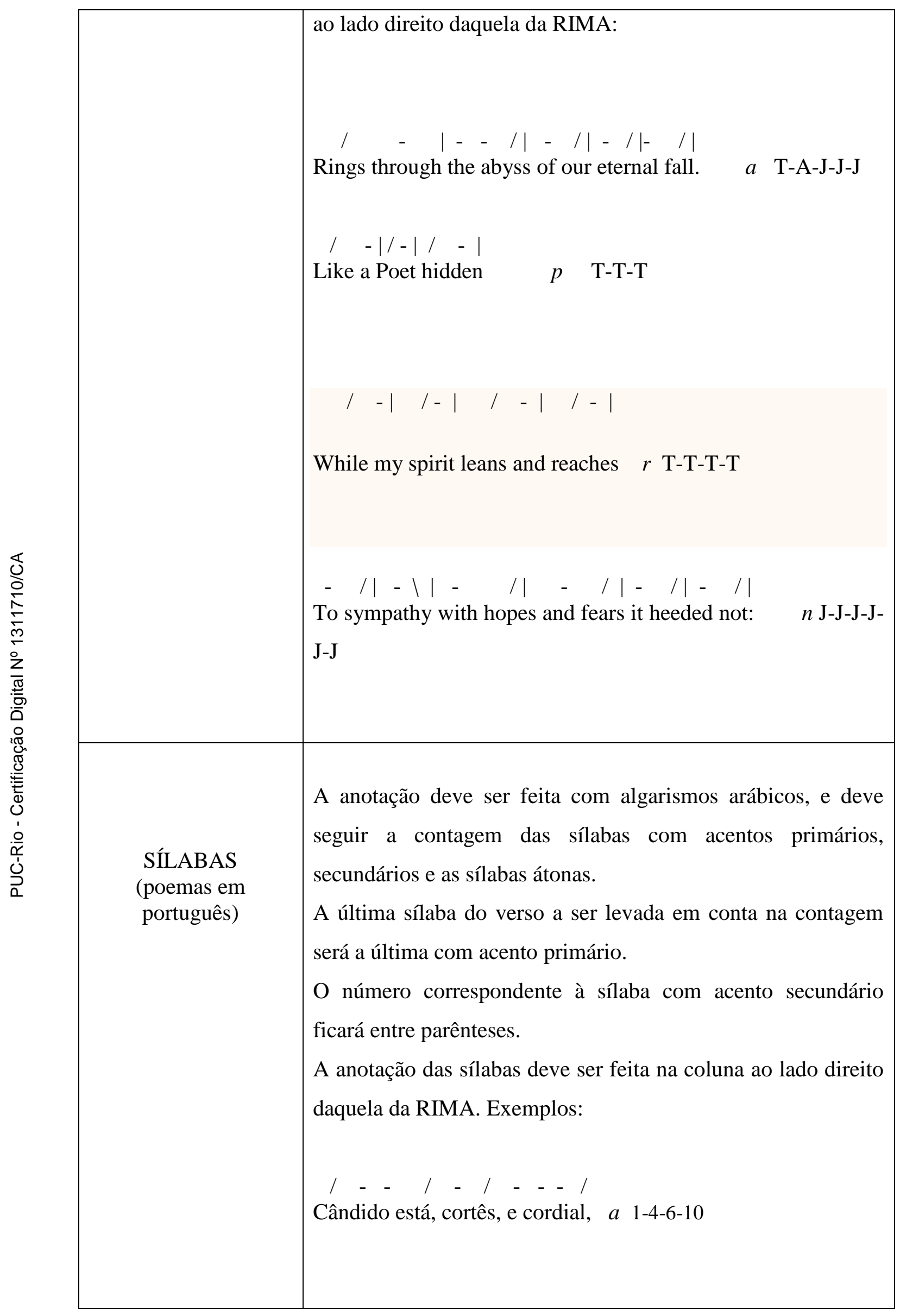




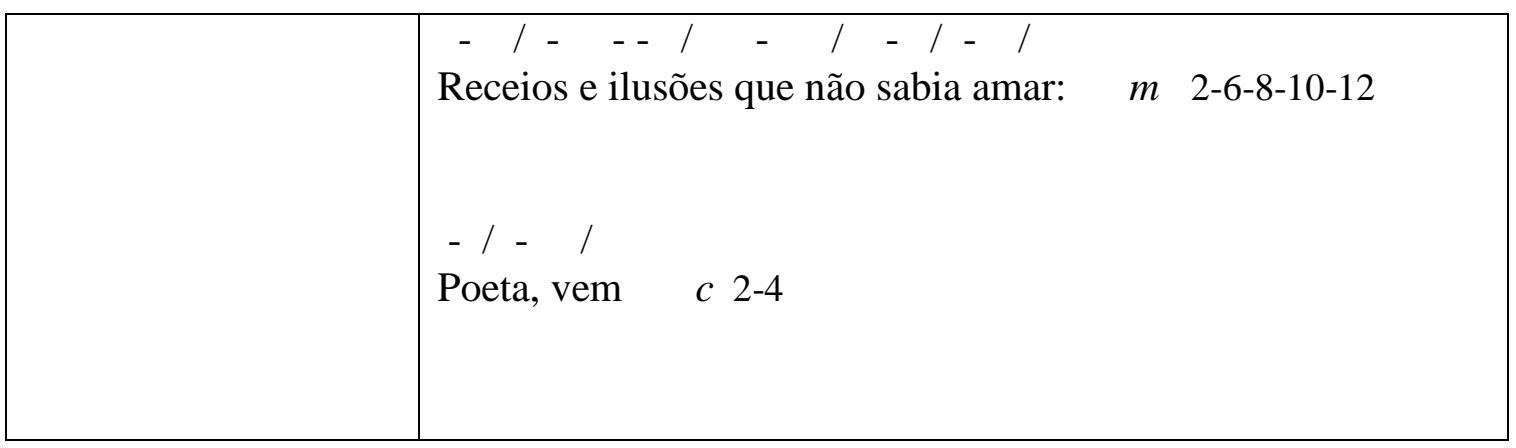

\section{As categorias RS}

\begin{tabular}{|c|c|}
\hline CATEGORIAS & INSTRUÇÕES E RECURSOS \\
\hline ALITERAÇÕES & $\begin{array}{l}\text { Devem ser anotadas da seguinte forma: }\{X\}^{\text {ali }} \text {, mantendo sempre a } \\
\text { representação gráfica da aliteração entre duas chaves. }\end{array}$ \\
\hline ASSONÂNCIAS & $\begin{array}{l}\text { Devem ser anotadas da seguinte forma: } \\
\{X\}^{\text {asson }} \text {, mantendo sempre a representação gráfica da assonância } \\
\text { entre duas chaves. }\end{array}$ \\
\hline $\begin{array}{l}\text { RIMAS } \\
\text { INTERNAS }\end{array}$ & $\begin{array}{l}\text { Devem ser anotadas da seguinte forma: } \\
\{X\}^{\text {ri }} \text {, mantendo sempre a representação gráfica da rima interna } \\
\text { entre duas chaves. }\end{array}$ \\
\hline $\begin{array}{l}\text { REPETIÇÕES } \\
\text { DIVERSAS }\end{array}$ & $\begin{array}{l}\text { Devem ser anotadas da seguinte forma: }\{X\}^{\text {repd }} \text {, mantendo sempre } \\
\text { o termo ou o trecho que se repete entre duas chaves. }\end{array}$ \\
\hline
\end{tabular}

\section{2}

\section{Estudos de caso}

Os estudos de caso possuem algumas características em comum, tais como: 
(a) Original em inglês, e tradução em português;

(a) Poemas formais: não trabalharei com traduções e poemas originais escritos em verso livre.

Esses aspectos em comum estão de acordo com as seguintes razões pelas quais escolhi os estudos de caso, respectivamente,

(a) Tenho um excelente domínio somente dos idiomas inglês e português;

(b) Há ainda estudos em andamento quanto aos diversos tipos de verso livre, tais como aquele apresentado no artigo de Britto (2011): "Para uma tipologia do verso livre em português e inglês". Como há ainda um longo caminho a percorrer nos estudos desses tipos de verso, optei por trabalhar somente com o verso formal, que já apresenta uma bibliografia sólida, em ambos os idiomas que utilizo neste trabalho.

O estudo de caso lé composto pelo soneto 130, de William Shakespeare, e pela tradução de Ivo Barroso; e o estudo de caso 2é composto por esse mesmo soneto, e pela tradução de Jorge Wanderley.

\subsection{1}

\section{Soneto 130}

Tal poema é um dos sonetos de Shakespeare dedicados à Dark Lady ("Dama Negra"), uma mulher com quem Shakespeare se relacionou. Segundo Wanderley, ela

era morena, possivelmente bem tisnada, uma característica inferiorizante, numa sociedade elizabetana, onde a beleza era sinônimo(fair) de cabelos louros, pele clara olhos azuis ou verdes. [...] tocava um instrumento musical (possivelmente uma espineta $^{14}$ ), e que teria o que hoje chamaríamos de um "temperamento musical"; que em sua vida passavam, "como em sorvedouro", muitos homens e que estas relações, como era frequente na sociedade elizabetana, estavam longe de ser inocentes ou castas [...] (WANDERLEY, 1991, p.13)

De acordo com Wanderley, Shakespeare disputava a atenção da Dama Negra com Southampton, um nobre por quem o poeta também nutria sentimentos. O soneto 133 trata desse triângulo amoroso.

O soneto 130 trata somente da Dama Negra. Ao longo das três quadras, o eulírico não a idealiza, satirizando suas características. No dístico final, elea enaltece.

\footnotetext{
${ }^{14}$ De acordo com o Aulete Digital (2006), espineta seria: "Antigo instrumento de teclado e cordas percutíveis, semelhante ao cravo, mas de época anterior". Disponível em: www.aulete.com.br/espineta
} 


\subsection{2}

\section{Ivo Barroso}

Barroso é considerado um dos tradutores de literatura mais importantes no Brasil do século XX. Abaixo apresento algumas informações sobre esse renomado tradutor, retiradas do verbete "Ivo Barroso", do Dicionário de tradutores literários no Brasil, da UFSC:

foi aluno da antiga Faculdade Nacional de Filosofia do Rio de Janeiro, onde fez o curso de línguas e literaturas neolatinas. Desde cedo se dedicou à tradução de poesia, incentivado por seus mestres. Já na década de 60 , integrou o movimento concretista que tinha no Suplemento Literário do Jornal do Brasil, seu veículo de expressão, no qual publicou várias de suas traduções e poemas originais. Pertenceu ao grupo redatorial da revista Senhor, e foi escolhido por Paulo Rónai para integrar o grupo de tradutores encarregado dos trabalhos da Coleção dos Prêmios Nobel de Literatura. Em 1968, seguiu para a Holanda, onde começou a traduzir os Sonetos de Shakespeare. [...]Consagrou grande parte da sua vida à tradução dos poemas de Rimbaud. Em 1995, lançou, pela Topbooks, o primeiro volume das obras completas do autor francês, seguido em 1998 de Prosa Poética, com o qual ganhou o prêmio Jabuti de tradução. Ganhou também o Prêmio Jabuti pela tradução de O livro dos gatos, de T. S. Eliot, em 1992; o Prêmio Paulo Rónai da Biblioteca Nacional pela Novela do bom Velho e da Bela Mocinha, de Italo Svevo, em 1997 e em 2005, ganhou o prêmio da ABL (Academia Brasileira de Letras) de tradução por seu trabalho no Teatro completo, de T. S. Eliot. (VERÇOSA;GUERINI, 2005)

Foi lançado, também em 2005, uma obra bilíngue — 42 sonetos, de Shakespeare - traduzidos para o português por Barroso. Dentre os originais e traduções, podemos encontrar o soneto 130 e a tradução deste escritor, que compõem o estudo de caso 1 da presente tese.

\subsection{3 \\ Jorge Wanderley}

Wanderley é considerado um dos tradutores de literatura mais renomados no Brasil do século XX. Abaixo apresento algumas informações sobre esse tradutor tão importante, retiradas do verbete "Jorge Wanderley", da ENCICLOPÉDIA Itaú Cultural de Arte e Cultura Brasileiras:

Foi médico, professor de literatura brasileira e teoria da literatura, poeta e tradutor. Sua obra poética é composta de quatro livros lançados entre 1960 e 1999 e postumamente reunidos no volume Antologia poética (Ateliê, 2002). Publicou também um livro de ensaios (Edusp, 1994). Organizou antologias de poetas de língua inglesa: Antologia da nova poesia norte-americana (Civilização Brasileira, 1992), e 22 ingleses modernos: uma antologia poética (Civilização Brasileira, 1993). Suas traduções de poetas 
mulheres foram reagrupadas posteriormente no volume Do jeito delas, vozes femininas de língua inglesa (7Letras, 2008), com poemas de Sylvia Plath, Emily Dickinson, Marianne Moore, Anne Sexton, Hilda Doolittle, Louise Bogan, Elizabeth Bishop, Denise Levertov, Edna St. Vincent Millay, Edith Sitwell, Patricia Hooper e Elinor Wylie. Além das antologias, Wanderley publicou outros sete volumes com traduções de poesia, incluindo Vida Nova (Taurus/Timbre, 1987), Lírica (Topbooks, 1996) e Inferno (Record, 2004), de Dante Alighieri, que lhe rendeu o prêmio Jabuti de tradução naquele ano. Traduziu ainda Sonetos (Civilização Brasileira, 1991) de Shakespeare, Os 25 melhores poemas de Charles Bukowski (Bertrand Brasil, 2003), Poemas (Topbooks, 1995), de Lawrence Durrel, e Cemitério marinho, de Paul Valéry (Fontana, 1974). Traduziu também dois poemas de Richard Wilbur para a antologia Nova poesia norteamericana: Quingumbo, organizada por Kerry Shawn Keys. (ENCICLOPÉDIA Itaú Cultural de Arte e Cultura Brasileiras, 2016)

Foi lançado, em 1991, uma obra bilíngue - Sonetos, de Shakespeare traduzidos para o português por Wanderley. Dentre os originais e traduções, podemos encontrar o soneto 130 e a tradução deste escritor, que compõem o estudo de caso 2 da presente tese.

\section{3}

\section{Anotadores}

Procurei utilizar, como anotadores, tradutores e / ou estudiosos de poesia familiarizados com poemas e suas traduções. Creio que anotadores com essas características são capazes de anotar os estudos de caso quanto ao nível semânticolexical, nível formal e ao plano de recursos sonoros.

Alguns dos anotadores, tais como $\mathrm{AD}^{15}$, não possuíam um vasto conhecimento em relação à versificações inglesa e portuguesa. Dessa forma, a autora deste trabalho forneceu algumas noções importantes referentes a essas versificações, pessoalmente ou por Skype, para que tais voluntários fossem capazes de anotar os estudos de caso quanto ao nível formal. Abaixo há algumas informações acerca de todos os anotadores, quanto à experiência profissional e acadêmica relevante para a presente pesquisa:

\footnotetext{
${ }^{15}$ Ao longo de todo o trabalho, utilizo siglas para me referir aos anotadores.
} 


\subsection{1}

$\mathrm{JC}^{16}$

Graduada em Letras - Inglês/ Literaturas de Língua Inglesa pela UERJ. Certificada pelo curso de extensão de Formação de Tradutores Inglês-Português da PUC-Rio.Mestre em Letras/ Estudos da Linguagem pela PUC-Rio, e doutora em Letras / Estudos da Linguagem pela mesma universidade.

\subsection{2}

AD

Tradutora inglês-português e revisora de textos, com experiência nas áreas de patentes e medicina. Graduada em Letras - Inglês/Literaturas de Língua Inglesa pela UERJ, certificada pelo curso de extensão de Formação de Tradutores Inglês-Português da PUC-Rio e pós-graduada em Tradução de Inglês pela Universidade Estácio de Sá.

\subsection{3}

EF

EF se graduou em Letras (Tradução Inglês-Português) pela PUC-Rio em 2009, ganhando, no mesmo ano, o Prêmio Destaque de Iniciação Científica da Categoria CNPq do Centro de Teologia e Ciências Humanas da PUC-Rio com o projeto "As traduções brasileiras da poesia de W. B. Yeats", orientado pelo professor Paulo Henriques Britto.

\footnotetext{
${ }^{16}$ JC é Juliana Cunha: autora deste trabalho.
} 


\subsection{4}

AS

AS se graduou em Letras (Português-Inglês, bacharelado em Estudos da Tradução) pela UFPR em 2010 e concluiu o mestrado em Estudos Literários em 2013, sob orientação do prof. Rodrigo Tadeu Gonçalves. Sua dissertação tratou da tradução completa do poema Prometheus Unbound, de Percy Bysshe Shelley, publicada depois em 2015, junto com uma seleção de outros poemas de Shelley, no volume Prometeu Desacorrentado e outros poemas (ed. Autêntica).

\subsection{5}

\section{MM}

MM cursa Direito na Universidade Federal de Goiás e é membro do Kenosis, Grupo de Pesquisa e Extensão em Direito e Arte. É autor do blog Formas fixas, em que reúne textos com ênfase em poesia contemporânea e análise e traduções de poemas.

\section{4}

\section{Primeira etapa}

Cada poema dos estudos de caso foi anotado quanto ao nível semântico-lexical, formal e ao plano de recursos sonoros. As anotações foram feitas por diferentes tradutores, estudiosos de poesia e, também, por mim. Em seguida, fiz a comparação dessas anotações, para que eu pudesse verificar as convergências e divergências entre elas.

\subsection{1}

Procedimentos iniciais: anotações feitas por cada anotador

A anotação dos estudos de casofoi feita utilizando as informações do capítulo Categorias para análise e avaliação de tradução de poesia, e do subcapítulo Ferramentas de anotação: recursos do Word, deste capítulo.Exponho os procedimentos abaixo: 
(a) em nível semântico-lexical:cada anotador, comparando a tradução com o original, anotouas categorias SL nos poemas.

(b)em nível formal:

(b.1) nível métrico: cada anotador anotou os símbolos para escansão do poema original e do traduzido; anotou os pés do original; e anotou as sílabas da tradução.

(b.2) nível rimático: cada anotador anotou as rimas do poema original e do poema traduzido.

(c) no plano de recursos sonoros: cada anotador anotouos recursos sonoros do poema original e do poema traduzido.

\subsection{2}

\section{Procedimentos finais: a comparação das anotações}

A comparação das anotações dos estudos de caso, estas feitas por mim e por outros anotadores, foi feita através detrês verificações:

Primeira verificação:

(a) nível formal: nível métrico e nível rimático:

(a.1) nível métrico:

(a.1.1) no original: verifiquei se houve concordância ou não, entre os anotadores, quanto ao tipo de verso utilizado no poema; e

(a.1.2) na tradução: verifiquei se houve concordância ou não, entre os anotadores, quanto ao número de sílabas em cada verso, e quanto ao tipo de verso utilizado no poema.

(a.2) em relação ao nível rimático, verifiquei se houve concordância ou não, entre os anotadores, quanto à reprodução do esquema rimático do original: se a tradução reproduz o esquema rimático do original; a tradução não reproduz o esquema rimático do original, porém, apresenta um padrão regular de rimas; a tradução não reproduz o esquema rimático do original, e também não apresenta um padrão regular de rimas.

Segunda verificação: 
(b)em nível semântico-lexical,verifiquei:

(b.1) o número de ocorrências de categorias anotadas no total por cada anotador;

(b.2) o total de concordâncias;

(b.3) o total de discordâncias;

(b.4) as categorias que levaram a mais concordâncias;

(b.5) as categorias que levaram a mais discordâncias;

(b.6) as categorias que não foram encontradas.

Terceira verificação:

( c ) quanto ao plano de recursos sonoros, verifiquei:

(c.1) se houve, ao menos, uma ocorrência de recurso no original e uma ocorrência de recurso na tradução que levaram a divergências;

(c.2) se os recursos do original têm função estruturante ou não ${ }^{17}$, e se os recursos da tradução seguem a mesma linha daqueles do original.

Obs1: Quanto ao nível formal e ao plano de recursos sonoros, ao comparar tais anotações, não verifico cada divergência entre as anotações de rimas, pés, sílabas e símbolos para escansão; e nem entre as anotações de aliterações, assonâncias, rimas internas e repetições diversas, respectivamente. Não o faço porque não tenho como objetivo validar as categorias desse nível e plano, como já foi explicado no capítulo Categorias para análise e avaliação de tradução de poesia. Já em relação ao nível semântico-lexical, como tenho como meta validar suas categorias, verifico cada detalhe, como explicitado na verificação (b), presente neste subcapítulo.

Obs2: Nos estudos de caso desta tese, os recursos sonoros não têm função estruturante, nem nos originais e nem nas traduções. Se tivessem tal função no original, eu verificaria se o tradutor tentou reproduzi-los na tradução, também de uma forma padronizada, e faria, além disso, as verificações que podem ser encontradas neste capítulo, em Segunda etapa, no subcapítulo Procedimentos da segunda etapa.

\footnotetext{
${ }^{17}$ Em poemas formais, geralmente apenas as rimas e o metro têm função estruturante; os recursos sonoros aparecem de forma não padronizada nos poemas.
} 


\subsection{3}

A primeira etapa em relação ao estudo de caso 1

\begin{tabular}{|c|c|c|c|}
\hline Nível/ Plano & Categorias & Anotadores & Resultados \\
\hline $\begin{array}{c}\text { Semântico- } \\
\text { lexical }\end{array}$ & SL1 & JC e AD & A1 \\
\hline Formal & F & JC, AD e EF & B \\
\hline $\begin{array}{c}\text { Recursos } \\
\text { sonoros }\end{array}$ & RS & JC, AD e EF & C \\
\hline
\end{tabular}

\subsection{4}

\section{Após a reformulação das categorias SL1}

\begin{tabular}{|c|c|c|c|}
\hline Nível/ Plano & Categorias & Anotadores & Resultados \\
\hline $\begin{array}{c}\text { Semântico- } \\
\text { lexical }\end{array}$ & SL2 & JC e EF & A2 \\
\hline Formal & F & JC, AD e EF & B \\
\hline $\begin{array}{c}\text { Recursos } \\
\text { sonoros }\end{array}$ & RS & JC, AD e EF & C \\
\hline
\end{tabular}

Quanto ao estudo de caso 1, todos os três anotadores - JC, AD e EF utilizaram as mesmas categorias - F e RS - para anotarem o nível formal e o plano de recursos sonoros, respectivamente. Por isso, comparo as três anotações do nível formal, gerando os resultados B, e as três anotações do plano de recursos sonoros, gerando os resultados $\mathrm{C}$.

Já em relação ao nível semântico, JC e AD utilizaram as categorias SL1 que, após sofrerem reformulações, passaram a ser denominadas categorias SL2, e foram utilizadas por JC e EF. Portanto, comparo as anotações de JC e AD, gerando os resultados A1 e, separadamente, comparo as anotações de $\mathrm{JC}$ e $\mathrm{EF}$, gerando os resultados $\mathrm{A} 2$.

\subsection{5}

A primeira etapa em relação ao estudo de caso 2: após a reformulação das categorias SL2 


\begin{tabular}{|c|c|c|c|}
\hline Nível/ Plano & Categorias & Anotadores & Resultados \\
\hline $\begin{array}{c}\text { Semântico- } \\
\text { lexical }\end{array}$ & SL3 & JC, AS e MM & $\mathrm{D}$ \\
\hline Formal & $\mathrm{F}$ & JC, AS e MM & $\mathrm{E}$ \\
\hline $\begin{array}{c}\text { Recursos } \\
\text { sonoros }\end{array}$ & RS & JC, AS e MM & $\mathrm{F}$ \\
\hline
\end{tabular}

Quanto ao estudo de caso 2, todos os três anotadores - JC, AS e MM utilizaram as mesmas categorias - SL3, F e RS - para anotarem os níveis semânticolexical, formal e o plano de recursos sonoros, respectivamente. Por isso, comparo as três anotações do nível semântico-lexical, gerando os resultados D; aquelas do nível formal, gerando os resultados E; e também as do plano de recursos sonoros, gerando os resultados $\mathrm{F}$.

\section{5}

\section{Segunda etapa}

Primeiramente, após comparar anotações do nível formal e do plano de recursos sonoros de um mesmo estudo de caso, montei gabaritos - as anotações finais do nível formal e do plano de recursos sonoros desse determinado estudo de caso. Quanto ao nível semântico-lexical, o gabarito foi feito utilizando as categorias SL4, fruto das últimasreformulações das categorias SL, a fim de anotar o determinado estudo de caso.

Em seguida analisei, através de duas verificações, esses gabaritos, utilizando a metodologia de Britto (2002; 2006c), com algumas observações adicionais. Objetivase, por meio de tal metodologia, verificar se os aspectos mais relevantes dos níveis métrico, rimático, semântico-lexical e do plano de recursos sonoros (aliterações, assonâncias e recursos afins) dos poemas originais foram recriados nas traduções. Complemento essa metodologia levando em conta mais alguns fatores, dispostos abaixo, nos Procedimentos da segunda etapa.

\subsection{1}

\section{Procedimentos da segunda etapa}


Primeira verificação:

(a) aspectos estruturantes:

( a.1 )verifiquei se há categorias SL que priorizam a reprodução de características formais do original, tais como manutenção do contrato métrico em português que corresponda àquele do poema em inglês; e/ou manutenção do esquema rimático do original.

(a.2) verifiquei se o tradutor prioriza reproduzir a forma poética do original: um soneto deve ser traduzido por um soneto, por exemplo.

(a.3) verifiquei se os esquemas rimáticos do original e da tradução apresentam tanto rimas completas quanto incompletas.

(a.4) verifiquei se há características formais, no original, que se articulam de modo evidente com o nível semântico-lexical; e

(a.5) se havia, se o tradutor priorizou tentar reproduzi-las na tradução.

Segunda verificação:

(b) aspectos fonológicos

( b.1 ) após a verificação (a.1), reuni as categorias SL que não priorizam a reprodução de características formais do original. Assim, verifiquei se elas priorizam, então, a reprodução de características fonológicas do original como, por exemplo, a formação de uma sequência rica de assonâncias em português que corresponda a uma sequência rica de aliterações do poema em inglês.

(b.2)verifiquei se havia recursos sonoros, no original, que se articulam de modo evidente com o nível semântico-lexical; e

(b.3) se havia, se o tradutor priorizoutentar reproduzi-los na tradução.

Obs3: Como os recursos sonoros dos estudos de caso não aparecem de forma padronizada nos poemas em inglês, julgo suficiente verificar se o tradutor tentou reproduzir os recursos do original que mantêm uma relação notável com o plano do sentido.

\subsection{2}




\section{A segundaetapa em relação ao estudo de caso 2: após a reformulação das categorias SL3}

\begin{tabular}{|c|c|c|}
\hline $\begin{array}{c}\text { Aspectos } \\
\text { poéticos }\end{array}$ & Categorias & Resultados \\
\hline $\begin{array}{c}\text { Estruturantes } \\
\text { (verificação: } \\
\text { a.1) }\end{array}$ & SL4 & \\
\hline $\begin{array}{c}\text { Estruturantes } \\
\text { (verificações } \\
\text { a.2, a.3,a.4, a.5 }\end{array}$ & $\mathrm{F}$ & $\mathrm{J}$ \\
\hline $\begin{array}{c}\text { Fonológicos } \\
\text { (verificações: }\end{array}$ & & \\
b.1,b.2,b.3) & $\mathrm{RS}$ & $\mathrm{M}$ \\
\hline
\end{tabular}

Em relação ao nível formal, comparei as anotações feitas por JC, AS e MM, para chegar a uma anotação final, a um gabarito. Cheguei a esse gabarito levando em conta tudo o que já estudei sobre versificação inglesa e portuguesa, e também as categorias F. Quanto ao plano de recursos sonoros, comparei as anotações de JC, AS e MM para, também, chegar a uma anotação final, a um gabarito. Cheguei a esse gabarito levando em conta tudo o que já estudei sobre recursos sonoros, e também as categorias RS. Já em relação ao nível semântico-lexical, utilizei as categorias SL4, fruto das últimas reformulações das categorias SL, para anotar o estudo de caso 2 e, assim, produzir um gabarito. Com os gabaritos prontos, passei às verificações previstas para a segunda etapa.

\section{6}

\section{Terceira etapa}

Através da comparação dos resultados G, H, I, referentes à tradução de Ivo Barroso; com os resultados $\mathrm{J}, \mathrm{L}, \mathrm{M}$, concernentes à tradução de Jorge Wanderley, produzielementos para uma possível avaliação de traduções de poesia: entre essas duas traduções do soneto 130 de Shakespeare, verificar qual seria a mais fiel ao original. 


\subsection{1}

\section{Procedimentos da terceira etapa}

Primeira comparação: resultados G e J. Comparei:

(a) o número de ocorrências de estratégias tradutórias que aparentemente priorizam reproduzir aspectos formais do original; e

(b) o número de ocorrências de estratégias tradutórias que aparentemente não priorizam reproduzir aspectos formais do original.

Segunda comparação: resultados H e L.

(c) verifiquei se cada tradução reproduziu ou não a forma poética do original.

(d) Comparei:

(d.1) o número de rimas incompletas;

(d.2) o número de casos em que o tradutor prioriza reproduzir aspectos formais do original que se articulam de modo evidente com o nível semântico-lexical; e

(d.3) o número de casos em que o tradutor não prioriza reproduzir aspectos formais do original que se articulam de modo evidente com o nível semântico-lexical.

Terceira comparação: resultados I e M. Comparei:

(e) o número de ocorrências de estratégias tradutórias que aparentemente também não priorizam reproduzir aspectos fonológicos do original;

(f) o número de casos em que o tradutor prioriza reproduzir aspectos fonológicos do original que se articulam de modo evidente com o nível semântico-lexical; e

(g) o número de casos em que o tradutor não prioriza reproduzir aspectos fonológicos do original que se articulam de modo evidente com o nível semântico-lexical. 


\section{Resultados da primeira etapa}

\section{1}

\section{Resultados A1}

\subsection{1}

\section{Anotação feita por JC}

My mistress' eyes are nothing like the sun;

\{Coral is far more red $\}^{\text {inv1 }}$ than her lips' red; If snow be white, why then her $\{\text { breasts }\}^{\text {asem } 1}$

[are dun;

$\{\text { If hairs be wires }\}^{\text {omi }}$, black wires grow on her [head.

I have seen roses damasked, red and white, But no such roses see I in her cheeks; And in some perfumes is there more $\left[\{\text { delight }\}^{\text {asem2 }}\right.$

Than in the breath that from my mistress [reeks.

I love to hear her speak, \{yet well I know $\}^{\text {asem3 }}$

\{That music hath a far more pleasing

$\{\text { I grant I never saw a goddess go }\}^{\text {inv3 }}$; [sound ${ }^{\text {inv2 }}$

My mistress when she walks treads on the

[ground.

And yet, by heaven, I think my love as rare As $\}^{\text {asem } 4}$ any she belied with false
Seus olhos nada têm de um sol \{que arda $\}^{\text {acrl }}$ $\{\text { E mais rubro é o coral }\}^{\text {inv1 }}$ que sua boca: Se a neve é branca, sua $\{\text { tez }\}^{\text {aseml }}$ é parda;

São fios negros seu cabelo $\{\text { em touca }\}^{\text {acr2 }}$.

Vi rosas mesclas de rubor e alvura, Mas tais rosas não vejo em sua face. Sei de perfumes que têm mais $\{\text { doçura }\}^{\text {asem2 }}$ Que o hálito da amada evolasse.

Amo ouvi-la falar, \{porém insisto $\}^{\text {asem } 3}$

$\left\{\right.$ Que mais me agrada ouvir uma canção ${ }^{\text {inv2 }}$. $\{\text { De deusas nunca devo o andar ter visto }\}^{\text {inv3 }}$

Minha amante ao andar pisa no chão.

No entanto, pelos céus, acho-a \{ mais rara Do que $\}^{\text {asem } 4}$ a mulher que em falso se [compara. 
Ao todo anotei 10 ocorrências de categorias. Separando e contabilizando as categorias, temos: 2 acréscimos, 3 inversões, 4 alterações semânticas, e 1 omissão, como ilustra a tabela A:

TABELA A:

\begin{tabular}{|c|c|}
\hline Categoria & $\begin{array}{c}\mathbf{N}^{\mathbf{0}} \text { de } \\
\text { ocorrências }\end{array}$ \\
\hline Acréscimo & 2 \\
\hline Inversão & 3 \\
\hline Alteração semântica & 4 \\
\hline Omissão & 1 \\
\hline
\end{tabular}

\section{1 .2}

\section{Anotação feita por AD}

My mistress' eyes are nothing like the sun; \{Coral is far more red $\}^{\text {inv1 }}$ than her lips' red; If snow be white, why then her $\left\{\right.$ breasts ${ }^{\text {asem1 }}$ [are dun;

$\{\text { If hairs be wires, }\}^{\text {omi }}\{$ black wires grow on $[\text { her head }\}^{\text {asem2 }}$

I have seen roses damasked, red and white, But no such roses see I in her cheeks;

And in some perfumes is there more

Than in the breath that from my mistress

$$
\left[\{\text { delight }\}^{\text {asem3 }}\right.
$$

[reeks.

I love to hear her speak, \{yet well I know $\}^{\text {asem4 }}$

\{That music hath a far more pleasing

$\{\text { I grant I never saw a goddess go; }\}^{\text {inv3 }}$ [sound; ${ }^{\text {inv2,asem5 }}$ My mistress when she walks treads on the [ground.

And yet, by heaven, I think my love \{as rare As $\}^{\text {asem6 } 6}$ any she belied with false compare.
Seus olhos nada têm de um sol \{que arda $\}^{\text {acrl }}$ $\{\text { E mais rubro é o coral }\}^{\text {inv1 }}$ que sua boca: Se a neve é branca, sua $\{\text { tez }\}^{\text {asem1 }}$ é parda;

$\{\text { São fios negros seu cabelo em touca }\}^{\text {asem2 }}$.

Vi rosas mesclas de rubor e alvura, Mas tais rosas não vejo em sua face. $\{\text { Sei de }\}^{\text {acr2 }}$ perfumes que têm mais Que o hálito da amada evolasse.

$$
\left[\{\text { doçura }\}^{\text {asem } 3}\right.
$$

Amo ouvi-la falar, \{porém insisto $\}^{\text {asem4 }}$

\{Que mais me agrada ouvir uma [canção. $]^{\text {inv2,asem5 }}$

$\{$ De deusas nunca devo o andar ter visto $[-]^{\text {inv3 }}$

Minha amante ao andar pisa no chão.

No entanto, pelos céus, acho-a \{ mais rara Do que $\}^{\text {asem6 }}$ a mulher que em falso se

[compara. 
Ao todo, $\mathrm{AD}$ anotou 12 ocorrências de categorias, sendo 2 acréscimos, 3 inversões, 1 omissão e 6 alterações semânticas, como ilustra a tabela B:

TABELA B:

\begin{tabular}{|c|c|}
\hline Categoria & $\begin{array}{c}\mathbf{N}^{\mathbf{0}} \text { de } \\
\text { ocorrências }\end{array}$ \\
\hline Acréscimo & 2 \\
\hline Inversão & 3 \\
\hline Alteração semântica & 6 \\
\hline Omissão & 1 \\
\hline
\end{tabular}

\section{1 .3}

\section{Comparação das anotações}

TABELA C:

\begin{tabular}{|c|c|}
\hline Anotadoras & Número de ocorrências anotadas \\
\hline JC & 10 \\
\hline AD & 12 \\
\hline
\end{tabular}

Aqui, notamos que $\mathrm{AD}$ anotou duas ocorrências a mais que eu. Isso se deve às duas alterações semânticas que somente AD anotou (comento tais discordâncias após a Tabela D).

TABELA D:

Anotadoras

\begin{tabular}{|c|c|}
\hline Anotadoras & $\begin{array}{c}\text { Total de ALTERAÇÕES } \\
\text { SEMÂNTICAS }\end{array}$ \\
\hline
\end{tabular}




\begin{tabular}{|c|c|}
\hline JC & 4 \\
\hline $\mathrm{AD}$ & 6 \\
\hline
\end{tabular}

Quanto às alterações semânticas, houve duas discordâncias:alterações semânticas anotadas somente por AD:

1. Primeira estrofe, quarto verso:

(a) AD: alteração semântica de "black wires grow on her head" (Fios negros crescem em sua cabeça) para"São fios negros seu cabelo em touca".

(b) JC: nesse trecho, apenas anotei "em touca" como acréscimo.

2. Terceira estrofe, segundo verso:

(a) AD: inversão e alteração semântica em "That music hath a far more pleasing sound" (Quemúsica tem um som bem mais agradável) para "Que mais me agrada ouvir uma canção".

(b) JC: nesse trecho, anotei apenas INVERSÃO.

TABELA E:

\begin{tabular}{|c|c|}
\hline Anotadoras & Total de OMISSÕES \\
\hline JC & 1 \\
\hline AD & 1 \\
\hline
\end{tabular}

Quanto às omissões, não houve discordâncias.

\section{TABELA F:}

\begin{tabular}{|c|c|}
\hline Anotadoras & Total de ACRÉSCIMOS \\
\hline JC & 2 \\
\hline AD & 2 \\
\hline
\end{tabular}

Quanto aos acréscimos, houve duas discordâncias:

(a) Discordância:

a.1. AD: segunda estrofe, terceiro verso: acréscimo de "Sei de". Eu não anotei nada nessa estrofe.

a.2. JC: primeira estrofe, quarto verso: acréscimo de "em touca". AD anotou alteração semântica de "black wires grow on her head" (Fios negros crescem em sua cabeça) para“São fios negros seu cabelo em touca". 
TABELA G:

\begin{tabular}{|c|c|}
\hline Anotadoras & Total de INVERSÕES \\
\hline JC & 3 \\
\hline AD & 3 \\
\hline
\end{tabular}

Quanto às inversões, não houve discordâncias.

TABELA H:

\begin{tabular}{|c|c|}
\hline Total de concordâncias & 9 \\
\hline Total de discordâncias & 4 \\
\hline Categorias que levaram a mais & OMISSÃO \\
concordâncias & $\mathrm{e}$ \\
INVERSÃO \\
\hline Categorias que levaram a mais \\
discordâncias & ALTERAÇÃO SEMÂNTICA \\
& e \\
Categorias que não foram encontradas & DUPLICAÇÃO, ENXUGAMENTO, \\
& EXPLICITAÇÃO e DESLOCAMENTO \\
\hline
\end{tabular}

Em relação às 4 discordâncias, 2 foram quanto a alterações semânticas e 2 referentes aos acréscimos.

Em relação às categorias que levaram a mais concordâncias, observamos que OMISSÃO e INVERSÃO foram as duas únicas categorias que apresentaramsomente convergências. Já quanto às categorias que levaram a mais discordâncias, notamos que ALTERAÇÃO SEMÂNTICA e ACRÉSCIMO foram as duas únicas categorias que apresentam alguma divergência nas anotações. As seguintes categorias: DUPLICAÇÃO, ENXUGAMENTO, EXPLICITAÇÃO e DESLOCAMENTO não foram encontradas por nenhuma das duas anotadoras.

\section{1 .4}

Discussão dos resultados 
De acordo com a Tabela $\mathrm{H}$, as categorias que levaram a mais concordâncias foram OMISSÃO e INVERSÃO. Creio que isso tenha ocorrido devido à maior facilidade de detectar tais categorias, pois suas explicações apresentam uma contraparte formal: omissão de palavras e inversão da ordem de palavras, respectivamente.

Ainda nessa tabela, observamos que as categorias que levaram a mais discordâncias foram ALTERAÇÃO SEMÂNTICA e ACRÉSCIMO. Quanto às divergências em relação à categoria alteração semântica, podemos dizer que elas ocorreram devido às explicações vagas dessa categoria. Diferentes anotadores podem discordar muito quanto ao que seria uma alteração de elementos semânticos, e deve ter sido isso o que aconteceu no caso em questão. AD considerou que na tradução de "black wires grow on her head" (Fios negros crescem em sua cabeça) para"São fios negros seu cabelo em touca" (primeira estrofe, quarto verso), e de "That music hath a far more pleasing sound"(Quemúsica tem um som bem mais agradável) para "Que mais me agrada ouvir uma canção" (terceira estrofe, segundo verso) houve alteração de elementos semânticos. E, para mim, em nenhuma dessas traduções ocorreu tal alteração. Essas duas discordâncias me motivaram a reformular as explicações da categoria ALTERAÇÃO SEMÂNTICA, a fim de evitar vagueza e, assim, divergências futuras.

Apesar das explicações da categoria ACRÉSCIMO terem um complemento formal, elafoi uma das categorias que causou mais divergências. As explicações dessa categoria, por mais claras que pensei que estivessem, causaram discordâncias: somente ADanotou "Sei de" (segunda estrofe, terceiro verso) como ACRÉSCIMO; e somente eu anotei "em touca" (primeira estrofe, quarto verso) com essa mesma categoria.

\section{2}

Resultados A2

\section{2 .1}

\section{Anotação feita por JC}

My mistress' eyes are nothing like the sun; Coral is far more red than her lips' red; If snow be white, why then her $\{\text { breasts }\}^{\text {asem1 }}$ [are dun; $\{\text { If hairs be wires }\}^{\text {omi }}$, black wires grow on her
Seus olhos nada têm de um sol \{que arda $\}^{\text {acrl }}$ E mais rubro é o coral que sua boca:

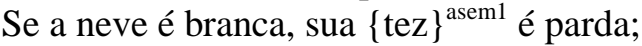

São fios negros seu cabelo $\{\text { em touca }\}^{\text {acr2 }}$. 


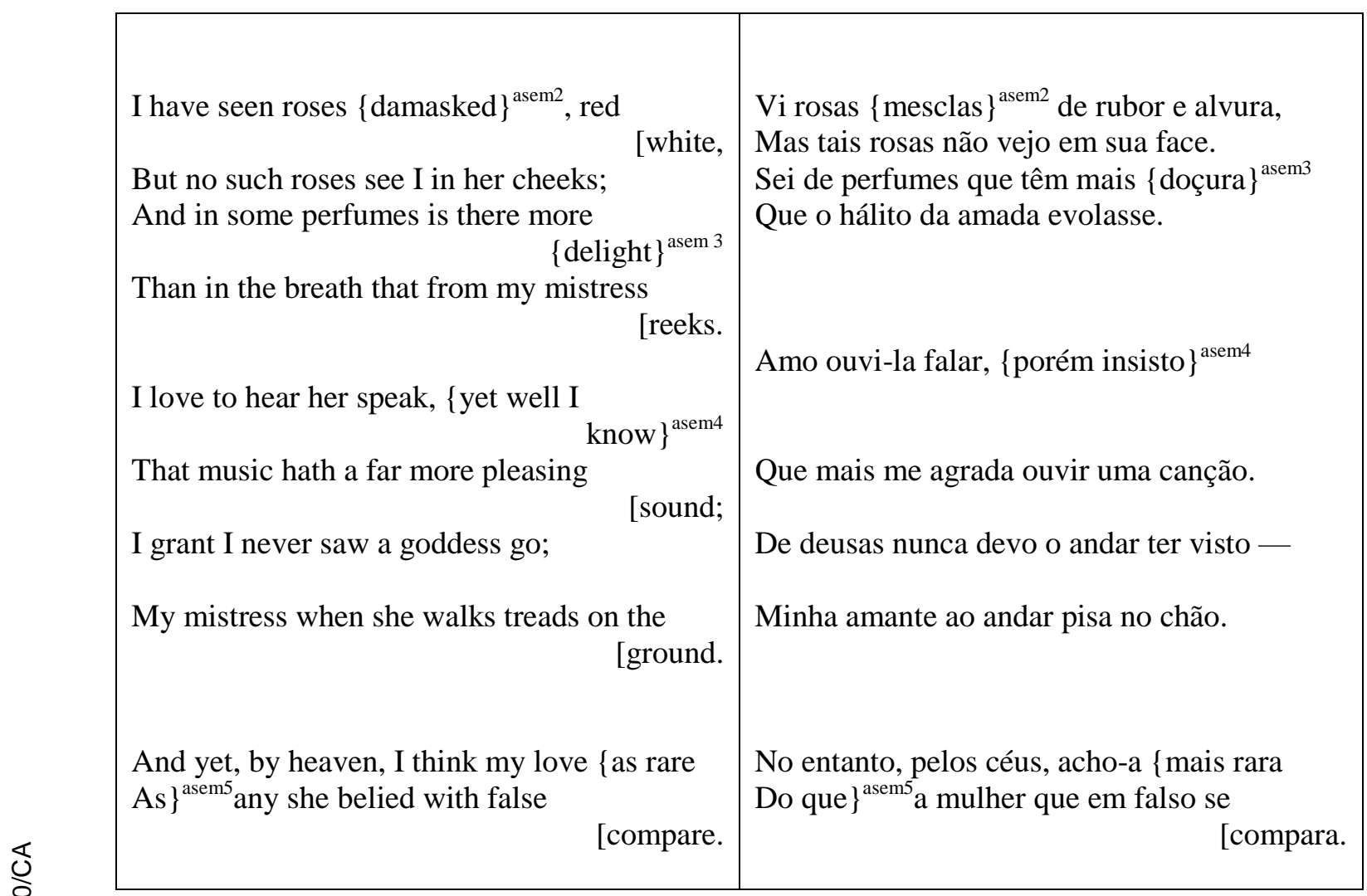

Ao todo anotei 8 ocorrências de categorias. Separando e contabilizando as categorias, temos: 2 acréscimos, 5 alterações semânticas, e 1 omissão, como ilustra a tabela A:

TABELA A:

\begin{tabular}{|c|c|}
\hline Categoria & $\begin{array}{c}\mathbf{N}^{\mathbf{0}} \mathbf{d e} \\
\text { ocorrências }\end{array}$ \\
\hline Acréscimo & 2 \\
\hline Alteração semântica & 5 \\
\hline Omissão & 1 \\
\hline
\end{tabular}

\subsection{2}

\section{Anotação feita por EF}




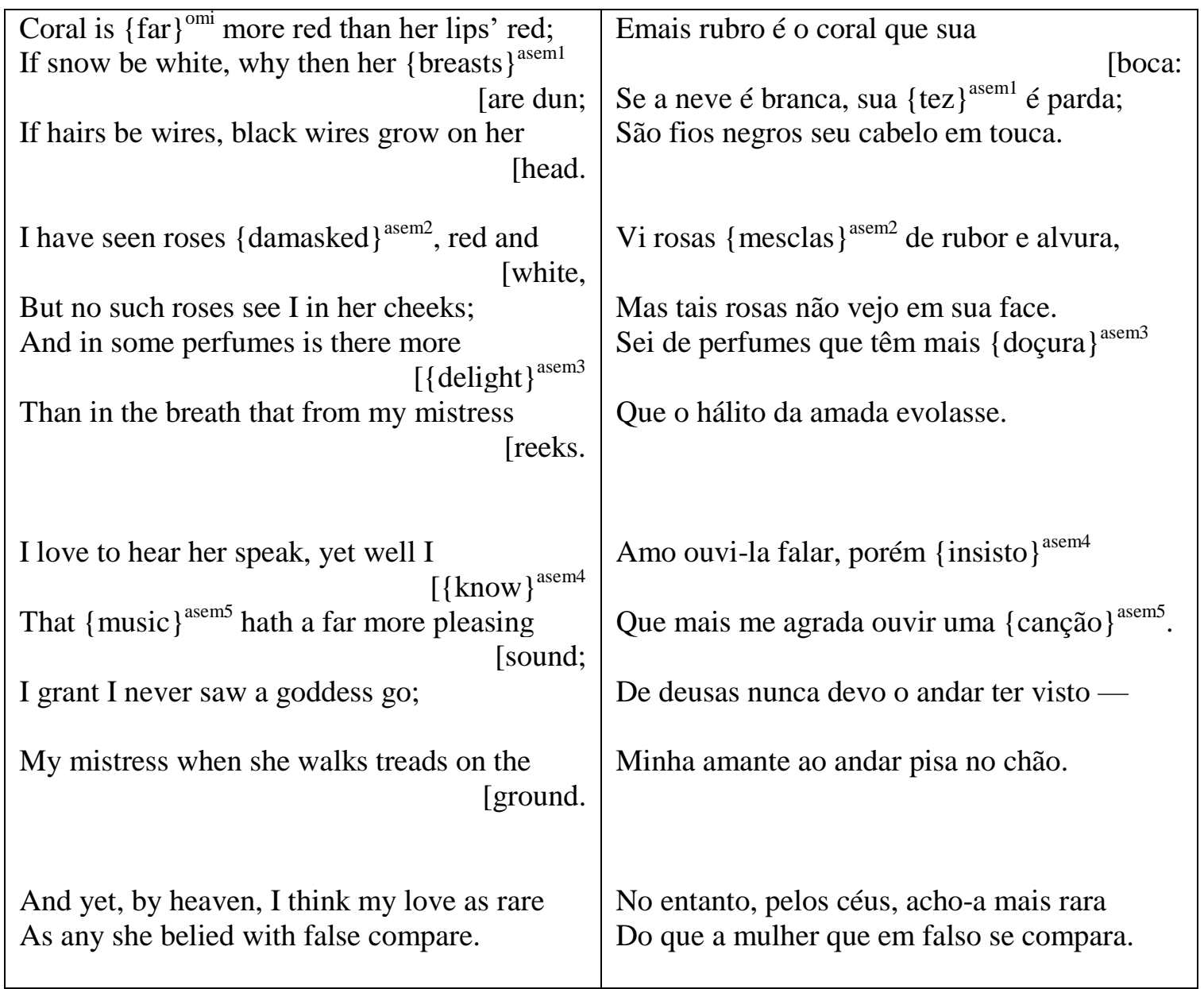

Ao todo, EF anotou 7 ocorrências de categorias, sendo 1 acréscimo, 1 omissão e 5 alterações semânticas, como ilustra a tabela B:

TABELA B:

\begin{tabular}{|c|c|}
\hline Categoria & $\begin{array}{c}\mathbf{N}^{\mathbf{0}} \text { de } \\
\text { ocorrências }\end{array}$ \\
\hline Acréscimo & 1 \\
\hline Alteração semântica & 5 \\
\hline Omissão & 1 \\
\hline
\end{tabular}

\section{2 .3}

\section{Comparação das anotações}


TABELA C:

\begin{tabular}{|c|c|}
\hline Anotadores & Número de ocorrências anotadas \\
\hline JC & 8 \\
\hline EF & 7 \\
\hline
\end{tabular}

Aqui, notamos que eu anotei uma ocorrência a mais que EF. Veremos a seguir, neste subcapítulo, as discordâncias que aconteceram nessas ocorrências anotadas.

TABELA D:

\begin{tabular}{|c|c|}
\hline Anotadores & $\begin{array}{c}\text { Total de ALTERAÇÕES } \\
\text { SEMÂNTICAS }\end{array}$ \\
\hline JC & 5 \\
\hline EF & 5 \\
\hline
\end{tabular}

Quanto às alterações semânticas, houve duas discordâncias:

Uma alteração semântica foi anotada somente por mim:

1. Dístico final: de "as rare/ As" (tão rara quanto) para "mais rara/ Do que".

Uma alteração semântica foi anotada somente por EF:

3. Terceira estrofe, segundo verso: de "music" (música) para "canção".

TABELA E:

\begin{tabular}{|c|c|}
\hline Anotadores & Total de OMISSÕES \\
\hline JC & 1 \\
\hline EF & 1 \\
\hline
\end{tabular}

Quanto às omissões, houve duas discordâncias:

Uma omissão foi anotada somente por mim:

Primeira estrofe, quarto verso: "If hairs be wires" (Se cabelos são fios).

Uma omissão foi anotada somente por EF:

Primeira estrofe, segundo verso: "far" (bem) 
TABELA F:

\begin{tabular}{|c|c|}
\hline Anotadores & Total de ACRÉSCIMOS \\
\hline JC & 2 \\
\hline EF & 1 \\
\hline
\end{tabular}

Quanto aos acréscimos, houve uma discordância:

(a) Discordância: primeira estrofe, quarto verso: acréscimo anotado somente por mim: "em touca".

TABELA G:

\begin{tabular}{|c|c|}
\hline Total de concordâncias & 5 \\
\hline Total de discordâncias & 5 \\
\hline Categorias que levaram a mais & e \\
concordâncias & ACRÉSCIMO \\
\hline Categorias que levaram a mais & OMISSÃO SEMÂNTICA \\
discordâncias & \\
\hline Categorias que não foram encontradas & TODAS FORAM ENCONTRADAS \\
\hline
\end{tabular}

Em relação às 5 discordâncias, 2 foram quanto a alterações semânticas, 2 em relação às omissões, e 1 referente aos acréscimos.

Quanto às categorias que levaram a mais concordâncias, observamos que ALTERAÇÃO SEMÂNTICA e ACRÉSCIMO foram as duas únicas categorias que apresentam alguma convergência nas anotações.

Já quanto às categorias que levaram a mais discordâncias, notamos que OMISSÃO foi a única que apresentou somente divergências. Nessa análise observamos, também, que todas as três categorias do guia SL2 foram encontradas por ambos os anotadores. 


\section{2 .4}

\section{Discussão dos resultados}

De acordo com a Tabela $G$, as categorias que levaram a mais concordâncias foram ALTERAÇÃO SEMÂNTICA e ACRÉSCIMO. Isso é curioso pois, na comparação das anotações feitas por mim e por $\mathrm{AD}$, em que levamos em conta o guia SL1 para anotarmos o estudo de caso 1, essas mesmas categorias foram as que levaram a mais discordâncias. Creio que essa evolução pode ter ocorrido devido ao refinamento de tais categorias do guia SL1, que teve por finalidade a busca por maiores concordâncias em futuras anotações.

Ainda nessa tabela, observamos que a categoria que levou a mais discordâncias foi OMISSÃO. Novamente, um fato curioso: na comparação das anotações feitas por mim e por AD, em que utilizamos o guia SL1 para anotarmos o estudo de caso 1, essa mesma categoria foi uma das que levou a mais concordâncias. Na época, isso se deveu ao fato da maior facilidade em detectar essa categoria, pois suas explicações apresentam uma contraparte formal: omissão de palavras. No entanto, agora, podemos considerar que, talvez, OMISSÃO precise de reformulações. Na omissão que somente EF anotou (primeira estrofe, segundo verso) "Coral is $\{f a r\}{ }^{\text {omi }}$ more red than her lips" red" (original) / "E mais rubro é o coral que sua boca" (tradução), far, aqui, é um advérbio de intensidade: far more red, seria, em português, "bem mais rubro". Ao reler asexplicações da categoria em questão, notei que elas não incluem e nem excluem omissões de advérbios.Creio que, para EF, essa "intensidade" não está presente na tradução e, dessa forma, ele anotou esse far como omissão. Temos uma omissão que somente eu anotei: "\{If hairs be wires\} $\}^{\text {omi }}$, black wires grow on her head" (original)/ "São fios negros seu cabelo em touca." (tradução) - primeira estrofe, quarto verso: como as explicações de OMISSÃO incluem omissões de elementos semânticos presentes em orações, e os elementos semânticos presentes em "If hairs be wires" (Se cabelos são fios) não estão presentes na tradução, anotei a omissão de tal oração. No cômputo geral, quanto à categoria OMISSÃO, creio que ela necessite de refinamento para, ao menos, incluir em suas explicações a omissão de elementos semânticos presentes em advérbios.

Quanto às anotações de alterações semânticas e de acréscimos, tivemos algumas divergências também. As explicaçõesde ALTERAÇÃO SEMÂNTICA incluem alteração de elementos semânticos em um adjetivo. Assim, anotei o seguinte trecho 
como alteração semântica(dístico final, primeiro e segundo verso): "as rare/ As" (tão rara quanto) para "mais rara/ Do que", pois acredito que houve alteração de elementos semânticos na tradução do trecho, que contém o adjetivo "rare": no original, "rara" está em comparação de igualdade, enquanto que em "mais rara/ Do que" , "rara" está comparação de superioridade. Somente eu procedi dessa forma. Temos uma alteração semântica que somente EF anotou (terceira estrofe, segundo verso): a tradução de "music" por "canção". Eu não anotei nada aqui, pois, de acordo com as explicações de ALTERAÇÃO SEMÂNTICA, consideramos que há alteração de elementos semânticos do original quando a tradução não utiliza sinônimos, hipônimos ou hiperônimos. No caso em questão, acredito que o substantivo "music" (música) tenha sido traduzido por um hipônimo, "canção", dessa forma, não vejo alteração semântica na tradução desse trecho. Encontramos discordância,também, na anotação do acréscimo de "em touca" (primeira estrofe, quarto verso), feita somente por mim. As explicações de ACRÉSCIMO incluem acréscimo de elementos semânticos que não estão presentes na estrofe do original, através de, por exemplo, um substantivo, e é isso que ocorre nesse caso.Além disso, as explicações da categoria em questão não levam em consideração acréscimos de preposições isoladas, porém, em "em touca", a preposição “em" está acompanhada do substantivo "touca". Assim, creio que em "If hairs be wires, black

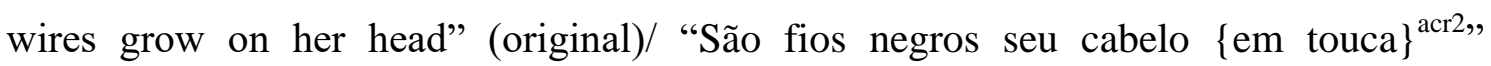
(tradução), temos acréscimo.

\section{3}

Resultados B

\subsection{1}

\section{Anotação feita por JC}

\begin{tabular}{|c|c|}
\hline$-1|-1|-1|-1|-1 \mid$ & $-1-1-1-1-1-$ \\
\hline $\begin{array}{l}\text { My mistress' eyes are nothing like the sun; } a \text { J-J-J-J- } \\
\text { J }\end{array}$ & $\begin{array}{l}\text { Seus olhos nada têm de um sol que arda } a \\
2-4-6-8-10\end{array}$ \\
\hline $\begin{array}{l}/-|-/|-\quad /|--| / \quad / \mid \\
\text { Coral is far more red than her lips, red; } b \text { T-J-J-P-E }\end{array}$ & $\begin{array}{l}-\quad / \quad l \quad l \quad-\quad / \quad-\quad /-/ \text { - } \\
\text { E mais rubro é o coral que sua boca: }\end{array}$ \\
\hline
\end{tabular}




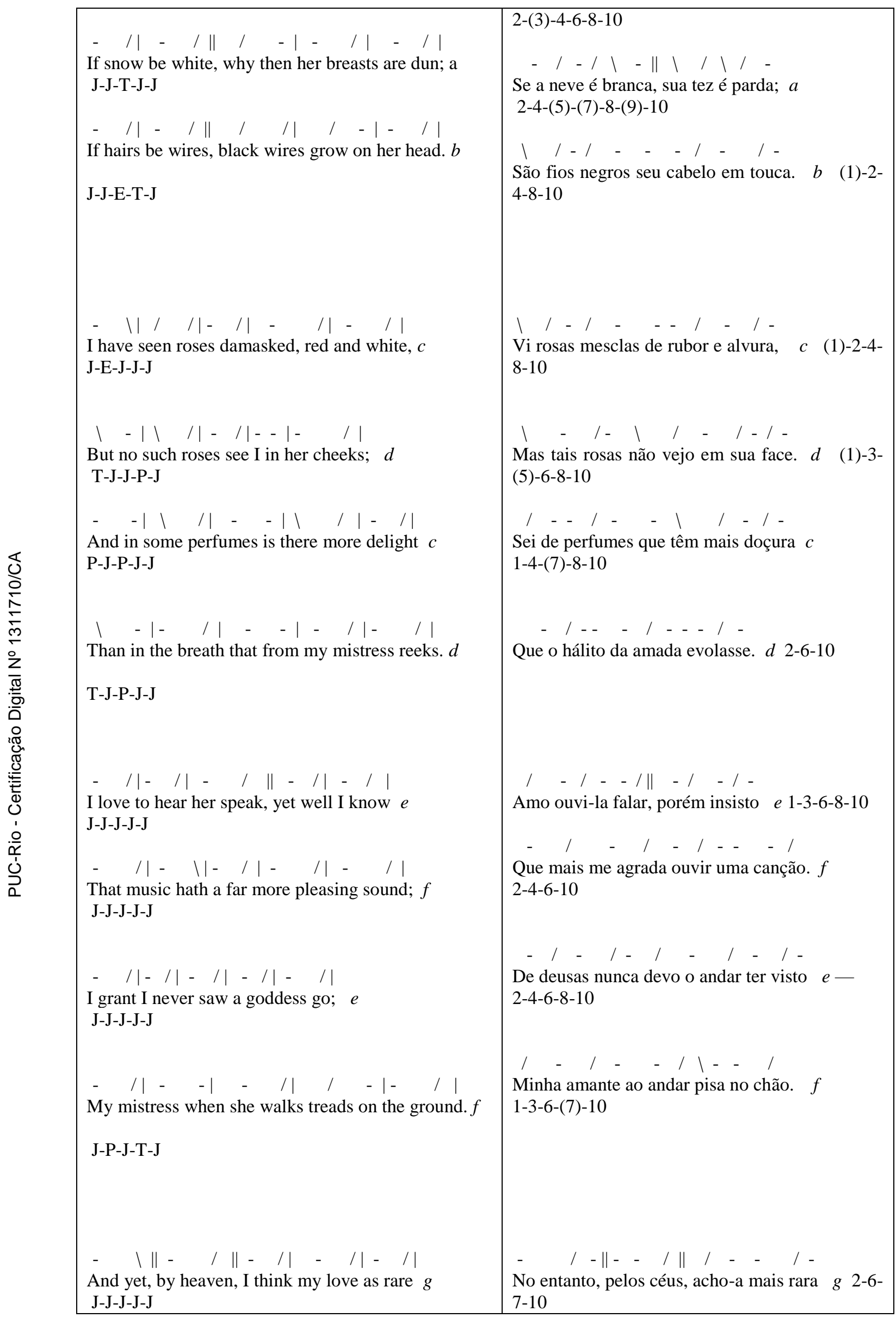


$-|1--|-1|-1|-1 \mid$

As any she belied with false compare. $g$ J-P-J-J-J
Do que a mulher que em falso se compara. $g$ 46-10

\section{3 .2}

\section{Anotação feita por AD}

\begin{tabular}{|c|c|}
\hline$-1|-1 / 1 / 1|-1|-1|$ & $-1-1-1-1-1-$ \\
\hline $\begin{array}{l}\text { My mistress' eyes are nothing like the sun; } a \text { J-J- } \\
\text { E-J-J }\end{array}$ & $\begin{array}{l}\text { Seus olhos nada têm de um sol que arda } a \\
2-4-6-8-10\end{array}$ \\
\hline $1-|-1|-1|-1| 1 / 1 \mid$ & $-111 / 2-1 \quad-\quad--1-$ \\
\hline $\begin{array}{l}\text { Coral is far more red than her lips' red; } b \text { T-J-J-J- } \\
\text { E }\end{array}$ & $\begin{array}{l}\text { E mais rubro é o coral que sua boca: } b \\
2-(3)-4-6-10\end{array}$ \\
\hline$-1|-1| 1 /-|-1|-1 \mid$ & $-11 / \ldots-211 /$ \\
\hline $\begin{array}{l}\text { If snow be white, why then her breasts are dun; } a \\
\text { J-J-T-J-J }\end{array}$ & $\begin{array}{l}\text { Se a neve é branca, sua tez é parda; } a \\
2-(3)-4-8-(9)-10\end{array}$ \\
\hline \begin{tabular}{ll|ll|ll|ll|ll|}
- & 1 & - & 1 & 1 & 1 & 1 & -1 & - & 1
\end{tabular} & $1 \mid-1-1-1-1-$ \\
\hline $\begin{array}{l}\text { If hairs be wires, black wires grow on her head. } b \\
\text { J-J-E-T-J }\end{array}$ & $\begin{array}{l}\text { São fios negros seu cabelo em touca. } b \\
1-(2)-4-6-8-10\end{array}$ \\
\hline $1-1 / 1 /-1|-1|-1 \mid$ & $11-1-1-1-1-$ \\
\hline $\begin{array}{l}\text { I have seen roses damasked, red and white, } c \text { T-E- } \\
\text { J-J-J }\end{array}$ & $\begin{array}{l}\text { Vi rosas mesclas de rubor e alvura, } c 1-(2)-4-8- \\
10\end{array}$ \\
\hline$-1|-1|-1|1-|-1 \mid$ & $-11-1 /--1-$ \\
\hline But no such roses see I in her cheeks; $d$ J-J-J-T-J & $\begin{array}{l}\text { Mas tais rosas não vejo em sua face. } d 2-(3)-(5)- \\
6-10\end{array}$ \\
\hline \begin{tabular}{llllll|lllll}
- & -1 & 1 & -1 & 1 & -1 & 1 & 1 & 1 & - & 1
\end{tabular} & \\
\hline $\begin{array}{l}\text { And in some perfumes is there more delight } c \text { P- } \\
\text { T-T-E-J }\end{array}$ & $\begin{array}{l}/ \quad-\quad-\quad-\quad-\quad \mid \quad / \quad-/- \\
\text { Sei de perfumes que têm mais doçura } \\
1-4-(7)-8-10\end{array}$ \\
\hline Than in the breath that from my mistress reeks. $d$ & $-1--1-$ \\
\hline
\end{tabular}




\begin{tabular}{|c|c|}
\hline T-J-J-J-J & Que o hálito da amada evolasse. $d$ 2-6-10 \\
\hline $\begin{array}{l}-/|-| l|l|-|l| l \mid \\
\text { I love to hear her speak, yet well I know e J-J-J-J- } \\
\text { J }\end{array}$ & $\begin{array}{l}\text { I }-/--/ \quad-/ \quad-/- \\
\text { Amo ouvi-la falar, porém insisto e (1)-3-6-8-10 }\end{array}$ \\
\hline $\begin{array}{l}-\quad /|-\quad /|-/|-\quad /|-\quad /|| \\
\text { That music hath a far more pleasing sound; } f \text { J-J- } \\
\text { J-J-J }\end{array}$ & $\begin{array}{l}-\quad / \quad-\quad /-1---1 \\
\text { Que mais me agrada ouvir uma canção. } f \\
2-4-6-10\end{array}$ \\
\hline $\begin{array}{l}-\quad /|-/|-/|-||-| \mid \\
\text { I grant I never saw a goddess go; } e \\
\text { J-J-J-J-J }\end{array}$ & 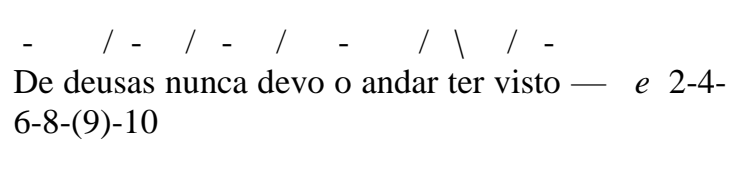 \\
\hline $\begin{array}{l}-\quad /|-\quad| \quad|-\quad| \quad|\quad|-|-| l \mid \\
\text { My mistress when she walks treads on the ground. } \\
f \text { J-J-J-J-J }\end{array}$ & $\begin{array}{l}-\quad-/--\quad / \backslash--1 \\
\text { Minha amante ao andar pisa no chão. } f \text { 3-6-(7)- } \\
10\end{array}$ \\
\hline $\begin{array}{l}-/\|-/|\|-| /-/|-| \mid \\
\text { And yet, by heaven, I think my love as rare } g \text { J-J- } \\
\text { A-J-J } \\
-/|--|-/|-/|-\quad / \mid \\
\text { As any she belied with false compare. } g \text { J-P-J-J-J }\end{array}$ & $\begin{array}{l}-\quad /-\|/-\quad /\| \backslash-1 / /- \\
\text { No entanto, pelos céus, acho-a mais rara } \\
\text { (7)-(9)-10 } \\
-\quad-\quad-\quad / \quad-\quad /---/ \text { - } \\
\text { Do que a mulher que em falso se compara. } \\
10\end{array}$ \\
\hline
\end{tabular}

\section{3 .3}

\section{Anotação feita por EF}

\begin{tabular}{|c|c|}
\hline 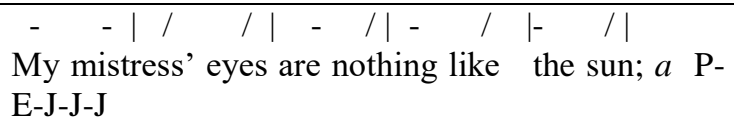 & 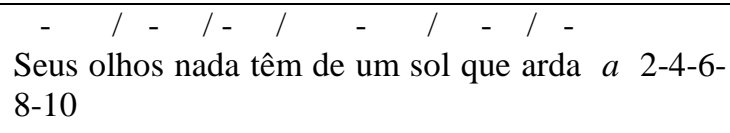 \\
\hline $\begin{array}{l}/-|-/| / /|--| / /|| \\
\text { Coral is far more red than her lips' red; } b \text { T-J-E- } \\
\text { P-E }\end{array}$ & 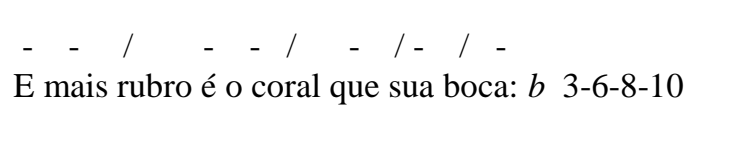 \\
\hline $\begin{array}{l}\quad /|-\quad / \| / /|-c / \mid-1 / \\
\text { If snow be white, why then her breasts are dun; } a \\
\text { J-J-E-J-J }\end{array}$ & $\begin{array}{l}-/-\quad / \quad \| /-/-/- \\
\text { Se a neve é branca, sua tez é parda; } a \text { 2-4-6-8-10 }\end{array}$ \\
\hline
\end{tabular}




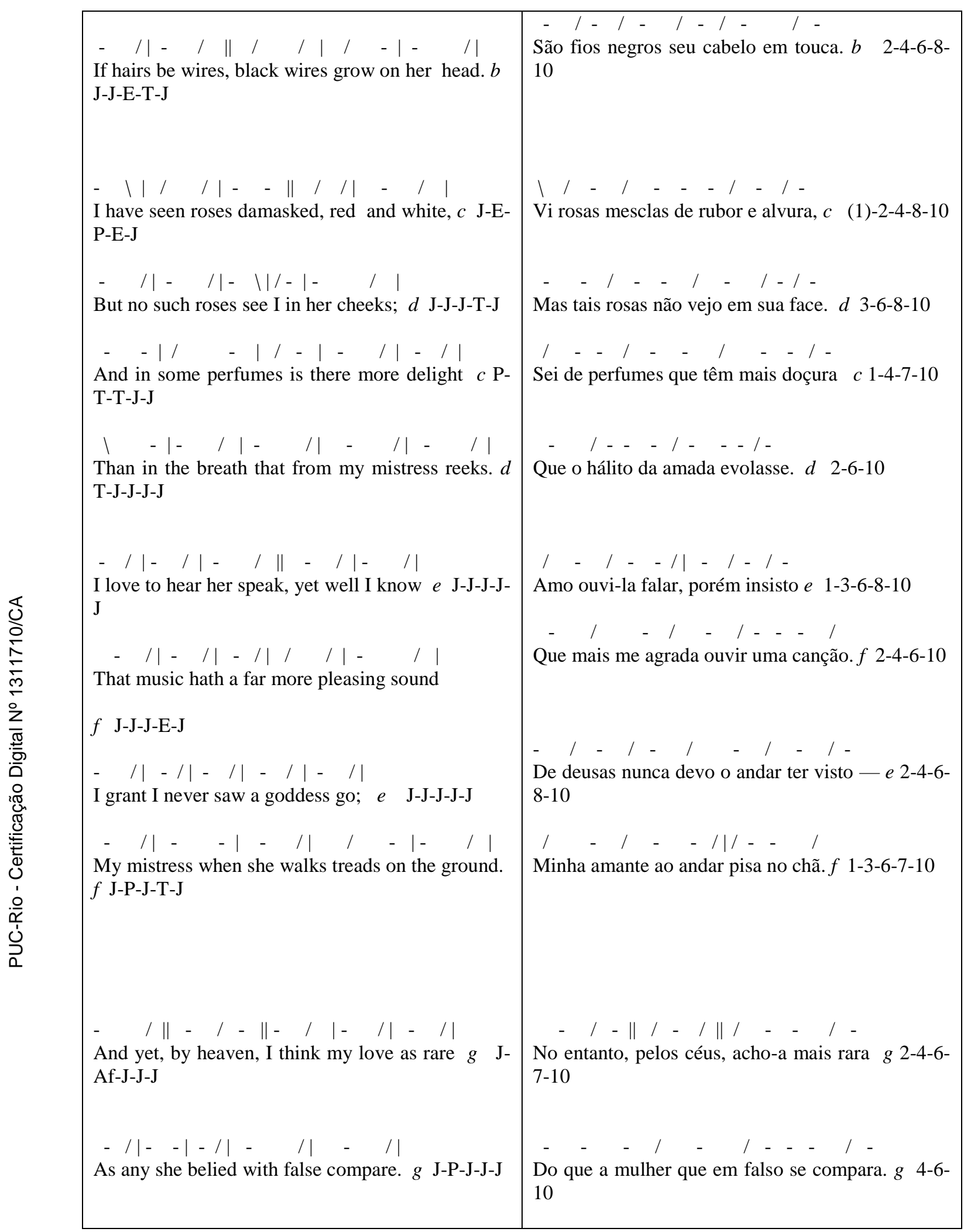

\section{3 .4}

\section{Comparação das anotações e discussão dos resultados}


Notamos que, no original, temos concordância quanto ao tipo de verso utilizado no poema: para os três anotadores, o poema é escrito em pentâmetro jâmbico.

$\mathrm{Na}$ tradução, temos concordância quanto ao número de sílabas em cada verso: para os três anotadores, todos os versos são decassílabos. Tanto $\mathrm{AD}$, quanto EF e eu encontramos heroicos (2-6-10), sáficos (4-8-10) e martelos-agalopados (3-6-10). EF ainda encontrou um outro decassílabo, o provençal (4-7-10): terceiro verso da segunda estrofe.

Quanto ao esquema rimático, também temos concordância: para os três anotadores, a tradução reproduz o mesmo esquema do original: ababcdcdefefgg.

A partir da comparação das anotações, apesar de discordâncias nas escansões, podemos dizer que, ao traduzir os pentâmetros jâmbicos do original, o tradutor utiliza versos que tendem a padrões regulares de acentuação para os decassílabos e, quanto às rimas, o tradutor reproduz o mesmo esquema de rimas do original.

\section{Observação:}

$\mathrm{Na}$ anotação de $\mathrm{EF}$, observamos que no primeiro versodo dístico final ele identificou um pé anfíbraco ( - / -). Como esse pé é muito raro, eu não o coloquei no meu guia F. Dessa forma, EF, para identificá-lo, utilizou a "sigla" Af.

Quanto a esse verso, vejamos, a seguir, sua escansão feita por mim, por AD e por EF:

(a) JC

$-\quad / \|-1||-1|-1|-1 \mid$

And yet, by heaven, I think my love as rare $g$ J-J-J-J-J

Para mim, tal verso é um pentâmetro perfeitamente jâmbico. Aqui, segui a convenção de analisar heaven - tal como even, ever etc. — como monossílabo: hea'en, e'en, e'er.

(b) $\mathrm{AD}$

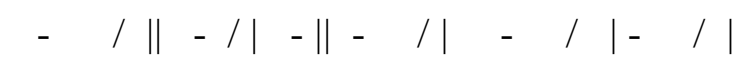

And yet, by heaven, I think my love as rare $g \mathrm{~J}-\mathrm{J}-\mathrm{A}-\mathrm{J}-\mathrm{J}$ 
Para $\mathrm{AD}$, há uma substituição anapéstica no terceiro pé, fenômeno bem comum em poemas escritos em pentâmetros jâmbicos. Mesmo não seguindo a convenção, ao considerar heaven como dissílabo, AD não identificou nenhum pé anfíbraco no verso.

(c) $\mathrm{EF}$

$-1\|-1-\|-1|-1|-1 \mid$

And yet,by heaven,I think my love as rare $g$ J-Af-J-J-J

Assim como $\mathrm{AD}$, EF não seguiu a convenção, e considerou heaven como dissílabo. No entanto, ao separar os pés, EF identificou um anfíbraco no segundo pé, enquanto $\mathrm{AD}$ identificou um anapesto no terceiro pé.

Dessa forma, ao analisar as divergências nas escansões, decidi que, a princípio, não adicionarei o pé anfíbraco ao meu guia, pois, entre os três anotadores, somente um identificou tal pé, que é raríssimo.

\section{4}

\section{Resultados C}

\section{4 .1}

\section{Anotação feita por JC}

\begin{tabular}{|c|c|}
\hline 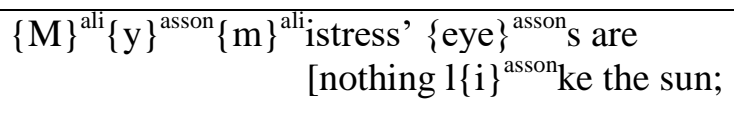 & $\begin{array}{l}\{\mathrm{S}\}^{\text {ali }} \text { eus }\{0\}^{\text {asson }} \text { lhos } n\{a\}^{\text {asson }} \text { da têm de um } \\
\\
{\left[\{s\}^{\text {ali }}\{0\}^{\text {asson }} 1 \text { que }\{a\}^{\text {asson }} \text { rda }\right.}\end{array}$ \\
\hline $\begin{array}{r}\operatorname{Co}\{r\}^{\text {ali }} \text { al is fa }\{r\}^{\text {ali }} \operatorname{mo}\{r\}^{\text {ali }} \text { e }\{r\}^{\text {ali }} \text { ed than } \\
{\left[\text { he }\{r\}^{\text {ali }} \text { lips }\{r\}^{\text {ali }} \text { ed; }\right.}\end{array}$ & $\begin{array}{l}\text { E mais rubro é o c }\{0\}\}^{\text {asson }} \text { ral que sua } \\
\qquad\left[b\{o\}{ }^{\text {asson }} \mathrm{ca} \text { : }\right.\end{array}$ \\
\hline $\begin{array}{l}\text { If snow be }\{\text { whi }\}^{\text {repd }} \text { te, }\{\text { why }\}^{\text {repd }} \text { then he }\{r\}^{\text {ali }} \\
\qquad b\{r\}^{\text {ali }} \text { easts a }\{r\}^{\text {ali }} \text { e dun; }\end{array}$ & 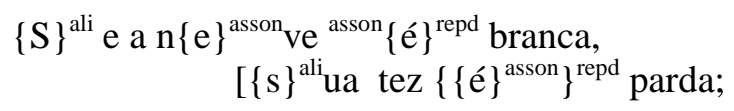 \\
\hline $\begin{array}{l}\text { If }\{\mathrm{h}\}^{\text {ali }}\{\text { ai }\}^{\text {asson }}\{\mathrm{r}\}^{\text {ali }} \text { s be }\left\{\text { wi }\{r\}^{\text {ali }} \text { es }\right\}^{\text {repd }}, \\
{\left[\text { black }\left\{w i\{r\}^{\text {ali }} \text { es }\right\}^{\text {repd }} \text { g }\{r\}^{\text {ali }} \text { ow on }\right.}\end{array}$ & $\begin{array}{r}\text { São fios } n\{e\}^{\text {asson }} \text { gros } s\{e\}^{\text {asson }} u \text { cab }\{e\}^{\text {asson }} \text { lo } \\
{[e m \text { touca. }}\end{array}$ \\
\hline
\end{tabular}




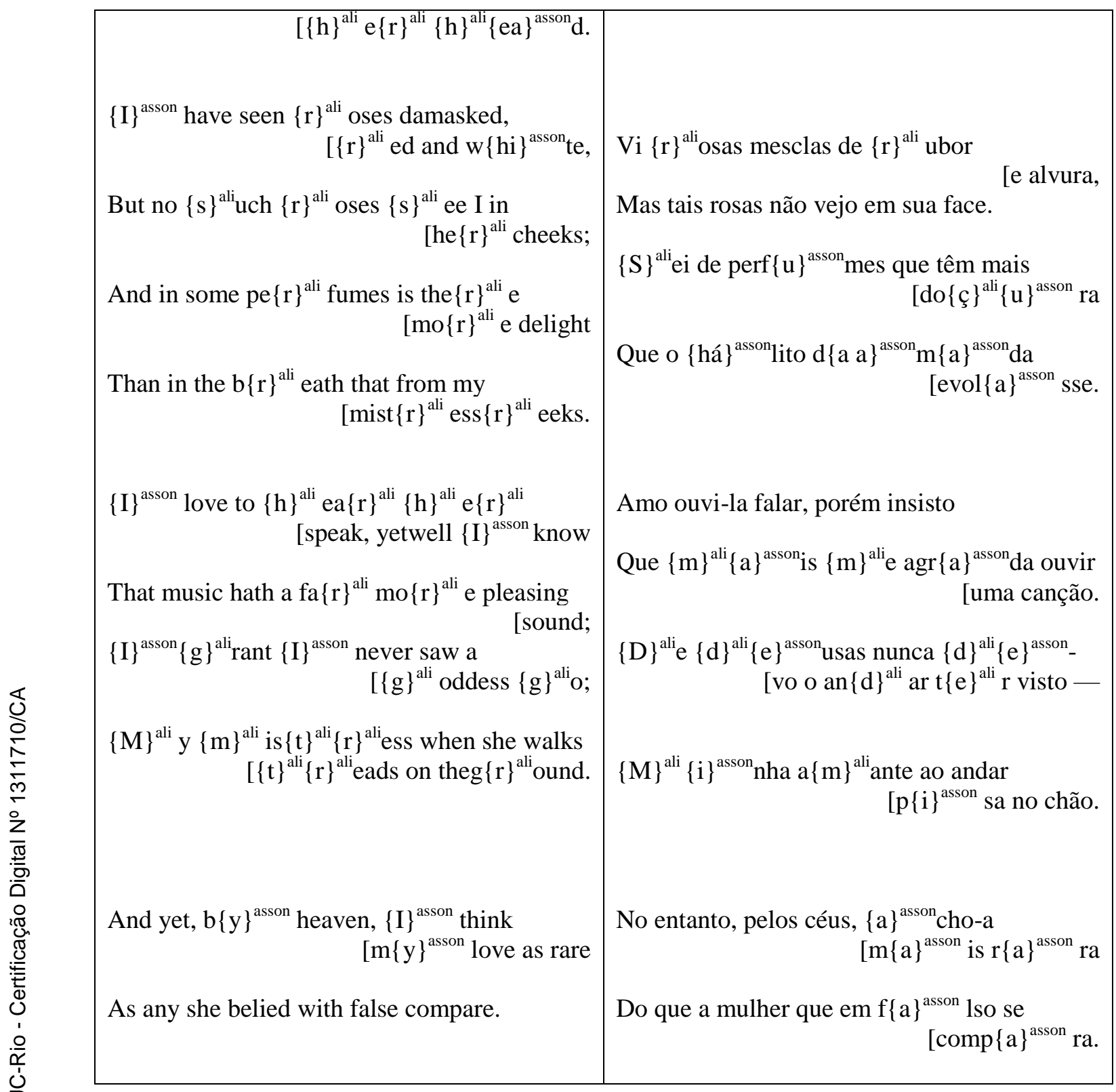

\section{4 .2}

\section{Anotação feita por AD}

$\begin{aligned}\{\mathrm{M}\}^{\text {ali }}\{\mathrm{y}\}^{\text {asson }}\{\mathrm{m}\}^{\text {ali }} & \text { istress' }\{\text { eye }\}^{\text {asson }} \text { are } \\ & {\left[\text { nothing } 1\{i\}^{\text {asson }} \text { ke the sun; }\right.}\end{aligned}$

Coral is far more ${ }^{\text {asson }}\{\text { red }\}^{\text {repd }}$ than $\{\text { her }\}^{\text {repd }}$ $\left[\right.$ lips ${ }^{\text {asson }}\{\text { red }\}^{\text {repd }}$

$\left\{\right.$ If ${ }^{\text {repd }}$ snow be $\{w\}^{\text {ali }} h\{i\}^{\text {asson }}$ te,

$\left[\{w\}^{\text {ali }} \mathrm{h}\{\mathrm{y}\}^{\text {asson }}\right.$ then $\left\{\right.$ her ${ }^{\text {repd }}$ br $\{\text { ea }\}^{\text {asson }}$ sts are

[dun;

$\{\text { If }\}^{\text {repd }} \mathrm{h}\{\text { ai }\}^{\text {asson }}$ rs be $\left\{\{\mathrm{w}\}^{\text {ali }}\{\mathrm{i}\}^{\text {asson }} \text { res }\right\}^{\text {repd }}$,

$\left[\right.$ black $\left\{\{w\}^{\text {ali }}\{i\}^{\text {asson }} \text { res }\right\}^{\text {repd }}$ grow on $\{\text { her }\}^{\text {repd }}$
$\{\mathrm{S}\}^{\text {ali }}$ eus $\{\mathrm{o}\}^{\text {asson }}$ hos $\mathrm{n}\{\mathrm{a}\}^{\text {asson }}$ da têm de um $\left[\{s\}^{\text {ali }}\{0\}\right\}^{\text {asson }} 1$ que $\{a\}^{\text {asson }}$ rda

E mais rubro $\{e ́\}^{\text {asson }}$ o coral que $\{s\}^{\text {ali }}$ ua boca:

$\{S\}^{\text {ali }}$ e a $n\{e\}^{\text {asson }}$ ve $\{e ́\}^{\text {asson }}$ branca, $\{s\}^{\text {ali }}$ ua tez é parda;

$\{S\}\}^{\text {ali }}$ ão fios $n\{e\}^{\text {asson }}$ gros $\{s\}^{\text {ali }}$ eu cab $\{e\}^{\text {asson }}$ lo [em touca. 


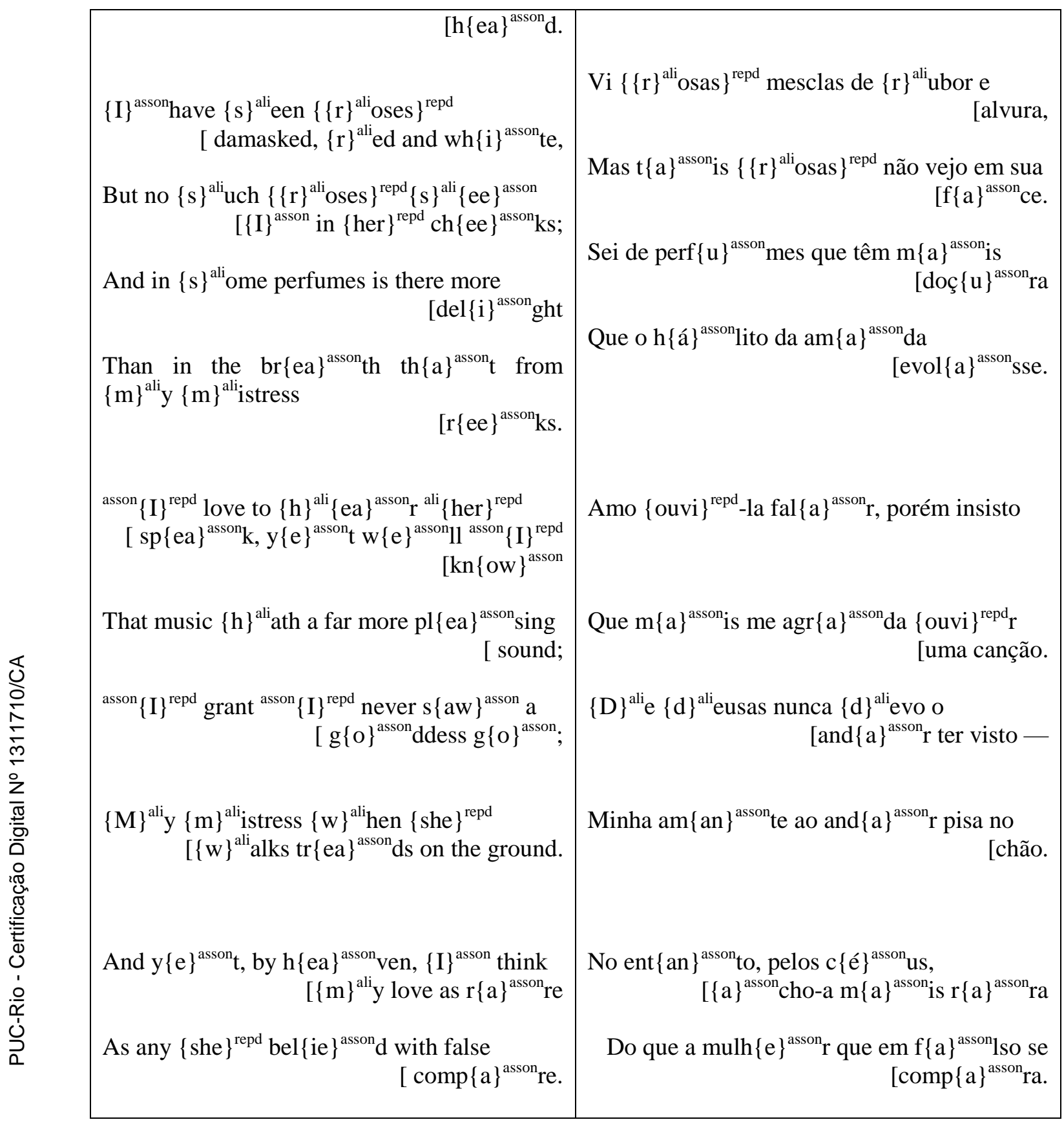

\section{4 .3}

\section{Anotação feita por EF}

\begin{tabular}{|c|c|}
\hline 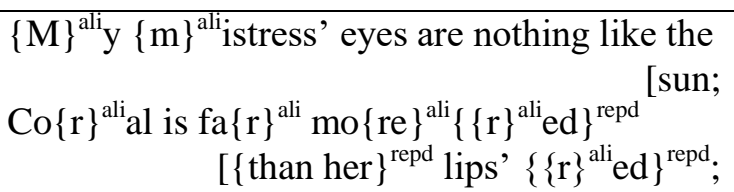 & $\begin{array}{l}\text { Seus olhos } n\{a\}^{\text {asson }} \text { da têm de um sol que } \\
\qquad\{a\}^{\text {asson }} \text { rda } \\
\text { E mais ru }\{b\}^{\text {ali }} \text { ro é o coral que sua }\{b\}^{\text {ali }} \text { oca: }\end{array}$ \\
\hline
\end{tabular}




\begin{tabular}{|c|c|}
\hline $\begin{array}{l}\{\text { If }\}^{\text {repd }} \text { snow be }\left\{\{\mathrm{w}\}^{\text {ali }} h\{\mathrm{i}\}^{\text {asson }} \text { te }^{\text {repd }},\right. \\
{\left[\{\mathrm{w}\}^{\text {ali }} \mathrm{h}\{\mathrm{y}\}^{\text {asson }}\{\text { then her }\}^{\text {redp }} \text { breasts are dun; }\right.} \\
\{\text { If }\}^{\text {repd }} \text { hairs be }\left\{\{\mathrm{w}\}^{\text {ali }}\{\mathrm{i}\}^{\text {asson }} \text { res }\right\}^{\text {repd }} \text {, black } \\
{\left[\left\{\{\mathrm{w}\}^{\text {ali }}\{\mathrm{i}\}^{\text {asson }} \text { res }\right\}^{\text {repd }} \text { grow on }\left\{\{\mathrm{h}\}^{\text {ali er }}\right\}^{\text {repd }}\right.} \\
{\left[\{\mathrm{h}\}^{\text {ali ead. }}\right.}\end{array}$ & São $\left.\{f\}^{\text {ali }}{ }^{\text {ios negros seu ca }\{b}\right\}^{\text {ali }}$ elo em touca. \\
\hline 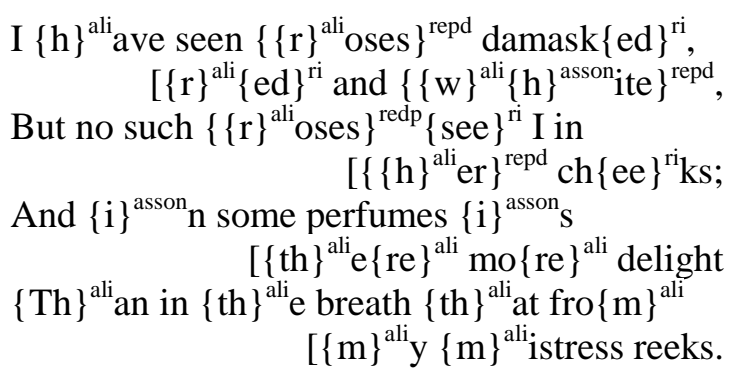 & 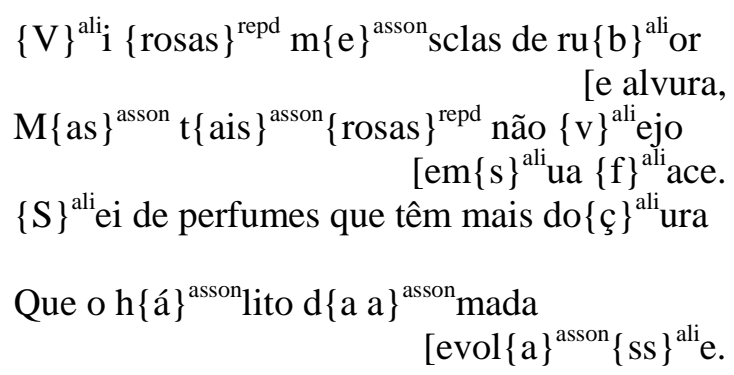 \\
\hline 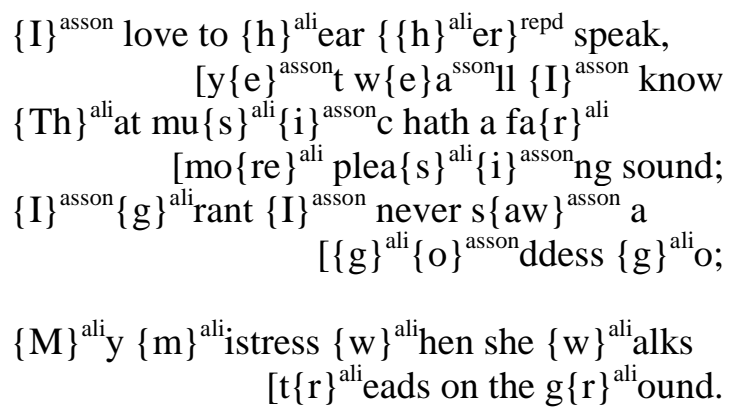 & 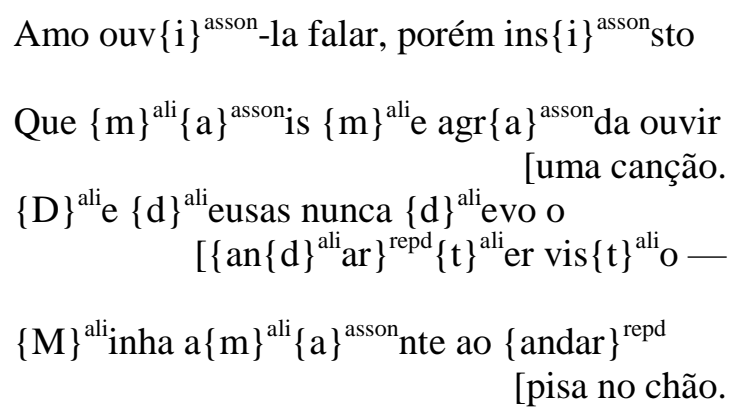 \\
\hline $\begin{array}{l}\text { And } y\{e\}^{\text {asson }} \text { t, by } h\{\mathrm{ea}\}{ }^{\text {asson }} \text { ven, I think } \\
\qquad\left[\{\mathrm{m}\}^{\text {ali }} \text { y love as ra }\{\mathrm{re}\}^{\text {ali }}\right. \\
\text { As any she belied with false compa }\{\mathrm{re}\}^{\text {ali }} \text {. }\end{array}$ & 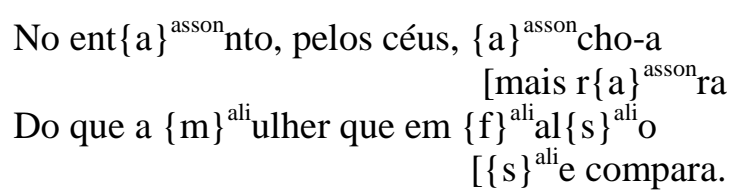 \\
\hline
\end{tabular}

\section{4 .4}

\section{Comparação das anotações e discussão dos resultados}

Comparando as três anotações, foi possível observar que houve recursos que um anotador anotou e outro não, tanto no original quanto na tradução. Dois exemplos disso são a aliteração em /ð/ (Than, the, that), no quarto verso da segunda estrofe do original, anotada somente por EF; e a aliteração em /s/ (falso, se), no último verso do dístico da tradução, também anotada somente por EF. Mesmo com discordâncias como essas, podemos dizer que os recursos sonoros, nos poemas em inglês e em português, não têm função estruturante, diferentemente das rimas e do metro. 


\section{5}

\section{Resultados D}

\subsection{1}

\section{Anotação feita por JC}

My mistress' eyes are nothing like the sun; $\{\text { Coral is far more red than her lips' red }\}^{\text {asem1}}$; If snow be white, $\{\text { why then }\}^{\text {omil }}$ her breasts [are dun;

If hairs be wires, black wires \{ grow on her [head. $]^{\text {asem2 }}$

I have seen roses damasked, red and white, But no such roses $\{\text { see I }\}^{\text {asem3 }}$ in her cheeks;

And in some perfumes is there more $\left[\{\text { delight }\}^{\text {asem } 4}\right.$

Than in the breath that from my mistress [reeks.

I love to hear her speak, yet $\{\text { well }\}^{\text {omi2 }}$ I know That music $\left\{\right.$ hath ${ }^{\text {omi3 }}$ a $\{\text { far }\}^{\text {omi4 }}$ more $\{\text { I grant }\}^{\text {omi5 }}$ I never saw a goddess go; [pleasing sound; My mistress when she walks \{treads ${ }^{\text {asem5 }}$ on [the ground.

And yet, by heaven, I think my love as rare As \{ any she belied with false $[\text { compare }\}^{\text {asem6 }}$.
O seu olhar não é o de um sol \{puro ${ }^{\text {acrl}}$; $\{\text { Nenhum coral os lábios lhe acendeu }\}^{\text {asem1 }}$; Se a neve é branca, os seios tem escuros;

Se são fio os cabelos, negro \{é o seu $\}^{\text {asem2 }}$.

Já vi rosas damasco, branco-e-rosa, Porém nenhuma em sua face $\{\text { esplende }\}^{\text {asem3 }}$ E há muita essência $\{\text { bem }\}^{\text {acr2 }}$ mais $\left[\{\text { perfumosa }\}^{\text {asem } 4}\right.$

Que os hálitos que dela se desprendem.

Adoro a sua voz, ainda quando

Saiba mais doce o som de uma canção;

Nunca vi uma deusa caminhando; Já minha amada, andando \{esflora $\}^{\text {asem5 }} \mathrm{o}$ [chão:

Mas, pelos céus, eu creio que é tão rara

Quanto \{as que em falsa imagem se [comparam $\}^{\text {asem6 }}$. 
Ao todo anotei 13ocorrências de categorias. Separando e contabilizando as categorias, temos: 2 acréscimos, 6 alterações semânticas, e 5 omissões, como ilustra a tabela A:

TABELA A:

\begin{tabular}{|c|c|}
\hline Categoria & $\begin{array}{c}\mathbf{N}^{\mathbf{o}} \text { de } \\
\text { ocorrências }\end{array}$ \\
\hline Acréscimo & 2 \\
\hline Alteração semântica & 6 \\
\hline Omissão & 5 \\
\hline
\end{tabular}

\section{5 .2}

\section{Anotação feita por AS}

$\{\text { My mistress' }\}^{\text {omil }}$ eyes are nothing like the sun;

Coral is far more red than her lips' red;

If snow be white, why then her breasts are

If hairs be wires, black $\left\{\right.$ wires ${ }^{\text {omi2 }}$ grow on her head.

I have seen roses damasked, red and white, But no such roses $\{\text { see I }\}^{\text {asem1 }}$ in her cheeks; And in some perfumes is there more delight Than in the breath that from my mistress $\{\text { reeks }\}^{\text {asem2 }}$

I love to hear her speak, yet well I know That music hath a far more pleasing sound; $\{\text { I grant }\}^{\text {omi3 }}$ I never saw a goddess go; My mistress when she walks $\{\text { treads }\}^{\text {asem3 }}$ on the [ground.

And yet, by heaven, I think \{my
O seu olhar não é o de um sol $\{\text { puro }\}^{\text {acr. }}$; Nenhum coral os lábios lhe acendeu; Se a neve é branca, os seios tem escuros;

Se são fio os cabelos, negro é o seu.

Já vi rosas damasco, branco-e-rosa, Porém nenhuma em sua face $\{\text { esplende }\}^{\text {asem1 }}$ E há muita essência bem mais perfumosa Que os hálitos que dela se $\{\text { desprendem }\}^{\text {asem2 }}$.

Adoro a sua voz, ainda quando

Saiba mais doce o som de uma canção;

Nunca vi uma deusa caminhando;

Já minha amada, andando $\{\text { esflora }\}^{\text {asem3 }}$ o chão:

Mas, pelos céus, eu creio que é tão rara 


\begin{tabular}{|c|c|}
\hline $\begin{array}{l}\text { love }{ }^{\mathrm{omi} 4} \text { as rare } \\
\text { As any she belied with false compare. }\end{array}$ & Quanto as que em falsa imagem se comparam. \\
\end{tabular}

Ao todo, AS anotou 8 ocorrências de categorias, sendo 1 acréscimo, 4 omissões e 3 alterações semânticas, como ilustra a tabela B:

TABELA B:

\begin{tabular}{|c|c|}
\hline Categoria & $\begin{array}{c}\mathbf{N}^{\mathbf{0}} \text { de } \\
\text { ocorrências }\end{array}$ \\
\hline Acréscimo & 1 \\
\hline Alteração semântica & 3 \\
\hline Omissão & 4 \\
\hline
\end{tabular}

\section{5 .3}

\section{Anotação feita por MM}

$\{\text { My mistress' }\}^{\text {omi1 }}$ eyes are nothing like the Coral $\{\text { is far more red than her lips' red }\}^{\text {asem1; }}$ If snow be white, why then her breasts are [dun;

If hairs be wires, black wires grow on her [head.

I have seen roses damasked, red and $\{\text { white }\}^{\text {asem2 }}$,

But no such roses see I in her cheeks;

And in some perfumes is there more delight

Than in the breath that from my mistress $\left[\{\text { reeks }\}^{\text {asem } 3}\right.$.

I love to hear her speak, yet well I know That music hath a far more pleasing sound; I grant I never saw a goddess go;

My mistress when she walks treads on the
O seu olhar não é o de um sol $\{\text { puro }\}^{\text {acr1; }}$; Nenhum coral \{os lábios lhe acendeu ${ }^{\text {asem1; }}$ Se a neve é branca, os seios tem escuros; Se são fio os cabelos, negro é o seu.

Já vi rosas damasco, branco-e- $\left\{\right.$ rosa ${ }^{\text {asem2 }}$, Porém nenhuma em sua face $\left\{\right.$ esplende ${ }^{\text {acr2 }}$ E há muita essência bem mais perfumosa Que os hálitos que dela \{se desprendem $\}$ asem3

Adoro a sua voz, ainda quando

Saiba mais doce o som de uma canção; Nunca vi uma deusa caminhando;

Já minha amada, andando esflora o chão: 


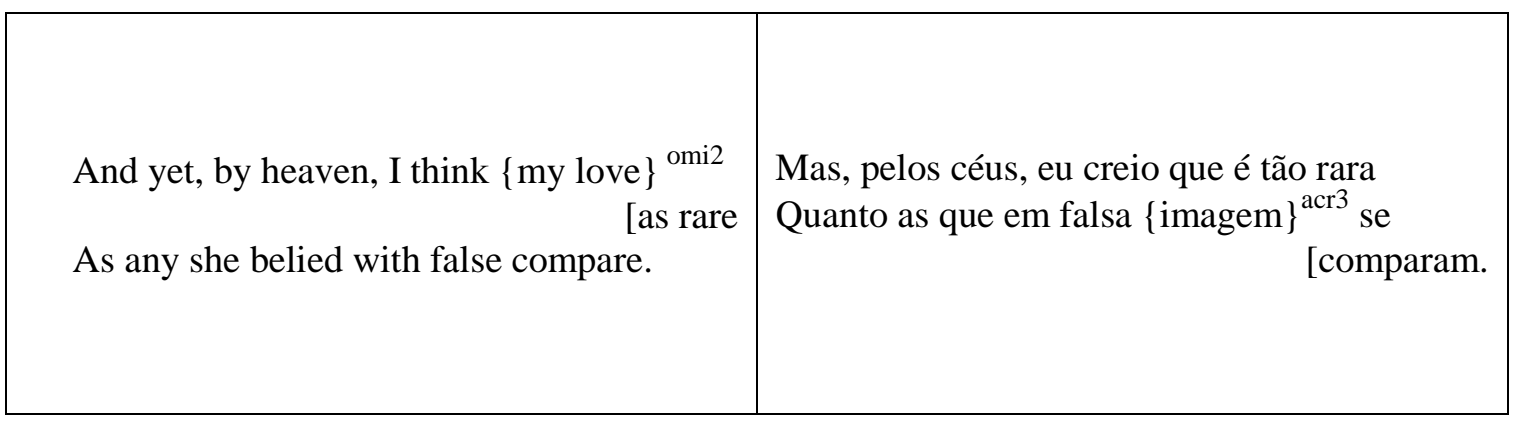

Ao todo, MM anotou 8 ocorrências de categorias, sendo 3 acréscimos, 2 omissões e 3 alterações semânticas, como ilustra a tabela C:

TABELA C:

\begin{tabular}{|c|c|}
\hline Categoria & $\begin{array}{c}\mathrm{N}^{\mathbf{0}} \text { de } \\
\text { ocorrências }\end{array}$ \\
\hline Acréscimo & 3 \\
\hline Alteração semântica & 3 \\
\hline Omissão & 2 \\
\hline
\end{tabular}

\section{5 .4}

Comparação das anotações

TABELA D:

\begin{tabular}{|c|c|}
\hline Anotadores & Número de ocorrências anotadas \\
\hline JC & 13 \\
\hline AS & 8 \\
\hline MM & 8 \\
\hline
\end{tabular}

Veremos a seguir, neste subcapítulo, as discordâncias que aconteceram nessas ocorrências anotadas.

TABELA E:

\begin{tabular}{|c|c|}
\hline Anotadores & $\begin{array}{c}\text { Total de ALTERAÇÕES } \\
\text { SEMÂNTICAS }\end{array}$ \\
\hline JC & 6 \\
\hline
\end{tabular}




\begin{tabular}{|c|c|}
\hline AS & 3 \\
\hline MM & 3 \\
\hline
\end{tabular}

Quanto às alterações semânticas, houve oito discordâncias:

Uma alteração semântica foi anotada somente por MM e por mim:

Primeira estrofe, segundo verso: de "Coral is far more red than her lips' red" $(O$ coral é bem mais rubro que seus lábios) para "Nenhum coral os lábios lhe acendeu".

Duas alterações semânticas foram anotadas somente por AS e por mim:

Segunda estrofe, segundo verso: de "see I" (vejo) para " esplende". Nesse caso, MM anotou "esplende" como acréscimo.

Terceira estrofe, quarto verso: "treads" (pisa com força) para "esflora".

Uma alteração semântica foi anotada somente por AS e MM:

Segunda estrofe, quarto verso: de "reeks" (cheiram mal) para "se desprendem".

Três alterações semânticas foram anotadas somente por mim:

Primeira estrofe, quarto verso: "grow on her head" (crescem em sua cabeça) para "é o seu".

Segunda estrofe, terceiro verso: de "delight" (deleite) para "perfumosa".

Dístico final, segundo verso: de "any she belied with false compare" (as que em falsa imagem [ela] se compara) para "as que em falsa imagem se comparam". Nesse caso, MM anotou “imagem” como acréscimo.

Uma alteração semântica foi anotada somente por MM:

Segunda estrofe, primeiro verso: de "white" (branco) para "rosa".

TABELA F:

\begin{tabular}{|c|c|}
\hline Anotadores & Total de OMISSÕES \\
\hline JC & 5 \\
\hline AS & 4 \\
\hline MM & 2 \\
\hline
\end{tabular}


Quanto às omissões, houve oito discordâncias:

Duas omissões foram anotadassomentepor AS e MM:

Primeira estrofe, primeiro verso: "My mistress" (Minha amada).

Dístico final, primeiro verso: "my love" (Minha amada).

Uma omissão foi anotada somente por AS e por mim:

Terceira estrofe, terceiro verso: "I grant" (Eu reconheço que)

Quatro omissões foram anotadas somente por mim:

Primeira estrofe, terceiro verso: "why then" (ora então).

Terceira estrofe, primeiro verso: “well” (bem).

Terceira estrofe, segundo verso: "hath" (tem) e "far" (bem).

Uma omissão foi anotada somente por AS:

Primeira estrofe, quarto verso: o segundo "wires" (fios)

\section{TABELA G:}

\begin{tabular}{|c|c|}
\hline Anotadores & Total de ACRÉSCIMOS \\
\hline JC & 2 \\
\hline AS & 1 \\
\hline MM & 3 \\
\hline
\end{tabular}

Quanto aos acréscimos, houve trêsdiscordâncias:

Um acréscimo foi anotado somente por mim:

Segunda estrofe, terceiro verso: "bem".

Dois acréscimos foram anotados somente por MM:

Segunda estrofe, segundo verso: "esplende".

Dístico final, segundo verso: "imagem". 
TABELA H:

\begin{tabular}{|c|c|}
\hline Total de concordâncias & 1 \\
\hline Total de discordâncias & 19 \\
\hline Categorias que levaram a mais & ACRÉSCIMO \\
concordâncias & e \\
\hline Categorias que levaram a mais & OLTSSSÃO \\
discordâncias & TODAS FORAM ENCONTRADAS \\
\hline Categorias que não foram encontradas & OLATICA \\
\hline
\end{tabular}

Em relação às 19 discordâncias, 8foram quanto a alterações semânticas, 8 em relação às omissões, e 3referentes aos acréscimos.

Quanto às categorias que levaram a mais concordâncias, observamos que ACRÉSCIMO foi a categoria que apresentou a única convergênciaentre os três anotadores:acréscimo de "puro", no primeiro verso da primeira estrofe.

Já quanto às categorias que levaram a mais discordâncias, notamos que ALTERAÇÃO SEMÂNTICA e OMISSÃOnão apresentaram nenhuma convergênciaentre os três anotadores. Nessa análise observamos, também, que todas as três categorias do guia SL3 foram encontradas pelos três anotadores.

\section{5 .5}

\section{Discussão dos resultados}

De acordo com a Tabela $\mathrm{H}$, a categoria que levou a mais concordâncias foiACRÉSCIMO. Tal categoria foi a responsável por apenas uma convergência entre os três anotadores; a única concordância entre todos os três estudiosos. Segundo essa mesma tabela, as categorias que levaram a mais discordâncias foram ALTERAÇÃO SEMÂNTICA e OMISSÃO. Tais categorias levaram somente a discordâncias entre os três anotadores. Podemos dizer que, de um modo geral, é compreensível haver mais divergências quanto à categoria ALTERAÇÃO SEMÂNTICA, pois suas explicações não apresentam uma contraparte formal, o que dificultaria sua identificação. Já quanto às categorias ACRÉSCIMO e OMISSÃO, que têm um complemento formal - 
acréscimo de palavras e omissão de palavras, respectivamente - espera-se mais convergências, pela maior facilidade em detectá-las.

Ainda com relação à categoria ALTERAÇÃO SEMÂNTICA, segundo os resultados obtidos pela comparação da minha anotação com a de EF, observamos que, de acordo os resultados A2, tal categoria levou a mais concordâncias. Uma outra explicação pela qual, agora,essa categoriatenha levado a mais divergências é, talvez, uma má reformulação de suas explicações.No cômputo geral, nenhuma dessas categorias possibilitou muitas concordâncias, pelo contrário, houve muita discordância, referentes a todas as três categorias, entre os três anotadores.A seguir, discutiremos as discordâncias.

Quanto às alterações semânticas, observamos oito divergências. Há uma que somente eu e MM anotamos: "Coral is far more red than her lips' red" ( $O$ coral é bem mais rubro que seus lábios) para "Nenhum coral os lábios lhe acendeu", no segundo verso da primeira estrofe. Nesse caso, a tradução apresenta o sentido de que nenhum coral acendeu os lábios da amada e, no original, há apenas uma comparação entre o rubro do coral e aquele dos lábios da amada. Dessa forma, acredito que há alteração de elementos semânticos no verso.

Ocorreram também duas alterações anotadas somente por mim e AS, a primeira é a que acontece entre“see I" (vejo) e “ esplende", no segundo verso da segunda estrofe.Na tradução do verso "But no such roses $\{$ see $\mathrm{I}\}{ }^{\text {asem }}$ in her cheeks" para "Porém nenhuma em sua face $\{\text { esplende }\}^{\text {asem }}$ ", todos os elementos semânticos do original são mantidos, exceto aquele presente em "see I", que é alterado para "esplende", verbo que creio não ser nem sinônimo, hipônimo ou hiperônimo de "vejo". A segunda ocorreu no quarto verso da terceira estrofe: "treads" (pisa com força) para "esflora". Aqui, a tradução altera o elemento semântico de "treads" ao utilizar o verbo "esflora", que acredito não ser nem sinônimo, hipônimo ou hiperônimo de "pisa com força".

Há uma alteração semântica anotada somente por AS e MM: de "reeks" (cheiram mal) para "se desprendem", no quarto verso da segunda estrofe. Acredito que "reeks" é traduzido pelo hiperônimo "se desprendem", não configurando, assim, uma alteração semântica. Outrastrês alterações semânticas foram anotadas somente por mim: de "grow on her head" (crescem em sua cabeça) para "é o seu", no quarto verso da primeira estrofe; de "delight" (deleite) para "perfumosa", no terceiro verso da segunda estrofe; e de "any she belied with false compare" (as que em falsa imagem [ela] se compara) para "as que em falsa imagem se comparam", no segundo verso do dístico 
final. Quanto ao primeiro - "If hairs be wires, black wires $\left\{\right.$ grow on her head ${ }^{\text {asem," }}$ para "Se são fio os cabelos, negro \{é o seu $\}^{\text {asem " }}$ - em inglês, temos a ideia de que fios negros crescem na cabeça da amada, expressa por verbo (grow) + preposições (on) + pronome (her) + substantivo (head). E, em português, encontramos a noção de que o fio (de cabelo) dela é negro: uma ideia de crescimento foi traduzida por uma noção de ser, estar, expressa por verbo (é) + artigo (o) + pronome (seu). Além disso, as explicaçõesda categoria em questão não consideram como alterações semânticas aquelas que ocorrem entre preposições, pronomes e artigos isolados, da tradução e do original. Nesse caso, temos tais classes gramaticais em conjunto com substantivos e verbos. A partir disso tudo, podemos dizer que ocorreu alteração semântica na tradução em questão. Em relação ao segundo, "delight" foi traduzido por um adjetivo que creio não ser nem seu sinônimo, hipônimo ou hiperônimo. Quanto ao terceiro, o verso original trata das mulheres que em falsa imagem a amada do eu-lírico se compara, já a tradução trata das mulheres que em falsa imagem se comparam entre si.Há ainda uma alteração semântica que somente MM anotou: de "white" (branco) para "rosa", no primeiro verso da segunda estrofe. Creio que, nesse caso, a tradução inverte os termos "red and white" em "branco-e-rosa", mantendo, assim, os elementos semânticos desse trecho do original.O par de adjetivos "red and white" compara o rubor das rosas com o rubor no rosto da amada (que, na verdade, não há). Dessa forma, creio que possamos dizer que "branco-e-rosa" funciona como um sinônimo de "red and white" aqui.

Quanto às omissões, observamos oito discordâncias. Duas foram anotadas somente por AS e MM: "My mistress" (Minha amada), no primeiro verso da primeira estrofe; e "my love" (Minha amada), no primeiro versodo dístico final. De fato, nos trechos correspondentes da tradução, não há os termos "minha amada", "meu amor", ou quaisquer outras combinações de pronomes possessivos e de substantivos que possam ser consideradas sinônimos de "My mistress" e/ou de "my love". No entanto, em "O seu olhar não é o de um sol puro" como tradução de "My mistress' eyes are nothing like the sun", a amada do eu-lírico está no pronome "seu"; e em "Mas, pelos céus, eu creio que é tão rara", como tradução de "And yet, by heaven, I think my love as rare", essa mesma amada está na elipse do pronome "ela", que ocorre entre "que" e "é". A partir disso, notei que precisaria reformular as explicações da categoria OMISSÃO. Há uma omissão anotada somente por AS e por mim: "I grant" (Eu reconheço que), no terceiro verso da terceira estrofe.Em "Nunca vi uma deusa caminhando", como tradução de "\{I 
grant ${ }^{\text {omi }}$ I never saw a goddess go", notamos omissão dos elementos semânticos presentes na oração "I grant".

Observamos quatro omissões que somente eu anotei: "If snow be white, why then $\}^{\text {omi }}$ her breasts are dun", no terceiro verso da primeira estrofe; e "I love to hear her speak, yet $\{\text { well }\}^{\text {omi }}$ I know/ That music $\{\text { hath }\}^{\text {omi }}$ a $\{\text { far }\}^{\text {omi }}$ more pleasing sound", no primeiro e segundo verso da terceira estrofe.Na primeira estrofe, temos omissão dos elementos semânticos presentes em "why then" (interjeição + advérbio). E, na terceira estrofe, encontramos omissão dos elementos semânticos presentes em "well" (advérbio); "hath" (verbo) ; e "far" (advérbio). Levando em conta as explicaçõesda categoria OMISSÃO, podemos dizer que elas se aplicam a quase todos esses casos. No caso da omissão de "why then", como esta é uma combinação de interjeição + advérbio, minha anotação me faz pensar que, talvez, as explicações da categoria em questão precisem de reformulações, para incluir a questão da interjeição. Notamos ainda uma omissão anotada somente por AS: o segundo "wires" (fios), no quarto verso da primeira estrofe.Realmente, em "Se são fio os cabelos, negro é o seu." , como tradução de "If hairs be wires, black wires grow on her head." , não há o segundo termo "fio", ou qualquer outro que possa ser considerado de "wires". Porém, o elemento semântico presente em "wires" (fio) está na elipse que ocorre entre a vírgula e "negro". Dessa formapercebi, novamente, que precisariarefinar as explicações da categoria OMISSÃO.

Quanto aos acréscimos, observamos três discordâncias. Há um anotado somente por mim: "bem", no terceiro verso da segunda estrofe. Na tradução de "And in some perfumes is there more delight" para "E há muita essência $\{\text { bem }\}^{\text {acr }}$ mais perfumosa", notamos acréscimo do elementos semântico presente no advérbio "bem". Assim, de acordo com as explicações da categoria em questão, podemos dizer que temos acréscimo nesse verso. Observamos, ainda, dois acréscimos anotados somente por MM: "esplende", no segundo verso da segunda estrofe; e "imagem", no segundo verso do dístico final. Na tradução do verso "But no such roses $\{\text { see } \mathrm{I}\}^{\text {asem }}$ in her cheeks" para "Porém nenhuma em sua face \{esplende\} ${ }^{\text {asem }}$ ", todos os elementos semânticos do original são mantidos, exceto aquele presente em "see I", que é alterado para "esplende". E, na tradução do verso " $\{\text { any she belied with false compare }\}^{\text {asem" (as que }}$ em falsa imagem [ela] se compara) para " \{as que em falsa imagem se comparam\} ${ }^{\text {asem", }}$ não considero que há acréscimo de "imagem" aqui,pois creio que "falsa imagem" recupera os sentidos de "belied" (o verbo "belie" significa "mostrar-se falso (a)") e 
"false" (falso(a)).Nesses casos, não temos acréscimos, e sim alteração de elementos semânticos, como já foi discutido em parágrafos anteriores neste subcapítulo.

\section{6}

\section{Resultados E}

\subsection{1}

\section{Anotação feita por JC}

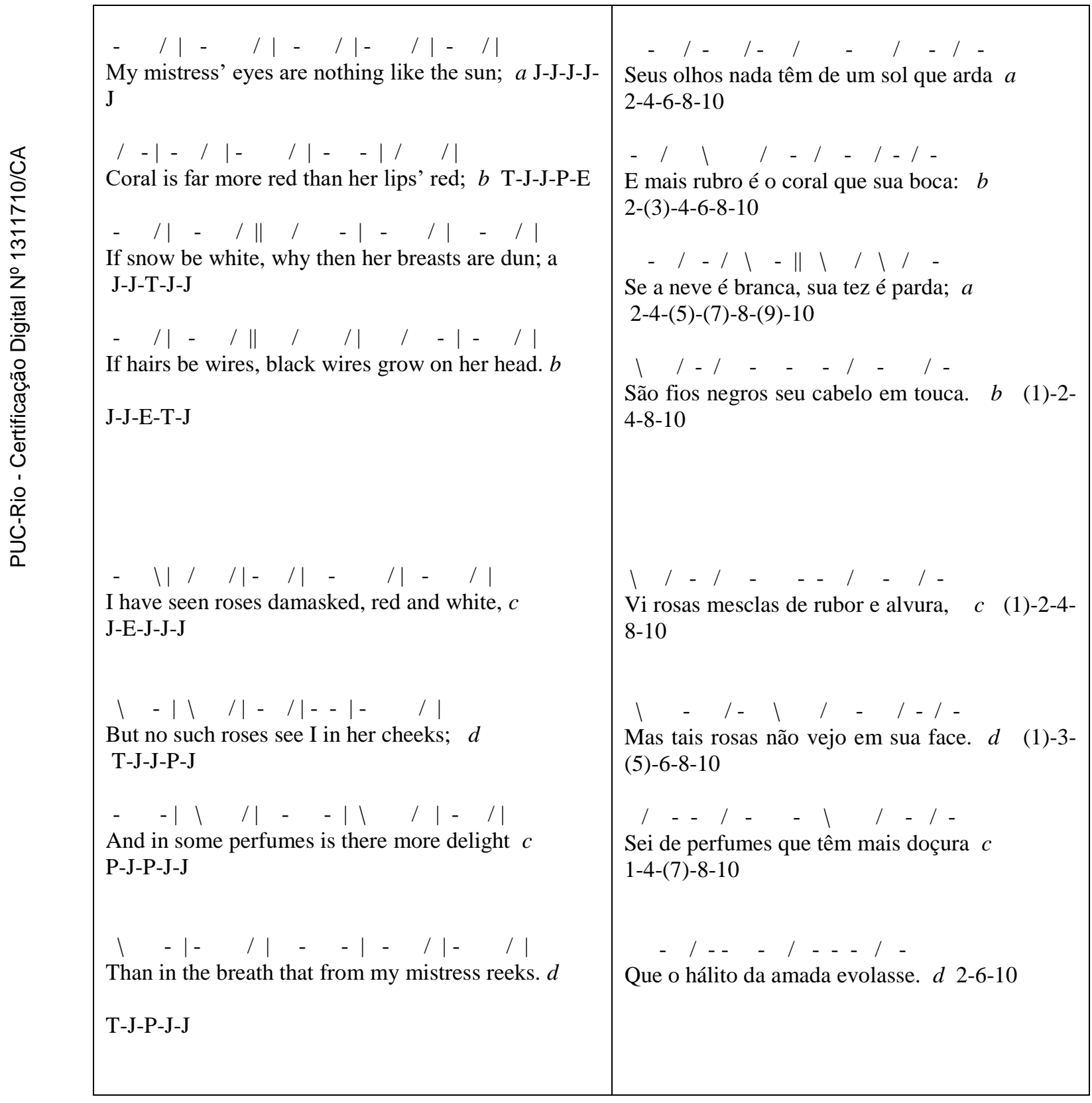




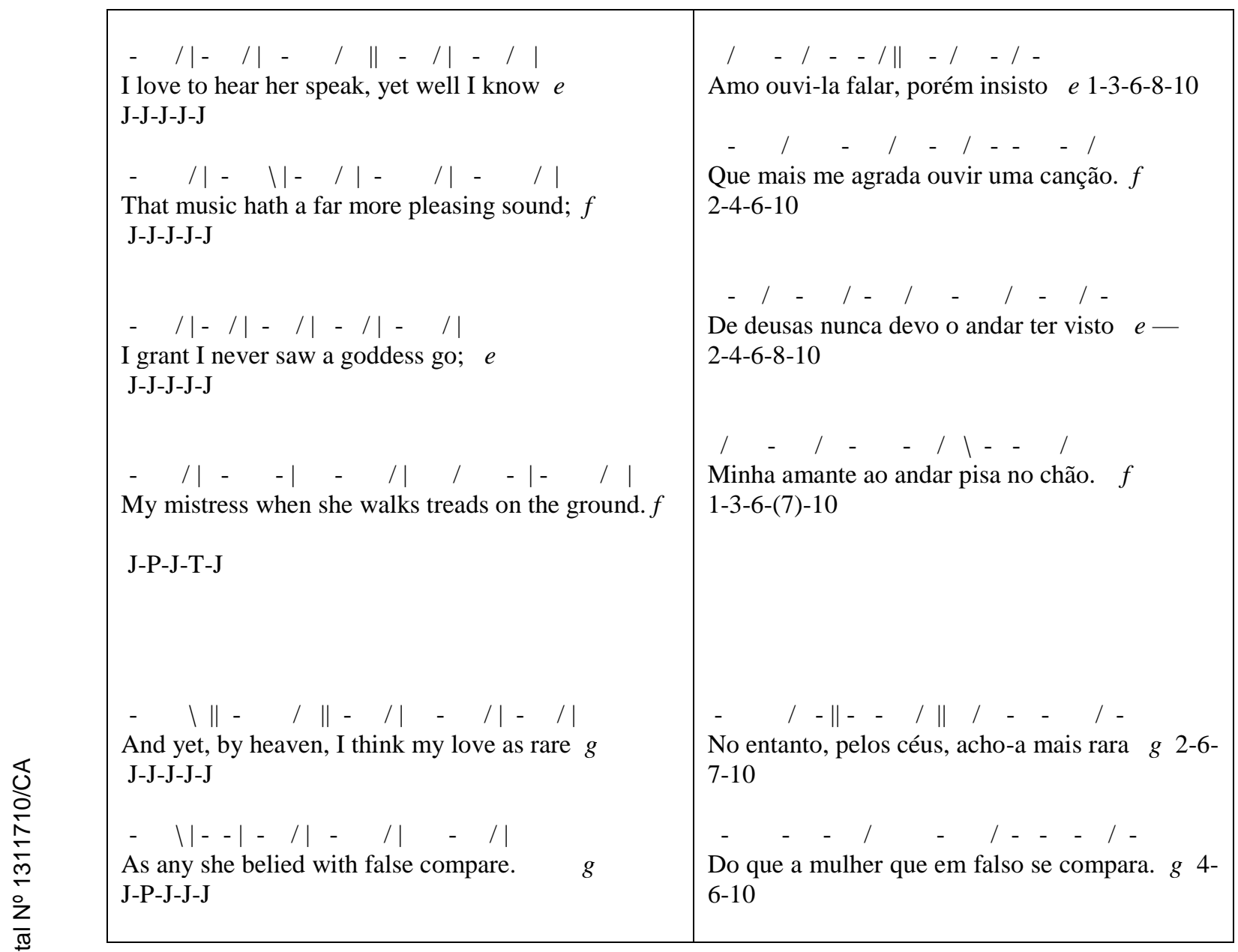

\section{6 .2}

\section{Anotação feita por AS}

My mistress' eyes are nothing like the sun;

$-/|-/|-/|-/|-/ \quad$ a J-J-J-J-J

Coral is far more red than her lips' red;

$/-|-/|-/|--| / / \quad b \quad$ T-J-J-P-E

If snow be white, why then her breasts are dun; - / - / - / - / / / a J-J-J-J-J

If hairs be wires, black wires grow on her head. $-/|-/|-/|/-|-/ \quad b \quad$ J-J-J-T-J
O seu olhar não é o de um sol puro; - - - / / - - \/ - a 4-(5)-6-(9)-10

Nenhum coral os lábios lhe acendeu; - / - / - / - - / b 2-4-6-10

Se a neve é branca, os seios tem escuros; - / / - / - / - - a 2-(3)-4-6-8-10

Se são fio os cabelos, negro é o seu.

$-\backslash /--/-/ \backslash / \quad b \quad$ (2)-3-6-8-(9)-10 


\begin{tabular}{|c|c|}
\hline $\begin{array}{l}\text { I have seen roses damasked, red and white, } \\
--|/ /|-/|-/|-/ \quad c \quad \text { P-E-J-J-J } \\
\text { But no such roses see I in her cheeks; } \\
-/|-/|-/|-/|-/ \quad d \quad d \text { J-J-J-J-J } \\
\text { And in some perfumes is there more delight } \\
-/|-/|-/|-/|-/ \quad c \quad \text { J-J-J-J-J } \\
\text { Than in the breath that from my mistress [reeks. } \\
\quad-/|-/|-/|-/|-/ \quad d \quad \text { J-J-J-J-J }\end{array}$ & 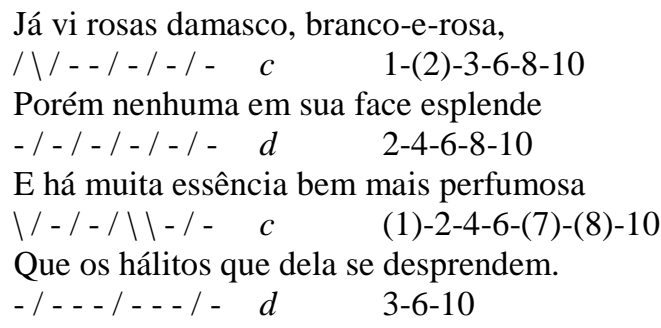 \\
\hline $\begin{array}{l}\text { I love to hear her speak, yet well I know } \\
-/|-/|-/|-/|-/ \quad e \quad \text { J-J-J-J-J } \\
\text { That music hath a far more pleasing sound; } \\
-/|-/|-/|-/|-/ \quad f \quad \text { J-J-J-J-J } \\
\text { I grant I never saw a goddess go; } \\
-/|-/|-/|-/|-/ \quad e \\
\text { J-J-J-J-J } \\
\text { My mistress when she walks treads on the ground. } \\
-/|-/|-/|/-|-I \quad f \quad J-J-J-T-J\end{array}$ & 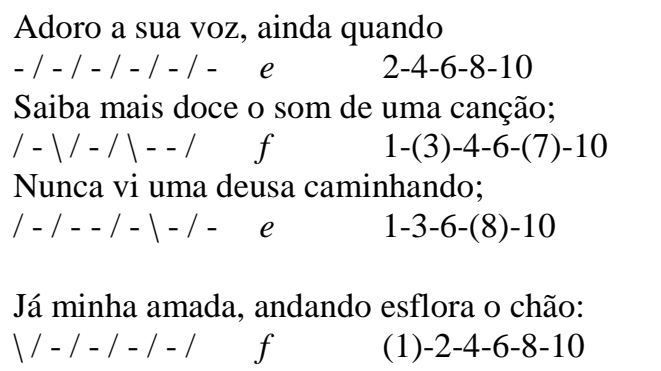 \\
\hline 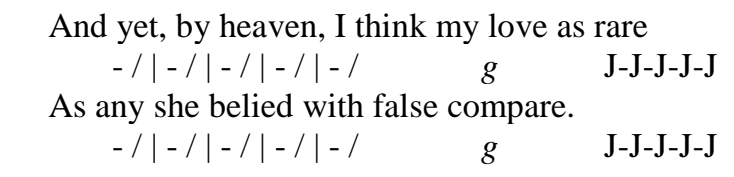 & $\begin{array}{l}\text { Mas, pelos céus, eu creio que é tão rara } \\
\backslash /-/-/-\backslash \backslash /-g \quad(1)-2-4-6-(8)-(9)-10 \\
\text { Quanto as que em falsa imagem se comparam. } \\
/--/-/---/-g \quad 1-4-6-10\end{array}$ \\
\hline
\end{tabular}

\subsection{3}

\section{Anotação feita por MM}

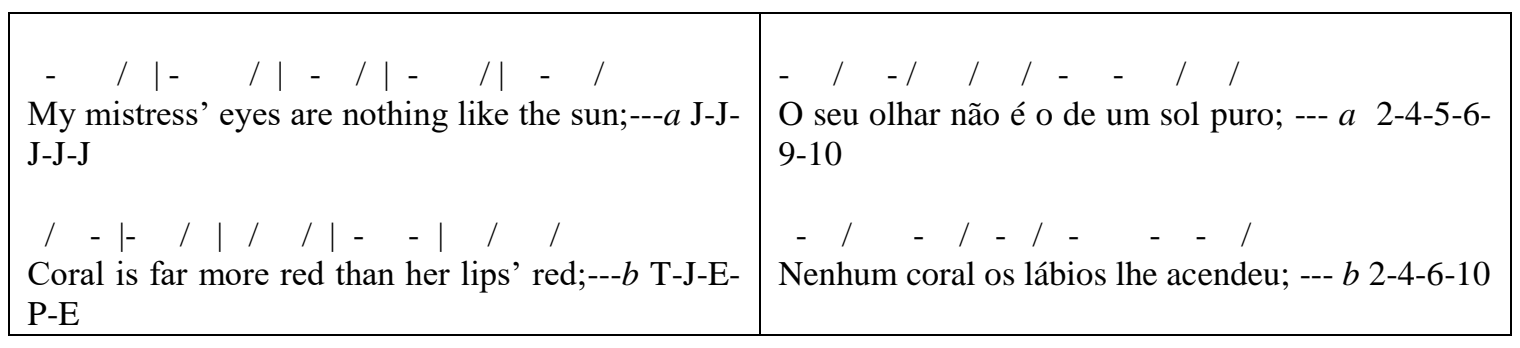




\begin{tabular}{|c|c|}
\hline $\begin{array}{l}-\quad /|-\quad| \quad|\quad|-|-| l|-| \\
\text { If snow be white, why then her breasts are dun;--- } a \\
\text { J-J-T-J-J }\end{array}$ & $\begin{array}{l}-\quad / \quad l \quad l \quad-\quad l-l-l \\
\text { Se a neve é branca, os seios tem escuros; } \\
4-6-7-10\end{array}$ \\
\hline 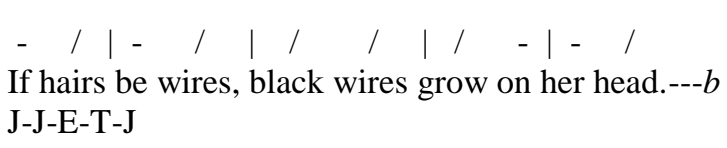 & $\begin{array}{l}-\quad / \quad / \quad-\quad / \quad-\| / \quad / \quad / \\
\text { Se são fio os cabelos, negro é o seu.-- } b \text { 2-3-6-8- } \\
9-10\end{array}$ \\
\hline $\begin{array}{l}-/|-\quad /|-\quad-|/ /|-1 / \\
\text { I have seen roses damasked, red and white,---c J-J- } \\
\text { P-E-J }\end{array}$ & $\begin{array}{l}\text { / / / - - / - } \| / \quad-\quad / \\
\text { Já vi rosas damasco, branco-e-rosa, --- c } 1 \text { 1-2-3-6-8- } \\
10\end{array}$ \\
\hline $\begin{array}{l}-/|-| /-/|/-|-\mid / \\
\text { But no such roses see } \mathrm{I} \text { in her cheeks;---d J-J-J-T-J } \\
-\quad-|/ \quad-| / \quad-|/ /|-|/| \\
\text { And in some perfumes is there more delight---c P- } \\
\text { T-T-E-J }\end{array}$ & $\begin{array}{l}-/, \quad / \quad-/-/-/ \\
\text { Porém nenhuma em sua face esplende }--d \text { 2-4-6- } \\
8-10 \\
/ \\
\text { E há muita essência bem mais perfumosa }--c \text { c 1-2- } \\
4-6-7-10\end{array}$ \\
\hline $\begin{array}{l}/ \quad-|-\quad l| l \quad l|l| l \mid \\
\text { Than in the breath that from my mistress reeks.-- } d \\
\text { T-J-J-J-J }\end{array}$ & $\begin{array}{l}-\quad /--\quad-\quad /-{ }^{-}-/ \\
\text {Que os hálitos que dela se desprendem. }--d \text { 2-6- } \\
10\end{array}$ \\
\hline $\begin{array}{l}-\quad / \quad|-\quad /|-\quad /|| l-|-| / \\
\text { I love to hear her speak, yet well I know---e J-J-J- } \\
\text { T-J }\end{array}$ & $\begin{array}{l}-/-\quad /-/ \|-/-\quad / \\
\text { Adoro a sua voz, ainda quando --- e 2-4-6-8-10 }\end{array}$ \\
\hline $\begin{array}{l}-\quad /|-||-||-\quad /|-\quad / \\
\text { That music hath a far more pleasing sound;--- } f \text { J-J- } \\
\text { J-J-J }\end{array}$ & $\begin{array}{l}/ \quad-\quad / \quad l \quad-\quad / \quad / \quad-\quad-\quad / \\
\text { Saiba mais doce o som de uma canção; }---f \text { 1-3-4- } \\
6-7-10\end{array}$ \\
\hline $\begin{array}{l}-\quad /|-||-|||-||-\quad \mid \\
\text { I grant I never saw a goddess go;---e J-J-J-J-J }\end{array}$ & 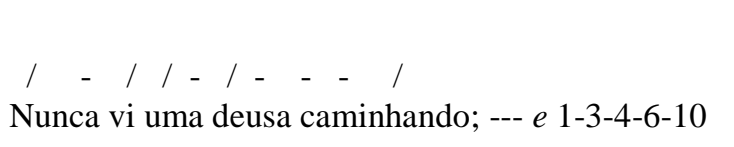 \\
\hline 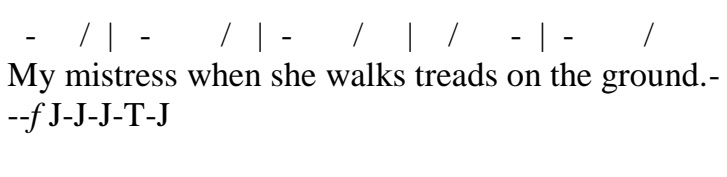 & $\begin{array}{l}\text { / I } \quad-\quad / \quad-\quad / \quad-\quad / \quad-\quad / \\
\text { Já minha amada, andando esflora o chão: } \\
4-6-8-10\end{array}$ \\
\hline $\begin{array}{l}-\quad /|-\quad /||-/|-|/|-1 \\
\text { And yet, by heaven, I think my love as rare--- } g \text { J- } \\
\text { J-J-J-J }\end{array}$ & $\begin{array}{l}-\quad / \quad-\quad / \|-\quad /-\quad / \quad / \quad / \\
\text { Mas, pelos céus, eu creio que é tão rara --- g 2-4-6- } \\
8-9-10\end{array}$ \\
\hline $\begin{array}{l}-/|--|-/|-\quad /|-1 \\
\text { As any she belied with false compare.--- } g \text { J-P-J-J- } \\
\text { J }\end{array}$ & 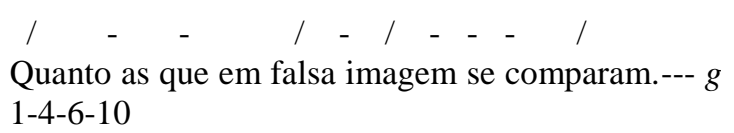 \\
\hline
\end{tabular}




\section{6 .4}

\section{Comparação das anotações e discussão dos resultados}

Notamos que, no original, temos concordância quanto ao tipo de verso utilizado no poema: para os três anotadores, o poema é escrito em pentâmetro jâmbico.

$\mathrm{Na}$ tradução, temos concordância quanto ao número de sílabas em cada verso: para os três anotadores, todos os versos são decassílabos. Tanto AS, quanto MM e eu encontramos heroicos (2-6-10) e martelos-agalopados (3-6-10). Além desses tipos, encontrei um sáfico (4-8-10): segundo verso da segunda estrofe.

Quanto ao esquema rimático, também temos concordância: para os três anotadores, a tradução reproduz o mesmo esquema do original: ababcdcdefefgg.

A partir da comparação das anotações, apesar de discordâncias nas escansões, podemos dizer que, ao traduzir os pentâmetros jâmbicos do original, o tradutor utiliza versos que tendem a padrões regulares de acentuação para os decassílabos e, quanto às rimas, o tradutor reproduz o mesmo esquema de rimas do original.

\section{7}

\section{Resultados F}

\subsection{1}

Anotação feita por JC 


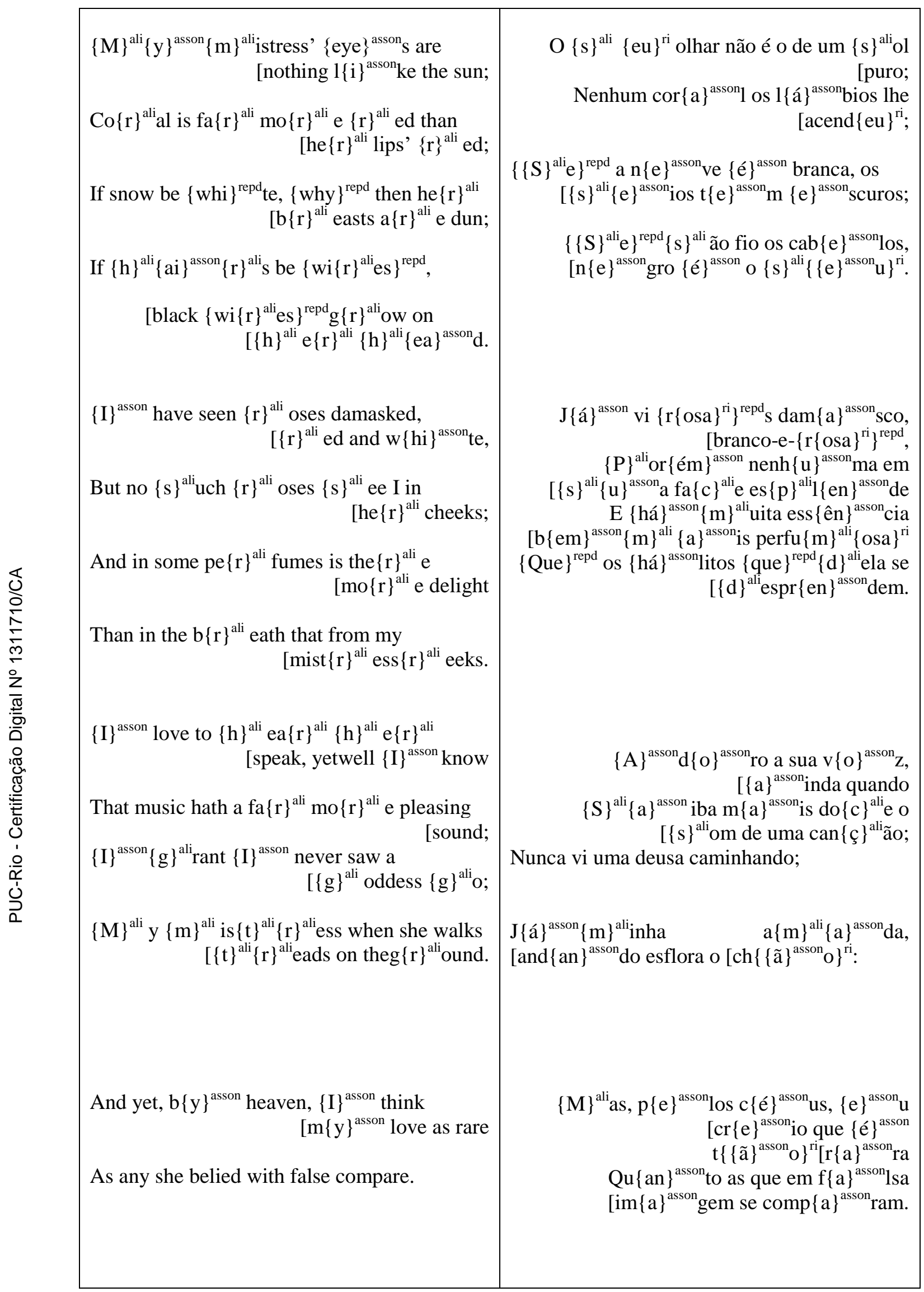




\section{7 .2}

\section{Anotação feita por AS}

$\{\mathrm{M}\}^{\text {ali }}\{\mathrm{y}\}^{\text {asson }}\{\mathrm{m}\}^{\text {ali }}$ istress' $\left._{\text {e eye }}\right\}^{\text {asson }}$ s are no $\{\text { th }\}^{\text {ali }}$ ing $1\{i\}^{\text {asson }}$ ke $\{\text { th }\}^{\text {ali }}$ e sun; $\mathrm{C}\{\mathrm{o}\}^{\text {asson }}$ ral is far $\{\mathrm{m}\}^{\text {ali }}\{\mathrm{o}\}^{\text {asson }}$ re $\{\text { red }\}^{\text {repd }}\{\text { th }\}^{\text {ali }}$ an her lips' $\{\text { red }\}^{\text {repd; }}$ If sn $\left\{\right.$ ow ${ }^{\text {asson }}\{\text { be }\}^{\text {repd }}\{\mathrm{w}\}^{\text {ali }} \mathrm{h}\{\mathrm{i}\}^{\text {asson }}$ te, $\{\mathrm{w}\}^{\mathrm{ali}} \mathrm{h}\{\mathrm{y}\}^{\text {asson }}$ then her breasts are [dun; If $\{h\}^{\text {ali }}$ airs $\{b e\}^{\text {repd }}\{\text { wires }\}^{\text {repd }}$, black $\{\text { wires }\}^{\text {repd }} \operatorname{gr}\{\text { ow }\}^{\text {asson }}$ on $\{h\}^{\text {ali }} \operatorname{er}\{h\}^{\text {ali }}$ ead.

$\{\mathrm{I}\}^{\text {asson }}\{\mathrm{h}\}^{\text {ali }}$ ave $\{\mathrm{s}\}^{\text {ali }}$ een $\{\text { roses }\}^{\text {repd }}$ damasked, red and wh $\{\mathrm{i}\}^{\text {asson }}$ te,

But no $\{\mathrm{s}\}^{\text {ali }}$ uch $\{\text { roses }\}^{\text {repd }}$ see $\{\mathrm{I}\}^{\text {asson }}$ in her cheeks;

And in $\{s\}^{\text {ali }}$ ome perfumes is $\{\text { th }\}^{\text {ali }}$ ere more $\operatorname{del}\{\mathrm{i}\}{ }^{\text {asson }}$ ght

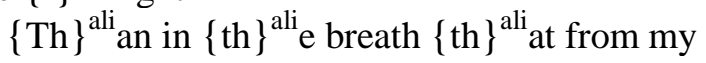
$\mathrm{m}\{\mathrm{i}\}{ }^{\text {asson }}$ stress $\left[\mathrm{r}\{\mathrm{ee}\}^{\text {asson }} \mathrm{ks}\right.$.

$\{\mathrm{I}\}^{\text {repd }}$ love to $\{\mathrm{h}\}^{\text {ali }}$ ear $\{\mathrm{h}\}^{\text {ali }}$ er speak, yet well $\{\mathrm{I}\}^{\text {repd }}$ know

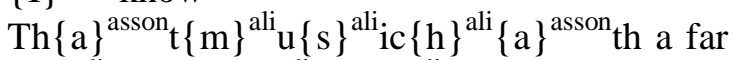
$\{\mathrm{m}\}^{\text {ali }}$ ore plea $\{\mathrm{s}\}^{\text {ali }}$ ing $\{\mathrm{s}\}^{\text {ali }}$ ound;

$\{\mathrm{I}\}^{\text {repd }}\{\mathrm{gr}\}^{\text {ali }}$ ant $\{\mathrm{I}\}^{\text {repd }}$ never $\{\mathrm{s}\}^{\text {ali }}{ }^{\text {aw }}$ a $\{\mathrm{g}\}^{\text {ali }}$ oddess $\{\mathrm{g}\}^{\text {ali }}$;

$\{\mathrm{M}\}^{\mathrm{ali}} \mathrm{y}\{\mathrm{m}\}^{\mathrm{ali}}$ istress $\{\mathrm{w}\}^{\text {ali }}$ hen she $\{\mathrm{w}\}^{\text {ali }}$ alks treads on the $[\{\mathrm{gr}\}$ ali ound.

And yet, $\mathrm{b}\{\mathrm{y}\}^{\text {asson }}$ heaven, $\{\mathrm{I}\}^{\text {asson }}$ think $\mathrm{m}\{\mathrm{y}\}^{\text {asson }}$ love as rare

As any she bel $\{\text { ied }\}^{\text {asson }}$ with false compare.
O seu $\{\mathrm{o}\}^{\text {asson }} \operatorname{lh}\{\operatorname{ar}\}^{\text {asson }}$ não é o de um sol $\mathrm{p}\{\mathrm{u}\}^{\text {asson }}$ ro;

Nenh $\{\mathrm{u}\}^{\text {asson }} \mathrm{m}$ $\left.\mathrm{c}\{\mathrm{o}\}{ }^{\text {asson }} \mathrm{ral}\{\mathrm{o}\}\right\}^{\text {asson }_{\mathrm{s}}}$ $1\{a \text { a }\}^{\text {asson }}$ bios lhe ac $\{\text { en }\}^{\text {asson }}$ deu;

$\{\mathrm{Se}\}^{\text {repd }}$ a n $\{\mathrm{e}\}^{\text {asson }}$ ve $\{\text { é }\}^{\text {asson }}$ branca, os $\mathrm{s}\{\mathrm{e}\}^{\text {asson }}{ }_{\mathrm{i}\{\mathrm{o}\}}{ }^{\text {asson }} \mathrm{s} \mathrm{t}\{\mathrm{em}\}{ }^{\text {asson }}$ escuros;

$\{\mathrm{Se}\}^{\text {repd }}$ são fi $\{0\}^{\text {asson }}$ $\left.\operatorname{cab}\{e\}^{\text {asson }} 1\{0\}\right\}^{\text {asson }}$ s, $n\{e\}^{\text {asson }} \operatorname{gr}\{\mathrm{o}\}^{\text {asson }}$ é o seu.

$J\{a ́\}^{\text {asson }}$ vi

$\left\{\operatorname{ros}\{a\}^{\text {asson }} s\right\}^{\text {repd }} d\{a\}^{\text {asson }} \mathrm{m}\{a\}^{\text {asson }}$ sco,

branco-e- $\{\text { rosa }\}^{\text {repd }}$,

Por $\{\text { ém }\}^{\text {asson }} \mathrm{n}\{\mathrm{en}\}^{\text {asson }} \mathrm{h}\{\mathrm{u}\}^{\text {asson }} \mathrm{ma}\{\mathrm{em}\}^{\text {asson }}$ sua $f\{a\}^{\text {asson }}$ ceespl $\{\text { en }\}^{\text {asson }} \mathrm{de}$

E $h\left\{a ́\right.$ asson $m\{u\}^{\text {asson }}{ }^{\text {itaess }\{\text { ên }}{ }^{\text {asson }}$ cia $\mathrm{b}\{\mathrm{em}\}^{\mathrm{asson}}$ mais perf $\{\mathrm{u}\}^{\text {asson }}$ mosa

Que os $\mathrm{h}\{\text { á }\}^{\text {asson }}$ litos que $\{\mathrm{d}\}^{\text {ali }}$ ela se $\{\mathrm{d}\}^{\text {ali }} \operatorname{espr}\{\mathrm{en}\}^{\text {asson }} \mathrm{d}\{\mathrm{em}\}^{\text {asson }}$.

$\mathrm{A}\{\mathrm{d}\}^{\text {ali }}\{\mathrm{o}\}^{\text {asson }}$ ro a sua $\mathrm{v}\{\mathrm{o}\}^{\text {asson }} \mathrm{z}$, ainda $\{\mathrm{qu}\}^{\text {ali }}\{\text { an }\}^{\text {asson }}$ do

$\{\mathrm{S}\}^{\text {ali }}\{\text { ai }\}^{\text {asson }}$ ba $\mathrm{m}\{\text { ai }\}^{\text {asson }}$ s $d\{\text { o }\}^{\text {asson }}\{\mathrm{c}\}^{\text {ali }}$ e $\mathrm{o} \quad\{\mathrm{s}\}^{\text {ali }}\{\mathrm{o}\}^{\text {asson }} \mathrm{m} \quad \mathrm{de}$ uma $\{c\}^{\text {ali }}\{\text { an }\}^{\text {asson }}\{c ̧\}^{\text {ali }}\{\text { ão }\}^{\text {asson }}$;

Nunca vi uma deusa $\{c\}^{\text {ali }}\{a\}^{\text {asson }} \operatorname{minh}\{\text { an }\}^{\text {asson }}$ do;

$J\{a\}^{\text {asson }} \operatorname{minha} \quad\{a\}^{\text {asson }} \mathrm{m}\{\mathrm{a}\}^{\text {asson }} \mathrm{da}$, $\{\text { an }\}^{\text {asson }} \mathrm{d}\{\text { an }\}^{\text {asson }}$ do es $\{f\}^{\text {ali }}$ lora $\operatorname{ch}\{\text { ão }\}^{\text {asson }}$ :

$\left.\mathrm{M}\{\mathrm{a}\}^{\text {asson }} \mathrm{s}, \quad \mathrm{p}\{\mathrm{e}\}^{\mathrm{asson}} \operatorname{los}\{\mathrm{c}\}\right\}^{\text {ali éus, }}$ $\{e\}^{\text {asson }} u\{c\}^{a^{a l i}} r\{e\}^{\text {asson }}$ io que é $t\{a \tilde{o}\}^{\text {asson }}$ $r\{a\}^{\text {asson }}$ ra

$\{q u\}^{\text {ali }}\{\text { an }\}^{\text {asson }}$ to as $\{q u\}^{\text {ali }} \mathrm{e} \quad$ em $\{f\}^{\text {ali }}\{a\}^{\text {asson }} 1\{s\}^{\text {ali }}$ aim $\{a\}^{\text {asson }}$ gem $\{c\}^{\text {ali }}$ omp $\{a\}{ }^{\text {asson }}$ ram. 


\subsection{3}

\section{Anotação feita por MM}

$\mathrm{M}\{\mathrm{y}\}^{\text {asson1 }}$ mistress' $\{\text { eyes }\}^{\text {asson1 }}$ are nothing $1\{i\}^{\text {asson1 }}$ ke the sun;

Coral is $\mathrm{fa}\{\mathrm{r}\}^{\text {ali1 }}$ more $\left\{\{\mathrm{r}\}^{\text {ali1 }} \text { ed }\right\}^{\text {repd1 }}$ than he $\{r\}^{\text {ali1 }} \operatorname{lips}^{\prime}\left\{\{r\}^{\text {ali } 1} \text { ed }\right\}^{\text {repd1 }}$;

If snow be $\{\text { whi }\}^{\text {asson1 }}$ te, $\{\text { why }\}^{\text {asson } 1}$ then her breasts are dun;

If hairs be $\left\{\right.$ wires ${ }^{\text {repd2 }}$, black $\{\text { wires }\}^{\text {repd2 }}$

grow on her head.

I have seen $\{\text { roses }\}^{\text {repd3 }}$ damasked, red and white,

But no $\{s\}^{\text {ali2 }}$ uch $\left\{\operatorname{ro}\{\text { ses }\}^{\text {ali2 }}\right\}^{\text {repd3 }}\{s\}^{\text {ali2 }}$ ee I in her cheek $\{\mathrm{s}\}{ }^{\text {ali2 }}$;

And in some perfumes is there more delight

Than in the breath that from my mistress $\{\text { reeks }\}^{\text {ril }}$.

I love to $\{\text { hear }\}^{\text {ali3 }}\{\text { her }\}^{\text {ali3 }}\left\{\right.$ speak ${ }^{\text {ri1 }}$, yet well I $\{$ know $\}$ ri2

That music hath a far more pleasing sound; I grant I never saw a $\left\{\left\{\right.\right.$ go ${ }^{\text {ali4 }}{ }^{\text {ri2 }}$ ddess $\{$ go $\}$ ali4;

My mistr $\left\{\right.$ ess ${ }^{\text {ali5 }}$ when $\{s\}^{\text {ali5 }}$ he walk $\{s\}{ }^{\text {ali5 }}$ $\operatorname{tread}\{s\}^{\text {alis }}$ on the [ground.

And yet, by heaven, I think my love as rare As any she belied with false compare.
O seu olhar não é o de um sol puro;

Nenhum cor $\{\text { al }\}^{\text {asson1 }}$ os $\{\text { lá }\}^{\text {asson1 }}$ bios lhe acendeu;

$\mathrm{S}\{\mathrm{e}\}^{\text {asson2 }}$ a $\mathrm{n}\{\mathrm{e}\}^{\text {asson2 }} \mathrm{v}\{\mathrm{e} \text { é }\}^{\text {asson2 }}$ branca, os $\mathrm{s}\{\mathrm{e}\}^{\text {asson2 }}$ ios $\mathrm{t}\{\mathrm{em}\}^{\text {asson2 }}\{\mathrm{e}\}^{\text {asson2 }}$ scuros;

Se são fio os cabelos, negro é o seu.

Já vi $\{\text { rosas }\}^{\text {repd1 }}$ damasco, branco-e- $\{$ rosa $\}$ repd1

Por $\{\text { ém }\}^{\text {asson3 }}$

$\{\mathrm{em}\}^{\text {asson3 }}\{\mathrm{s}\}^{\text {ali1 }}$ ua

$\mathrm{e}\{\mathrm{s}\}^{\text {ali } 1} \mathrm{pl}\{\mathrm{en}\}^{\text {asson } 3} \mathrm{de}$

$\mathrm{E}$ há muita e $\{\mathrm{ss}\}^{\text {ali2 }}\{\hat{e ̂ n}\}^{\text {asson3 }}\{\mathrm{c}\}^{\text {ali2 }}$ ia $\mathrm{b}\{\mathrm{em}\}^{\text {asson3 }}$ mais perfumosa

Que os hálitos que dela se
despr $\{\mathrm{en}\}^{\text {asson3 } \mathrm{d}\{\mathrm{em}\}^{\text {asson3 }}}$

Adoro a sua voz, ainda quando

$\{S\}^{\text {ali3 }}$ aiba mais do $\{c e\}^{\text {ali3 }}$ o $\{s\}^{\text {ali3 }}$ om de uma $\operatorname{can}\{c ̧\}^{\text {ali3 }}$ ão;

Nunca vi uma deusa caminhando;

Já minha amada, \{andando $\}^{\text {ri1 }}$ esflora o chão:

$\mathbf{M}\{a s\}^{\text {asson3 }}$, pelos céus, eu creio que é $\mathrm{t}\{\tilde{\mathrm{a}}\}^{\text {asson3 }}$ or $\{\mathrm{a}\}^{\text {asson3 }} \mathrm{r}\{\mathrm{a}\}^{\text {asson3 }}$

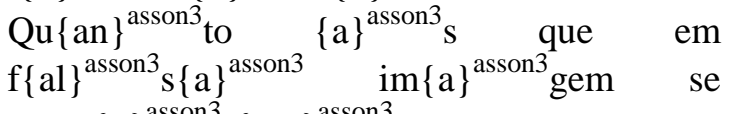
$\operatorname{comp}\{\mathrm{a}\}^{\mathrm{asson} 3} \mathrm{r}\{\mathrm{am}\}^{\text {asson3 }}$

\section{7 .4}

\section{Comparação das anotações e discussão dos resultados}

Comparando as três anotações, foi possível observar que houve recursos que um anotador anotou e outro não, tanto no original quanto na tradução. Dois exemplos disso sãoa assonância em /ai/ (by, I, my), no primeiro verso do dístico final, anotada somente por mim e por AS; e a assonância em /o/ (Adoro, voz), no primeiro verso da terceira estrofe, também anotada somente por mim e por AS. Mesmo com discordâncias como 
essas, podemos dizer que os recursos sonoros, nos poemas em inglês e em português, não têm função estruturante, diferentemente das rimas e do metro.

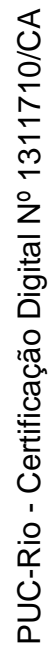




\section{Resultados da segunda etapa}

\section{1}

\section{Resultados $\mathbf{G}^{18}$}

\subsection{1}

\section{Estudo de caso 1: gabarito do nível semântico-lexical}

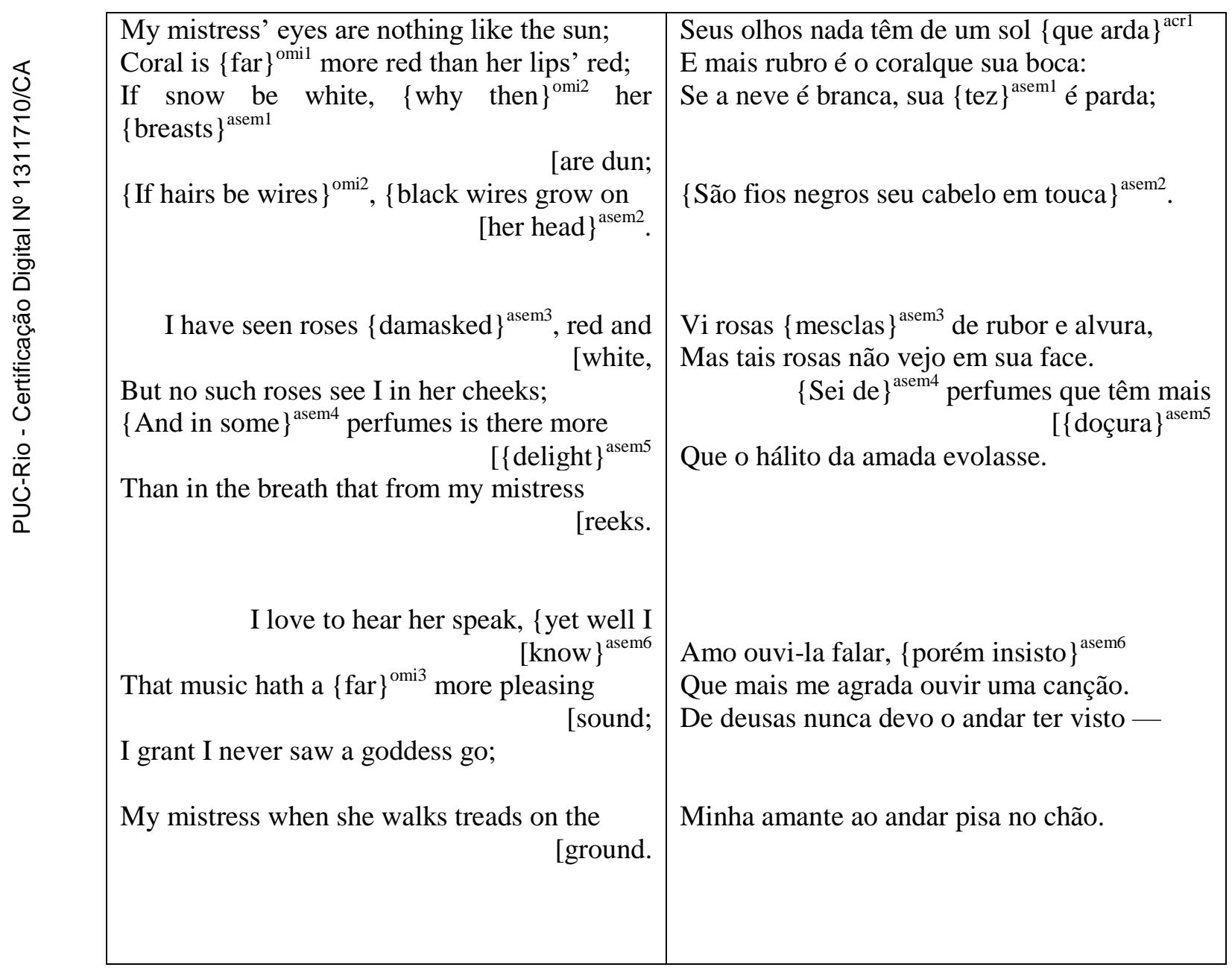

\footnotetext{
${ }^{18}$ Neste capítulo, tanto nos subcapítulos Resultados G quanto Resultados J, em Relação entre o nível formal e as categorias do nível semântico-lexical, as traduções alternativas, que não foram feitas nem por Barroso e nem por Wanderley, foram feitas por mim.
} 
And yet, by heaven, I think my love $\{$ as rare As ${ }^{\text {asem7 }}$ any she belied with false

[compare.
No entanto, pelos céus, acho-a \{ mais rara Do que $\}^{\text {asem7 }}$ a mulher que em falso se

[compara.

\section{1 .2}

\section{Relação entre o nível formal e as categorias do nível semântico-lexical}

Estratégias tradutórias que podem ter sido utilizadas para manter o verso em português com dez sílabas:

\begin{tabular}{|c|c|}
\hline $\begin{array}{l}\text { Primeira estrofe, segundo verso:omissão } \\
\text { de "far" (bem). }\end{array}$ & \\
\hline $\begin{array}{l}\text { Com omissão: } \\
/-|-||-/|--|/| / \mid \\
\text { Coral is far more red than her lips' red; } b \text { T-J-J- } \\
\text { P-E }\end{array}$ & $\begin{array}{l}-/ \backslash \quad /-/-/-/- \\
\text { E mais rubro é o coral que sua boca: } b \\
2-(3)-4-6-8-10\end{array}$ \\
\hline $\begin{array}{l}\text { Sem omissão: } \\
/-|-||-||--| /|/| \\
\text { Coral is far more red than her lips' red; } b \text { T-J-J- } \\
\text { P-E }\end{array}$ & $\begin{array}{l}-\quad-\quad / \quad / \quad / \quad-\quad / \quad-\quad /-/- \\
\text { E bem mais rubro é o coral que sua boca: } \\
\text { 3-(4)-5-7-9-11 }\end{array}$ \\
\hline $\begin{array}{l}\text { Primeira estrofe, terceiro verso:alteração } \\
\text { semântica de "breasts" (seios) para "tez", } \\
\text { e omissão de "why then" (ora então). }\end{array}$ & \\
\hline $\begin{array}{l}\text { Com alteração semântica e omissão: } \\
-\quad /|-\quad / \| / \quad-|-\quad /|-\quad /| \\
\text { If snow be white, why then her breasts are dun; } a \\
\text { J-J-T-J-J }\end{array}$ & $\begin{array}{l}-\quad / \quad|/-\| /-/| / \mid- \\
\text { Se a neve é branca, sua tez é parda; } a \\
2-(3)-4-6-8-(9)-10\end{array}$ \\
\hline 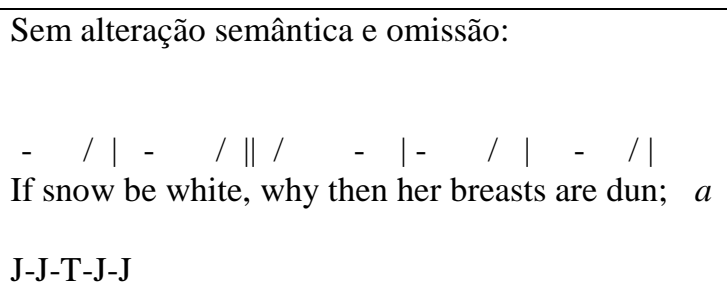 & $\begin{array}{l}-\quad / \quad / \quad / \quad-\| / \quad-\quad / \quad-\quad / \quad-\quad / \quad / \quad- \\
\text { Se a neve é branca, ora então seus seios são pardos; } \\
\text { 2-(3)- 4- 6-8-10-(12)-13 }\end{array}$ \\
\hline $\begin{array}{l}\text { Segunda estrofe, primeiro verso: alteração } \\
\text { semântica de "damasked" (damasco) para } \\
\text { "mesclas" }\end{array}$ & \\
\hline
\end{tabular}




\begin{tabular}{|c|c|}
\hline $\begin{array}{l}\text { Com alteração semântica: } \\
-\quad|/ / /|-/ \mid-\|/\|-\quad / \| \\
\text { I have seen roses damasked, red and white, } c \\
\text { J-E-J-J-J }\end{array}$ & 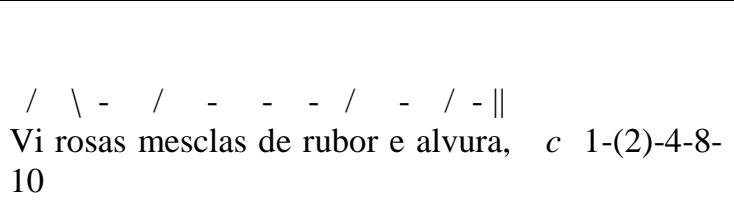 \\
\hline $\begin{array}{l}\text { Sem alteração semântica: } \\
-\quad|/ / /|-/ \mid-\|/\|-\quad / \| \\
\text { I have seen roses damasked, red and white, } c \\
\text { J-E-J-J-J }\end{array}$ & $\begin{array}{l}/ \backslash--/---/-\quad /-\| \\
\text { Vi rosas damasco de rubor e alvura, } \\
11\end{array}$ \\
\hline $\begin{array}{l}\text { Segunda estrofe, terceiro verso: alteração } \\
\text { semântica de "And [in] some" (E [em] } \\
\text { alguns) para "Sei de". }\end{array}$ & \\
\hline $\begin{array}{l}\text { Com alteração semântica: } \\
-\quad-|\backslash /|--|| /|-| / \| \\
\text { And in some perfumes is there more delight } c \text { P- } \\
\text { J-P-J-J }\end{array}$ & $\begin{array}{l}/--/-\quad-\quad \mid \quad / \quad-/-\| \\
\text { Sei de perfumes que têm mais doçura } c \\
1-4-(7)-8-10\end{array}$ \\
\hline $\begin{array}{l}\text { Sem alteração semântica: } \\
-\quad-|\backslash /|--|| /|-||| \mid \\
\text { And in some perfumes is there more delight } c \text { P- } \\
\text { J-P-J-J }\end{array}$ & $\begin{array}{l}-\quad / \quad-\quad /-1 \quad l-1-\| \\
\text { E alguns perfumes têm mais deleite } \\
2-4-6-(7)-9\end{array}$ \\
\hline $\begin{array}{l}\text { Terceira estrofe, segundo verso:omissão } \\
\text { de "far" (bem) }\end{array}$ & \\
\hline $\begin{array}{l}\text { Com omissão: } \\
-\quad /|-||-/|-\quad /|-\quad /| \\
\text { That music hath a far more pleasing sound; } f \\
\text { J-J-J-J-J }\end{array}$ & $\begin{array}{l}-\quad /-1 /-/---/ \\
\text { Que mais me agrada ouvir uma canção. } f \\
2-4-6-10\end{array}$ \\
\hline $\begin{array}{l}\text { Sem omissão: } \\
-\quad /|-\quad||-/|-\quad /|-\quad /| \\
\text { That music hath a far more pleasing sound; } f \\
\text { J-J-J-J-J }\end{array}$ & $\begin{array}{l}-\quad / \quad l \quad-\quad / \quad-\quad / \quad-\quad-\quad / \\
\text { Que bem mais me agrada ouvir uma canção. } f \\
\text { 2-(3)-5-7-11 }\end{array}$ \\
\hline
\end{tabular}

Estratégias tradutórias que podem ter sido utilizadas para formar rimas:

\begin{tabular}{|c|c|}
\hline $\begin{array}{l}\text { Segunda estrofe, terceiro verso:alteração } \\
\text { semântica de "delight" (deleite) para } \\
\text { "doçura" >> rima completa com "alvura". }\end{array}$ & \\
\hline $\begin{array}{l}\text { Com alteração semântica: } \\
\text { I have seen roses damasked, red and white } c \\
\text { And in some perfumes is there more delight } c\end{array}$ & $\begin{array}{l}\text { Vi rosas mesclas de rubor e alvura, } c \\
\text { Sei de perfumes que têm mais doçura }\end{array}$ \\
\hline
\end{tabular}




\begin{tabular}{|c|c|}
\hline $\begin{array}{l}\text { Sem alteração semântica: } \\
\text { I have seen roses damasked, red and white } c \\
\text { And in some perfumes is there more delight } c\end{array}$ & $\begin{array}{l}\text { Vi rosas mesclas de rubor e alvura, } \\
\text { E alguns perfumes têm mais deleite }\end{array}$ \\
\hline $\begin{array}{l}\text { Terceira estrofe, primeiro verso:alteração } \\
\text { semântica de "yet well I know" (porém } \\
\text { bem sei) para "porém insisto">> rima } \\
\text { completa com "visto". } \\
\text { Obs: } \\
\text { Mesmo sem a alteração semântica, o verso } \\
\text { em português se manteria com dez sílabas. }\end{array}$ & \\
\hline $\begin{array}{l}\text { Com alteração semântica: } \\
-\quad /|-||-| \|-\quad /|-||| \\
\text { I love to hear her speak, yet well I know } e \text { J-J-J-J- } \\
\text { J } \\
\text { I grant I never saw a goddess go; } e\end{array}$ & $\begin{array}{l}/ \quad-\quad /-/ \|-/-/- \\
\text { Amo ouvi-la falar, porém insisto e 1-3-6-8-10 } \\
\text { De deusas nunca devo o andar ter visto } e-\end{array}$ \\
\hline $\begin{array}{l}\text { Sem alteração semântica: } \\
-\quad /-/ / \quad / \|- \\
\text { I love to hear her speak, yet well I know e J-J-J-J- } \\
\mathrm{J} \\
\text { I grant I never saw a goddess go; } e\end{array}$ & $\begin{array}{l}/ \quad / \quad-\quad / \|-/ \quad-\quad / \\
\text { Amo ouvi-la falar, porém bem sei } 1-3-6-8-10 \\
\text { De deusas nunca devo o andar ter visto }-\end{array}$ \\
\hline
\end{tabular}

Estratégias tradutórias que podem ter sido utilizadas para manter o verso em português com dez sílabas, e também para formar rimas:

\section{Primeira estrofe, quarto verso:omissão de "If hairs be wires" (Se cabelos são fios), e}




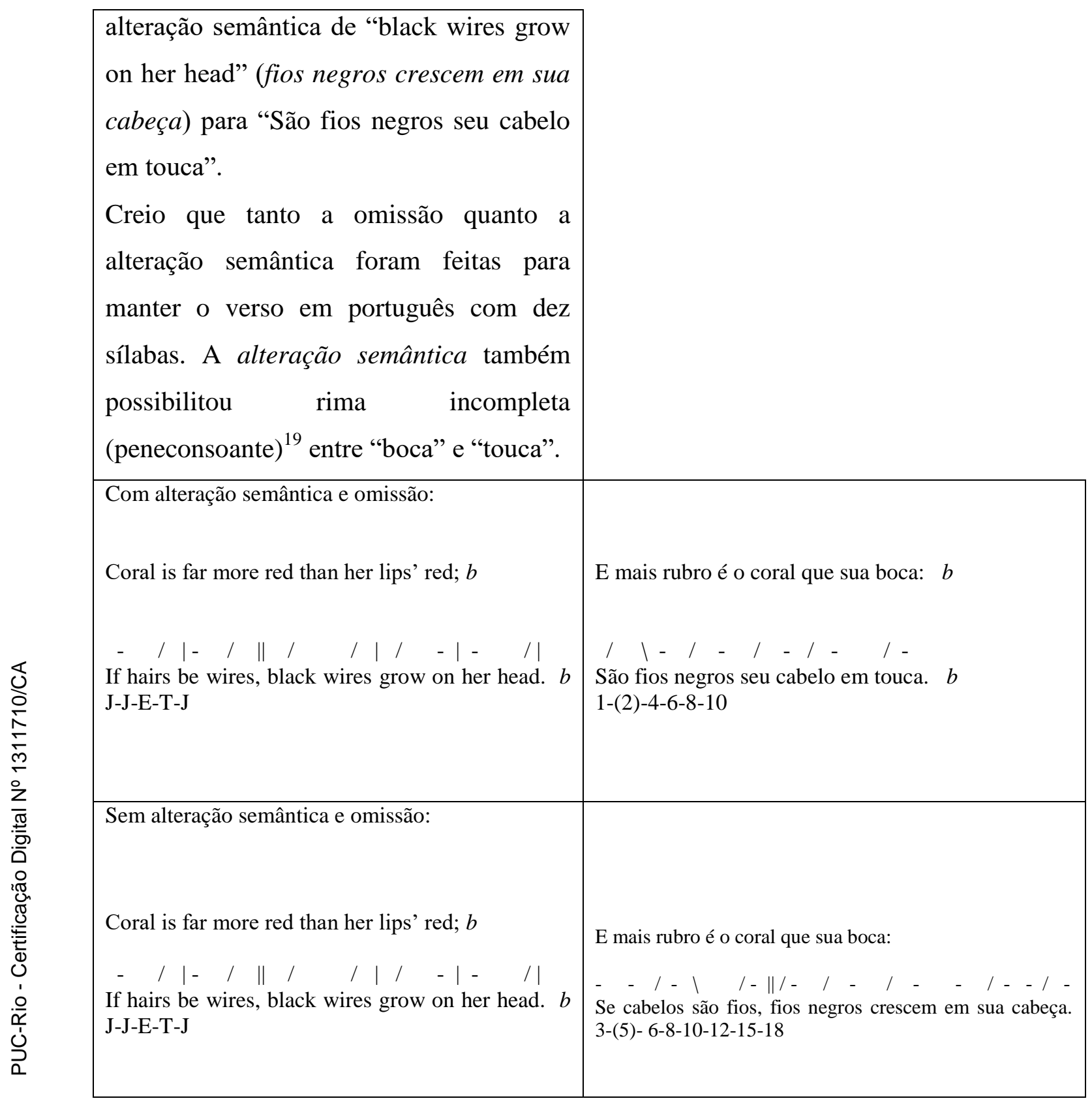

\footnotetext{
${ }^{19}$ De acordo com Nóbrega (1965), rimas peneconsoantes"mostram falta de igualdade fonética nas vogais tônicas" (p. 104). Tal denominação abrange diversos tipos de rima que apresentam essa característica. Um dos tipos apresenta "Sílabas ditongais em ou (ои, оиа, оиbа, oиса...) em rimas com sílabas em $\hat{o}(\hat{o}, \hat{o} a, \hat{o} b a, \hat{o} c a \ldots .$.$) " (ibidem, p. 113, grifos do autor). No caso em questão, temos /boka/ e$ /towka/: a sílaba ditongal de "touca" rimando com o fonema /o/, de "boca".
} 
Estratégias tradutórias que podem ter sido utilizadas para manter o verso em português com dez sílabas, para formar rima e também para reproduzir o ritmo perfeitamente jâmbico do verso original:

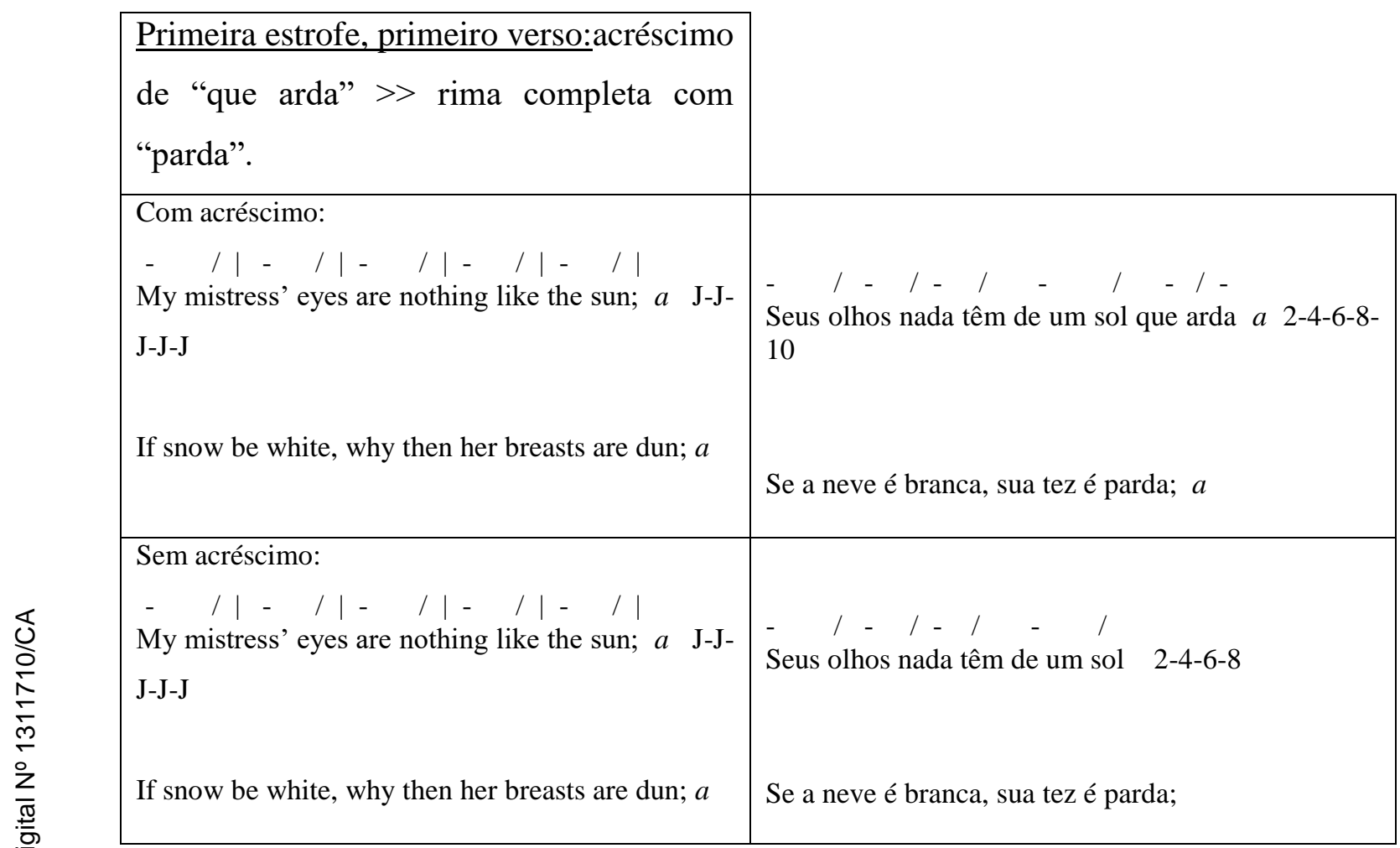

Estratégias tradutórias que não se justificam em termos formais, pois, aparentemente, não visam a manutenção do contrato métrico do poema traduzido - o decassílabo- e também não objetivam a formação de rima ${ }^{20}$ :

\begin{tabular}{|l|}
\hline Dístico final, primeiro e segundo \\
verso:alteração semântica de "as rare/ As" \\
(tão rara quanto) para "mais rara/ Do \\
que". Mesmo sem a alteração semântica, a \\
rima completa entre "rara" e "compara" \\
seria mantida, e os versos em português
\end{tabular}

${ }^{20}$ Tal estratégia será novamente verificada neste capítulo, subcapítulo Resultados I, em Possíveis relações entre o plano de recursos sonoros e as categorias do nível semântico-lexical, com base nos Resultados G. 


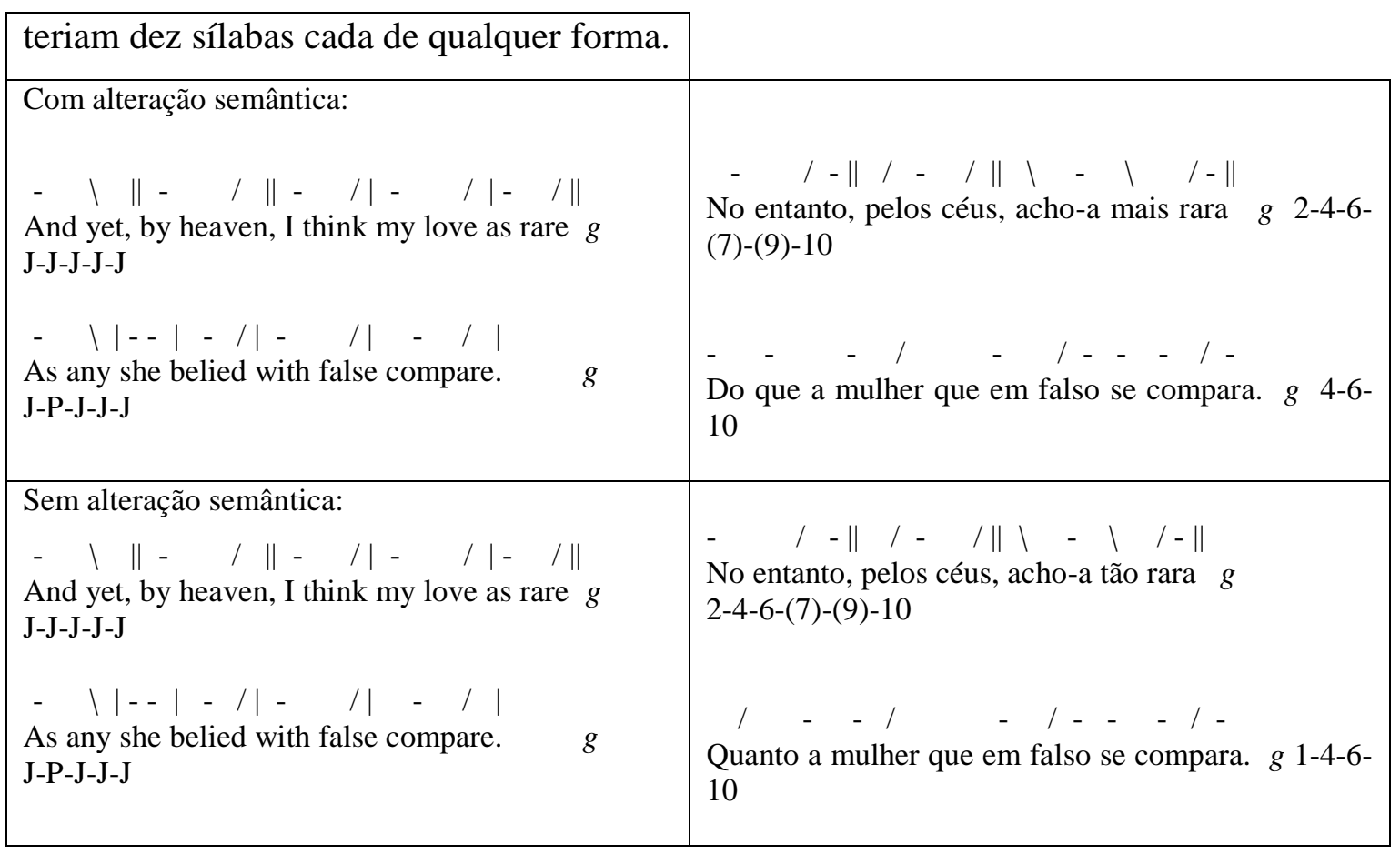

\section{2}

\section{Resultados H}

\subsection{1}

\section{Estudo de caso 1: gabarito do nível formal}

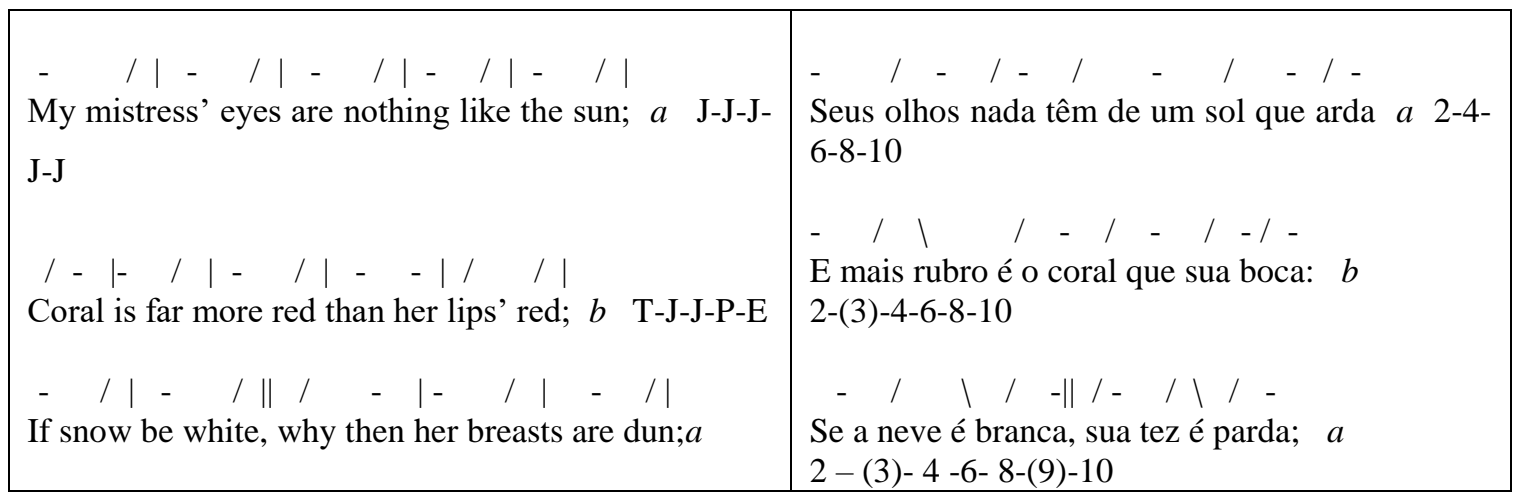




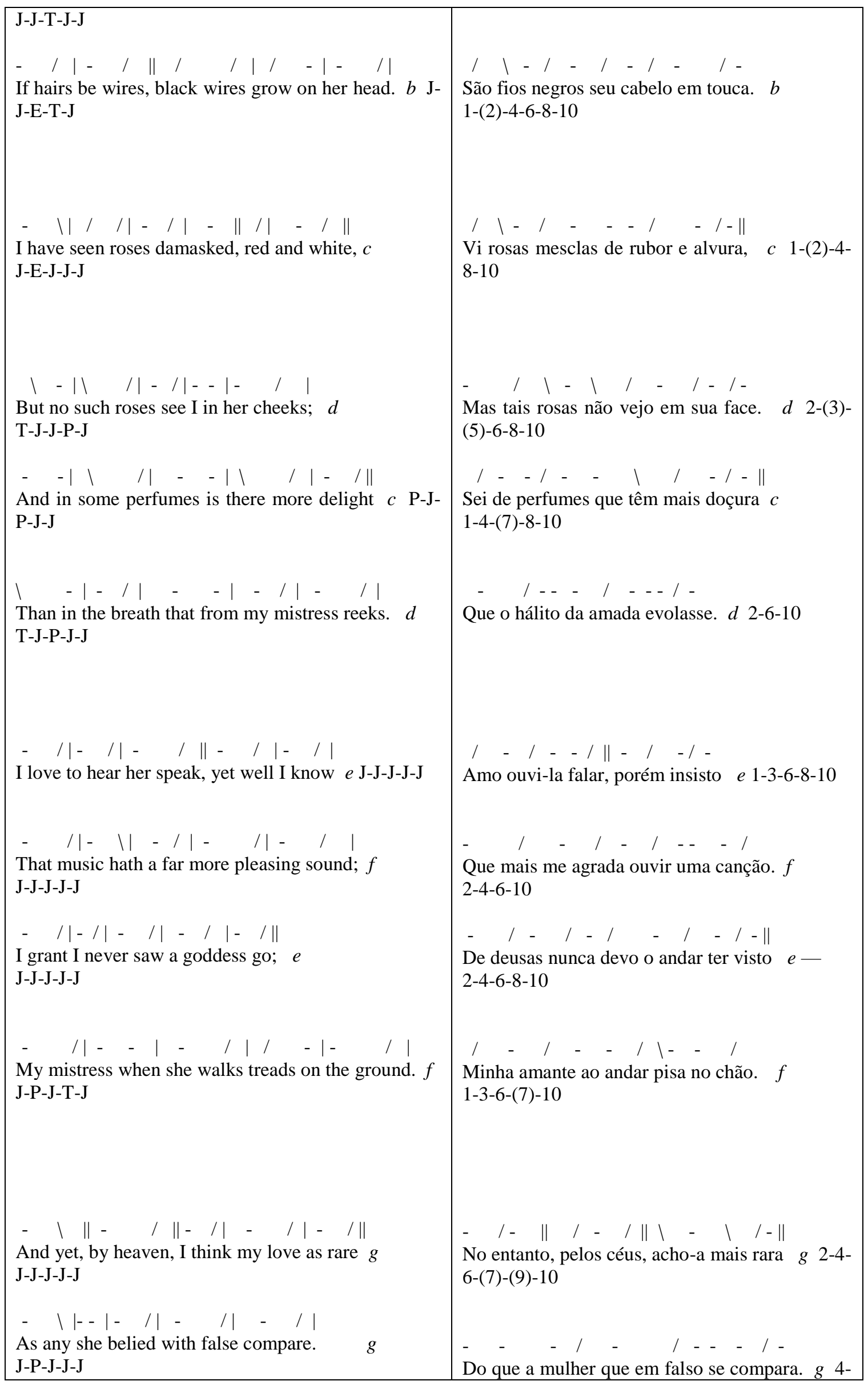




\subsection{2}

\section{Aspectos do nível formal}

O original, que é um soneto composto por três quartetos e um dístico final, totalizando 14 versos, é traduzido em um poema com essa exata estrutura. O contrato métrico do original é o pentâmetro jâmbico, apresentando muitas variações. O primeiro verso é um pentâmetro jâmbico perfeito, que só volta aparecer na segunda metade do poema: no nono, décimo, décimo primeiro e décimo terceiro verso. Na tradução, o contrato métrico é o heroico. Os únicos versos que são desviantes do contrato são o primeiro e terceiro verso da segunda estrofe - sáficos - e o primeiro e quarto verso da terceira estrofe - martelos-agalopados. Assim, podemos dizer que a tradução apresenta uma estrutura métrica mais regular que o original.

Quanto às rimas, o tradutor reproduz o mesmo esquema de rimas do original. No entanto, encontramos na tradução uma rima incompleta - peneconsoante - $(b-$ boca/touca), enquanto, no original, todas as rimas são completas.

\section{2 .3}

\section{Articulação de aspectos do nível formal com o nível semântico-lexical}

Ao longo do soneto, o eu-lírico apresenta sua amada através de comparações inusitadas, em sua maioria, com elementos da natureza. Em alguns casos, tais comparações são marcadas por pausas, tanto no original quanto na tradução:

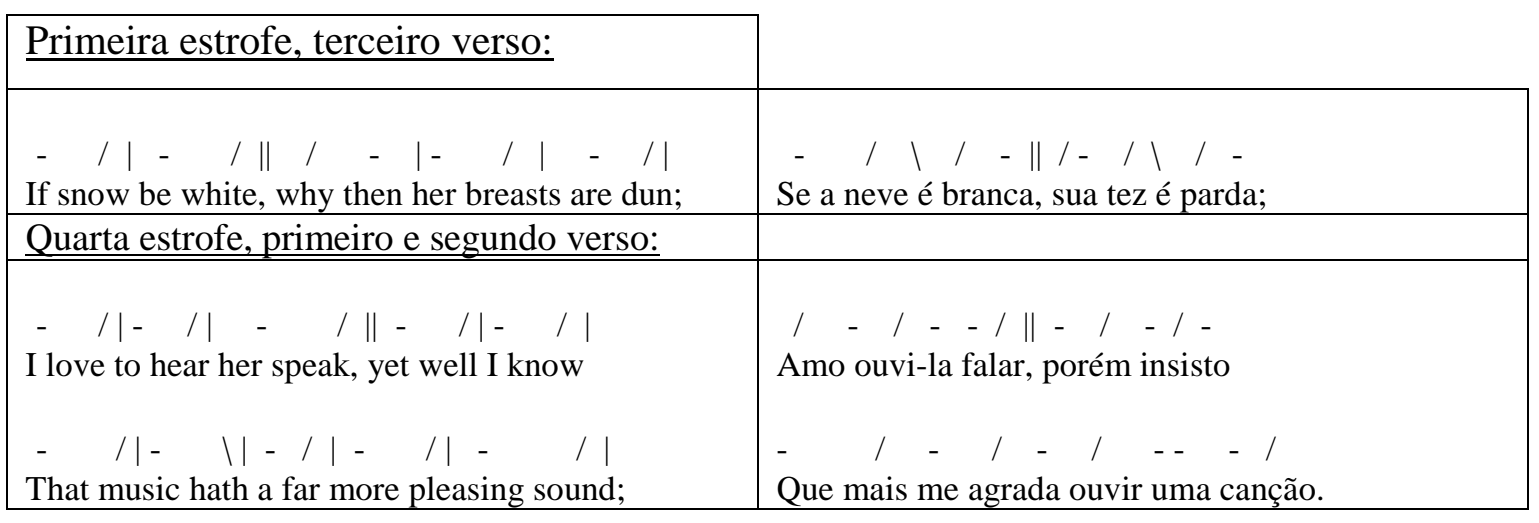




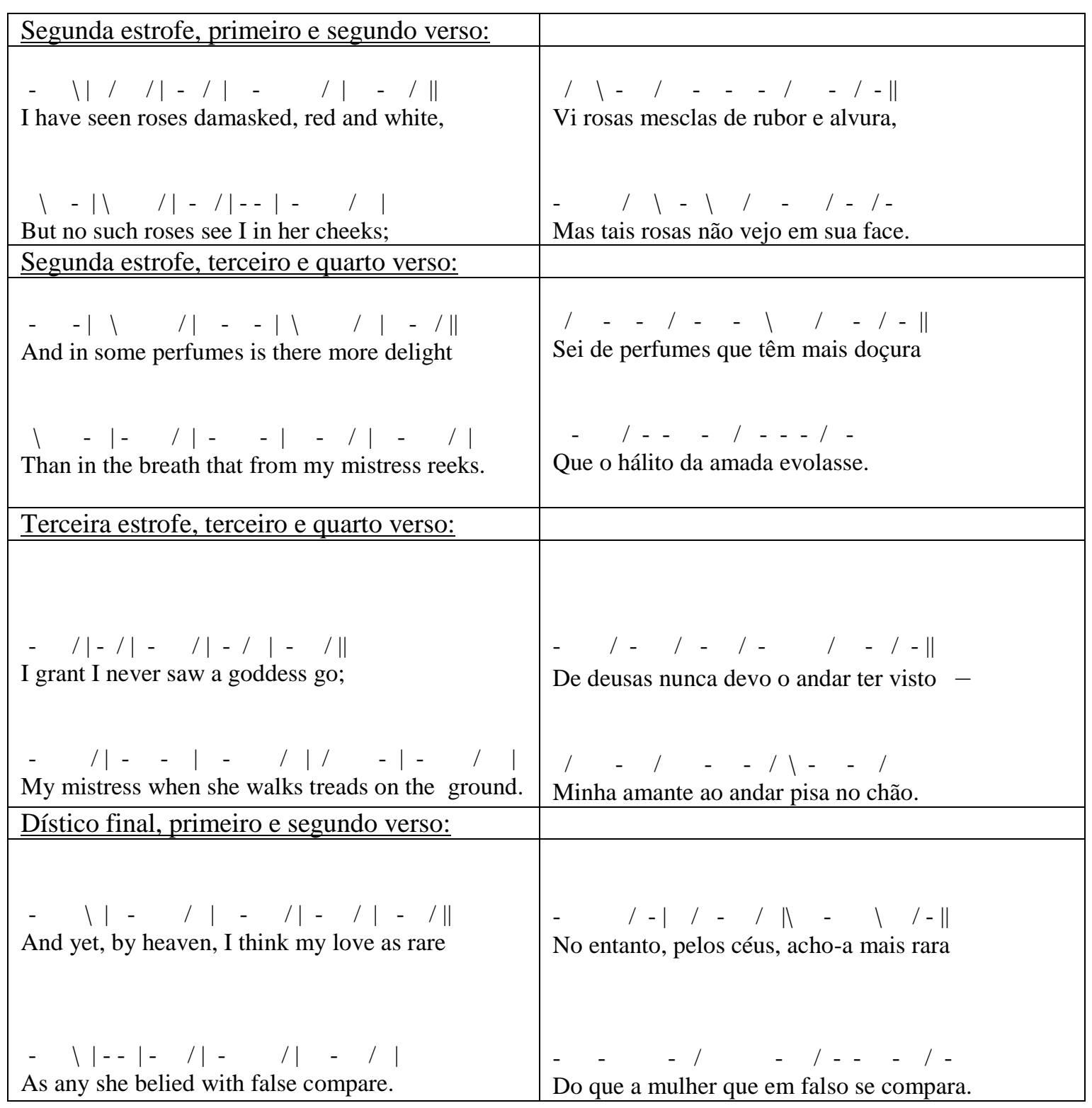

Há um caso em que somente no original a comparação é marcada com pausa:

\begin{tabular}{|c|c|}
\hline Primeira estrofe, quarto verso & \\
\hline 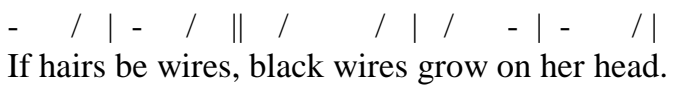 & $\begin{array}{c}/ \quad 1-I-1-1-1 \\
\text { São fios negros seu cabelo em touca. }\end{array}$ \\
\hline
\end{tabular}

Em alguns casos, a pausa, no original, não é utilizada para marcar comparações, e não tem qualquer relação com o plano semântico:

\begin{tabular}{|l|l|}
\hline $\begin{array}{l}\text { Segunda estrofe, primeiro verso: tal pausa não } \\
\text { é reproduzida na tradução. }\end{array}$ \\
\hline$-\quad|| / /|-/|-\| /|-/|$ & $/ \mid-/---/-/-$ \\
\hline
\end{tabular}




\begin{tabular}{|l|l|}
\hline I have seen roses damasked, red and white, & Vi rosas mesclas de rubor e alvura, \\
\hline $\begin{array}{l}\text { Dístico final, primeiro verso: tais pausas são } \\
\text { reproduzidas na tradução. }\end{array}$ & \\
\hline$\quad \backslash\|-\quad /\|-/|-/|-/ \mid$ & $\begin{array}{c}/-\|/-\quad /\| \backslash-\quad / / \text { - } \\
\text { No entanto, pelos céus, acho-a mais rara }\end{array}$ \\
And yet, by heaven, I think my love as rare & \\
\hline
\end{tabular}

\section{3}

\section{Resultados I}

\subsection{1}

\section{Estudo de caso 1: gabarito do plano de recursos sonoros}

\begin{tabular}{|c|c|}
\hline $\begin{array}{c}\{\mathrm{M}\}^{\text {ali }}\{\mathrm{y}\}^{\text {asson }}\{\mathrm{m}\}^{\text {ali }} \text { istress' }\{\text { eye }\}^{\text {asson }} \text { s are } \\
{\left[\text { nothing }\{1\}^{\text {ali }}\{\mathrm{i}\}^{\text {asson }}{ }^{\text {ke the sun; }}\right.}\end{array}$ & $\begin{array}{l}\{S\}^{\text {ali }} \text { eus }\{0\}^{\text {asson }}{ }^{\text {hhos } n}\{a\}^{\text {asson }} \text { da têm de um } \\
{\left[\{s\}^{\text {ali }}\{0\}^{\text {asson }} 1 \text { que }\{a\}^{\text {asson }} \text { rda }\right.}\end{array}$ \\
\hline $\begin{array}{l}\operatorname{Co}\{r\}^{\text {ali }} \text { al is fa }\{r\}^{\text {ali }} \operatorname{mo}\{r\}^{\text {ali }} \text { e }\left\{\{r\}^{\text {ali }} \text { ed }\right\}^{\text {repd }} \\
\quad\left[\text { than he }\{r\}^{\text {ali }}\{1\}^{\text {ali }} \text { ips' }\left\{\{r\}^{\text {ali }}\{e\}^{\text {asson }} d\right\}^{\text {repd }}\right.\end{array}$ & $\begin{array}{r}\text { E mais }\{r\}^{\text {ali }} \text { ubro é o }\{c\}^{\text {ali }}\{o\}^{\text {asson }}\{r\}^{\text {ali }} \text { al que } \\
{\left[\text { sua }\{b\}^{\text {ali }}\{o\}^{\text {asson }} \text { ca: }\right.}\end{array}$ \\
\hline 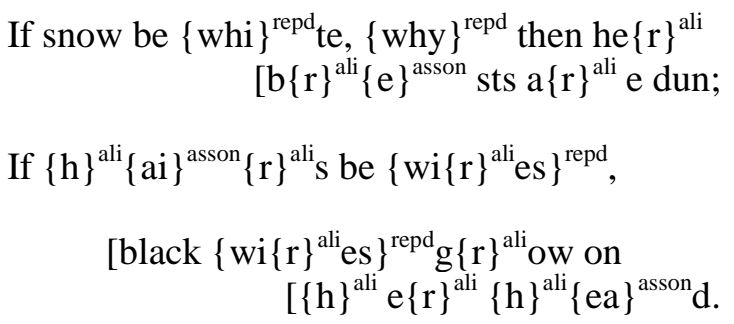 & $\begin{array}{c}\{\mathrm{S}\}^{\text {ali }} \text { e a }\left\{\{\mathrm{e}\}^{\text {asson }} \mathrm{ve}^{\text {asson }}\{\mathrm{e}\}^{\mathrm{repd}}\{\mathrm{b}\}^{\text {ali }}\{\mathrm{r}\}^{\text {ali }}\right. \\
\quad\left[\text { anca, }\{\mathrm{s}\}^{\text {ali }} \text { ua tez }\left\{\{\mathrm{e}\}^{\text {asson }}\right\}^{\text {repd }} \text { parda; }\right. \\
\{\mathrm{S}\}^{\text {ali }} \text { ão fios } n\{\mathrm{e}\}^{\text {asson }} \text { gros }\{\mathrm{s}\}^{\text {ali }}\{\mathrm{e}\}^{\text {asson }} \mathrm{u} \\
{\left[\operatorname{cab}\{\mathrm{e}\}^{\text {asson }} \text { lo em touca. }\right.}\end{array}$ \\
\hline $\begin{array}{l}\text { I have seen }\left\{\{r\}^{\text {ali }} \text { oses }^{\text {repd }}{ }^{\text {damasked, }}\right. \\
{\left[\{r\}^{\text {ali }} \text { ed and white, }\right.}\end{array}$ & $\begin{array}{r}\text { Vi }\left\{\{r\}^{\text {ali }} \text { osas }\right\}^{\text {repd }} \text { mesclas de }\{r\}^{\text {ali }} \text { ubor } \\
\text { [e alvura, }\end{array}$ \\
\hline $\begin{array}{l}\text { But no such }\left\{\{r\}^{\text {ali }} \text { oses }\right\}^{\text {repd }} \text { see I in } \\
\qquad\left[\text { he }\{r\}^{\text {ali }} \text { cheeks; }\right.\end{array}$ & $\begin{array}{r}\text { Mas tais }\left\{\{r\}^{\text {ali }} \text { osas }\right\}^{\text {repd }} \text { não vejo em sua } \\
{\left[f\{a\}^{\text {asson }} \text { ce. }\right.}\end{array}$ \\
\hline
\end{tabular}




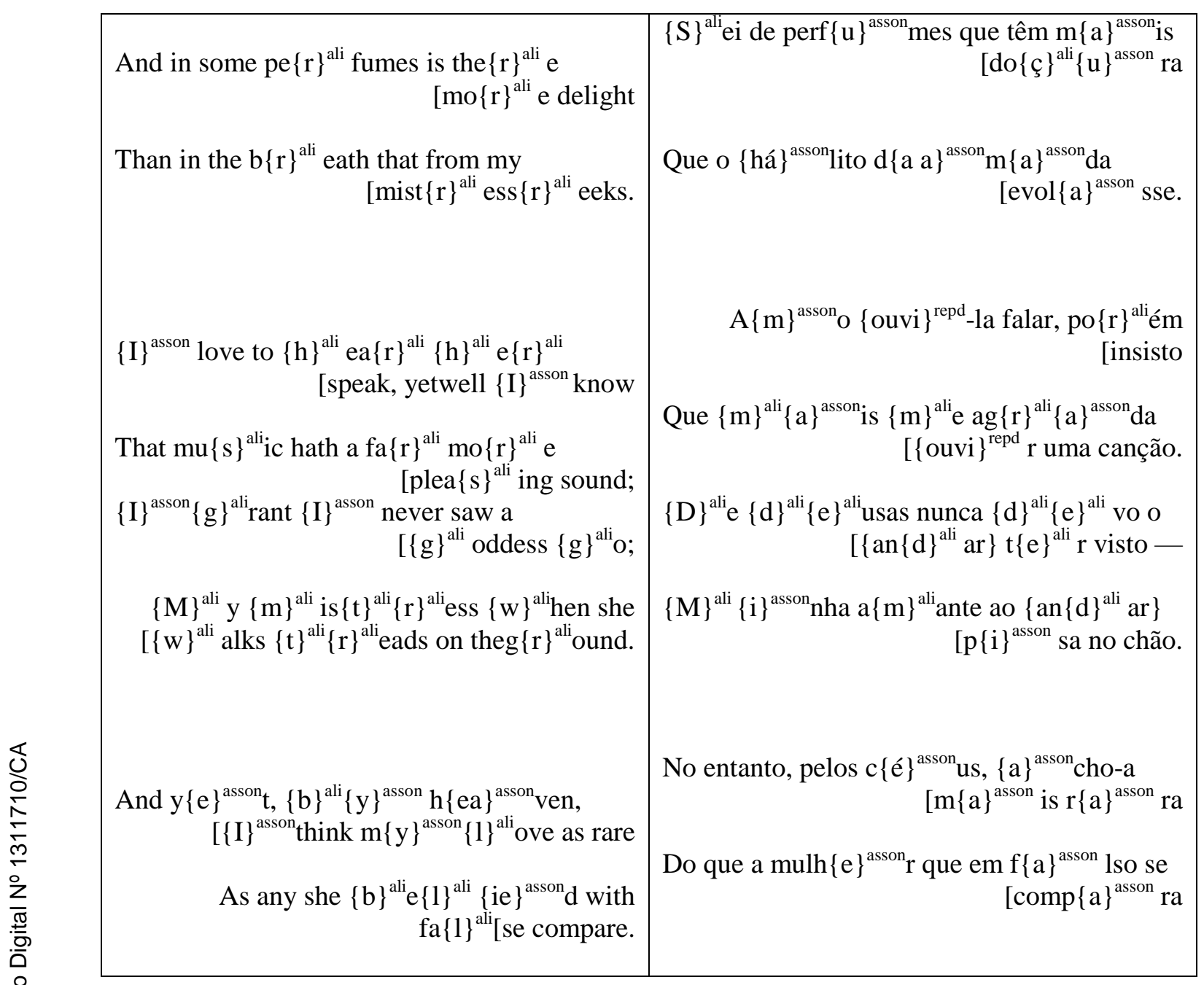

\subsection{2}

Possíveis relações entre o plano de recursos sonoros e as categorias do nível semântico-lexical, com base nos Resultados G

Estratégia tradutória que também não prioriza a reprodução de características fonológicas do original:

\begin{tabular}{|c|c|}
\hline \\
\hline \\
\hline \\
\hline & 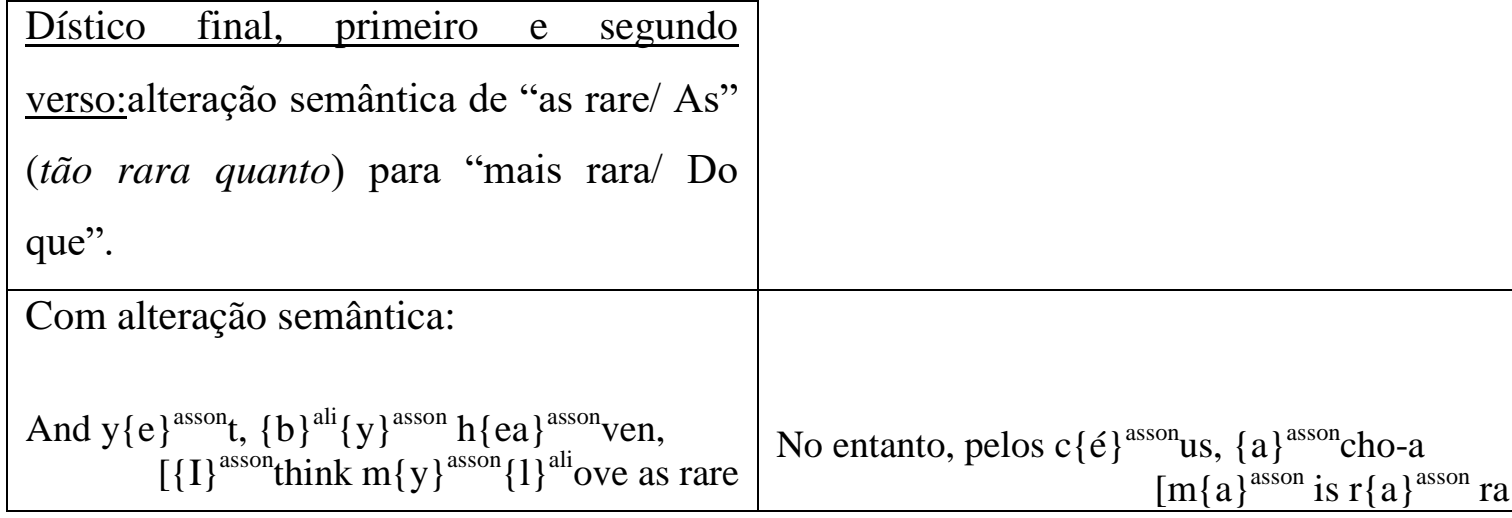 \\
\hline
\end{tabular}




\begin{tabular}{|c|c|}
\hline 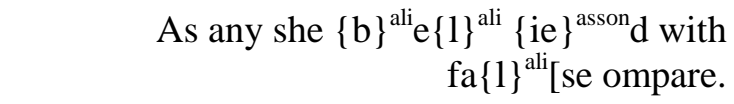 & $\begin{array}{l}\left.\text { Do que a mulh }\{\mathrm{e}\}{ }^{\text {asson }} \text { r que em } \mathrm{f}\{\mathrm{a}\}\right\}^{\text {asson }} \text { lso se } \\
{\left[\operatorname{comp}\{\mathrm{a}\}^{\text {asson }} \mathrm{ra} \text {. }\right.}\end{array}$ \\
\hline Sem alteração semântica: & \\
\hline $\begin{array}{l}\text { And } y\{e\}^{\text {asson }},\{b\}^{\text {ali }}\{y\}{ }^{\text {asson }} h\{\text { ea }\}^{\text {asson }} \text { ven, } \\
\left.\left.\qquad\{I I\}^{\text {asson }} \text { think } m\{y\}\right\}^{\text {asson }}\{1\}\right\}^{\text {ali }} \text { ove as rare }\end{array}$ & $\begin{array}{r}\text { No ent }\{\text { an }\}^{\text {asson }} \text { to, pelos c c }\{\text { é }\}^{\text {asson }} \text { us, }\{\text { a }\}^{\text {asson }} \text { cho- } \\
{\left[\text { a t }\{\tilde{a}\}^{\text {asson }} \text { or }\{\text { a }\}^{\text {asson }} \text { ra }\right.}\end{array}$ \\
\hline $\begin{array}{r}\text { As any she }\{b\}^{\text {ali }}\left\{\{1\}{ }^{\text {ali }}\{\text { ie }\}^{\text {asson }} \mathrm{d} \text { with }\right. \\
\text { fa }\{1\}^{\text {ali }}[\text { se compare. }\end{array}$ & $\begin{array}{l}\mathrm{Qu}\{\mathrm{an}\}^{\text {asson }} \text { to a mulh }\{\mathrm{e}\}^{\text {asson }} \mathrm{r} \text { que em } \\
\quad\left[\mathrm{f}\{\mathrm{a}\}^{\text {asson }} \text { lso } \operatorname{se} \operatorname{comp}\{\mathrm{a}\}^{\text {asson }} \mathrm{ra} .\right.\end{array}$ \\
\hline
\end{tabular}

No dístico do original, temos aliteração em /b/: by, belied; e /1/: love, belied, false ; assonância em /ai/ : by, I, my, belied; e em /ع/: yet, heaven. A fim de produzir uma sequência de sons semelhantes, como é feito no original, a tradução apresenta uma série de assonâncias em /a/: acho-a, mais, rara, falso, compara; e em em /E/ (céus, mulher). Mesmo sem a alteração semântica, a tradução também reproduziria uma sequência de assonâncias, até com um pouco mais de variedade: em /aN/ (entanto, tão, quanto); em / $\varepsilon /$ (céus, mulher); e em /a/: acho-a, rara, falso, compara.

\subsection{3}

\section{Articulação de aspectos do plano de recursos sonoros com o nível semântico-lexical}

Tanto no original quanto na tradução encontramos variadas aliterações, assonâncias e repetições diversas. Aponto, a seguir, alguns recursos sonoros que destacam determinados sentidos do original, e que são reproduzidos na tradução, também através de recursos sonoros:

$\mathrm{Co}\{\mathrm{r}\}^{\text {ali }}$ al is fa $\{\mathrm{r}\}^{\text {ali }} \operatorname{mo}\{\mathrm{r}\}^{\text {ali }}$ e $\left\{\{\mathrm{r}\}^{\text {ali }} \text { ed }\right\}^{\text {repd }}$ [than he $\{r\}^{\text {ali }}$ lips' $\left\{\{r\}^{\text {ali }} \text { ed }\right\}^{\text {repd }}$

E mais $\{r\}^{\text {ali }}$ ubro é o $c o\{r\}^{\text {ali }}$ al que

[suaboca:

No segundo verso da primeira estrofe, observamos, no original, aliteração em /r/ (Coral, far, more, red, her) e repetição diversa de "red". Ambos os recursos podem ter sido utilizados para enfatizar a noção da cor vermelha, rubra (red) do coral, ao compará- 
lo com os lábios da amada. Na tradução, notamos aliteração em /R/ e /f/(rubro e coral, respectivamente), que acredito ter sido utilizada para se tentar reproduzir o efeito que recursos semelhantes causam no original.

\begin{tabular}{|l|r|}
$\begin{array}{l}\text { I have seen }\left\{\{r\}^{\text {ali }} \text { oses }\right\}^{\text {repd }} \text { damasked, } \\
{\left[\{r\}^{\text {ali }} \text { ed and white, }\right.}\end{array}$ & $\begin{array}{r}\text { Vi }\left\{\{r\}^{\text {ali }} \text { osas }\right\}^{\text {repd }} \text { mesclas de }\{r\}^{\text {ali }} \text { ubor } \\
{[\text { e alvura, }}\end{array}$ \\
$\begin{array}{r}\text { But no such }\left\{\{r\}^{\text {ali }} \text { oses }\right\}^{\text {repd }} \text { see I in } \\
{\left[\text { he }\{r\}^{\text {ali }} \text { cheeks; }\right.}\end{array}$ & $\begin{array}{r}\text { Mas tais }\left\{\{r\}^{\text {ali }} \text { osas }\right\}^{\text {repd }} \text { não vejo em sua } \\
{[\text { face. }}\end{array}$ \\
\end{tabular}

No primeiro e segundo verso da segunda estrofe, observamos, no original, aliteração em /r/ (roses, red, her) e repetição diversa de "roses". Ambos os recursos podem ter sido utilizados para enfatizar a noção da cor avermelhada, rubra (red) das rosas (roses), ao compará-las com a face da amada. Na tradução, notamos aliteração em /R/ (rosas, rubor) e repetição diversa de "rosas", utilizadas, acredito, para tentar manter o efeito que recursos similares causam no original.

Em alguns casos, a tradução não mantém os efeitos causados por recursos sonoros no original, ao utilizar, também, esses tipos de recursos:

$$
\begin{aligned}
& \text { If }\{\mathrm{h}\}^{\text {ali }}\{\text { ai }\}^{\text {asson }}\{r\}^{\text {ali }} \text { s be }\left\{w i\{r\}^{\text {ali }} \text { es }\right\}^{\text {repd }}, \\
& {\left[\text { black }\left\{w i\{r\}^{\text {ali }} \text { es }\right\}^{\text {repd }} \mathrm{g}\{r\}^{\text {ali }}\right. \text { ow on }} \\
& {\left[\{\mathrm{h}\}^{\text {ali }} \text { e }\{r\}^{\text {ali }}\{h\}^{\text {ali }}\{\text { ea }\}^{\text {asson }}\right. \text { d. }}
\end{aligned}
$$

São fios $\mathrm{n}\{\mathrm{e}\}^{\text {asson }}$ gros $\mathrm{s}\{\mathrm{e}\}^{\text {asson }} \mathrm{u}$ $\left[\mathrm{cab}\{\mathrm{e}\}{ }^{\text {asson }}\right.$ lo em touca

No quarto verso da primeira estrofe, notamos, no original, aliterações em $/ \mathrm{h} /$ (hairs, her, head), e /r/ (hairs, wires, grow, her); assonância em /E/ (hairs, head); e repetição diversa de "wires". Creio que tais recursos foram utilizados para destacar a comparação dos cabelos da amada (hairs, sons de $/ \mathrm{h} /, \mathrm{r} / \mathrm{e} / \varepsilon /$ ) com fios de arames (wires). Na tradução, observamos assonância em /e/ (negros, seus, cabelo), que pode ter sido utilizada para enfatizar a ideia de que os cabelos da amada são negros. Porém, esse recurso não é usado para destacar a comparação. 


\section{4}

\section{Resultados J}

\subsection{1}

\section{Estudo de caso 2: gabarito do nível semântico-lexical}

My mistress' eyes are nothing like the sun;

$\{\text { Coral is far more red than her lips' red }\}^{\text {asem1; }}$ If snow be white, $\{\text { why then }\}^{\text {omil }}$ her breasts [are dun;

If hairs be wires, black wires \{grow on her [head. $]^{\text {asem2 }}$

I have seen roses damasked, red and white, But no such roses $\{\text { see I }\}^{\text {asem3 }}$ in her cheeks;

And in some perfumes is there more $\left[\{\text { delight }\}^{\text {asem } 4}\right.$

Than in the breath that from my mistress [reeks.

I love to hear her speak, yet $\{\text { well }\}^{\text {omi2 }}$ I know That music $\left\{\right.$ hath ${ }^{\text {omi3 }}$ a $\{\text { far }\}^{\text {omi4 }}$ more $\{\text { I grant }\}^{\text {omis }}$ I never saw a goddess go; [pleasing sound; My mistress when she walks $\{\text { treads }\}^{\text {asem5 }}$ on [the ground.

And yet, by heaven, I think my love as rare
O seu olhar não é o de um sol \{puro $\}^{\text {acrl}}$; $\{\text { Nenhum coral os lábios lhe acendeu }\}^{\text {asem1; }}$; Se a neve é branca, os seios tem escuros;

Se são fio os cabelos, negro $\{\text { é o seu }\}^{\text {asem2 }}$.

Já vi rosas damasco, branco-e-rosa, Porém nenhuma em sua face $\{\text { esplende }\}^{\text {asem3 }}$ E há muita essência $\{\text { bem }\}^{\text {acr2 }}$ mais $\left[\{\text { perfumosa }\}^{\text {asem4 }}\right.$

Que os hálitos que dela se desprendem.

Adoro a sua voz, ainda quando

Saiba mais doce o som de uma canção;

Nunca vi uma deusa caminhando; Já minha amada, andando \{esflora ${ }^{\text {asem5 }} \mathrm{o}$ [chão:

Mas, pelos céus, eu creio que é tão rara 


\begin{tabular}{|c|c|}
\hline $\begin{array}{l}\text { As }\{\text { any she belied with false } \\
\qquad[\text { compare }\}^{\text {asem6 }} .\end{array}$ & $\begin{array}{r}\text { Quanto \{as que em falsa imagem se } \\
\text { [comparam }\}^{\text {asem6 }} .\end{array}$ \\
\hline
\end{tabular}

\section{4 .2}

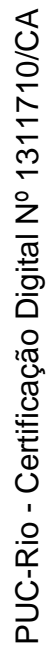

\section{Relação entre o nível formal e as categorias do nível semântico-lexical}

Estratégias tradutórias que podem ter sido utilizadas para manter o verso em português com dez sílabas:

\begin{tabular}{|c|c|}
\hline $\begin{array}{l}\text { Primeira estrofe, segundo verso:o verso } \\
\text { sofre alteração semântica. }\end{array}$ & \\
\hline $\begin{array}{l}\text { Com alteração semântica: } \\
/-|-/|-/|--| / /|| \\
\text { Coral is far more red than her lips' red; } b \text { T-J-J- } \\
\text { P-E }\end{array}$ & 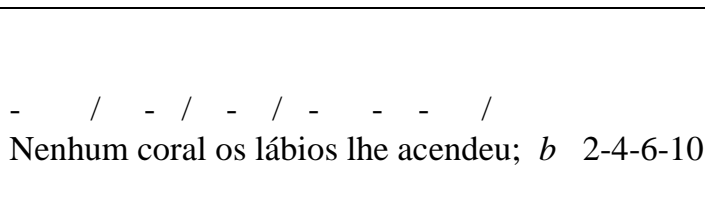 \\
\hline $\begin{array}{l}\text { Sem alteração semântica: } \\
/-|-/|-/|--| /|/| \\
\text { Coral is far more red than her lips' red; } b \text { T-J-J- } \\
\text { P-E }\end{array}$ & $\begin{array}{l}-\quad-/ \backslash / \quad \text { I / } /-\quad-\quad-\quad / \text { - } \\
\text { E o coral é bem mais rubro que seus lábios } \\
3-(4)-5-(6)-7-11\end{array}$ \\
\hline $\begin{array}{l}\text { Primeira estrofe, terceiro verso:omissão } \\
\text { de "why then" (ora então). }\end{array}$ & \\
\hline $\begin{array}{l}\text { Com omissão: } \\
-\quad /|\quad / \| / \quad-\quad|-\quad /|-\quad /| \\
\text { If snow be white, why then her breasts are dun; } a \\
\text { J-J-T-J-J }\end{array}$ & $\begin{array}{l}-\quad / \quad / \quad / \quad-\quad /-\quad / \quad-/ \quad- \\
\text { Se a neve é branca, os seios tem escuros; } a \\
\text { 2-(3)-4-6-8-10 }\end{array}$ \\
\hline Sem omissão: & \\
\hline
\end{tabular}




\begin{tabular}{|c|c|}
\hline $\begin{array}{l}-/|\quad-\|/\| / \quad-|-/|-/| \\
\text { If snow be white, why then her breasts are dun; } a \\
\text { J-J-T-J-J }\end{array}$ & 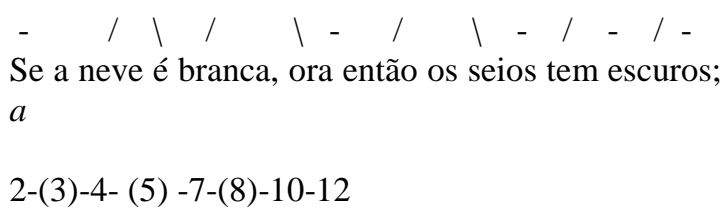 \\
\hline $\begin{array}{l}\text { Primeira estrofe, quarto verso:alteração } \\
\text { semântica de "grow on her head" } \\
\text { (crescem em sua cabeça) para "é o seu". }\end{array}$ & \\
\hline $\begin{array}{l}\text { Com alteração semântica: } \\
-\quad /|-\quad / \| / / /| / \quad-|-\quad /| \\
\text { If hairs be wires, black wires grow on her head. } b \\
\text { J-J-E-T-J }\end{array}$ & $\begin{array}{l}-\quad / \quad 1-\quad-/-\| / \quad / \quad / \\
\text { Se são fio os cabelos, negro é o seu. } b \\
\text { 2-(3)-6-8 -(9)-10 }\end{array}$ \\
\hline $\begin{array}{l}\text { Sem alteração semântica: } \\
\text { - / | }-/ \| / / /|/ \quad-|-/ \mid \\
\text { If hairs be wires, black wires grow on her head. } b \\
\text { J-J-E-T-J }\end{array}$ & 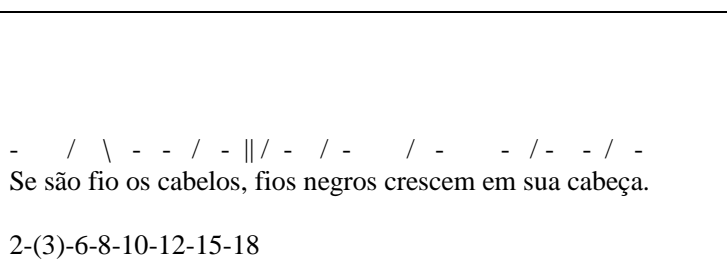 \\
\hline $\begin{array}{l}\text { Terceira estrofe, quarto verso:alteração } \\
\text { semântica de "treads" (pisa com força) } \\
\text { para "esflora". }\end{array}$ & \\
\hline $\begin{array}{l}\text { Com alteração semântica: } \\
\begin{array}{l}\text { My mistress when she walks treads on the ground. } \\
f \quad \text { J-P-J-T-J }\end{array}\end{array}$ & 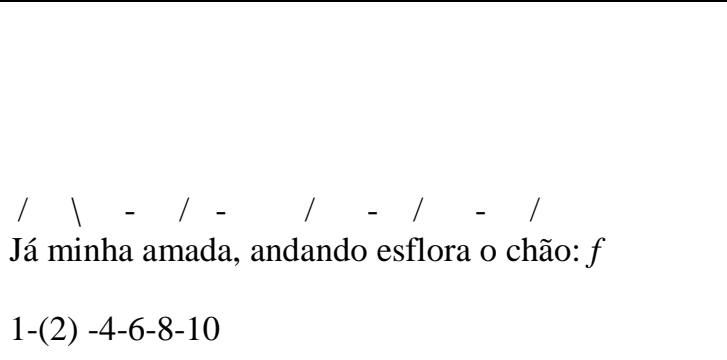 \\
\hline $\begin{array}{l}\text { Sem alteração semântica: } \\
\text { My mistress when she walks treads on the ground. } \\
f \text { J-P-J-T-J }\end{array}$ & $\begin{array}{l}/ \quad \backslash-/ / \quad /-/--/ \\
\text { Já minha amada, andando pisa no chão: } f \\
1-(2)-4-6-8-11\end{array}$ \\
\hline
\end{tabular}


Estratégias tradutórias que podem ter sido utilizada para formar rimas:

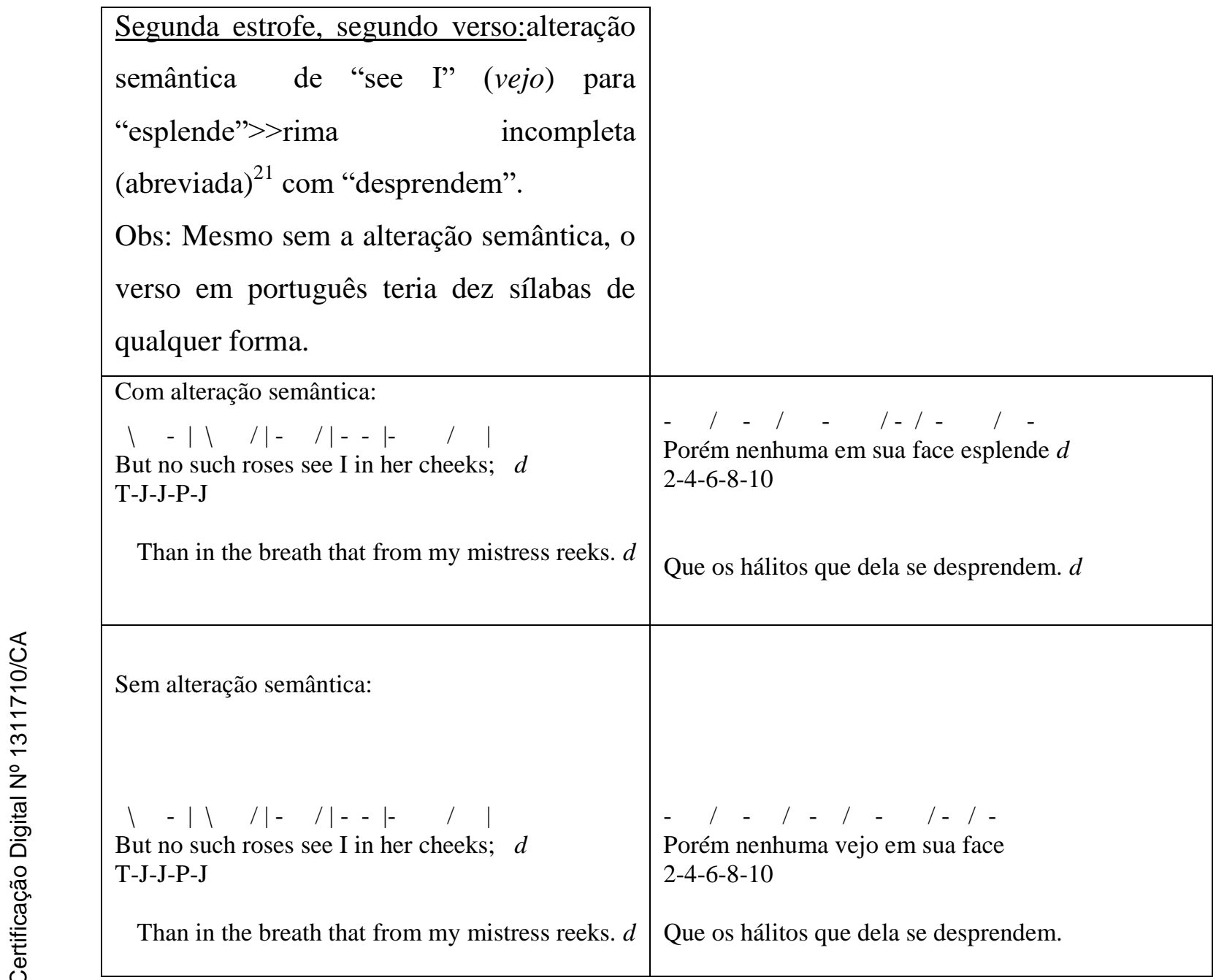

Estratégias tradutórias que podem ter sido utilizadas para manter o verso em português com dez sílabas, e também para formar rimas:

\begin{tabular}{|l|l|}
\hline Primeira estrofe, primeiro verso:acréscimo & \\
de "puro" $>>$ rima incompleta (toante) $)^{22}$ & \\
com "escuros". & \\
\hline Com acréscimo: & \\
\hline
\end{tabular}

${ }^{21}$ Esse tipo de rima abreviada ocorre entre paroxítonas que têm a mesma tônica: esplende/ desprendem. Para mais informações sobre rimas abreviadas, conferir LIRA (2000).

22“"A rima toante consiste na reiteração das vogais a partir da última forte dos versos” (CHOCIAY, 1974, p.180, grifo do autor). 


\begin{tabular}{|c|c|}
\hline $\begin{array}{l}-/|-| /|-||-| /|-| \mid \\
\text { My mistress' eyes are nothing like the sun; } a \text { J-J- } \\
\text { J-J-J } \\
\text { If snow be white, why then her breasts are dun; } a\end{array}$ & $\begin{array}{l}-\quad /-1 \quad / \quad / \quad-\quad-\quad / \quad /- \\
\text { O seu olhar não é o de um sol puro; } a \\
\text { 2-4-(5)-6- (9)-10 } \\
\text { Se a neve é branca os seios tem escuros: }\end{array}$ \\
\hline & \\
\hline $\begin{array}{l}\text { Sem acréscimo: } \\
-/|-/|-/|-| /|| \mid \\
\text { My mistress' eyes are nothing like the sun; } a \text { J-J- } \\
\text { J-J-J } \\
\text { If snow be white, why then her breasts are dun; } a\end{array}$ & $\begin{array}{l}-\quad / \quad-\quad / \quad / \quad-\quad-\quad / \\
\text { O seu olhar não é o de um sol; } \\
\text { 2-4-(5)-6-9 }\end{array}$ \\
\hline
\end{tabular}

Estratégias tradutórias que podem ter sido utilizadas para manter o verso em português com dez sílabas, para formar rima e também para reproduzir o ritmo perfeitamente jâmbico do verso original:

\begin{tabular}{|c|c|}
\hline $\begin{array}{l}\text { Terceira estrofe, três primeiros } \\
\text { versos:omissões: no primeiro, de "well" } \\
\text { (bem); no segundo, de "hath" (tem) e } \\
\text { "far" (bem); e no terceiro, de "I grant" (Eu } \\
\text { reconheço que). } \\
\text { Acredito que todas essas omissões podem } \\
\text { ter sido feitas para manter o verso em } \\
\text { português com dez sílabas. No primeiro } \\
\text { verso, ainda, a omissão de "well" pode ter } \\
\text { permitido a reprodução do ritmo } \\
\text { perfeitamente jâmbico do original, e a } \\
\text { rima completa entre "quando" e } \\
\text { "caminhando". No segundo verso, talvez } \\
\text { possamos dizer, ainda, que a omissão de } \\
\text { "hath" (tem) permitiu a rima completa } \\
\text { entre "canção" e "chão". }\end{array}$ & \\
\hline $\begin{array}{l}\text { Com omissões: } \\
-/|-/|-|\|-/|-|| \\
\text { I love to hear her speak, yet well I know } e \\
\text { J-J-J-J-J } \\
-\quad /|-\quad||-/|-\quad /|-\quad /| \\
\text { That music hath a far more pleasing sound; } f\end{array}$ & $\begin{array}{l}-\quad / \quad / \quad / \|-/ \quad \text { - / } \\
\text { Adoro a sua voz, ainda quando } e \\
2-4-6-8-10 \\
/ \quad-\quad / \quad / \quad-\quad / \quad-\quad-\quad-\quad / \\
\text { Saiba mais doce o som de uma canção; } f \\
\text { 1-(3)-4-6-10 }\end{array}$ \\
\hline
\end{tabular}




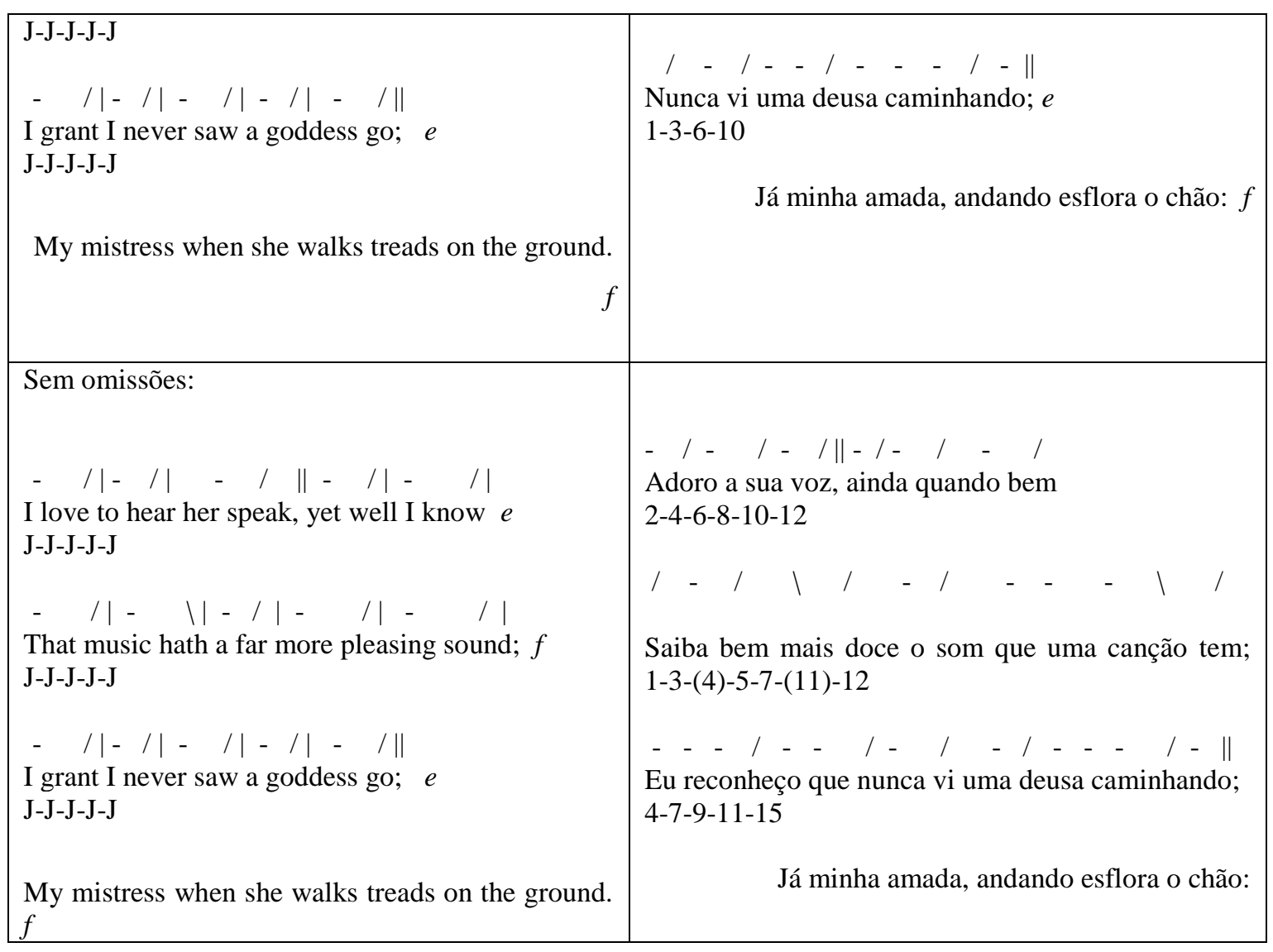

Estratégias tradutórias que não se justificam em termos formais, pois, aparentemente, não visam a manutenção do contrato métrico do poema traduzido - o decassílabo - e também não objetivam a formação de rima ${ }^{23}$ :

Segunda estrofe, terceiro verso:alteração
semântica de "delight" (deleite) para
"perfumosa", e acréscimo de "bem".
Mesmo sem a alteração semântica e sem o
acréscimo, o verso em português teria dez
sílabas de qualquer modo, e a rima
completa com "rosa" poderia ser mantida,
se "delight" fosse traduzido por

${ }^{23}$ Tais estratégias serão novamente verificadas neste capítulo, subcapítulo Resultados M, em Possíveis relações entre o plano de recursos sonoros e as categorias do nível semântico-lexical, com base nos Resultados J. 


\begin{tabular}{|c|c|}
\hline "deliciosa". & \\
\hline $\begin{array}{l}\text { Com alteração semântica e acréscimo: } \\
\text { I have seen roses damasked, red and white, } c \\
\text { And in some perfumes is there more delight } c \\
\text { P-J-P-J-J }\end{array}$ & $\begin{array}{l}\text { Já vi rosas damasco, branco-e-rosa, } c \\
/ \quad \backslash-\quad / \quad-\quad / \quad \backslash--/-\| \\
\text { E há muita essência bem mais perfumosa } c \\
\text { 1-(2)-4-6-(7)-10 }\end{array}$ \\
\hline $\begin{array}{l}\text { Dístico final, segundo verso:alteração } \\
\text { semântica de "any she belied with false } \\
\text { compare" (as que em falsa imagem [ela] } \\
\text { se compara) para "as que em falsa } \\
\text { imagem se comparam".Mesmo sem a } \\
\text { alteração semântica, o verso em português } \\
\text { teria dez sílabas de qualquer forma; e a } \\
\text { rima g - incompleta (abreviada) }{ }^{24} \text { entre } \\
\text { "rara" e "comparam" - } \\
\text { seria completa, entre "rara" e "compara". }\end{array}$ & $\begin{array}{l}\text { Já vi rosas damasco, branco-e-rosa, } c \\
/ \quad \backslash-/-/ /--/ \| \\
\text { E há muita essência mais deliciosa } c \\
\text { 1-(2)-4-6-(7)-10 }\end{array}$ \\
\hline $\begin{array}{l}\text { Com alteração semântica: } \\
\text { And yet, by heaven, I think my love as rare } g \\
\text { As any she belied with false compare. } \\
\text { J-P-J-J-J }\end{array}$ & 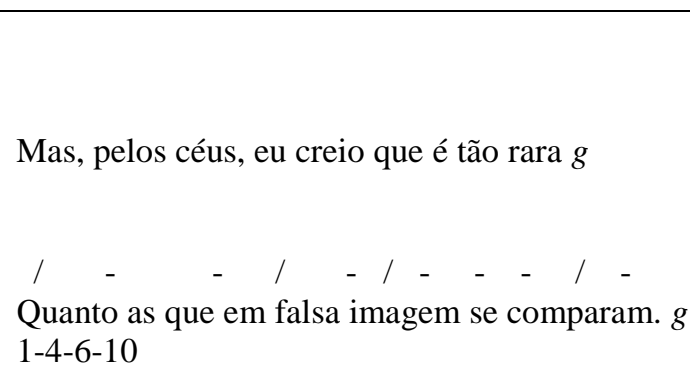 \\
\hline $\begin{array}{l}\text { Sem alteração semântica: } \\
\text { And yet, by heaven, I think my love as rare } g\end{array}$ & Mas, pelos céus, eu creio que é tão rara $g$ \\
\hline
\end{tabular}

${ }^{24}$ A rima entre rara/comparam se enquandra no mesmo tipo de rima abreviada já mencionada neste subcapítulo, entre esplende/ desprendem. 
-||$--|-/|-1|-1|$ As any she belied with false compare. J-P-J-J-J
I - - 1 - 1 - - - I-

Quanto as que em falsa imagem se compara. $g$

$1-4-6-10$

\section{5}

\section{Resultados L}

\subsection{1}

\section{Estudo de caso 2: gabarito do nível formal}

\begin{tabular}{|c|c|}
\hline $\begin{array}{l}-\quad /|-\quad /|-\quad /|-/|-\quad / \mid \\
\text { My mistress' eyes are nothing like the sun; } a \text { J-J-J- } \\
\text { J-J }\end{array}$ & $\begin{array}{l}-/-\quad / \quad l /-\quad-\quad I /- \\
\text { O seu olhar não é o de um sol puro; } a \\
\text { 2-4-(5)-6- (9)-10 }\end{array}$ \\
\hline $\begin{array}{l}/-|-/|-/|--| / /|| \\
\text { Coral is far more red than her lips' red; } b \text { T-J-J-P-E }\end{array}$ & $\begin{array}{l}-/ \quad-/-/-\quad-\quad-\quad / \\
\text { Nenhum coral os lábios lhe acendeu; } b \text { 2-4-6- } \\
10\end{array}$ \\
\hline 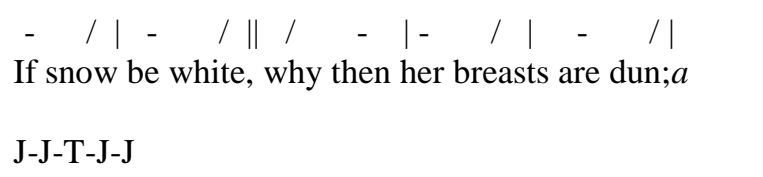 & $\begin{array}{l}-\quad / \quad / \quad /-\quad /-/-/- \\
\text { Se a neve é branca, os seios tem escuros; } a \\
\text { 2-(3)-4-6-8-10 }\end{array}$ \\
\hline $\begin{array}{l}-\quad||-\quad / \||/ \quad /||/ \quad-|-|/| \\
\text { If hairs be wires, black wires grow on her head. } b \text { J- } \\
\text { J-E-T-J }\end{array}$ & $\begin{array}{l}-\quad / \quad|-\quad-\quad-\| / \quad| \quad / \\
\text { Se são fio os cabelos, negro é o seu. } b \\
\text { 2-(3)-6-8 -(9)-10 }\end{array}$ \\
\hline
\end{tabular}




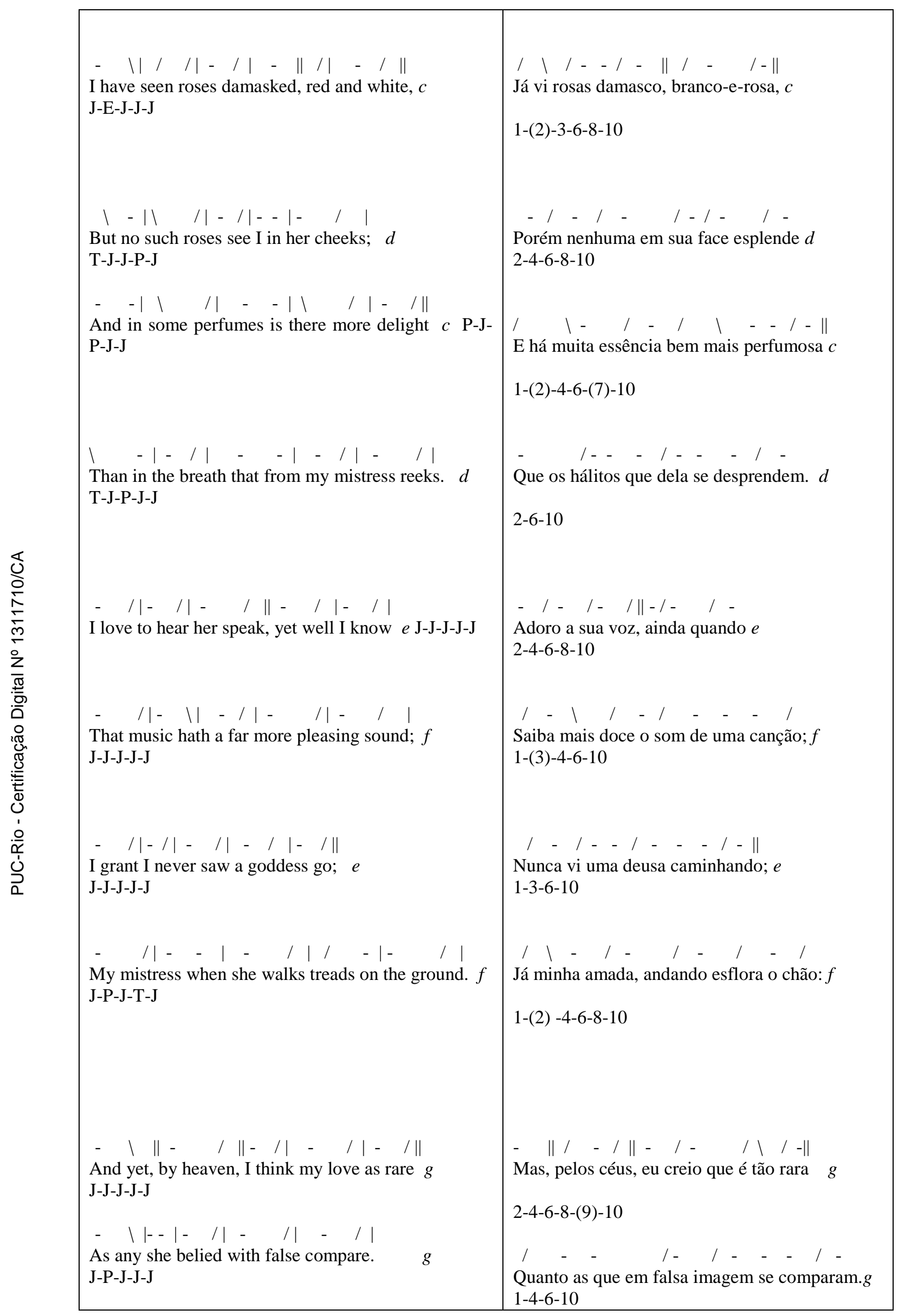




\section{5 .2}

\section{Aspectos do nível formal}

O original, que é um soneto composto por três quartetos e um dístico final, totalizando 14 versos, é traduzido em um poema com essa exata estrutura. O contrato métrico do original é o pentâmetro jâmbico, apresentando muitas variações. O primeiro verso é um pentâmetro jâmbico perfeito, que só volta aparecer na segunda metade do poema: no nono, décimo, décimo primeiro e décimo terceiro verso. Na tradução, o contrato métrico é o heroico. Os únicos versos que são desviantes do contrato são o primeiro da segunda estrofe e o terceiro da terceira estrofe - martelos-agalopados. Assim, podemos dizer que a tradução apresenta uma estrutura métrica mais regular que o original.

Quanto às rimas, o tradutor reproduz o mesmo esquema de rimas do original. No entanto, encontramos na tradução rimas incompletas: $a$ (toante), entre "puros" e "escuros"; $d$ (abreviada), entre "esplende" e "desprendem"; e $g$ (abreviada), entre "rara" e "comparam"; enquanto, no original, todas as rimas são completas.

\section{5 .3}

\section{Articulação de aspectos do nível formal com o nível semântico-lexical}

Ao longo do soneto, o eu-lírico apresenta sua amada através de comparações inusitadas, em sua maioria, com elementos da natureza. Em alguns casos, tais comparações são marcadas por pausas, tanto no original quanto na tradução:

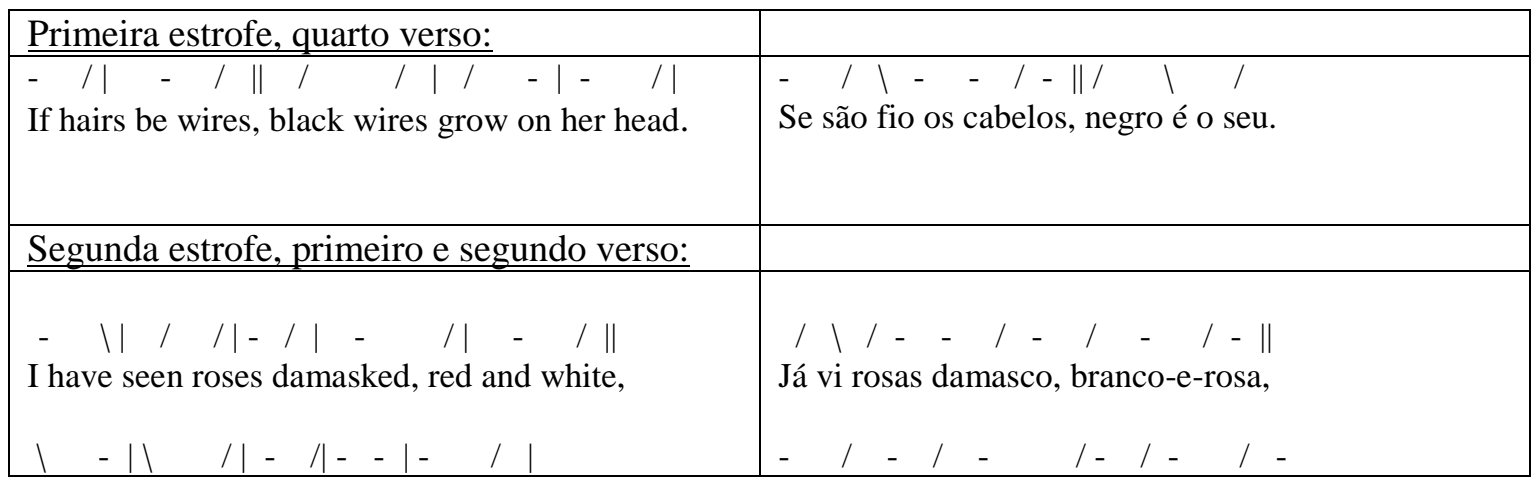




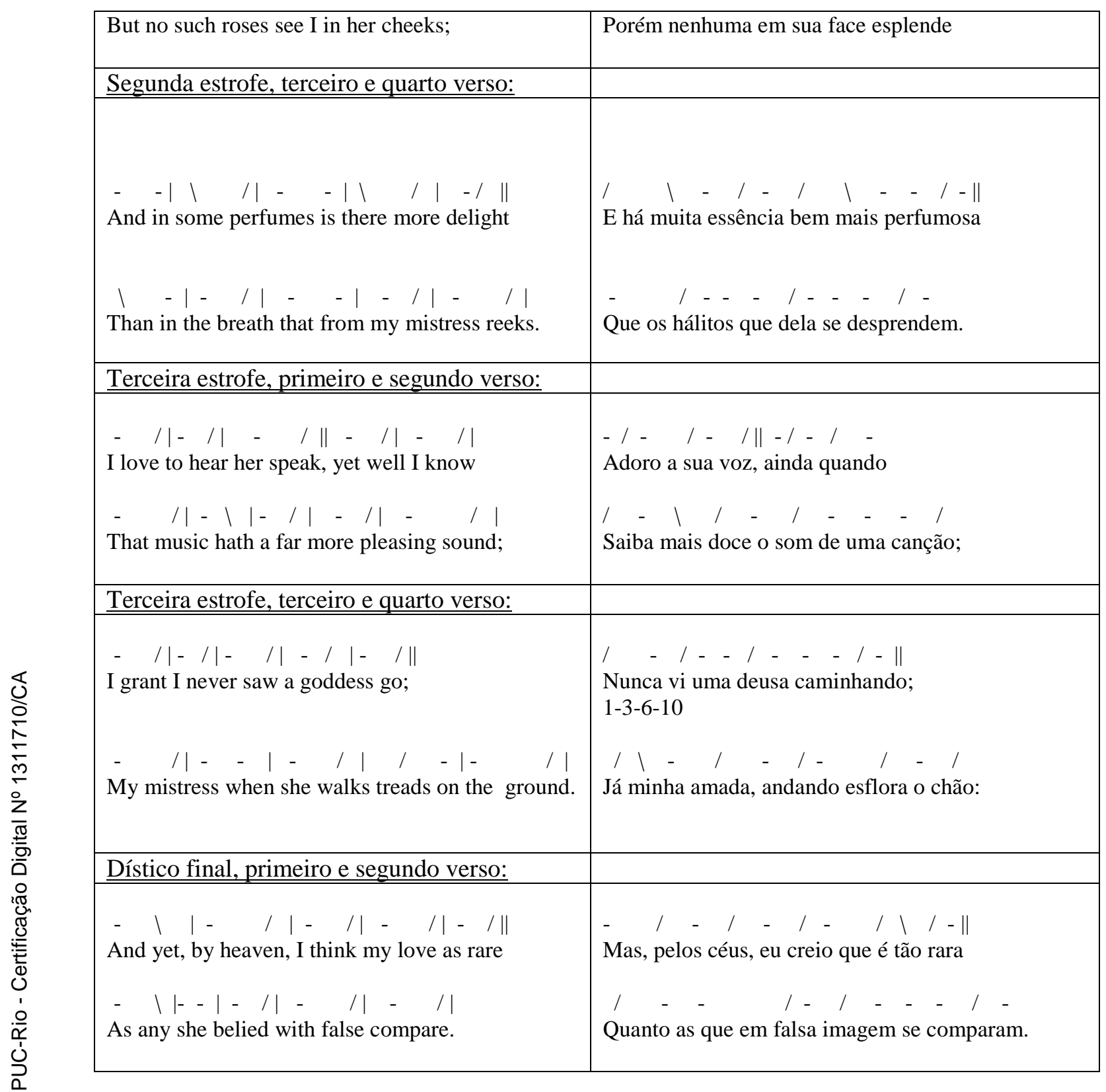

Há um caso em que somente no original a comparação é marcada com pausa:

\begin{tabular}{|l|}
\hline Primeira estrofe, terceiro verso:nesse caso, \\
a tradução reproduziu a comparação, \\
porém, como ocorre elisão entre a vogal \\
final de "branca" e a vogal inicial de "os", \\
não há pausa no verso em português. \\
\hline$\quad / \quad-\quad / \| / \quad-\quad|-\quad / \quad|-/ /$ \\
If snow be white, why then her breasts are dun;
\end{tabular}


Em alguns casos, a pausa, no original, não é utilizada para marcar comparações, e não tem qualquer relação com o plano semântico. Nos casos a seguir, as pausas são reproduzidas na tradução:

\begin{tabular}{|c|c|}
\hline Segunda estrofe, primeiro verso: & \\
\hline $\begin{array}{c}-|| / /|-||-\| /|-\quad /|| \\
\text { I have seen roses damasked, red and white, }\end{array}$ & 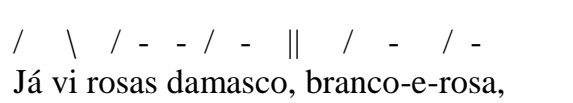 \\
\hline Dístico final, primeiro verso: & \\
\hline $\begin{array}{c}\quad \backslash\|-\quad|\|-\quad /|-||-|| \mid \\
\text { And yet, by heaven, I think my love as rare }\end{array}$ & $\begin{array}{l}-\|/ \quad-\quad /\|-\quad /-\quad / \quad \backslash / \text { - } \\
\text { Mas, pelos céus, eu creio que é tão rara }\end{array}$ \\
\hline
\end{tabular}

\section{6}

\section{Resultados M}

\subsection{1}

\section{Estudo de caso 2: gabarito do plano de recursos sonoros}

\begin{tabular}{|c|c|}
\hline $\begin{array}{r}\left.\{\mathrm{M}\}^{\text {ali }}\{\mathrm{y}\}^{\text {asson }}\{\mathrm{m}\}^{\text {ali istress' }} \text { ieye }\right\}^{\text {asson }} \text { s are } \\
\quad\left[\text { nothing }\{1\}^{\text {ali }}\{\mathrm{i}\}^{\text {asson }} \text { ke the sun; }\right.\end{array}$ & $\begin{array}{r}\mathrm{O}\{\mathrm{s}\}^{\text {ali }}\{\mathrm{eu}\}^{\mathrm{ri}} \text { olhar não é o de um }\{\mathrm{s}\}^{\text {ali }} \text { ol } \\
\text { [puro; }\end{array}$ \\
\hline $\begin{array}{l}\operatorname{Co}\{r\}^{\text {ali }} \text { al is fa }\{r\}^{\text {ali }} \operatorname{mo}\{r\}^{\text {ali }} \text { e }\left\{\{r\}^{\text {ali }} \text { ed }\right\}^{\text {repd }} \\
\quad\left[\text { than he }\{r\}^{\text {ali }}\{1\}^{\text {ali }} \text { ips' }\left\{\{r\}^{\text {ali }}\{e\}^{\text {asson }} d\right\}^{\text {repd }}\right.\end{array}$ & $\begin{array}{r}\text { Nenhum } \operatorname{cor}\{a\}{ }^{\text {asson }} 1 \text { os } 1\{\text { á }\}{ }^{\text {asson }} \text { bios lhe } \\
\text { [acend }\{\mathrm{eu}\}^{\mathrm{ri}} \text {; }\end{array}$ \\
\hline $\begin{array}{l}\text { If snow be }\{\text { whi }\}^{\text {repd }} \text { te, }\{\text { why }\}^{\text {repd }} \text { then he }\{r\}^{\text {ali }} \\
\qquad\left[\mathrm{b}\{r\}^{\text {ali }}\{\mathrm{e}\}^{\text {asson }} \text { sts } a\{r\}^{\text {ali }} \text { e dun; }\right.\end{array}$ & $\begin{array}{l}\left\{\{S\}^{\text {ali }}\right\}^{\text {repd a } n\{e\}^{\text {asson }} \text { ve }\{e ́\}^{\text {asson }} \text { branca, os }} \\
\quad\left[\{\mathrm{s}\}^{\text {ali }}\{\mathrm{e}\}^{\text {asson }} \text { ios } \mathrm{t}\{\mathrm{e}\}^{\text {asson }} \mathrm{m}\{\mathrm{e}\}^{\text {asson }} \text { scuros; }\right.\end{array}$ \\
\hline $\begin{array}{l}\text { If }\{\mathrm{h}\}^{\text {ali }}\{\text { ai }\}^{\text {asson }}\{r\}^{\text {ali }} \text { s be }\left\{\text { wi }\{r\}^{\text {ali }} \text { es }\right\}^{\text {repd }}, \\
{\left[\text { black }\left\{w i\{r\}^{\text {ali }} e s\right\}^{\text {repd }} g\{r\}^{\text {ali }} \text { ow on }\right.} \\
{\left[\{h\}^{\text {ali }} e\{r\}^{\text {ali }}\{h\}^{\text {ali }}\{\text { ea }\}^{\text {asson }} \text { d. }\right.}\end{array}$ & 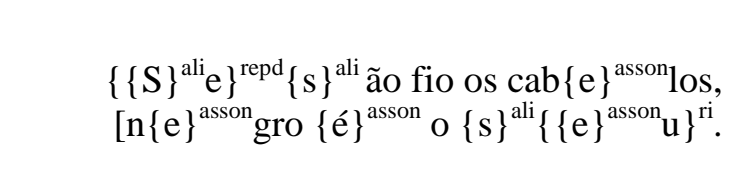 \\
\hline $\begin{array}{l}\text { I have seen }\left\{\{r\}^{\text {ali }}{ }^{\text {oses }}\right\}^{\text {repd }} \text { damasked, } \\
\qquad\{r\}^{\text {ali }} \text { ed and white, }\end{array}$ & 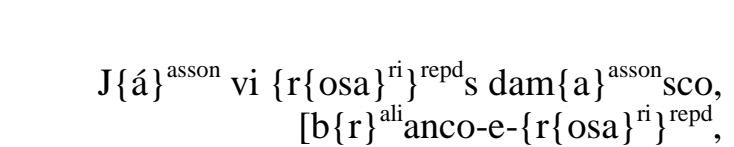 \\
\hline
\end{tabular}




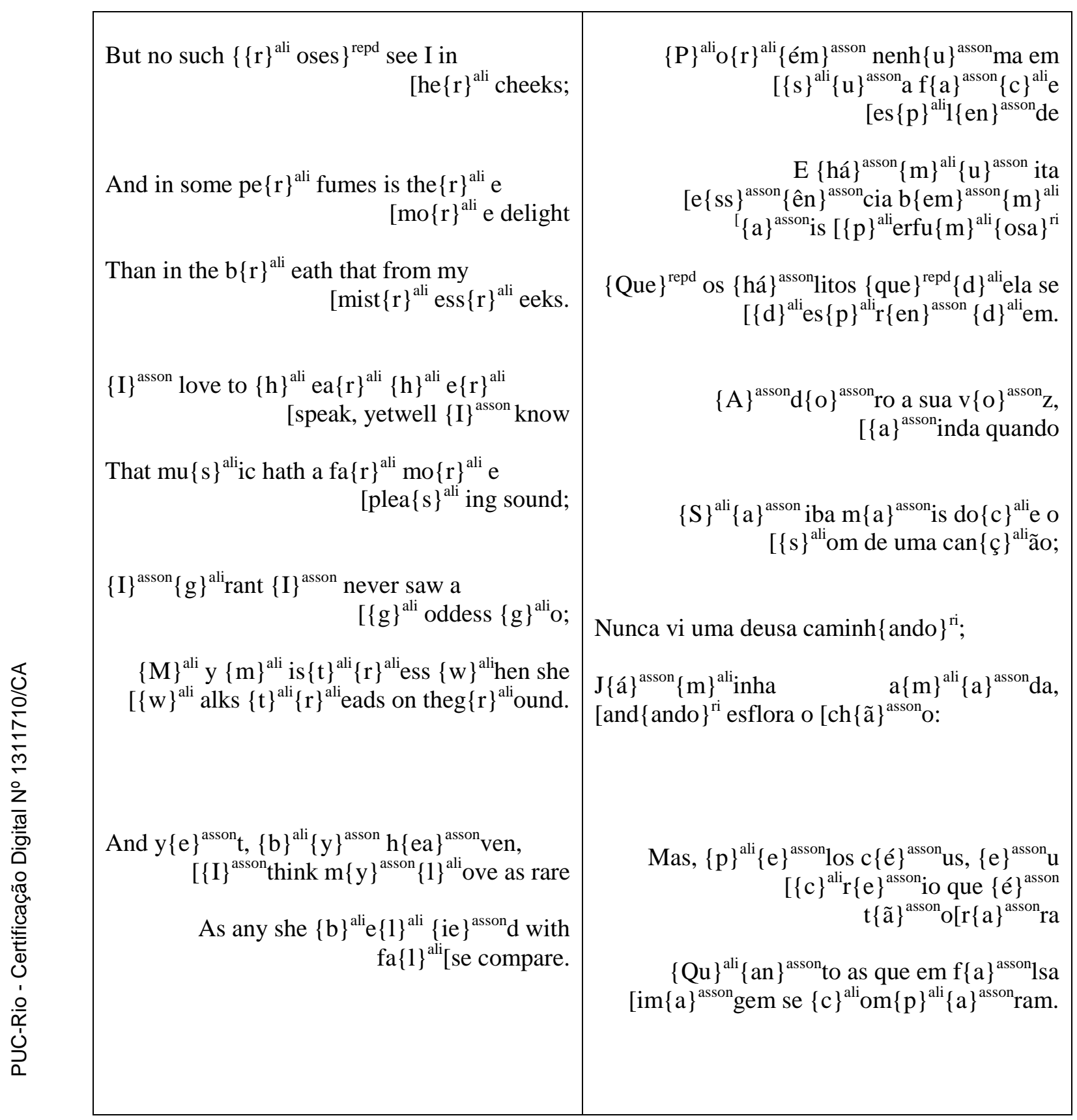

\subsection{2}

\section{Possíveis relações entre o plano de recursos sonoros e as categorias do nível semântico-lexical, com base nos Resultados $\mathrm{J}$}

Estratégias tradutórias que também não priorizam a reprodução de características fonológicas do original: 


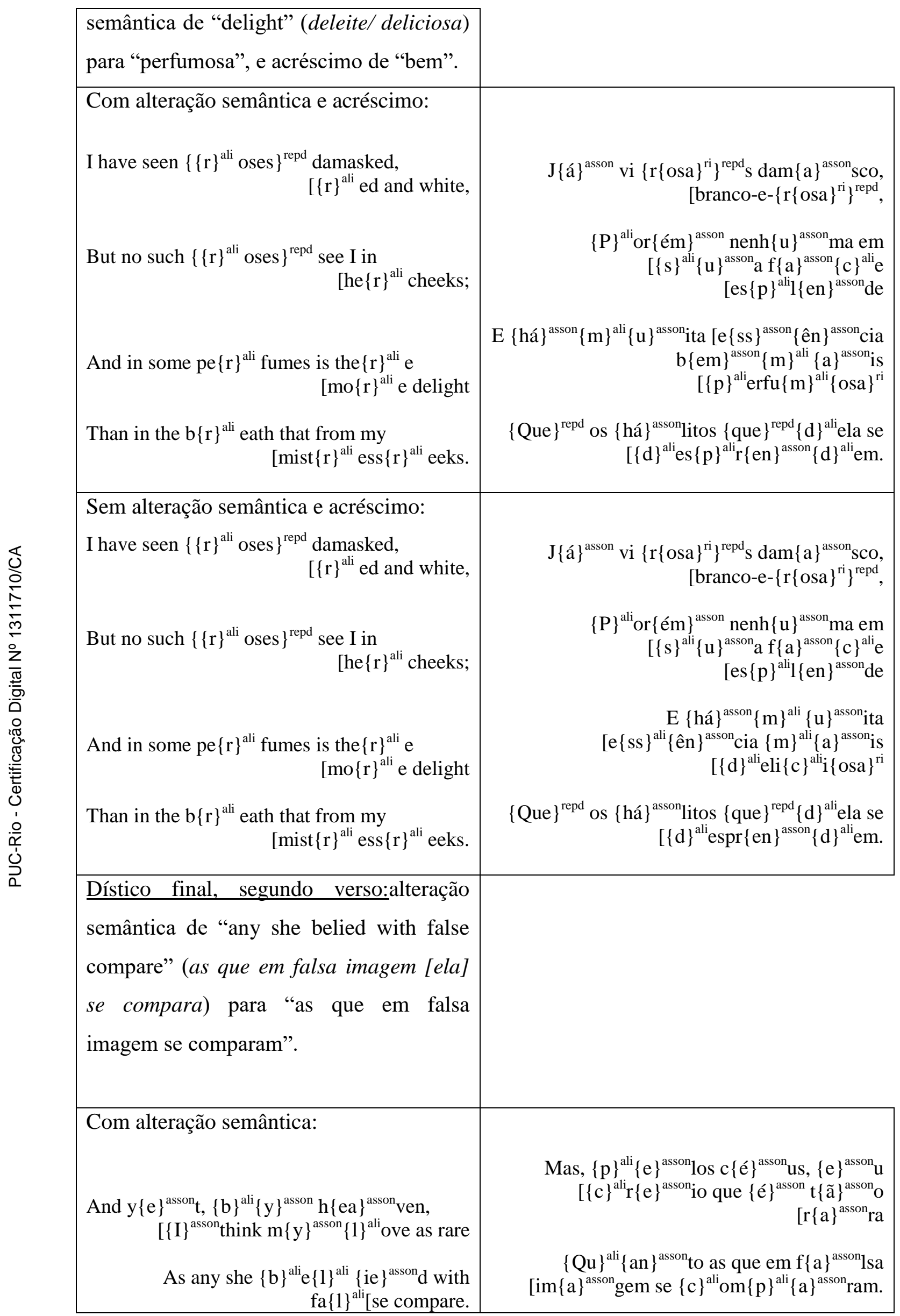




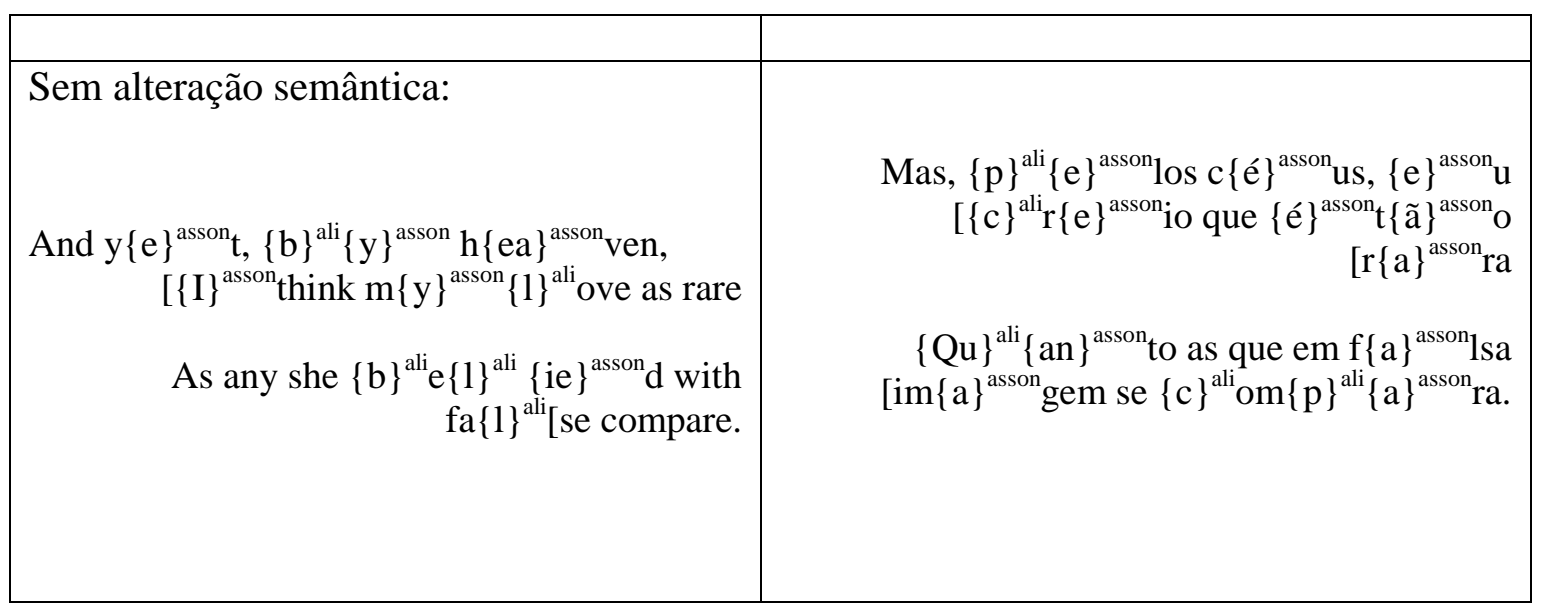

No primeiro caso (segunda estrofe, terceiro verso), temos, no original, aliteração (entre o segundo, terceiro e quarto verso da segunda estrofe) em /s/ (some, such); /r/ (perfumes, more, there, roses, her, reeks, breath, mistress, from); /ð/ (there, Than, that); e assonância em /ai/ (delight, $I, m y)$. Na tradução encontramos uma variedade maior de recursos sonoros, tais como aliterações em /m/ (muita, mais, perfumosa);/p/(porém, esplende, perfumosa, desprendem); /s/ (sua, face, essência); assonâncias em /a/ (face, há, mais); /u/ (nenhuma, sua, muita); /eN/ (porém, essência , esplende, bem, desprendem); e rima interna em "osa" (rosa, perfumosa).Mesmo sem a alteração semântica e sem o acréscimo, teríamos a mesma variedade de recursos sonoros: aliteração em /m/ (muita, mais); /d/ (deliciosa, dela, desprendem); /s/ (sua, face, essência, deliciosa); assonâncias em /a/ (face, há, mais); /u/ (nenhuma, sua, muita); /eN/ (porém, essência, esplende, desprendem); e rima interna em "osa" (rosa, deliciosa): três aliterações, três assonâncias e uma rima interna.

No segundo caso (dístico final, segundo verso), temos aliteração em /b/ : by, belied e /1/: love, belied, false; assonância em /aI/: by, I, my, belied.A tradução apresenta uma diversidade maior de recursos sonoros, tais como aliteração em /k/ (creio, quanto, comparam); e /p/ (pelos, comparam); assonância em /aN/ (quanto/ tão); e /a/ (falsa, imagem, comparam, rara). Mesmo sem a alteração semântica, notaríamos essa mesma diversidade de recursos sonoros: /k/ (creio, quanto, compara); e /p/ (pelos, compara); assonância em /aN/ (quanto/ tão); e /a/ (falsa, imagem, compara, rara): duas aliterações e duas assonâncias. 


\section{6 .3}

\section{Articulação de aspectos do plano de recursos sonoros com o nível semântico-lexical}

Tanto no original quanto na tradução encontramos variadas aliterações, assonâncias e repetições diversas. No poema em português encontramos, também, rimas internas. Destaco, a seguir, alguns recursos sonoros que enfatizam determinados sentidos do original, e que são reproduzidos na tradução, também através de recursos sonoros:

\begin{tabular}{|l|r|}
\hline $\begin{array}{r}\text { I have seen }\left\{\{r\}^{\text {ali }} \text { oses }\right\}^{\text {repd }} \text { damasked, } \\
{\left[\{r\}^{\text {ali }} \text { ed and white, }\right.}\end{array}$ & Já vi $\{\text { rosa }\}^{\text {repd }}$ damasco, branco-e- \\
{$\left[\{\text { rosa }\}^{\text {repd }}\right.$,}
\end{tabular}

No primeiro e segundo verso da segunda estrofe, observamos, no original, aliteração em /r/ (roses, red, her) e repetição diversa de "roses". Ambos os recursos podem ter sido utilizados para enfatizar a noção da cor avermelhada, rubra (red) das rosas (roses), ao compará-las com a face da amada. Na tradução, notamosrepetição diversa de "rosa", utilizada, acredito, para tentar manter o efeito que recursos semelhantes causam no original.

Em alguns casos, a tradução não reproduz os efeitos causados por recursos sonoros no original, ao utilizar, também, esses tipos de recursos:

$$
\begin{gathered}
\operatorname{Co}\{r\}^{\text {ali }} \text { al is fa }\{r\}^{\text {ali }} \operatorname{mo}\{r\}^{\text {ali }} \text { e }\left\{\{r\}^{\text {ali }} \text { ed }\right\}^{\text {repd }} \\
{\left[\text { than he }\{r\}^{\text {ali }} \text { lips }\left\{\{r\}^{\text {ali }} \text { ed }\right\}^{\text {repd }}\right.}
\end{gathered}
$$

Nenhum cor $\{a\}^{\text {asson }} 1$ os $1\{a ́ \text { á }\}^{\text {asson }}$ bios lhe [acendeu

No segundo verso da primeira estrofe, observamos, no original, aliteração em $/ \mathrm{r}$ / (Coral, far, more, red, her) e repetição diversa de "red". Ambos os recursos podem ter sido utilizados para enfatizar a noção da cor vemelha, rubra (red) do coral, ao comparálo com os lábios da amada. Na tradução, notamos assonância em /a/ (coral, lábios), que 
considero como um recurso puramente sonoro aqui, sem qualquer relação com o plano do sentido do original.

If $\{h\}^{\text {ali }}\{\text { ai }\}^{\text {asson }}\{r\}^{\text {ali }}$ s be $\left\{w i\{r\}^{\text {ali }} e s\right\}^{\text {repd }}$,

[black $\left\{w i\{r\}^{\text {ali }} e s\right\}^{\text {repd }} \mathrm{g}\{r\}^{\text {ali }}$ ow on $\left[\{\mathrm{h}\}^{\text {ali }} \mathrm{e}\{\mathrm{r}\}^{\text {ali }}\{\mathrm{h}\}^{\text {ali }}\{\mathrm{ea}\}^{\text {asson }} \mathrm{d}\right.$.

Se são fio os cab $\{e\}^{\text {asson }}$ los, $n\{e\}^{\text {asson }}$ gro é o $\left[\mathrm{s}\{\mathrm{e}\}{ }^{\text {asson }} \mathrm{u}\right.$.

No quarto verso da primeira estrofe, notamos, no original, aliterações em $/ \mathrm{h} /$ (hairs, her, head), e /r/ (hairs, wires, grow, her); assonância em /E/ (hairs, head); e repetição diversa de "wires". Creio que tais recursos foram utilizados para enfatizar a comparação dos cabelos da amada (hairs, sons de /h/, /r/ e / / $/$ ) com fios de arames (wires). Na tradução, observamos assonância em /e/ (negro, seu, cabelos), que pode ter sido utilizada para destacar a ideia de que os cabelos da amada são negros. No entanto, esse recurso não é usado para enfatizar a comparação. 


\section{Resultados da terceira etapa}

\section{1}

\section{Tabela GJ : comparação dos resultados G e J}

\begin{tabular}{|c|c|}
\hline \multicolumn{2}{|c|}{$\begin{array}{l}\text { Número de ocorrências de estratégias tradutórias que aparentemente priorizam } \\
\text { reproduzir aspectos formais do original }\end{array}$} \\
\hline Ivo Barroso & 11 \\
\hline Jorge Wanderley & 10 \\
\hline \multicolumn{2}{|c|}{$\begin{array}{l}\text { Número de ocorrências de estratégias tradutórias que aparentemente não priorizam } \\
\text { reproduzir aspectos formais do original }\end{array}$} \\
\hline Ivo Barroso & 1 \\
\hline Jorge Wanderley & 3 \\
\hline
\end{tabular}

A tradução de Barroso apresenta 12 ocorrências de estratégias tradutórias no total. Dessas 12, uma parece não priorizar a manutenção de características formais do original.

A tradução de Wanderley apresenta 13 ocorrências de estratégias tradutórias no total. Dessas 13, três parecem não tentar manter aspectos formais do original.

\section{2}

Tabela HL: comparação dos resultados H e L

\begin{tabular}{|l|l|}
\hline \multicolumn{2}{|c|}{ Reprodução ou não da forma poética do original: soneto } \\
\hline Ivo Barroso & Sim \\
\hline Jorge Wanderley & Sim \\
\hline & Número de rimas incompletas \\
\hline Ivo Barroso & 1 \\
\hline
\end{tabular}




\begin{tabular}{|c|c|}
\hline Jorge Wanderley & 3 \\
\hline \multicolumn{2}{|c|}{$\begin{array}{l}\text { Número de casos em que o tradutor prioriza reproduzir aspectos formais do } \\
\text { original que se articulam de modo evidente com o nível semântico-lexical }\end{array}$} \\
\hline Ivo Barroso & 6 \\
\hline Jorge Wanderley & 6 \\
\hline \multicolumn{2}{|c|}{$\begin{array}{l}\text { Número de casos em que o tradutor não prioriza reproduzir aspectos formais do } \\
\text { original que se articulam de modo evidente com o nível semântico-lexical }\end{array}$} \\
\hline Ivo Barroso & 1 \\
\hline Jorge Wanderley & 1 \\
\hline
\end{tabular}

Quanto aos dois primeiros itens, notamos que tanto uma tradução quanto a outra foram escritas em forma de soneto; e que Wanderley formou mais rimas incompletas que Barroso.

Em relação aos dois últimos quesitos, observamos que o número de casos é o mesmo em ambas.

\section{3}

\section{Tabela IM: comparação dos resultados I e M}

\begin{tabular}{|l|l|}
\hline \multicolumn{2}{|c|}{$\begin{array}{c}\text { Número de ocorrências de estratégias tradutórias que aparentemente também não } \\
\text { priorizam reproduzir aspectos fonológicos do original }\end{array}$} \\
\hline Ivo Barroso & 1 \\
\hline Jorge Wanderley & 3 \\
\hline $\begin{array}{c}\text { Número de casos em que o tradutor prioriza reproduzir aspectos fonológicos do original } \\
\text { que se articulam de modo evidente com o nível semântico-lexical }\end{array}$ \\
\hline Ivo Barroso & 2 \\
\hline Jorge Wanderley & 1 \\
\hline Número de casos em que o tradutor não prioriza reproduzir aspectos fonológicos do \\
original que se articulam de modo evidente com o nível semântico-lexical \\
\hline Ivo Barroso & 1 \\
\hline Jorge Wanderley & 2 \\
\hline
\end{tabular}


O número de ocorrências de estratégias tradutórias refere-se àquelasjá demonstradas neste capítulo, subcapítulo Tabela GJ: comparação dos resultados G e J, em "Número de ocorrências de estratégias tradutórias que aparentemente não priorizam reproduzir aspectos formais do original". Essas ocorrências, tanto em uma tradução quanto na outra, não se justificam em termos formais e nem em termos fonológicos.

A tradução de Barroso apresenta dois casos de manutenção de características fonológicas do original que se articulam de modo evidente com o nível semânticolexical, e um caso de não manutenção.

A tradução de Wanderley apresenta um caso de reprodução de aspectos fonológicos do original que mantêm relação observável com o nível semântico-lexical, e dois casos de não reprodução.

\section{4}

\section{Discussão dos resultados}

De acordo com a tabela HL, observamos que houve manutenção da forma do originalem ambas as traduções: cada poema traduzido é um soneto composto por três quartetos e um dístico final, somando 14 versos. Quanto às rimas, todas do poema original são completas. Considero que, nesse caso, qualquer rima incompleta na tradução já implicaria perda. De acordo com a tabela em questão, Wanderley forma mais rimas incompletas que Barroso. Assim, sob essas condições, a tradução de Barroso apresenta perdas menores.

Considero que o uso de qualquer uma das estratégias tradutórias discutidas nesta tese - alteração semântica, omissão, acréscimo - implicará, necessariamente, uma perda na tradução. Creio que aquelas que parecem ter sido utilizadas como tentativa de manter características formais ou fonológicas do original implicam perdas menores, quando comparadas com aquelas que, aparentemente, não tentam reproduzir tais aspectos do poema-fonte. Assim, de acordo com as tabelas GJ e IM, podemos dizer que, nesses quesitos, a tradução de Barroso apresenta perdas menores.

Também considero que a tradução deve priorizar reproduzir as características formais e fonológicas do original que mantêm uma relação notável com o plano do sentido. Creio que aquela que o faz apresenta maiores correspondências com o original, quando comparada com aquela que não prioriza tal manutenção. Assim, de acordo com 
as tabelas HL e IM, podemos dizer que, sob essas condições, a tradução de Barroso apresenta maiores correspondências.

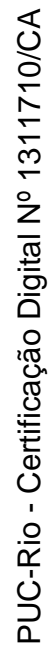




\section{Considerações finais}

A presente tese se inseriu no viés pós-estruturalista não radical, e teve como um dos objetivos fornecer, aos interessados em tradução de poesia, insumos para se poder avaliar, de modo minimamente consensual, traduções de poesia. Para isso, busquei explicitar, sistematizar e validar categorias do nível semântico-lexical, e descrever e confirmar categorias do nível formal e do plano de recursos sonoros, para poderem ser usadas na fundamentação de avaliações de traduções de poemas. Busquei validar e confirmar as categorias através da anotação, atividade que peguei emprestada da Linguística Computacional.

O estudo consistiu de três etapas. Na primeira, utilizei a anotação como metodologia na busca pelo consenso. Na segunda, foi utilizada a metodologia de Britto (2002; 2006c), com algumas observações adicionais, a fim de analisar os resultados da primeira etapa. E na terceira, os resultados da segunda etapa foram utilizados a fim de se gerarrecursos para uma possível avaliação entre duas traduções do soneto 130 de Shakespeare. Na primeira etapa, cheguei a algumas conclusões já esperadas: as categorias do nível formal e do plano de recursos sonoros foram as que permitiram mais consenso nos resultados obtidos através da comparação das anotações, e as do nível semântico-lexical, menos consenso. Isso talvez tenha acontecido porque as categorias do nível formal - PÉS, SÍLABAS, RIMAS, SÍMBOLOS PARA ESCANSÃO - e as do plano de recursos sonoros - ALITERAÇÕES, ASSONÂNCIAS, RIMAS INTERNAS, REPETIÇÕES DIVERSAS - podem ser identificadas e classificadas através do conhecimento convencionado de versificação. Como os anotadores tinham conhecimento sobre a versificação inglesa e portuguesa, o consenso não foi tão difícil de ser alcançado. Já as categorias do nível semântico-lexical - OMISSÃO, ACRÉSCIMO, ALTERAÇÃO SEMÂNTICA - trabalham no plano do sentido. Os significados variaram de acordo com as diferentes leituras, acerca das explicações das categorias e dos sentidos dos poemas, de cada anotador, resultando, assim, em menos 
convergências. Os resultados da segunda etapa - esta que evidencia, nos estudos de caso, a relação entre os níveis formal e semântico-lexical, e o plano de recursos sonoros - permitiram-me produzir elementos para uma possível avaliação:entre a tradução de Barroso e a de Wanderley, verificar qual seria a mais fiel ao original.

A descrição e confirmação das categorias do nível formal e do plano de recursos sonoros foram bem menos complexas do que a explicitação, sistematização e validação das categorias do nível semântico-lexical. A anotação de aspectos estruturantes e fonológicos de poemas é bastante comum entre estudiosos de poesia, mesmo sem eles se darem conta de que, ao adicionarem informações interpretativas sobre esses aspectos aos poemas, eles estão fazendo anotação. Assim sendo, tais categorias já vêm sendo validadas e usadas há tempos, e sua explicitação e sistematização estão presentes em obras antigas que tratam de verificação inglesa e portuguesa. Já as categorias do nível semântico-lexical foram criadas por Britto. Antes desse estudo, elas eram usadas somente por Britto e eu. Dessa forma, elas precisariam ser muito bem explicitadas e sistematizadas por mim, para que outros interessados em poesia pudessem validá-las e usá-las. A validação dessas categorias também não é nada simples.

A validação de categorias é obtida a partir da concordância observada através dacomparação de anotações feitas por diferentes estudiosos. Quanto às categorias do nível formal e do plano de recursos sonoros, sua sistematização, explicitação e validação já vêm correndo ao longo dos tempos. Eu as descrevi nesta tese baseando-me em obras de versificação, e sua validação foi, na verdade, uma confirmação de que seu uso permite que diferentes estudiosos observem as mesmas características significativas, em relação a um mesmo poema. Quanto ao nível formal, por mais que haja algumas discordâncias - em relação à distribuição de acentos nos versos, por exemplo - pude notar, em ambos os estudos de caso, que a tradução dos pentâmetros jâmbicos do original foi feita através de versos que tendem a padrões regulares de acentuação para os decassílabos, e que o esquema de rimas do original foi mantido na íntegra.E, quanto ao plano de recursos sonoros, mesmo havendo algumas divergências quanto à anotação de aspectos fonológicos - um anotador deixou de anotar um aspecto que outro anotou, por exemplo - a comparação das anotações permitiu que eu notasse que, tanto em um estudo de caso quanto no outro, os recursos sonoros não têm função estruturante, ocorrendo de modo irregular ao longo dos poemas. As convergências observadas através da comparação das anotações do nível formal e do plano de recursos sonoros já eram esperadas. 
Quanto às categorias do nível semântico-lexical, sua explicitação, sistematização e validação iniciaram-se nesta pesquisa, e podem continuar em estudos futuros. De um modo geral, a categoria que possibilitou mais convergências entre os anotadores foi ACRÉSCIMO, seguida de OMISSÃO e, por último, ALTERAÇÃO SEMÂNTICA. Acredito ser mais fácil obter consenso quando tratamos de categorias cujas explicações incluem adição ou retirada de elementos semânticos - apresentam uma contraparte formal - tais como as duas primeiras. Já quanto à última, como suas explicações são baseadas exclusivamente na modificação de sentido, convergências são mais difíceis de ocorrer. De todo modo, todas as três categorias apresentaram discordâncias, o que evidencia a instabilidade dessas categorias, que nada mais são que palavras da linguagem natural. Através dos resultados A1, A2 e D, pude notar como nossas idealizações são limitadas. Para identificar e classificar as categorias em questão, cujas explicações e reformulações parecem óbvias, aderimos a uma série de pressupostos, não explicitados, que permeiam nosso entendimento do que viria a ser uma omissão, um acréscimo, uma alteração semântica. A anotação nos obriga a delimitar as explicações das categorias, para que se chegue cada vez mais perto do consenso.

Ainda sobre as categorias OMISSÃO, ACRÉSCIMO e ALTERAÇÃO SEMÂNTICA, a fim de conseguir cada vez mais consenso a partir dos resultados A1, A2 e D, fui refinando as categorias, incluindo cada vez mais limites e exceções. Tal estratégia, em vez de possibilitar mais concordância, acabou levando a mais discordâncias. Notei que, por mais que eu delimitasse tais categorias, cada anotador tem uma visão acerca do que seria omissão, acréscimo e alteração de elementos semânticos, o que dificulta a ocorrência de concordâncias. Apesar das discordâncias cada vez mais numerosas, observei que, ao tornar as categorias mais e mais granulares, pude montar o gabarito do nível semântico-lexical dos estudos de caso com as categorias SL4 e, assim, verificar mais minuciosamente se algumas delas foram utilizadas para reproduzir aspectos estruturantes ou fonológicos do original.

As divergências no nível semântico-lexical, salientadas pela anotação, não são encaradas de modo absoluto: como não há total concordância, apenas pode haver total discordância e, assim, não há como existir avaliações de tradução de poesia com um mínimo de consenso. Neste estudo, consideramos que as categorias utilizadas, apesar de imprecisas, podem apontar novos caminhos que nos aproximem cada vez mais de uma metodologia para avaliações cada vez mais concordantes. 
A pesquisa apresenta três produtos concretos: os guias F, RS e SL4, este último composto por categorias que sofreram três reformulações cada. Esses guias podem ser considerados os insumos que me propus a fornecer aos interessados em avaliações de tradução de poesia. Meu desejo de aperfeiçoar os guias, a partir do recuo no grau de especificidade das categorias, por exemplo, e da descrição de outras categorias relacionadas ao nível formal e ao plano de recursos sonoros, pode abrir portas para estudos futuros. Uma questão que eu poderia incluir nesse aprimoramento seria aquela da correspondência formal e funcional, muito importante na tradução de alguns poetas, como Dickinson. Os resultados da terceira etapa também podem ser considerados insumos, elementos, recursos para possíveis avaliações minimamente consensuais de traduções específicas: aquela de Barroso e a de Wanderley.

A hipótese foi comprovada quanto ao nível formal e ao plano de recursos sonoros, mas não quanto ao nível semântico-lexical. As categorias do nível formal e do plano de recursos sonoros foram confirmadas, o que pode permitir consenso entre avaliações desse nível e plano. Já quanto ao nível semântico-lexical, a hipótese ainda pode ser comprovada, pois a validação de suas categorias pode prosseguir em pesquisas futuras, o que pode ou não resultar na possibilidade de concordância entre avaliações desse nível.

Acredito que tal pesquisa pode ser considerada como uma das possíveis continuações do pontapé inicial dado por Britto na questão de avaliações minimamente consensuais de traduções de poesia. Creio que a área de tradução de poesia enriqueceuse do diálogo com a Linguística Computacional: a anotação prevê interpretações e tomadas de decisão, evidenciando, assim, as possíveis interpretações e decisões tomadas durante o processo de tradução.

Um caminho que poderia ser seguido a partir desta pesquisa, através de uma parceria com a Engenharia Computacional, seria o desenvolvimento de uma ferramenta para anotação de poemas, e de uma métrica para avaliação de traduções de poesia, utilizando as categorias presentes nesta tese. Assim, este estudo poderia ser visto, de certa forma, como uma contribuição para a Linguística Computacional também. 


\section{Referências bibliográficas}

ALPHABETIC INC. Google Translate.Mountain View, Califórnia: [s.n.], 2007. Disponível em: https://translate.google.com.br/m/translate. Acesso em: 09 fev. 2017.

ARROJO, Rosemary. Compreender $X$ interpretar e a questão da tradução. In: (Org).O signo desconstruído:implicações para a tradução, a leitura e o ensino. $2^{\underline{a}}$ ed. Campinas, SP: Pontes, 2003a.

2002. Oficina de tradução: a teoria na prática. 4. ed., São Paulo: Ática,

A que são fiéis tradutores e críticos de tradução? Paulo Vizioli e Nelson Ascher discutem John Donne. In: e psicanálise. Rio de Janeiro: Imago, 1993. Tradução, desconstrução

BEZERRA, Benedito G. Discurso religioso e tradução: uma análise crítica da tradução de termos relativos ao sacerdócio. Revista Brasileira de Linguistica Aplicada, Belo Horizonte, v.15, n¹, jan-mar, p. 237-259, 2015.

BRITTO, Paulo H.A tradução literária. Rio de Janeiro: Civilização Brasileira, 2012.

Para uma tipologia do verso livre em português e inglês. Revista Brasileira de Literatura Comparada, v. 19, p. 127-144, 2011.

Padrão e desvio no pentâmetro jâmbico inglês: um problema para a tradução. In: Guerini, Andréia et al. (org.). Literatura traduzida e literatura nacional. Rio de Janeiro: 7Letras, 2008 a.

. Correspondência formal e funcional em tradução poética.

In:Souza, Marcelo Paiva de et al. Sob o signo de Babel: literatura e poéticas da tradução. Vitória: PPGL/MEL / Flor\&Cultura, 2006c.

- Fidelidade em tradução poética: o caso Donne. Terceira Margem, Rio de Janeiro,v. X, no 15, jul-dez, p. 239-254, 2006b.

.Desconstruir para quê?. Cadernos de Tradução (UFSC), Florianópolis, v. 8, p. 41-50, 2003. 
Para uma avaliação mais objetiva das traduções de poesia. In:

KRAUSE, Gustavo Bernardo. As margens da tradução. Rio de Janeiro: FAPERJ/Caetés/UERJ, 2002.

CHOCIAY, R. Teoria do verso. São Paulo: McGraw-Hill do Brasil, 1974.

CRUZ e SOUSA,João. Violões que choram. In:

Poesias Completas de Cruz e Sousa. Rio de Janeiro: Ediouro, 1995, p.50-53.

DICKINSON, E. 96. In: AMARAL, A. L. (org.). Cem poemas. Tradução, posfácio e organização de Ana Luísa Amaral. Lisboa: Relógio d'água, 2010.

ELLIS, John M. The heart of language: categorization. In: Language, Thought and Logic. Evanston, IL: Northwestern University Press, 1993. p. 2744.

FARLEX, Inc. TheFreeDictionary.com. Huntingdon Valley, Pennsylvania: [s.n.], 2003. Disponível em: < http://www.thefreedictionary.com/ >. Acesso em: 09 fev. 2017.

FRASER, G.S. The Critical Idiom: Metre, Rhyme and Free Verse. London: Metheun \& Co., Ltd., 1977.

FREITAS, C. Corpus, Linguística Computacional e as Humanidades Digitais. In: LEITE, M.S; GABRIEL, C.T. (orgs.).Linguagem, Discurso, Pesquisa e Educação. Petrópolis: De Petrus; Rio de Janeiro: FAPERJ, 2015.

FUSSELL, Paul. Poetic Meter and Poetic Form. Revised Edition. New York: McGraw-Hill, 1979.

GATE Team. GATE Teamware User Guide.[S.I.: s.n.],2010. Disponível em: $<$ https://gate.ac.uk/family/coming-soon/teamware-1.2.2-guide.pdf>. Acesso em: 05 fev. 2017.

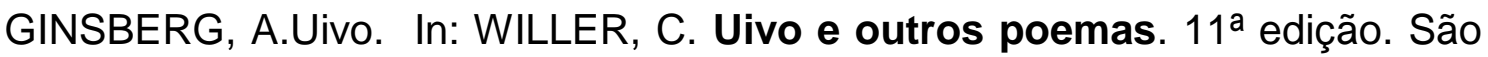
Paulo: LP\&M, 2010.

Lights Books, 1956.

Howl. In: Howl \& Other Poems. San Francisco:City

GOVE, Philip B. Webster's third new international dictionary of the English language. Springfield: Merriam-Webster, 2000.

GRIGOLETTO, Marisa. A desconstrução do signo e a ilusão da trama. In: ARROJO, R. (Org).O signo desconstruído:implicações para a tradução, a leitura e o ensino. $2^{\mathrm{a}}$ ed. Campinas, SP: Pontes, 2003a.

HOLLANDER, John. Rhyme's Reason: A Guide to English Verse. New Haven: Yale University Press, 1989. 
HOUSE, Juliane. A model for translation quality assessment. 2nd ed. Tubingen : Narr, 1981.

JORGE Wanderley. In: ENCICLOPÉDIA Itaú Cultural de Arte e Cultura Brasileiras. São Paulo: Itaú Cultural, 2017. Disponível em: $<$ http://enciclopedia.itaucultural.org.br/pessoa445980/jorge-wanderley>. Acesso em: 14 de Abr. 2017.

LARANJEIRA, Mário. Poética da tradução. São Paulo: EDUSP, 1993.

LEECH, G. Introducing corpus annotation. In: GARSIDE, R.; LEECH, G.; MCENERY, T. Corpus annotation: linguistic information from computer text corpora. London: Longman, 1997. p. 1-18.

LIRA, José. A invenção da rima na tradução de Emily Dickinson. Cadernos de Tradução, Santa Catarina, v. 2,nำ6, p. 77-103, 2000.

MATTOSO, Glauco. Tratado de versificação. São Paulo: Editora ANNABLUME, 2010.

MENEZES, Juliana Cunha; BRITTO, Paulo Fernando Henriques. Fernando Pessoa como tradutor. Rio de Janeiro, 2012. 111p. Dissertação de Mestrado - Departamento de Letras, Pontifícia Universidade Católica do Rio de Janeiro.

NIETZSCHE, F. Sobre verdade e mentira no sentido extra-moral. Tradução de Torres Filho, R. In:Antologia de Textos Filosóficos. MARÇAL, J. (org.). Paraná: SEED, 1873/2009.

NÓBREGA, M. Rima e poesia. Rio de Janeiro: Instituto Nacional do Livro, 1965.

GUERINI, A.; VERÇOSA, F.B.S. Ivo Barroso. In: GUERINI, A.; TORRES, Marie Helene (Org.) ; FURLAN, Mauri (Org.) ; COSTA, Walter Carlos (Org.) ; HEIDERMANN, W. (Org.). Dicionário de tradutores literários no Brasil. Florianópolis: $\quad$ NUT, 2005.2 Disponível em:http://www.dicionariodetradutores.ufsc.br/pt/lvoBarroso.htm. Acesso em: 13 abr.2017.

PROJETO CALDAS AULETE. Aulete Digital. Lexikon Editora Digital: Rio de Janeiro, 2006. Disponível em: http://www.aulete.com.br/. Acesso em: 09 fev. 2017.

REISS, Katharina. Translation criticism - The potentials and limitations: categories and criteria for translation quality assessment. Translated by Erroll F. Rhodes. Manchester, UK: St. Jerome Publishing, 2000. 
SANTOS, Diana ; MARQUES, Rui ; FREITAS, Cláudia ; SIMÕES, Alberto ; MOTA, Cristina. Comparando anotações linguísticas na Gramateca: filosofia, ferramentas e exemplos. Domínios de Lingu@Gem, Uberlândia, v. 9, n22, abrjun, p. 11-26, 2015.

SHAKESPEARE, W. 42 sonetos. Tradução e introdução de Ivo Barroso. Rio de Janeiro: Nova Fronteira, 2005.

Sonetos. Tradução e notas de Jorge Wanderley. Rio de Janeiro: Civilização Brasileira, 1991.

TAVARES, B. Contando histórias em verso: Poesia e romanceiro popular no Brasil. São Paulo: Editora 34, 2005.

WHITMAN, W.Canto de mim mesmo. Tradução de José Agostinho Baptista. Lisboa: Assírio \& Alvim, 1992.

WILLIAMS, W.C. Metric Figure. In: Marques, O. Videntes e sonâmbulos: coletânea de poemas norte-americanos. Rio de Janeiro: Ministério da educação e cultura - Serviço de documentação, 1955. 


\section{Anexos}

10.1

Anexos A: estudos de caso

\subsection{1}

\section{Estudo de caso 1}

\section{My mistress' eyes are nothing like the sun;} Coral is far more red than her lips' red; If snow be white, why then her breasts are

If hairs be wires, black wires grow on her

[head.

I have seen roses damasked, red and white, But no such roses see I in her cheeks; And in some perfumes is there more delight Than in the breath that from my mistress [reeks.

I love to hear her speak, yet well I know That music hath a far more pleasing sound; I grant I never saw a goddess go; My mistress when she walks treads on the [ground.

And yet, by heaven, I think my love as rare As any she belied with false compare. [dun;
Seus olhos nada têm de um sol que arda E mais rubro é o coral que sua boca: Se a neve é branca, sua tez é parda;

São fios negros seu cabelo em touca.

Vi rosas mesclas de rubor e alvura, Mas tais rosas não vejo em sua face. Sei de perfumes que têm mais doçura Que o hálito da amada evolasse.

Amo ouvi-la falar, porém insisto Que mais me agrada ouvir uma canção. De deusas nunca devo o andar ter visto Minha amante ao andar pisa no chão.

No entanto, pelos céus, acho-a mais rara Do que a mulher que em falso se compara. 


\section{1 .2}

\section{Estudo de caso 2}

My mistress' eyes are nothing like the sun;

Coral is far more red than her lips' red;

If snow be white, why then her breasts are

[dun;

If hairs be wires, black wires grow on her

[head.

I have seen roses damasked, red and white,

But no such roses see I in her cheeks;

And in some perfumes is there more delight

Than in the breath that from my mistress

[reeks.

I love to hear her speak, yet well I know

That music hath a far more pleasing sound;

I grant I never saw a goddess go;

My mistress when she walks treads on the

[ground.

And yet, by heaven, I think my love as rare

As any she belied with false compare.
O seu olhar não é o de um sol puro;

Nenhum coral os lábios lhe acendeu;

Se a neve é branca, os seios tem escuros;

Se são fio os cabelos, negro é o seu.

Já vi rosas damasco, branco-e-rosa,

Porém nenhuma em sua face esplende

E há muita essência bem mais perfumosa

Que os hálitos que dela se desprendem.

Adoro a sua voz, ainda quando

Saiba mais doce o som de uma canção;

Nunca vi uma deusa caminhando;

Já minha amada, andando esflora o chão:

Mas, pelos céus, eu creio que é tão rara

Quanto as que em falsa imagem se comparam.

10.2

Anexos B: guias

10.2.1

Guia SL1

Exemplos: poema, autor e tradutor

\begin{tabular}{l|l|l} 
POEMA $^{25}$ & AUTOR & TRADUTOR
\end{tabular}

25 Todos os originais e as traduções deste quadro podem ser encontrados em MENEZES (2012), disponível em:

http://www2.dbd.puc-rio.br/pergamum/biblioteca/php/mostrateses.php?open=1\&arqtese=1112728 2012 Indice.html 


\begin{tabular}{|c|c|c|}
\hline Catarina to Camoens & Elizabeth Barrett Browning & Fernando Pessoa \\
\hline To a skylark & Percy Bysshe Shelley & Fernando Pessoa \\
\hline $\begin{array}{c}\text { The last metamorphosis of } \\
\text { Mephistopheles }\end{array}$ & Frank Marzials & Fernando Pessoa \\
\hline
\end{tabular}

\section{CategoriasSL1: explicações e exemplos}

\section{DUPLICAÇÃO}

É a estratégia que consiste em traduzir os elementos semânticos presentes em um termo ou trecho de um dado verso ou dada estrofe do original por dois termos ou trechos que expressam esses mesmos elementos semânticos, no verso ou na estrofe correspondente da tradução. As DUPLICAÇÕES devem ser anotadas da seguinte forma: $\{\text { XXXXX }\}^{\text {dup }}$, mantendo sempre o termo ou o trecho a ser anotado entre duas chaves.

But all changes. At this vesper,
$\{\text { Cold }\}^{\text {dup }}$ the sun shines down the door.
If you stood there, would you whisper
"Love, I love you,"asbefore,--
Death pervading
Now, and shading
Eyes you sang of, that yestreen,
$[\ldots]$

Mas tudo muda. Nesta tarde $\{\text { fria }\}^{\text {dup }}$ O sol bate na porta $\{\text { sem calor }\}^{\text {dup }}$. Se estivesses aí murmuraria Como dantes tua voz - "amo-te, amor"; A morte chega E já cega Os olhos que ontem eram teus desvelos [...]

O sentido de "cold" foi duplicado em "fria" e "sem calor".

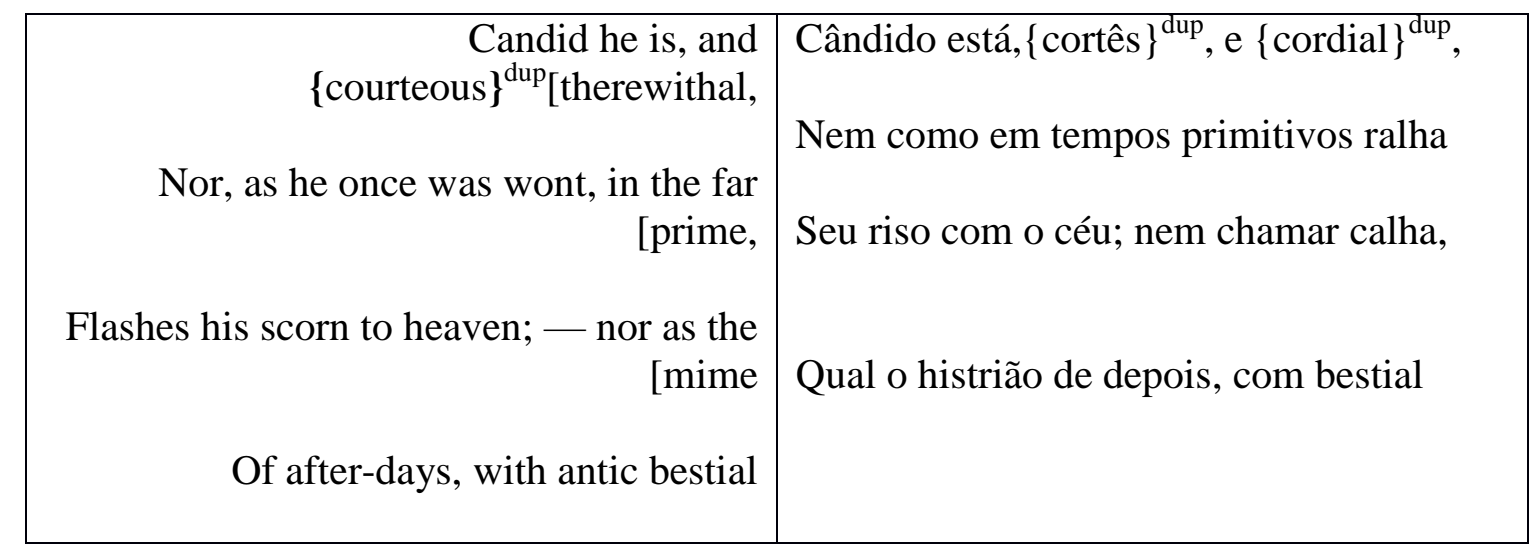


O sentido de "courteous" foi duplicado em "cortês" e "cordial".

\section{ENXUGAMENTO}

É a estratégia que consiste em "enxugar", "resumir" os elementos semânticos de um dado trecho do original em um trecho correspondente na tradução. Os ENXUGAMENTOS devem ser anotados da seguinte forma: $\{\text { XXXXX }\}^{\text {enx }}$, mantendo sempre o termo ou o trecho a ser anotado entre duas chaves.

Ex:

\begin{tabular}{|c|c|}
\hline $\begin{array}{r}\text { But now, }\{\text { in courtliest modes of cultured } \\
{[\text { grace, }\}^{\text {enxi }}}\end{array}$ & Mas agora, $\{\text { com culta cortesia }\}^{\text {enxI }}$, \\
\hline $\begin{array}{r}\text { He glories in the growth of good, his } \\
\text { [glance }\end{array}$ & 'stima do bem o aumento, e o seu olhar \\
\hline Beaming benignant as he bids us trace & Brilha benigno, e aponta em tudo o dia \\
\hline $\begin{array}{r}\text { Good everywhere - till, as meremotes } \\
\text { [that dance }\end{array}$ & Do bem, e, como pó no sol a ondear, \\
\hline $\begin{array}{l}\text { Athwart the sunbeams, }\{\text { all things evil and } \\
{[\text { base }\}^{\text {enx2 }}}\end{array}$ & $\{\text { Todo o mal }\}^{\text {enx2 }}$ fulge do ouro que irradia \\
\hline Glint golden in his genial tolerance. & A sua tolerância modelar. \\
\hline
\end{tabular}

No primeiro terceto, temos o enxugamento dos elementos semânticos de "in courtliestmodesofculturedgrace" (nos modos mais corteses da graça culta) em "com culta cortesia". No segundo terceto, temos enxugamento dos elementos semânticos de "all things evil and base" (todas as coisas ruins e vis) em "Todo o mal".

\section{OBSERVAÇÃO 1:}

A fim de evitar confusão, o anotador pode, sempre que as categorias se repetirem em um mesmo estudo de caso, numerar, com algarismos arábicos, as etiquetas na anotação, como no primeiro exemplo de ENXUGAMENTO acima: o trecho 
$\{\mathrm{XXXXX}\}^{\text {enx1 }}$ do original corresponde ao trecho $\{\mathrm{XXXXX}\}^{\text {enx1 }}$ da tradução; e o trecho $\{\mathrm{XXXXX}\}^{\text {enx2 }}$ do original corresponde ao trecho $\{\mathrm{XXXXX}\}^{\text {enx2 }}$ da tradução.

\section{EXPLICITAÇÃO}

É a estratégia em que um trecho da tradução explicita elementos semânticos implícitos no trecho correspondente do original. De forma mais detalhada, podemos dizer que a EXPLICITAÇÃO caracteriza-se pela presença, na tradução, de significantes que apontam significados que podem ser inferidos a partir dos significantes originais. As EXPLICITAÇÕES devem ser anotadas da seguinte forma: $\{\text { XXXXX }\}^{\text {exp }}$, mantendo sempre o termo ou o trecho a ser anotado entre duas chaves.

Ex:

$\{\text { When the angelus is ringing }\}^{\exp }$, Near the convent will you walk, And recall the choral singing Which brought angels down our talk? Spirit-shriven I viewed Heaven, Till you smiled--"Is earth unclean, $[\ldots]$ $\{\text { Quando o angelus toca à oração }\}^{\exp }$, Não passarás ao pé deste convento, Lembrando-te, a chorar, do cantochão Que anjos traziam-nos do firmamento? No ardor meu Eu via o céu E tu: "O mundo é vil, ó meus desvelos, $[\ldots]$

Aqui, o sentido implícito em "Whenthe angelus isringing" (Quando o ângelus soa) está explicitado em "Quando o ângelus toca à oração": o soar do ângelus é uma chamada para a oração. Podemos dizer, mais detalhadamente, que "à oração" é uma cadeia de significantes que não tem contraparte no original — já que when, theangelus e isringing têm cada um seu termo correspondente na tradução - mas cujo significado estaria contido na definição de dicionário de angelus — "uma forma de devoção que comemora a Encarnação e é dita de manhã, ao meio-dia, e à noite pelos católicos geralmente ao som de um sino ${ }^{26,}$ - já que devotion, por sua vez, tem como

\footnotetext{
${ }^{26}$ Original: "a form of devotion that commemorates the Incarnation and is said in the morning, at noon, and at night by Roman Catholics usually at the sounding of a bell". (Webster's Third, 2000).
} 
uma de suas acepções "um ato de devoção religiosa; geralmente: um ato de oração ou súplica ${ }^{27}$ ", onde aparece a palavra prayer, que pode ser traduzida como "oração".

\section{DESLOCAMENTO}

É a estratégia de tradução que consiste em manter os elementos semânticos de um termo ou trecho do original, porém deslocando o termo ou trecho que se encontra em um dado verso do original para um outro verso da tradução. O termo ou trecho pode ser deslocado para um outro verso da mesma estrofe, ou então para um outro verso da estrofe anterior ou posterior. Os DESLOCAMENTOS devem ser anotados da seguinte forma: $\{\text { XXXXX }\}^{\text {des }}$, mantendo sempre o termo ou o trecho a ser anotado entre duas chaves.

Ex:

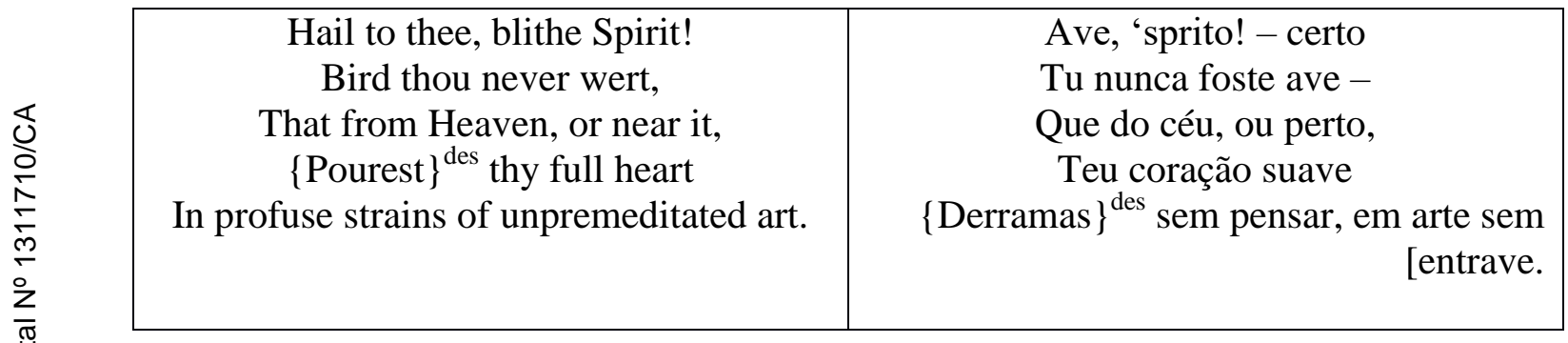

O sentido de "pourest", que se encontra no quarto verso da estrofe original, foi deslocado para o quinto verso da estrofe traduzida: "Derramas".

\begin{tabular}{|c|c|}
\hline $\begin{array}{l}\text { But-butnow-\{yet unremoved } \\
\text { Up to heaven }\}_{\text {des }}^{\text {,they glisten fast; }} \\
\text { You may cast away, Beloved, } \\
\text { In your future all my past: } \\
\text { Such old phrases } \\
\text { May be praises } \\
\text { For some fairer bosom-queen-- } \\
{[\ldots]}\end{array}$ & $\begin{array}{l}\text { Mas agora, \{esta terra inda os } \\
\quad \text { [prendendo }\}^{\text {des }}, \\
\text { Desses olhos o brilho é inda alado... } \\
\text { Amor, tu poderás encher, querendo, } \\
\text { Teu futuro de todo o meu passado, } \\
\text { E tornar } \\
\text { A cantar } \\
\text { A outra dama ideal dos teus desvelos: } \\
\text { [...] }\end{array}$ \\
\hline
\end{tabular}

${ }^{27}$ Original: "an act of religious devotion; usually: an act of prayer or supplication".(Webster's Third, 2000). 
O sentido de "yetunremoved / Uptoheaven", que se encontra no primeiro e no segundo versos da estrofe original, foi deslocado para o primeiro verso da estrofe traduzida: "esta terra inda os prendendo".

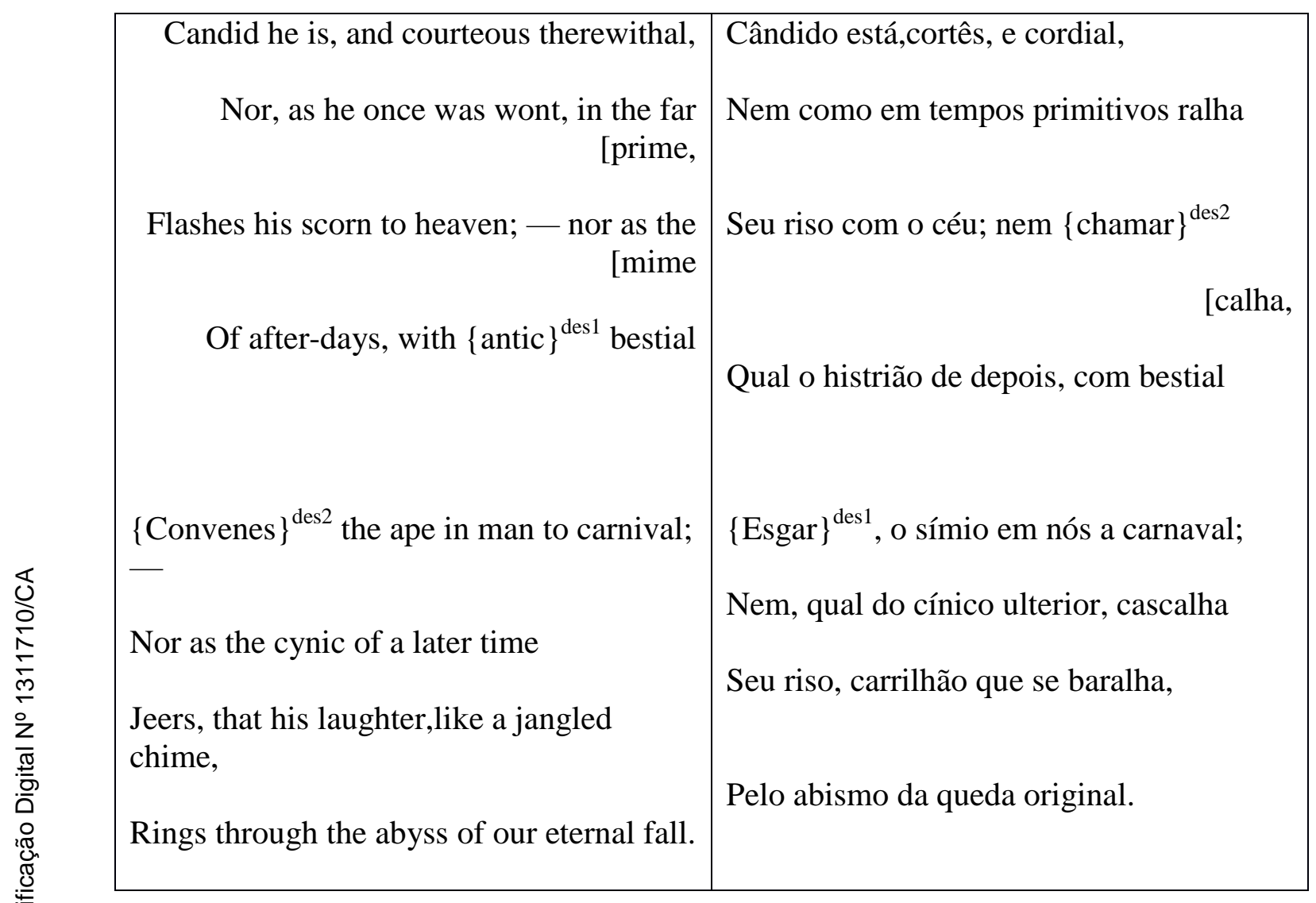

Nesses quartetos, há deslocamento do sentido de "antic" do quarto verso do primeiro quarteto, para o primeiro verso do segundo quarteto: “esgar”. Também há deslocamento do sentido de "Convenes", do primeiro verso do segundo quarteto, para o terceiro verso do primeiro quarteto: "chamar".

\section{INVERSÃO}

É a estratégia de tradução que consiste em inverter a ordem das palavras de um trecho do original no trecho correspondente da tradução. As INVERSÕES devem ser 
anotadas da seguinte forma: $\{\mathrm{XXXXX}\}^{\text {inv }}$, mantendo sempre o termo ou o trecho a ser anotado entre duas chaves.

Ex:

What thou art we know not;

What is most like thee?

From rainbow clouds there flow not

Drops so bright to see,

\{As from thy presence showers a rain of
O que és não sabemos;

Quem te igualaria?

Das nuvens não vemos

Chover alegria, \{Qual chove sobre nós de ti a melodia. $\}^{\text {inv }}$ $[\text { melody. }]^{\text {inv }}$

O trecho do original "As fromthy presence showers a rainof melody" (Qual de ti chove sobre nós a melodia) sofre inversão na tradução: "Qual chove sobre nós de ti a melodia".

$\{\text { Eyes of mine, what are ye doing? }\}^{\text {inv }}$ Faithless, faithless,--praised amiss If a tear be of your showing, Dropt for any hope of HIS!

Death has boldness

Besides coldness, If unworthy tears demean

"Sweetest eyes, were ever seen." $\{\text { Mas que fazeis, meus olhos }\}^{\text {inv }}$, ó [perjuros!

Perjuros ao louvor que ele vos deu, Se esta hora mesmo vos não mostrais puros

De lágrima que acaso vos encheu?

Será forte

Choro ou morte

Se indignos os tornar de teus desvelos

- O lindo ser dos vossos olhos belos.

O trecho do original "Eyes of mine, what are ye doing?" (Olhos meus, mas que fazeis?)

sofre inversão na tradução: "Mas que fazeis, meus olhos, [...]”.

\section{ALTERAÇÃO SEMÂNTICA}

É a estratégia que consiste em traduzir um termo ou trecho do original alterando seus elementos semânticos em um termo ou trecho correspondente da tradução. As ALTERAÇÕES SEMÂNTICAS devem ser anotadas da seguinte forma: \{ XXXXX \}$^{\text {asem }}$, mantendo sempre o termo ou o trecho a ser anotado entre duas chaves. 
Ex:

Convenes the ape in man to carnival; Nor as the cynic of a later time

Jeers, that his laughter,like a jangled

[chime,

Rings through the abyss of our
Esgar, o símio em nós a carnaval;

Nem, qual do cínico ulterior, cascalha

Seu riso, carrilhão que se baralha,

$$
\{\text { eternal }\}^{\text {asem }} \text { fall. } \text { Pelo abismo da queda }\{\text { original }\}^{\text {asem }} \text {. }
$$

Encontramos alteração semântica na tradução de "eternal” (eterno) por “original”.

\section{OMISSÃO}

É a estratégia de tradução que consiste na omissão de elementos semânticos presentes em um termo ou um trecho da estrofe do original. As OMISSÕES devem ser anotadas da seguinte forma: $\{\text { XXXXX }\}^{\text {omi }}$, mantendo sempre o termo ou o trecho a ser anotado entre duas chaves.

Ex:

\begin{tabular}{|c|c|}
\hline Like a rose embowered & Qual rosa que mora \\
In its own green leaves, & No cálice verde, \\
By $\{\text { warm }\}^{\text {omi }}$ winds deflowered, & E o vento desflora, \\
Till the scent it gives & E o aroma que cede \\
Makes faint with too much sweet those & Embriaga o alado roubador que a perde: \\
[heavy-wingèd thieves: & \\
\hline
\end{tabular}

O sentido de "warm" (quente) não está presente em nenhum dos versos da estrofe traduzida. Isso caracteriza a OMISSÃO de "warm”.

\begin{tabular}{|c|c|}
\hline IV & IV \\
The pale purple even & A púrpura cálida \\
Melts around thy flight; & Em torno a ti esfria; \\
Like a star of Heaven, & Como estrela pálida \\
In the broad daylight & No já pleno dia \\
Thou art unseen, but yet I hear thy & Não te vejo, mas ouço essa tua alegria. \\
& \\
\hline shrill $\}^{\text {omi }}$ delight, & \\
\hline
\end{tabular}


O sentido de "shrill” (estridente) não está presente em nenhum dos versos da estrofe traduzida. Isso caracteriza a omissão de "shrill”.

\section{ACRÉSCIMO}

É a estratégia de tradução que consiste no acréscimo de elementos semânticos que não estão presentes na estrofe do original, através de um termo ou um trecho da tradução. Os ACRÉSCIMOS devem ser anotados da seguinte forma: $\{\mathrm{XXXXX}\}^{\text {acr }}$, mantendo sempre o termo ou o trecho a ser anotado entre duas chaves.

Ex:

When the angelus is ringing, Near the convent will you walk, And recall the choral singing Which brought angels down our talk? Spirit-shriven I viewed Heaven, Till you smiled--"Is earth unclean, $[\ldots]$
Quando o angelus toca à oração, Não passarás ao pé deste convento, Lembrando-te, $\{\text { a chorar }\}^{\text {acr }}$, do cantochão Que anjos traziam-nos do firmamento? No ardor meu Eu via o céu E tu: "O mundo é vil, ó meus desvelos, $[\ldots]$

O sentido de "a chorar" não está presente em nenhum dos versos da estrofe original. Isso caracteriza o ACRÉSCIMO de "a chorar".

\begin{tabular}{|c|c|}
\hline XV & XV \\
What objects are the fountains & Que coisas são fontes \\
Of thy happy strain? & Do teu canto em flor? \\
$\begin{array}{r}\text { What fields, or waves, or mountains? } \\
\text { What shapes of sky or plain? } \\
\text { What love of thine own kind? what } \\
\text { [ignorance of pain? }\end{array}$ & Que ondas, campos, montes? \\
& Que céu, de que cor? \\
& iimenso $\}^{\text {acr }}$ amor dos teus, que \\
[ignorância da dor?
\end{tabular}

O sentido de "imenso" não está presente em nenhum dos versos da estrofe original. Isso caracteriza o ACRÉSCIMO de "imenso". 


\section{Sobreposição de categorias}

Pode haver sobreposição de categorias em um mesmo trecho. As sobreposições devem ser anotadas da seguinte maneira: $\{X X X X X\}^{\mathrm{y}, \mathrm{z}}$, onde " $\mathrm{y}$ " é uma categoria e " $\mathrm{z}$ " é uma outra, mantendo sempre o termo ou o trecho a ser anotado entre duas chaves, seguindo a numeração das categorias, de acordo com a OBSERVAÇÃO 1 deste guia.

Ex:

\begin{tabular}{|c|c|}
\hline Convenes the ape in man to carnival; - & Esgar, o símio em nós a carnaval; \\
\hline Nor as the cynic of a later time & Nem, qual do cínico ulterior, $\{$ cascalha \\
\hline $\begin{array}{r}\text { \{Jeers, that his laughter,like a jangled } \\
\text { [chime, }\end{array}$ & Seu riso, carrilhão que se baralha, $\}^{\text {enx, des }}$ \\
\hline $\begin{array}{r}\text { Rings }\}^{\text {enx, des }} \text { through the abyss of our } \\
\text { eternal fall. }\end{array}$ & Pelo abismo da queda original. \\
\hline
\end{tabular}

\section{Exemplo de estudo de caso}

\begin{tabular}{l|l}
$\begin{array}{l}\text { Candid he is, and courteous therewithal, } \\
\text { Nor, as he once was wont, in the far prime, }\end{array}$ & $\begin{array}{l}\text { Cândido está,cortês, e cordial, } \\
\text { Nem como em tempos primitivos ralha } \\
\text { Flashes his scorn to heaven; - nor as the } \\
\text { [mime } \\
\begin{array}{l}\text { Of after-days, with antic bestial }\end{array}\end{array}$ \\
$\begin{array}{l}\text { Seu riso com o céu; nem chamar calha, } \\
\text { Qual o histrião de depois, com bestial }\end{array}$
\end{tabular}

Convenes the ape in man to carnival; -

Nor as the cynic of a later time

Jeers, that his laughter, like a jangled chime,

Rings through the abyss of our eternal fall.
Esgar, o símio em nós a carnaval;

Nem, qual do cínico ulterior, cascalha

Pelo abismo da queda original.
Seu riso, carrilhão que se baralha, 


\begin{tabular}{|l|l|}
\hline $\begin{array}{l}\text { But now, in courtliest modes of cultured } \\
\text { [grace, }\end{array}$ & Mas agora, com culta cortesia, \\
Beaming benignant as he bids us trace & Brilha benigno, e aponta em tudo o dia \\
[dance & 'stima do bem o aumento, e o seu olhar \\
Good everywhere - till, as mere motes that & Do bem, e, como pó no sol a ondear, \\
Athwart the sunbeams, all things evil and base & Todo o mal fulge do ouro que irradia \\
Glint golden in his genial tolerance. & A sua tolerância modelar. \\
& \\
\hline
\end{tabular}

\section{Anotação}

\begin{tabular}{|c|c|}
\hline $\begin{array}{r}\text { Candid he is, }\{\text { and }\}^{\text {enxl }}\{\text { courteous }\}^{\text {dupl } 1} \\
\quad\left[\{\text { therewithal }\}^{\text {enx1 }},\right.\end{array}$ & $\begin{array}{l}\text { Cândido está, }\{\text { cortês }\}^{\text {dupl } 1},\{\text { e }\}^{\text {enxl }} \\
\\
{\left[\{\text { cordial }\}^{\text {dup } 1},\right.}\end{array}$ \\
\hline $\begin{array}{c}\text { Nor, }\{\text { as he once was wont }\}^{\circ \mathrm{omi}} \text {, in the far } \\
\text { [prime, }\end{array}$ & Nem como em tempos primitivos $\{$ ralha \\
\hline $\begin{array}{r}\{\text { Flashes his scorn }\}^{\text {des } 1} \text { to heaven; - nor }\{\text { as } \\
\text { [the mime }\end{array}$ & $\begin{array}{l}\text { Seu riso }\}^{\text {des1 }} \text { com o céu; nem } \\
\qquad\left[\{\text { chamar }\}^{\text {des } 4}\{\text { calha }\}^{\text {acr } 1},\right.\end{array}$ \\
\hline Of after-days $\}^{\text {des } 2}$, with $\{\text { antic }\}^{\text {des3 } 3}$ bestial & $\{\text { Qual o histrião de depois }\}^{\text {des } 2}$, com bestial \\
\hline$\{\text { Convenes }\}^{\text {des } 4}$ the ape in man to carnival; - & $\{\text { Esgar }\}^{\text {des3 }}$, o símio em nós a carnaval; \\
\hline Nor as the cynic of a later time & Nem, qual do cínico ulterior, \{cascalha \\
\hline $\begin{array}{l}\{\text { Jeers, that his laughter, like a jangled } \\
\text { [chime, }\end{array}$ & Seu riso, carrilhão que se baralha, $\}^{\text {enx2,des5 }}$ \\
\hline $\begin{array}{r}\text { Rings }\}^{\text {enx2,des5 }} \text { through the abyss of our } \\
{\left[\{\text { eternal }\}^{\text {asem1 }} \text { fall. }\right.}\end{array}$ & Pelo abismo da queda $\{\text { original }\}^{\text {asem } 1}$ \\
\hline
\end{tabular}




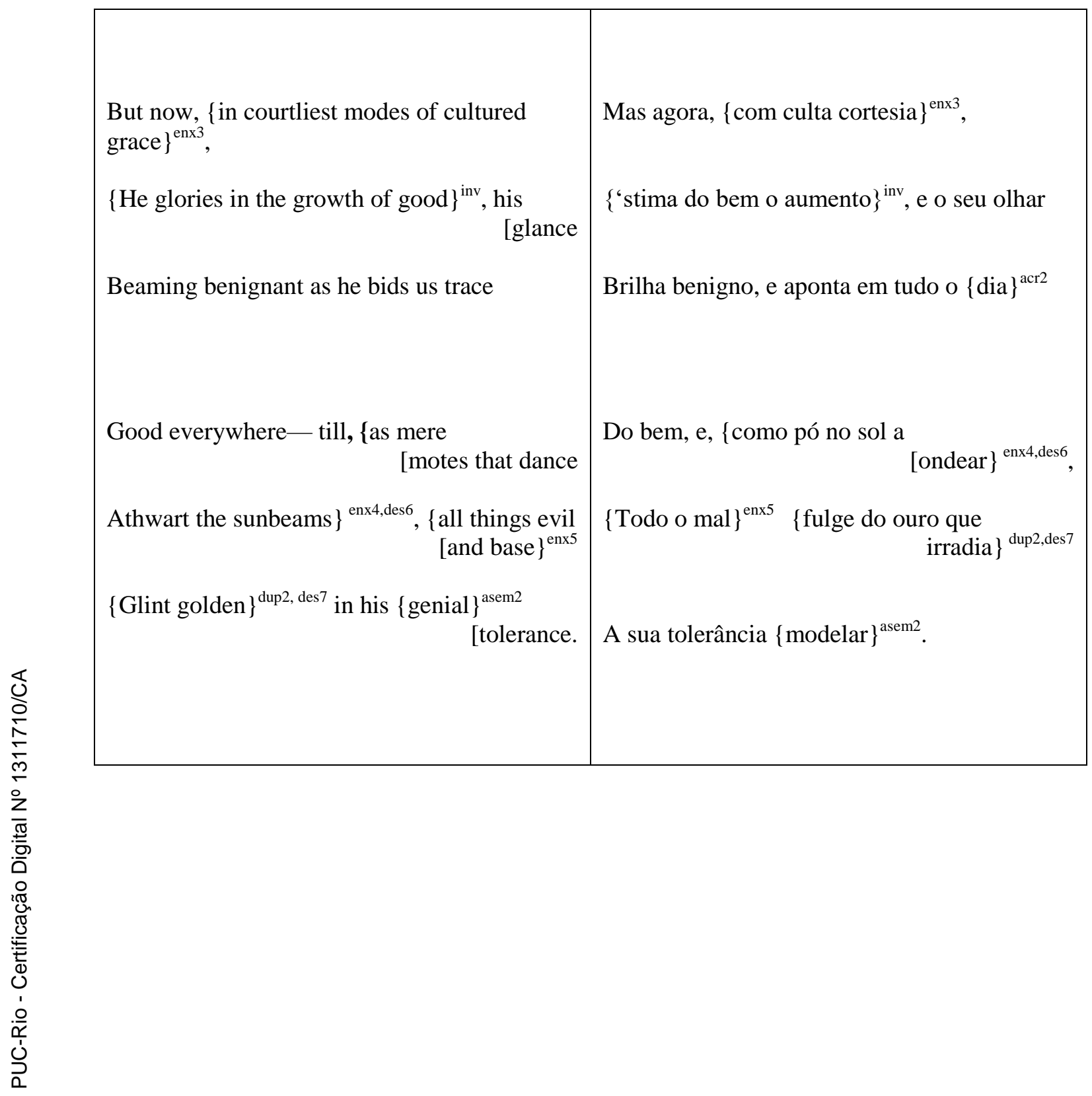

10.2 .2

Guia SL2

Exemplos: poema, autor e tradutor 


\begin{tabular}{|c|c|c|}
\hline POEMA & AUTOR & TRADUTOR \\
\hline To a skylark & Percy Bysshe Shelley & Fernando Pessoa \\
\hline Elegie XIX: Going to bed ${ }^{28}$ & John Donne & Paulo Vizioli \\
\hline Elegie XIX: Goind to bed & John Donne & Augusto de Campos \\
\hline
\end{tabular}

\section{Categorias SL2: explicações e exemplos}

\section{ALTERAÇÃO SEMÂNTICA}

É a estratégia que consiste em traduzir um substantivo, adjetivo, uma oração/um período ou verso do original alterando seus elementos semânticos em um substantivo, adjetivo, uma oração/um período ou verso correspondente da tradução. As ALTERAÇÕES SEMÂNTICAS devem ser anotadas da seguinte forma: $\{X X X X X\}^{\text {asem }}$, no original e na tradução, mantendo sempre o termo ou o trecho a ser anotado entre duas chaves. As alterações semânticas que ocorrerem entre conjunções, artigos, preposições e pronomes isolados, da tradução e do original, não serão levadas em consideração.

Podemos considerar que há alteração de elementos semânticos do original nos seguintes casos, em que a tradução não utiliza sinônimos, hipônimos ou hiperônimos:

\begin{tabular}{|l|l|}
\hline $\begin{array}{l}\text { Pourest thy }\left\{\text { full }^{\text {asem }}{ }^{\text {In profuse strains of unpremeditated art }}\right. \\
\text { Derramas sem pensar, em arte sem } \\
\text { [entrave }\end{array}$ \\
\hline
\end{tabular}

Nesse caso, temos "suave" como a tradução de "full" (pleno , repleto). "Suave" não é sinônimo, hipônimo ou hiperônimo de "pleno, repleto", dessa forma, podemos dizer que há alteração semântica na tradução de "full” por "suave".

\begin{tabular}{|l|l|}
\hline$\{\text { Melts }\}^{\text {asem }}$ around thy flight & Em torno a ti $\{\text { esfria }\}^{\text {asem }}$ \\
\hline
\end{tabular}

\footnotetext{
${ }^{28}$ O poema "Elegie XIX:Going to bed", original e suas traduções, podem ser encontrados em BRITTO (2006b).
} 
Nesse caso, temos "esfria" como a tradução de "melts" (derrete). "Esfria" não é sinônimo, hipônimo ou hiperônimo de "derrete", de/ssa forma, podemos dizer que há alteração semântica na tradução de "melts" por "esfria".

$$
\begin{array}{|l|l}
\hline \text { Of thy }\{\text { happy }\}^{\text {asem }} \text { strain? } & \text { Do teu canto }\{\text { em flor }\}^{\text {asem }} ?
\end{array}
$$

Nesse caso, temos "em flor" como a tradução de "happy" (feliz, alegre, contente). "Em flor" não é sinônimo, hipônimo ou hiperônimo de "feliz, alegre, contente", dessa forma, podemos dizer que há alteração semântica na tradução de "happy" por "em flor".

\section{OBSERVAÇÃO:}

A fim de evitar confusão, o anotador pode, sempre que as categorias se repetirem em um mesmo estudo de caso, numerar, com algarismos arábicos, as etiquetas na anotação: o trecho $\{\mathrm{XXXXX}\}^{\text {asem1 }}$ do original corresponderia ao trecho $\{\mathrm{XXXXX}\}^{\text {asem1 }}$ da tradução; e o trecho $\{\mathrm{XXXXX}\}^{\text {asem2 }}$ do original corresponderia ao trecho $\{\mathrm{XXXXX}\}^{\text {asem2 }}$ da tradução, por exemplo.

\section{OMISSÃO}

É a estratégia de tradução que consiste na omissão de elementos semânticos presentes em um substantivo, adjetivo, uma oração/um período ou verso da estrofe do original. As OMISSÕES devem ser anotadas da seguinte forma: $\{\mathrm{XXXXX}\}^{\text {omi }}$, no original, mantendo sempre o termo ou o trecho a ser anotado entre duas chaves. As omissões de conjunções, artigos, preposições e pronomes isolados não serão levadas em consideração. 


\begin{tabular}{|l|l|}
\hline $\begin{array}{l}\text { Athee } \\
\{I l l\}^{\text {omi }} \text { spirits walk in white, we easly know }\end{array}$ & $\begin{array}{l}\text { Semelhança os espíritos }[\mathrm{XXXX}]^{\text {omi }} \text {, distingo: } \\
\text { By this these Angels from an evil sprite, } \\
\text { Those set our hairs, but these our flesh }\end{array}$ \\
$\begin{aligned} \text { O que o meu Anjo branco põe não é } \\
\text { O cabelo mas sim a carne em pé. }\end{aligned}$ \\
\end{tabular}

No caso em questão, há omissão de "Ill” (maus), resultando na ausência, na tradução, da distinção entre espíritos maus e anjos bons.

\section{ACRÉSCIMO}

É a estratégia de tradução que consiste no acréscimo de elementos semânticos que não estão presentes na estrofe do original, através de um substantivo, adjetivo, uma oração/ um período ou verso da tradução. Os ACRÉSCIMOS devem ser anotadosda seguinte forma: $\{\mathrm{XXXXX}\}^{\text {acr }}$, na tradução, mantendo sempre o termo ou o trecho a ser anotado entre duas chaves. Os acréscimos de conjunções, artigos, preposições e pronomes isolados não serão levados em consideração.

\begin{tabular}{|l|r|}
\hline To teach thee, I am naked first; why than & $\begin{array}{r}\text { Que esperas?Estou nu... }\{\text { e as horas } \\
{[\text { se consomem }\}^{\text {acr }}}\end{array}$ \\
What needst thou have more covering & Mais cobertura tu desejas do que um \\
[then a man & [homem? \\
\hline
\end{tabular}

Nesses dois últimos versos da tradução, encontramos acréscimo de "e as horas se consomem". Tal trecho contém elementos semânticos que não encontramos no verso correspondente do original e, na verdade, em verso nenhum do original. No poema em inglês, temos a ideia de que o homem tira a roupa para ensinar a mulher a fazê-lo, sem pressa, enquanto que, na tradução, vemos o homem perdendo a paciência com a mulher, querendo que eles façam sexo logo. Acréscimos como esses ocorreram com frequência ao longo de toda a tradução em questão. 


\section{Exemplo de estudo de caso}

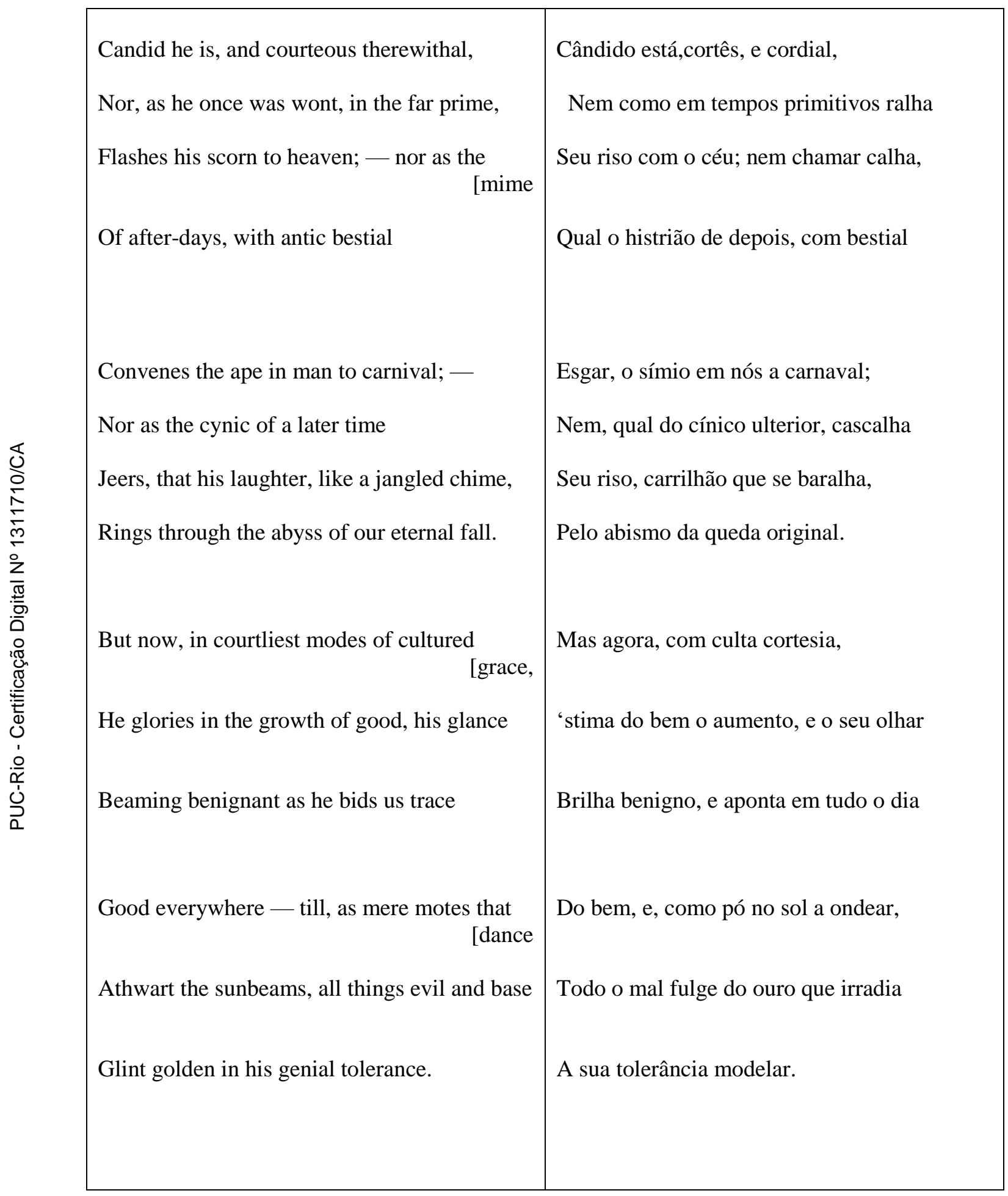




\section{Anotação}

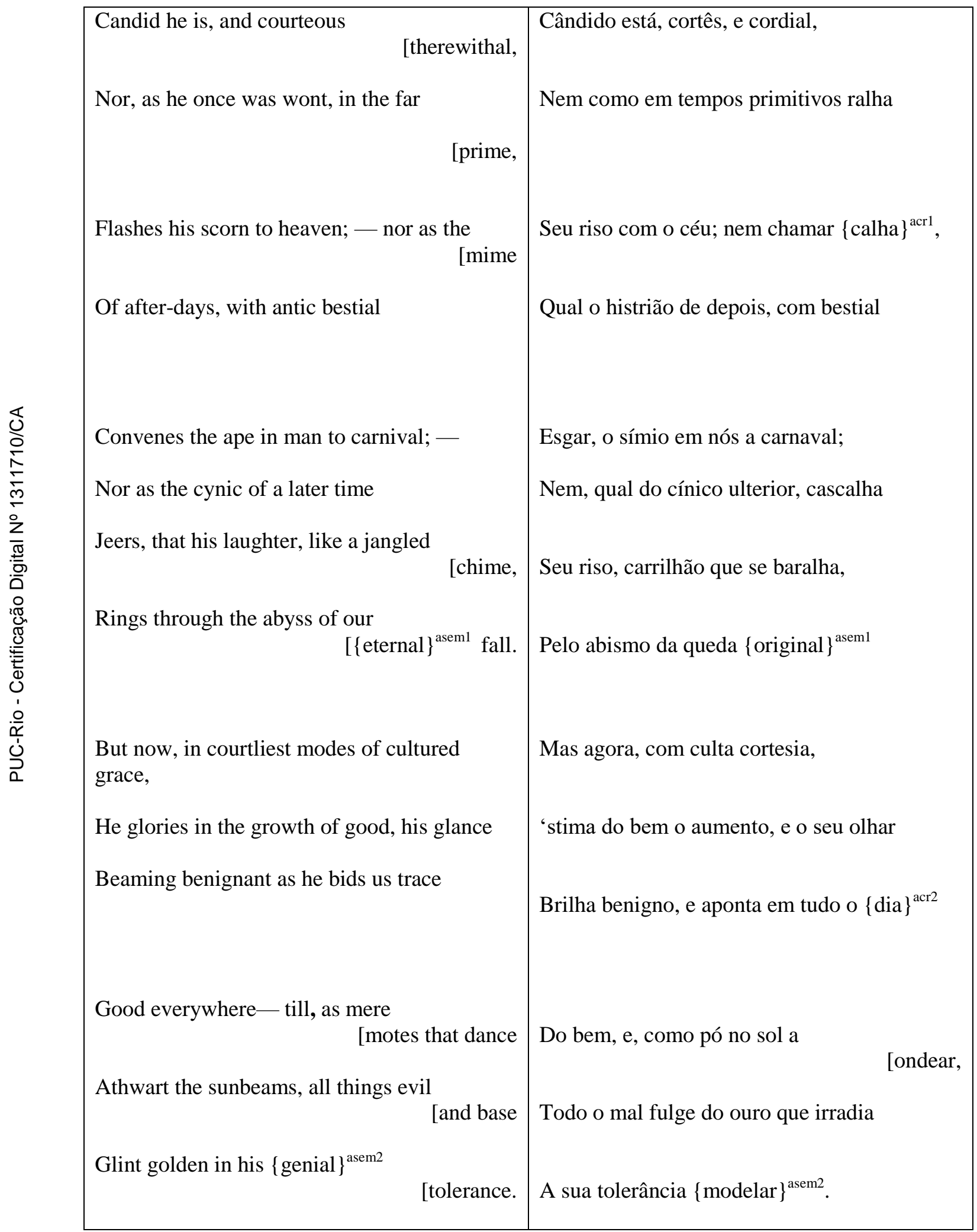




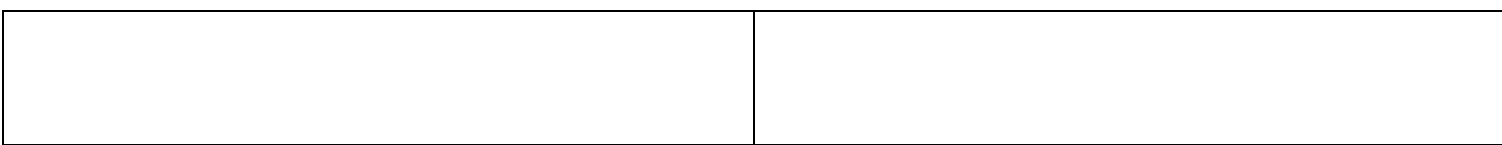

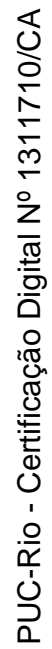

10.2.3

Guia SL3

Exemplos: poema, autor e tradutor 


\begin{tabular}{|c|c|c|}
\hline POEMA & AUTOR & TRADUTOR \\
\hline To a skylark & Percy Bysshe Shelley & Fernando Pessoa \\
\hline Elegie XIX:Going to bed & John Donne & Paulo Vizioli \\
\hline Elegie XIX:Going to bed & John Donne & Augusto de Campos \\
\hline
\end{tabular}

\section{Categorias SL3: explicações e exemplos}

\section{ALTERAÇÃO SEMÂNTICA}

É a estratégia que consiste em traduzir um substantivo, adjetivo, advérbio, verbo, uma oração/um período ou verso do original alterando seus elementos semânticos em um substantivo, adjetivo, advérbio, verbo, uma oração/um período ou verso correspondente da tradução. As ALTERAÇÕES SEMÂNTICAS devem ser anotadas da seguinte forma: $\{\mathrm{XXXXX}\}^{\text {asem }}$, no original e na tradução, mantendo sempre o termo ou o trecho a ser anotado entre duas chaves. As alterações semânticas que ocorrem entre conjunções, artigos, preposições e pronomes isolados, da tradução e do original, não serão levadas em consideração.

Podemos considerar que há alteração de elementos semânticos do original nos seguintes casos, em que a tradução não utiliza sinônimos, hipônimos ou hiperônimos:

\begin{tabular}{|l|l|}
\hline $\begin{array}{l}\text { Pourest thy }\{\text { full }\}^{\text {asem }} \text { heart } \\
\text { In profuse strains of }\end{array}$ & $\begin{array}{l}\text { Teu coração }\{\text { suave }\}^{\text {asem }} \\
\text { Derramas sem pensar, em }\end{array}$ \\
[unpremeditated art & [arte sem entrave \\
\hline
\end{tabular}

Nesse caso, temos "suave" como a tradução de "full" (pleno , repleto). "Suave" não é sinônimo, hipônimo ou hiperônimo de "pleno, repleto", dessa forma, podemos dizer que há alteração semântica na tradução de "full” por "suave".

\begin{tabular}{|l|l|}
\hline$\{\text { Melts }\}^{\text {asem }}$ around thy flight & Em torno a ti $\{\text { esfria }\}^{\text {asem }}$ \\
\hline
\end{tabular}


Nesse caso, temos "esfria" como a tradução de "melts" (derrete). "Esfria" não é sinônimo, hipônimo ou hiperônimo de "derrete", de/ssa forma, podemos dizer que há alteração semântica na tradução de "melts" por "esfria".

\begin{tabular}{|l|l|}
\hline Of thy $\{\text { happy }\}^{\text {asem }}$ strain? & Do teu canto $\left\{\right.$ em flor ${ }^{\text {asem }} ?$ \\
\hline
\end{tabular}

Nesse caso, temos "em flor" como a tradução de "happy" (feliz, alegre, contente). "Em flor" não é sinônimo, hipônimo ou hiperônimo de "feliz, alegre, contente", dessa forma, podemos dizer que há alteração semântica na tradução de "happy" por "em flor".

\section{OBSERVAÇÃO:}

A fim de evitar confusão, o anotador pode, sempre que as categorias se repetirem em um mesmo estudo de caso, numerar, com algarismos arábicos, as etiquetas na anotação: o trecho $\{\mathrm{XXXXX}\}^{\text {asem1 }}$ do original corresponderia ao trecho $\{\mathrm{XXXXX}\}^{\text {asem1 }}$ da tradução; e o trecho $\{\mathrm{XXXXX}\}^{\text {asem2 }}$ do original corresponderia ao trecho $\{\mathrm{XXXXX}\}^{\text {asem2 }}$ da tradução, por exemplo.

\section{OMISSÃO}

É a estratégia de tradução que consiste na omissão de elementos semânticos presentes em um substantivo, adjetivo, advérbio, verbo, uma oração/um período ou verso da estrofe do original. As OMISSÕES devem ser anotadas da seguinte forma: $\{\mathrm{XXXXX}\}^{\text {omi }}$, no original, mantendo sempre o termo ou o trecho a ser anotado entre duas chaves. As omissões de conjunções, artigos, preposições e pronomes isolados não serão levadas em consideração. 


\begin{tabular}{|l|l|}
\hline $\begin{array}{l}\text { Athee } \\
\{I l l\}^{\text {omi }} \text { spirits walk in white, we easly know }\end{array}$ & $\begin{array}{l}\text { Semelhança os espíritos }[\mathrm{XXXX}]^{\text {omi }} \text {, distingo: } \\
\text { By this these Angels from an evil sprite, } \\
\text { Those set our hairs, but these our flesh }\end{array}$ \\
$\begin{aligned} \text { O que o meu Anjo branco põe não é } \\
\text { O cabelo mas sim a carne em pé. }\end{aligned}$ \\
\end{tabular}

No caso em questão, há omissão de "Ill” (maus), resultando na ausência, na tradução, da distinção entre espíritos maus e anjos bons.

\section{ACRÉSCIMO}

É a estratégia de tradução que consiste no acréscimo de elementos semânticos que não estão presentes na estrofe do original, através de um substantivo, adjetivo, advérbio, verbo, uma oração/um período ou verso da tradução. Os ACRÉSCIMOS devem ser anotados da seguinte forma: $\{\mathrm{XXXXX}\}^{\text {acr }}$, na tradução, mantendo sempre o termo ou o trecho a ser anotado entre duas chaves. Os acréscimos de conjunções, artigos, preposições e pronomes isolados não serão levados em consideração.

\begin{tabular}{|l|r|}
\hline To teach thee, I am naked first; why than & $\begin{array}{r}\text { Que esperas?Estou nu... }\{\text { e as horas } \\
{[\text { se consomem }\}^{\text {acr }}}\end{array}$ \\
What needst thou have more covering & Mais cobertura tu desejas do que um \\
[then a man & [homem? \\
\hline
\end{tabular}

Nesses dois últimos versos da tradução, encontramos acréscimo de "e as horas se consomem". Tal trecho contém elementos semânticos que não encontramos no verso correspondente do original e, na verdade, em verso nenhum do original. No poema em inglês, temos a ideia de que o homem tira a roupa para ensinar a mulher a fazê-lo, sem pressa, enquanto que, na tradução, vemos o homem perdendo a paciência com a mulher, querendo que eles façam sexo logo. Acréscimos como esses ocorreram com frequência ao longo de toda a tradução em questão.

\section{Exemplo de estudo de caso}




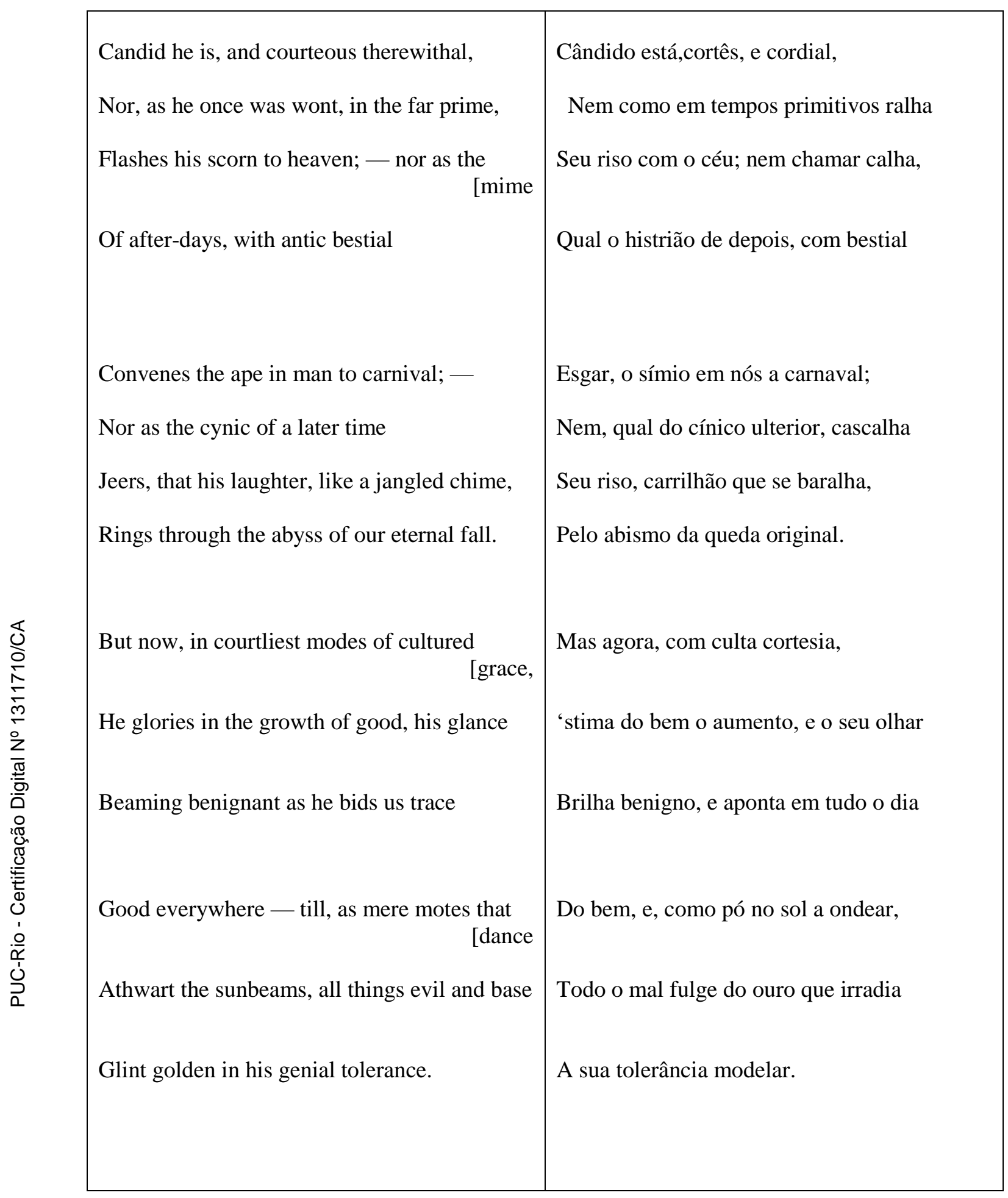

\section{Anotação}




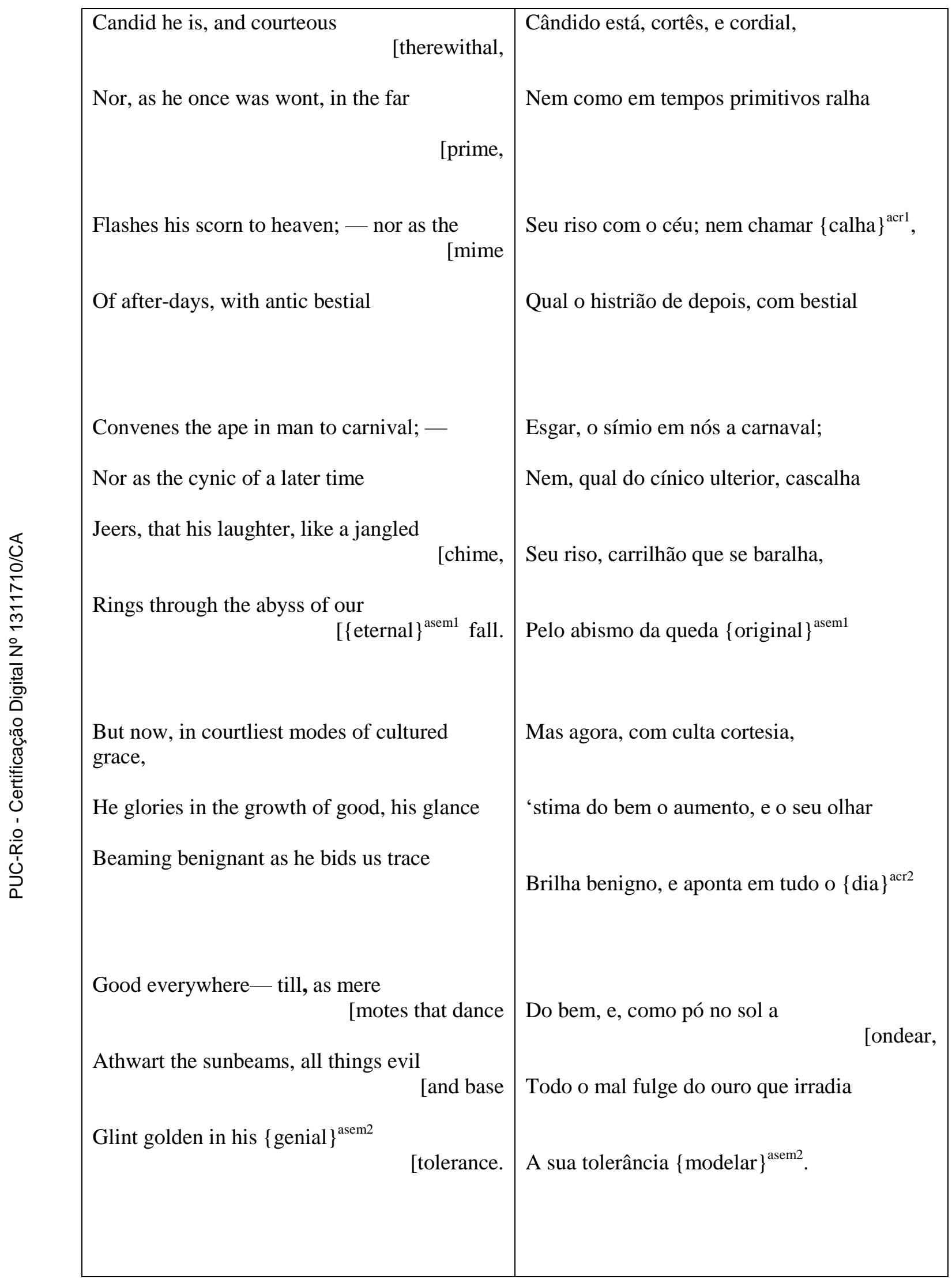


10.2.4

Guia SL4

Exemplos: poema, autor e tradutor

\begin{tabular}{|c|c|c|}
\hline POEMA & AUTOR & TRADUTOR \\
\hline To a skylark & Percy Bysshe Shelley & Fernando Pessoa \\
\hline Elegie XIX:Going to bed & John Donne & Paulo Vizioli \\
\hline Elegie XIX:Going to bed & John Donne & Augusto de Campos \\
\hline
\end{tabular}

\title{
Categorias SL4: explicações e exemplos
}

\begin{abstract}
ALTERAÇÃO SEMÂNTICA
É a estratégia que consiste em traduzir um substantivo, adjetivo, advérbio, verbo, uma oração/um período ou verso do original alterando seus elementos semânticos em um substantivo, adjetivo, advérbio, verbo, uma oração/um período ou verso correspondente da tradução. As ALTERAÇÕES SEMÂNTICAS devem ser anotadas da seguinte forma: $\{\mathrm{XXXXX}\}^{\text {asem }}$, no original e na tradução, mantendo sempre o termo ou o trecho a ser anotado entre duas chaves.

Podemos considerar que há alteração de elementos semânticos do original nos seguintes casos, em que a tradução não utiliza sinônimos, hipônimos ou hiperônimos:
\end{abstract}

\begin{tabular}{|l|l|}
\hline $\begin{array}{l}\text { Pourest thy }\left\{\text { full }^{\text {asem }}{ }^{\text {aseart }}\right. \\
\text { In profuse strains of }\end{array}$ & $\begin{array}{l}\text { Teu coração }\{\text { suave }\}^{\text {asem }} \\
\text { Derramas sem pensar, em }\end{array}$ \\
[unpremeditated art & [arte sem entrave \\
\hline
\end{tabular}


Nesse caso, temos "suave" como a tradução de "full” (pleno, repleto). "Suave" não é sinônimo, hipônimo ou hiperônimo de "pleno, repleto", dessa forma, podemos dizer que há alteração semântica na tradução de "full" por "suave".

\begin{tabular}{|l|l|}
\hline$\{\text { Melts }\}^{\text {asem }}$ around thy flight & Em torno a ti $\{\text { esfria }\}^{\text {asem }}$ \\
\hline
\end{tabular}

Nesse caso, temos "esfria" como a tradução de "melts" (derrete). "Esfria" não é sinônimo, hipônimo ou hiperônimo de "derrete", de/ssa forma, podemos dizer que há alteração semântica na tradução de "melts" por "esfria".

\begin{tabular}{|l|l|}
\hline Of thy $\{\text { happy }\}^{\text {asem }}$ strain? & Do teu canto $\{\text { em flor }\}^{\text {asem }} ?$ \\
\hline
\end{tabular}

Nesse caso, temos "em flor" como a tradução de "happy" (feliz, alegre, contente). "Em flor" não é sinônimo, hipônimo ou hiperônimo de "feliz, alegre, contente", dessa forma, podemos dizer que há alteração semântica na tradução de "happy" por "em flor".

\section{Exceções:}

As alterações semânticas que ocorrem entre conjunções, artigos, preposições, interjeições e pronomes isolados, da tradução e do original, não serão levadas em consideração.

Não consideraremos como ALTERAÇÃO SEMÂNTICA traduções que utilizem pronomes que se refiram a personagens presentes no termo ou trecho correspondente do original.

\section{OBSERVAÇÃO:}


A fim de evitar confusão, o anotador pode, sempre que as categorias se repetirem em um mesmo estudo de caso, numerar, com algarismos arábicos, as etiquetas na anotação: o trecho $\{\mathrm{XXXXX}\}^{\text {asem1 }}$ do original corresponderia ao trecho $\{\mathrm{XXXXX}\}^{\text {asem1 }}$ da tradução; e o trecho $\{\mathrm{XXXXX}\}^{\text {asem2 }}$ do original corresponderia ao trecho $\{\mathrm{XXXXX}\}^{\text {asem2 }}$ da tradução, por exemplo.

\section{OMISSÃO}

É a estratégia de tradução que consiste na omissão de elementos semânticos presentes em um substantivo, adjetivo, advérbio, verbo, uma oração/um período ou verso da estrofe do original. As OMISSÕES devem ser anotadas da seguinte forma: $\{\mathrm{XXXXX}\}^{\text {omi }}$, no original, mantendo sempre o termo ou o trecho a ser anotado entre duas chaves.

\section{Exceções:}

As omissões de conjunções, artigos, preposições, interjeições e pronomes isolados não serão levadas em consideração.

Não consideraremos como OMISSÕES traduções que utilizem elipses que subentendem elementos semânticos presentes emum substantivo, adjetivo, advérbio, verbo, uma oração/um período ou verso da estrofe do original, ou que utilizem elipses de pronomes ou pronomes que se refiram a personagens presentes na estrofe do original.

Receavd by men; Thou Angel bringst with [thee

A heaven like Mahomets Paradise; and though $\{\mathrm{Ill}\}^{\mathrm{omi}}$ spirits walk in white, we easly know By this these Angels from an evil sprite, Those set our hairs, but these our flesh [upright.
Aos homens. Tu, meu Anjo, és como o céu

De Maomé. E se no branco têm contigo Semelhança os espíritos, distingo:

O que o meu Anjo branco põe não é O cabelo mas sim a carne em pé.

No caso em questão, há omissão de "Ill" (maus), resultando na ausência, na tradução, da distinção entre espíritos maus e anjos bons. 


\section{ACRÉSCIMO}

É a estratégia de tradução que consiste no acréscimo de elementos semânticos que não estão presentes na estrofe do original, através de um substantivo, adjetivo, advérbio, verbo, uma oração/um período ou verso da tradução. Os ACRÉSCIMOS devem ser anotadosda seguinte forma: $\{\mathrm{XXXXX}\}^{\text {acr }}$, na tradução, mantendo sempre o termo ou o trecho a ser anotado entre duas chaves.

\section{Exceções:}

Os acréscimos de conjunções, artigos, preposições, interjeições e pronomes isolados não serão levados em consideração.

Não consideraremos como ACRÉSCIMO traduções que utilizem pronomes que se refiram a personagens presentes na estrofe do original.

\begin{tabular}{|l|r|}
\hline $\begin{array}{l}\text { To teach thee, I am naked first; why than } \\
\text { What needst thou have more covering } \\
\text { [then a man }\end{array}$ & $\begin{array}{r}\text { Que esperas?Estou nu... }\{\text { e as horas } \\
{[\text { se consomem }\}^{\text {acr }}}\end{array}$ \\
Mais cobertura tu desejas do que um \\
[homem?
\end{tabular}

Nesses dois últimos versos da tradução, encontramos acréscimo de "e as horas se consomem". Tal trecho contém elementos semânticos que não encontramos no verso correspondente do original e, na verdade, em verso nenhum do original. No poema em inglês, temos a ideia de que o homem tira a roupa para ensinar a mulher a fazê-lo, sem pressa, enquanto que, na tradução, vemos o homem perdendo a paciência com a mulher, querendo que eles façam sexo logo. Acréscimos como esses ocorreram com frequência ao longo de toda a tradução em questão.

\section{Exemplo de estudo de caso}

Candid he is, and courteous therewithal,

Nor, as he once was wont, in the far prime,

Flashes his scorn to heaven; - nor as the
Cândido está,cortês, e cordial,

Nem como em tempos primitivos ralha

Seu riso com o céu; nem chamar calha, 


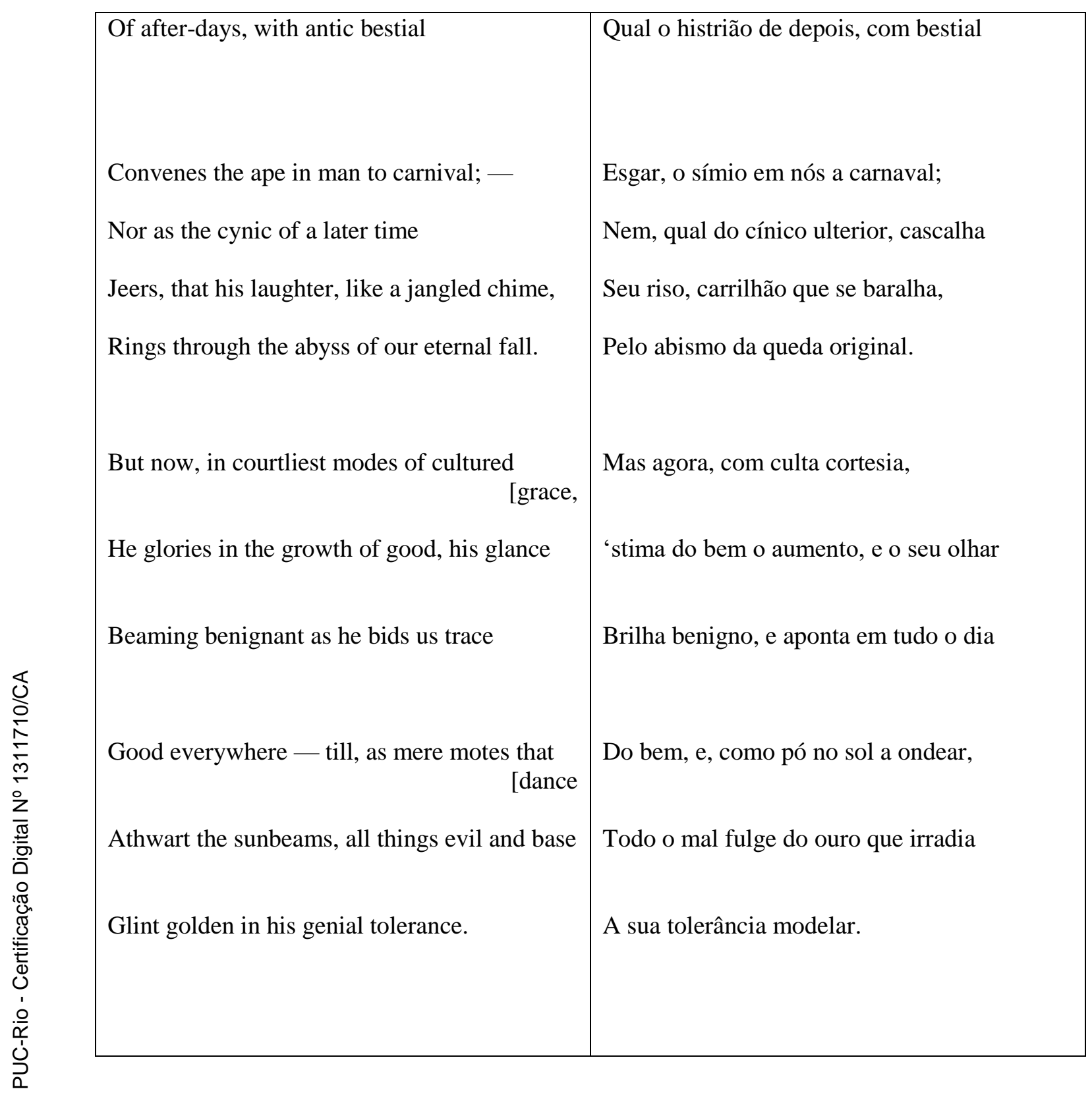

\section{Anotação}

Candid he is, and courteous [therewithal,

Cândido está, cortês, e cordial,

Nor, as he once was wont, in the far

Nem como em tempos primitivos ralha [prime, 


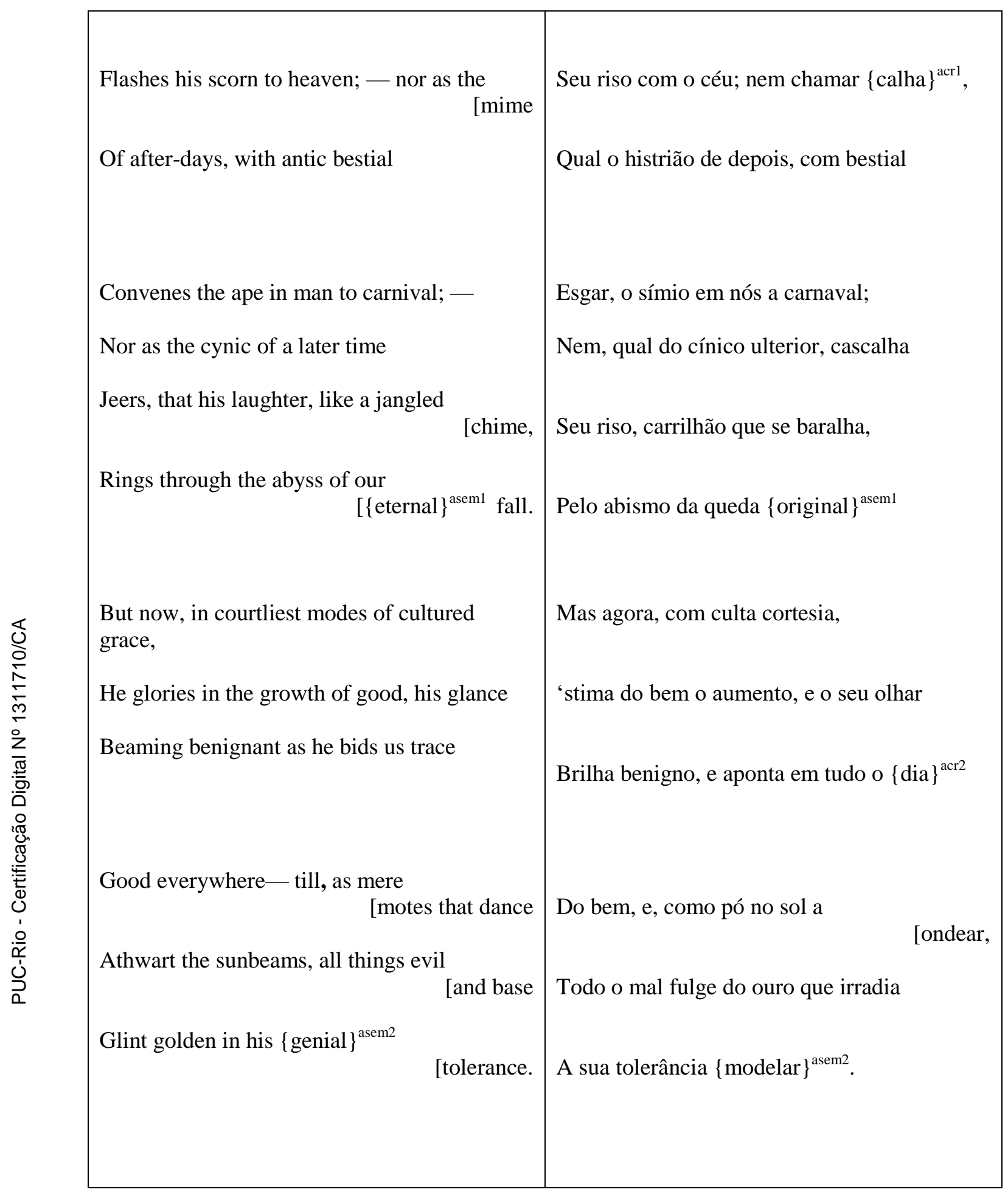


10.2 .5

\section{Guia F}

Exemplos: poema, autor e tradutor

\begin{tabular}{|c|c|c|}
\hline POEMA & AUTOR & TRADUTOR \\
\hline Catarina to Camoens & Elizabeth Barrett Browning & Fernando Pessoa \\
\hline To a skylark & Percy Bysshe Shelley & Fernando Pessoa \\
\hline $\begin{array}{c}\text { The last metamorphosis of } \\
\text { Mephistopheles }\end{array}$ & Frank Marzials & Fernando Pessoa \\
\hline 96 & Emily Dickinson & Ana Luísa Amaral \\
\hline
\end{tabular}

Categorias F para anotação de estudos de caso quanto ao nível formal: explicações e exemplos

RIMAS: poemas em inglês e português

Rima é a repetição de sons ao fim de dois ou mais versos.Devem ser anotadas com letras, por exemplo, $a$ para a primeira rima do poema; $b$, para a segunda; e assim por diante. Versos sem rimas devem ser anotados com $x$. As RIMAS devem ser anotadas em itálico, em minúsculo e na primeira coluna à direita do poema.

Exemplos:

Rings through the abyss of our eternal fall. $a$

Receios e ilusões que não sabia amar: $m$ 
SÍMBOLOS PARA ESCANSÃO : poemas em inglês e português

Escansão é a ação ou resultado de escandir, de decompor um verso em seus componentes métricos. Para isso, é possível utilizar diferentes símbolos, que podem corresponder, por exemplo, a acentos primários; acentos secundários, separadores de pés (somente em poemas em inglês); pausas; e sílabas átonas. Devem ser utilizados os seguintes símbolos nas escansões:

acento primário $=/$

acento secundário $=1$

separador de pés (somente nos poemas em inglês) $=\mid$

pausa $=\|$

sílaba átona $=$ -

PÉS : poemas em inglês

O pé é a unidade rítmica mínima do verso em inglês. Os mais comuns são:

Jambo: - / (sílaba átona + sílaba acentuada);

Troqueu: / - (sílaba acentuada+ sílabas átona);

Anapesto: - - / (sílaba átona + sílaba átona + sílaba acentuada);

Espondeu: / / (sílaba acentuada+ sílabas acentuada); e

Pirríquio: - - (sílaba átona + sílaba átona)

Jambo, troqueu, espondeu e pirríquio são pés binários (duas sílabas); e o anapesto é um pé ternário (três sílabas).

Escansão de um verso em inglês: 


$$
1 \quad-|-1|-1|-||-1|
$$

Jeers, that his laughter, like a jangled chime,

Escansão mais detalhada:

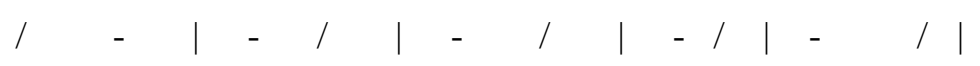

Jeers, that --- his laugh ----- ter, like ----- a jan ----gled chime,

Aqui, temos 5 pés binários, separados por esse símbolo: | O primeiro pé do verso chamamos de troqueu( / - = sílaba acentuada + sílaba átona), e os outros quatro chamamos de jambo ( - / = sílaba átona + sílaba acentuada).

Os pés devem ser anotados com a primeira letra de seu nome. A letra deve estar em maiúsculo.

$\mathrm{Jambo}=\mathrm{J}$

Troqueu $=\mathrm{T}$

Anapesto $=\mathrm{A}$

Espondeu $=\mathrm{E}$

Pirríquio $=\mathrm{P}$

A anotação dos pés nos versos deve ser feita sempre na coluna ao lado direito daquela da RIMA. Exemplos:

$$
\text { / - - - - /|- /|- / - / }
$$

Rings through the abyss of our eternal fall. $\quad a$ T-A-J-J-J 


$$
/-|/-| /-\mid
$$

Like a Poet hidden $\quad p \quad$ T-T-T

$$
1 \quad-1 /-1 / 1-1 / 1
$$

While my spirit leans and reaches $r$ T-T-T-T

$$
-1|-||-1|-1|-1|-1 \mid
$$

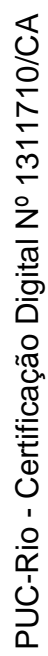
To sympathy with hopes and fears it heeded not:
$n$ J-J-J-J-J-J

SÍLABAS :poemas em português

A sílaba é a unidade rítmica mínima do verso em português.

Escansão de um verso em português:

Seu riso, carrilhão que se baralha,

Escansão mais detalhada:

Seu--- ri---so,--- car---ri---lhão --- que ---- se ----ba --- ra ---lha, 
Aqui, temos um verso com 10 sílabas: contamos as sílabas até a última sílaba com acento primário do verso.

A anotação das sílabas deve ser feita com algarismos arábicos, e deve seguir a contagem das sílabas com acentos primários, secundários e as sílabas átonas.

A última sílaba do verso a ser levada em conta na contagem será a última com acento primário.

O número correspondente à sílaba com acento secundário ficará entre parênteses.

A anotação das sílabas deve ser feita na coluna ao lado direito daquela da RIMA.

Exemplos:

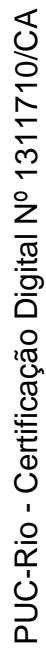

$$
1-\quad 1-1--1
$$

Cândido está, cortês, e cordial, $a$ 1-4-6-10

$-1--1-1-1-1$

Receios e ilusões que não sabia amar: $\quad m$ 2-6-8-10-12

- I - I

Poeta, vem c 2-4

\section{Exemplos:}


$\operatorname{Ex}^{29}$ :

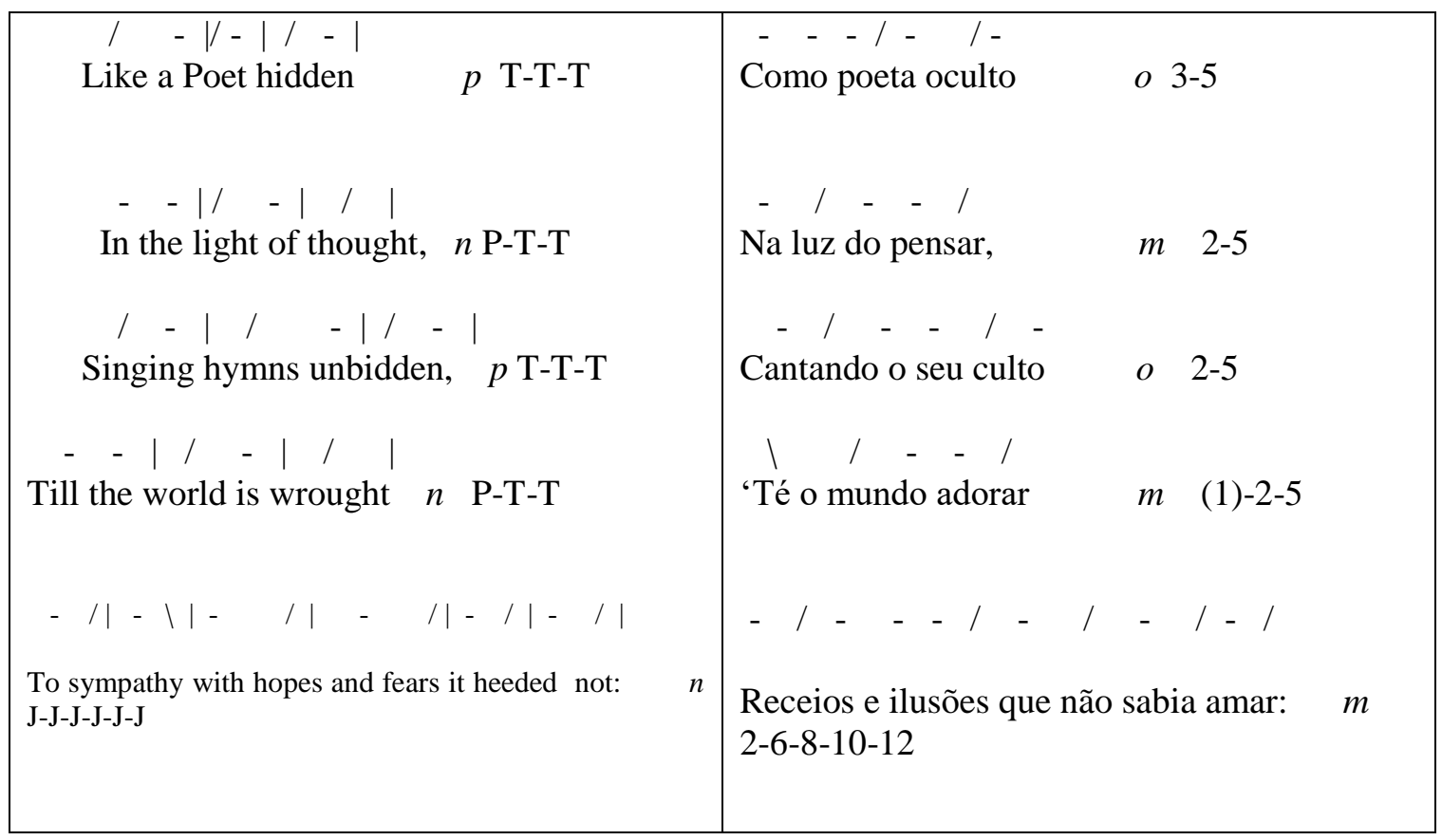

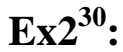

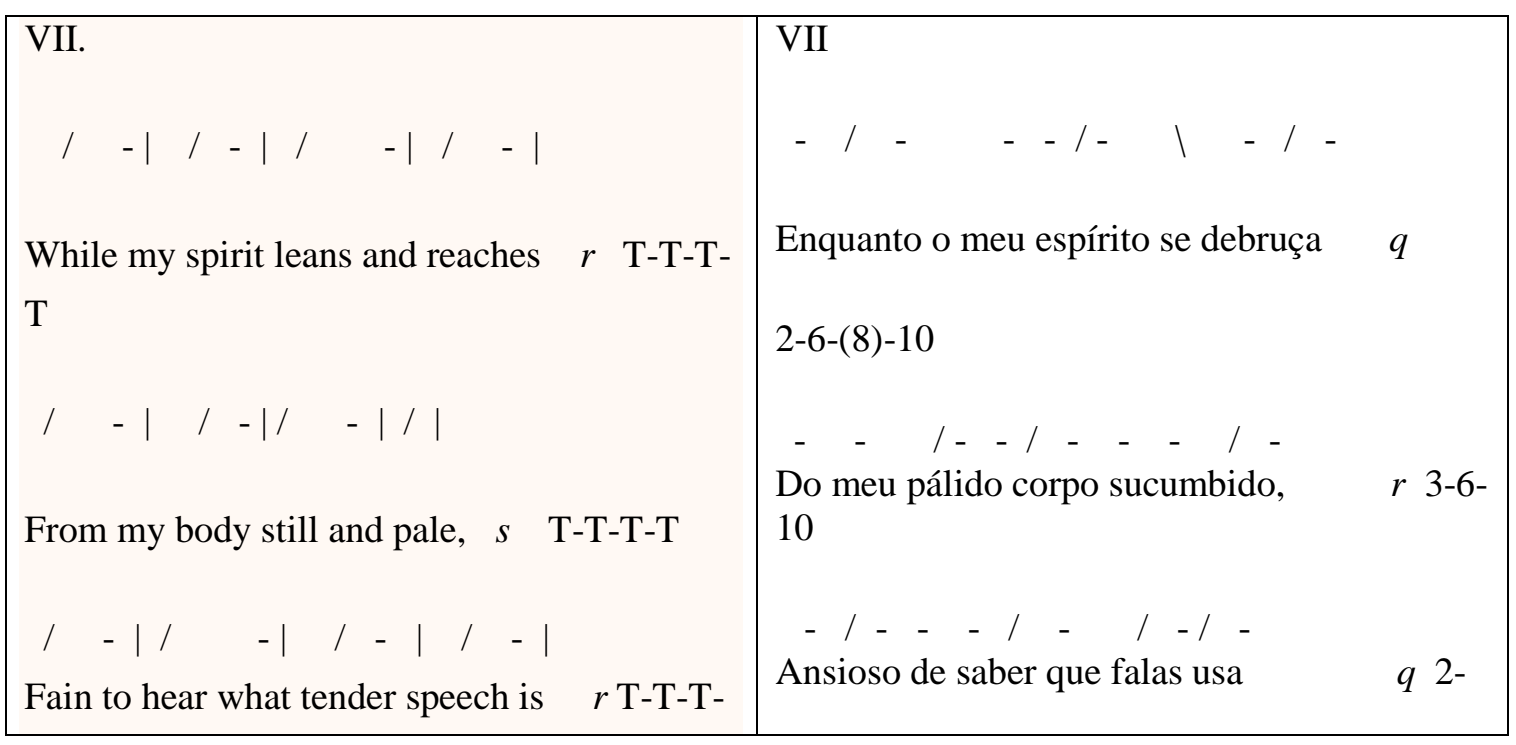

\footnotetext{
${ }^{29}$ As escansões completas, do original e da tradução, estão disponíveis no capítulo 2 da minha dissertação: http://www2.dbd.puc-rio.br/pergamum/tesesabertas/1112728_2012_cap_2.pdf

${ }^{30}$ As escansões completas, do original e da tradução, estão disponíveis no capítulo 3 da minha dissertação: http://www2.dbd.puc-rio.br/pergamum/tesesabertas/1112728_2012_cap_3.pdf
} 


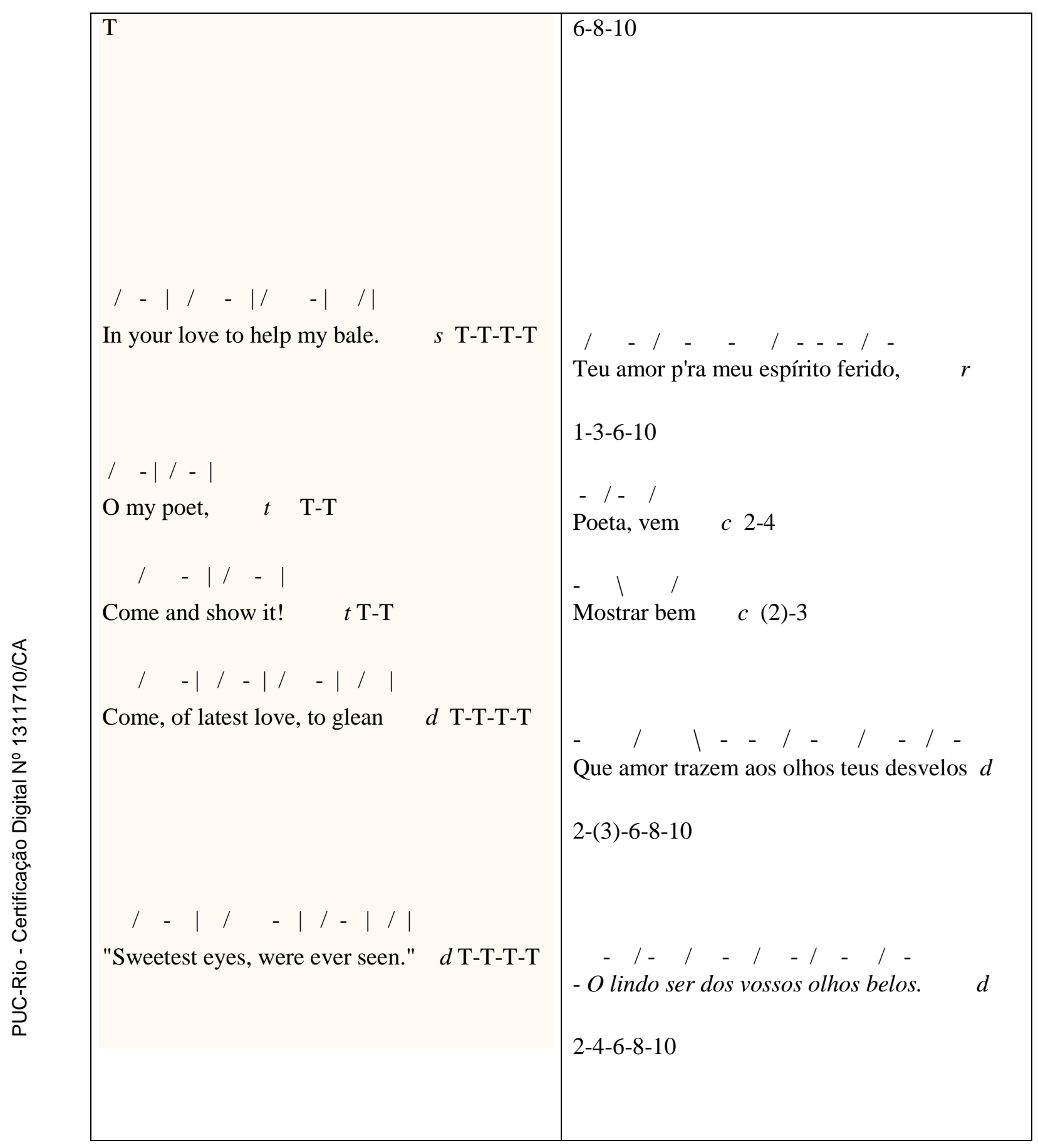

\section{Ex3:}

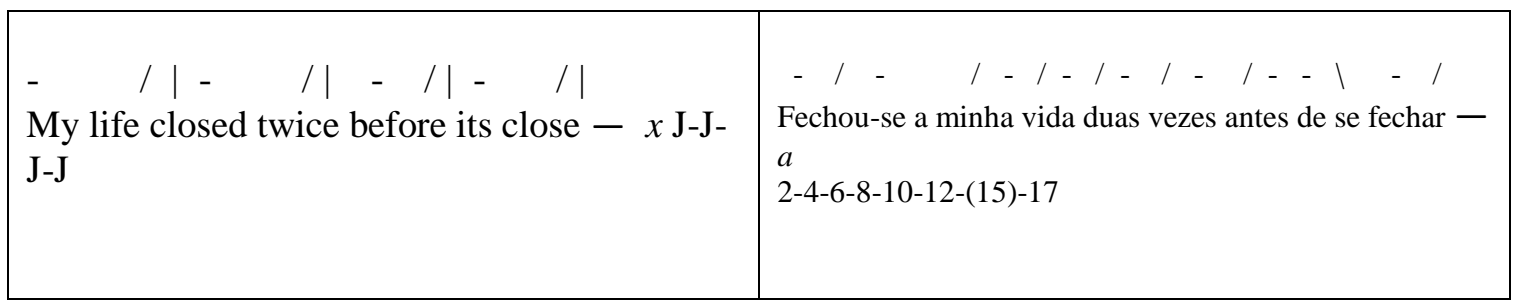




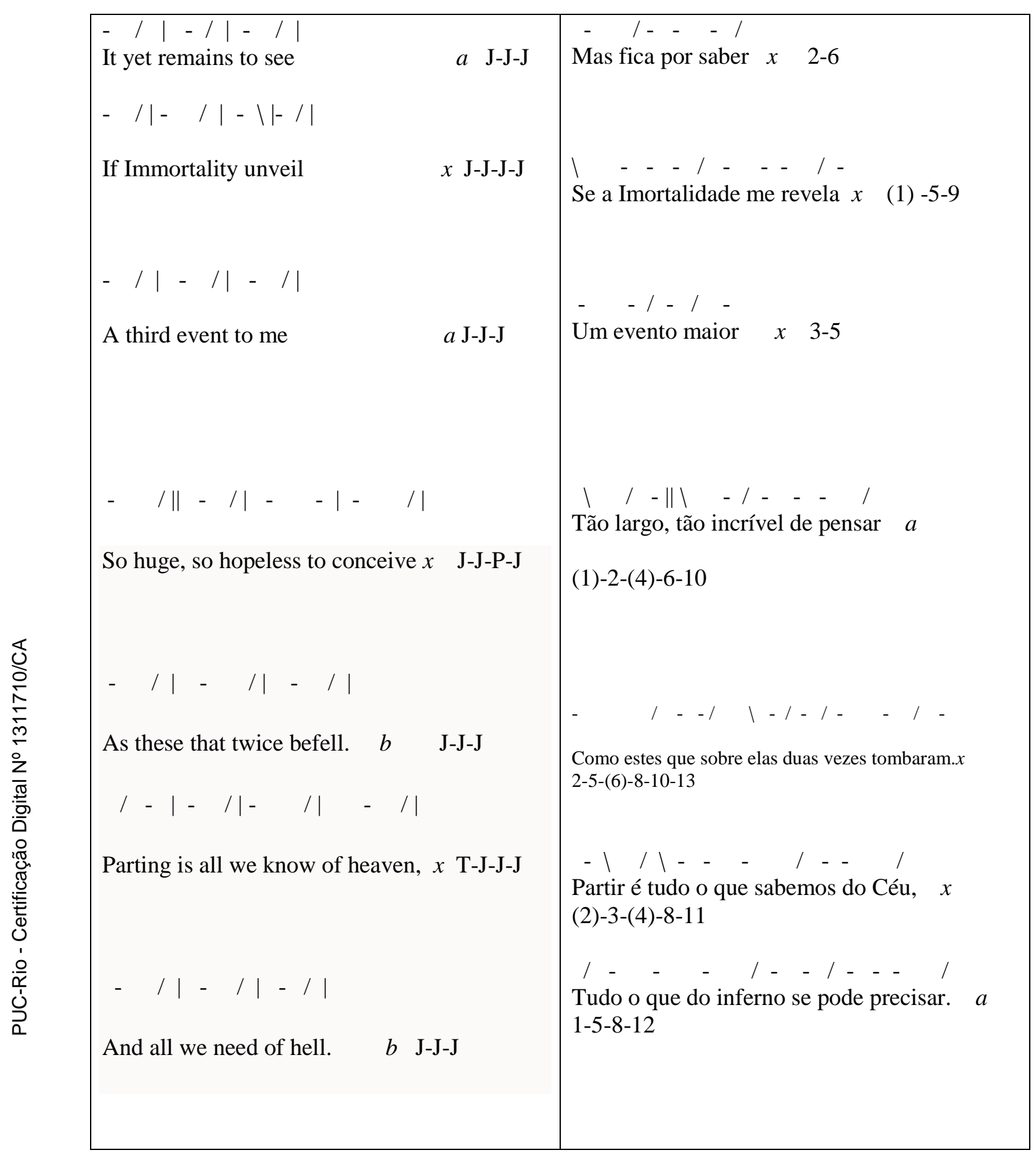

\section{Exemplo de estudo de caso}

Candid he is, and courteous therewithal,

Nor, as he once was wont, in the far prime,

Flashes his scorn to heaven; - nor as the
Cândido está,cortês, e cordial,

Nem como em tempos primitivos ralha

Seu riso com o céu; nem chamar calha, 


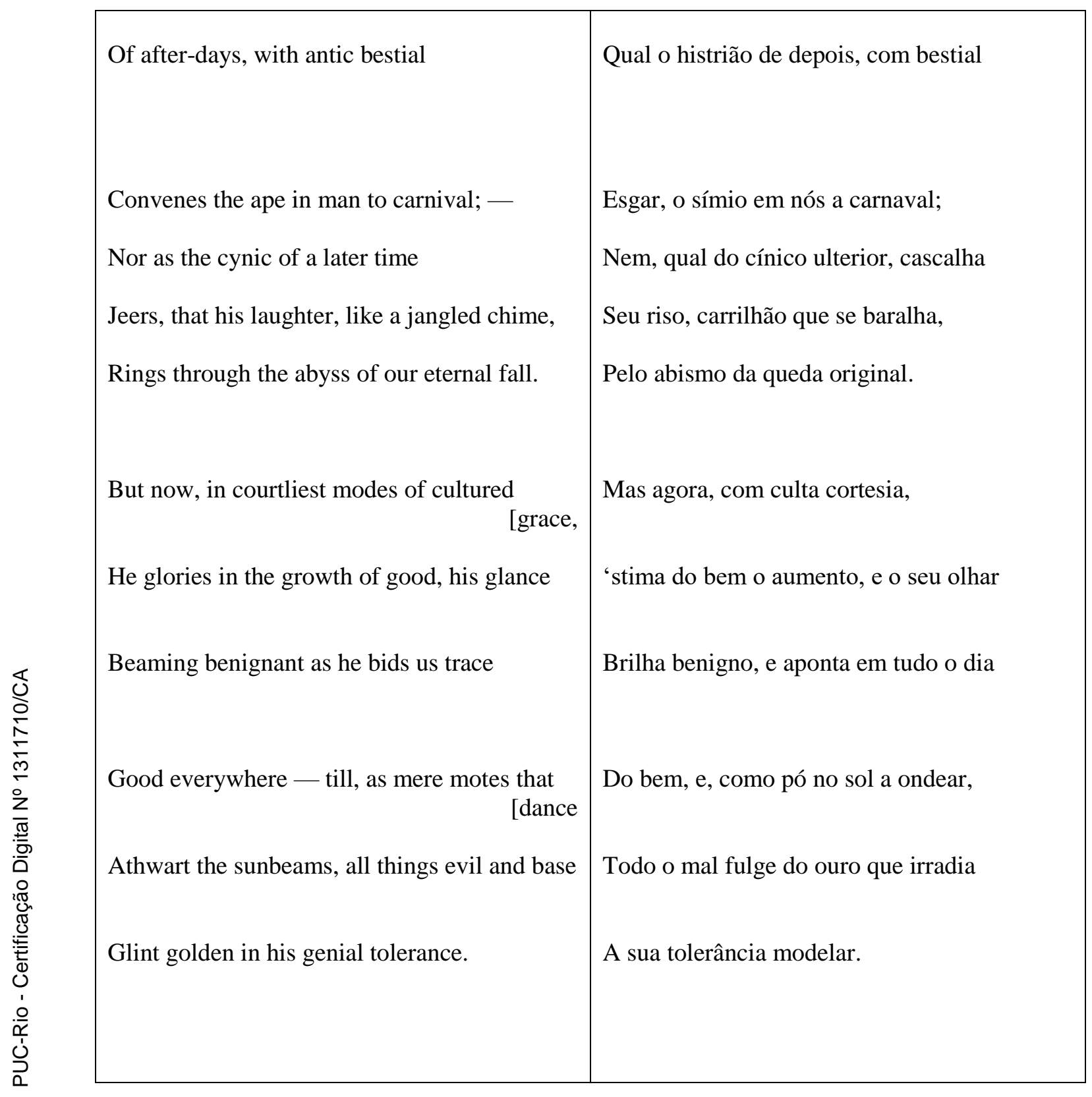

\section{Anotação}

\begin{tabular}{|c|c|}
\hline $\begin{array}{l}/ \quad-|-/|-|/|-1|-| / \mid \\
\text { Candid he is, and courteous therewithal, } a \\
\text { T-J-J-J-J }\end{array}$ & $\begin{array}{l}/-\quad / \quad / \quad-\quad-/ \\
\text { Cândido está, cortês, e cordial, } a \\
1-4-6-10\end{array}$ \\
\hline $\begin{array}{l}/ \quad-|-||-| /|--| /|/| \\
\text { Nor, as he once was wont, in the far prime, } \\
b \text { T-J-J-P-E }\end{array}$ & $\begin{array}{l}/ \quad-\quad-\quad /---/-I- \\
\text { Nem como em tempos primitivos ralha } \\
1-4-8-10\end{array}$ \\
\hline $\begin{array}{l}|-|-||-|||| l-|-| / \mid \\
\text { Flashes his scorn to heaven; }- \text { nor as the mime } b \text { T- }\end{array}$ & -1|| 1 \\
\hline
\end{tabular}




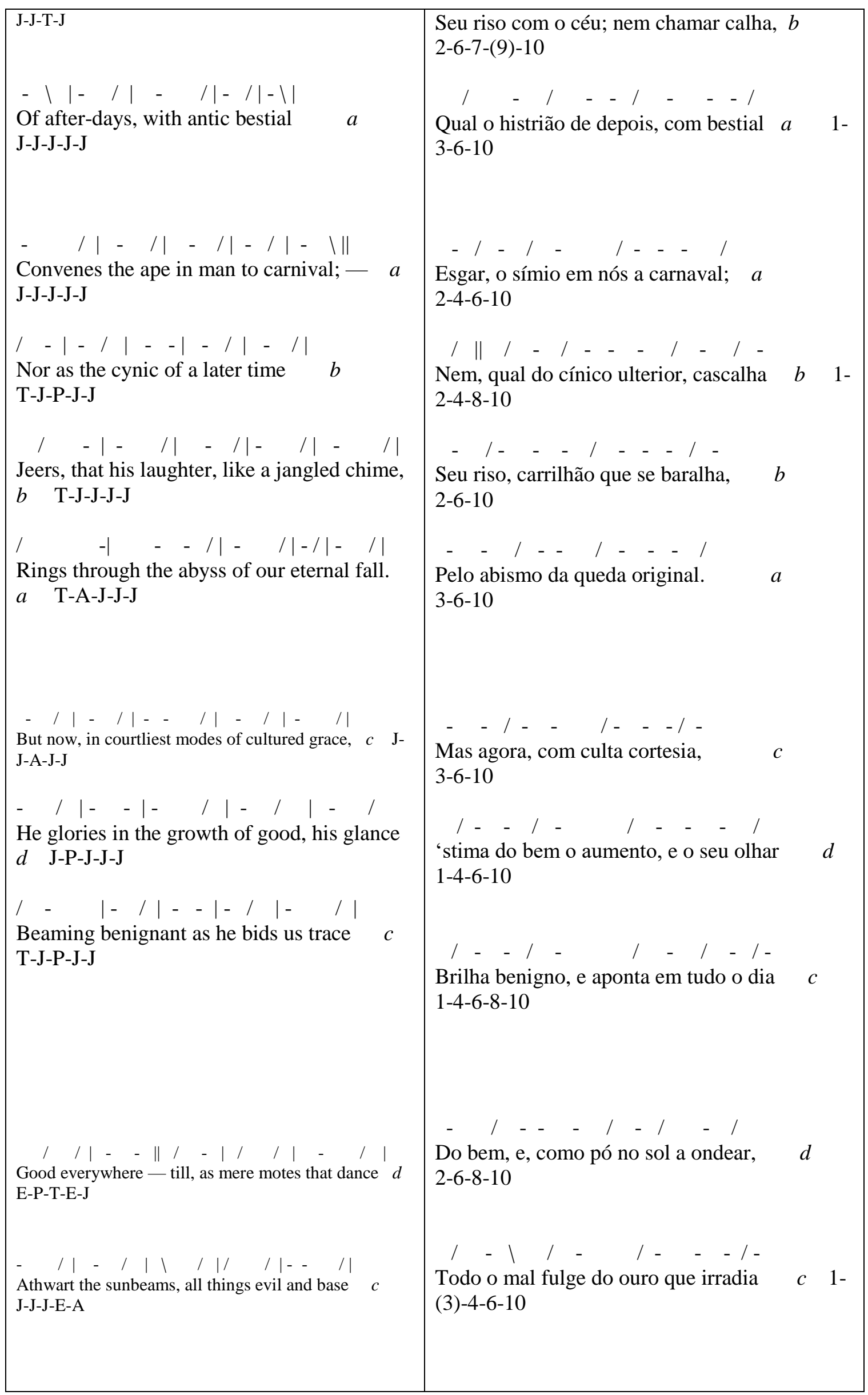




\begin{tabular}{|c|c|}
\hline $\begin{array}{l}\text { / / }|--|-/|-/|-|| \\
\text { Glint golden in his genial tolerance. } d \\
\text { E-P-J-J-J }\end{array}$ & $\begin{array}{l}-/---/---1 \\
\text { A sua tolerância modelar. } \\
6-10\end{array}$ \\
\hline
\end{tabular}

10.2.6

Guia RS

Exemplos: poema, autor e tradutor

\begin{tabular}{|c|c|c|}
\hline POEMA & AUTOR & TRADUTOR \\
\hline Catarina to Camoens & Elizabeth Barrett Browning & Fernando Pessoa \\
\hline To a skylark & Percy Bysshe Shelley & Fernando Pessoa \\
\hline $\begin{array}{c}\text { The last metamorphosis of } \\
\text { Mephistopheles }\end{array}$ & Frank Marzials & Fernando Pessoa \\
\hline Howl & Allen Ginsberg & Claudio Willer \\
\hline Violões que choram & João Cruz e Sousa & - \\
\hline Metric figure & William Carlos Williams & - \\
\hline Song of myself & Walt Whitman & José Agostinho Baptista \\
\hline
\end{tabular}

Categorias RS paraanotação dos estudos de caso quanto ao plano de recursos sonoros

\section{ALITERAÇÕES}

As aliterações consistem na repetição de consoantes, principalmente no início de palavras ou em sílabas acentuadas de palavras presentes em um mesmo verso ou em versos consecutivos. Em inglês, as aliterações também podem ocorrer entre semivogais, nas condições já descritas aqui. As ALITERAÇÕES devem ser anotadas da seguinte forma: $\{\mathrm{X}\}^{\text {ali }}$, mantendo sempre a representação gráfica da aliteração entre duas chaves.

\section{Obs1:}


Como raramente encontramos aliterações entre semivogais em português, levaremos em consideração somente as aliterações entre semivogais em inglês.

\section{Obs2:}

Em alguns casos, é possível encontrarmos consoantes aliterantes em sílabas átonas, como nos exemplos a seguir:

$\{\mathrm{V}\}^{\text {ali }}$ ozes $\{\mathrm{v}\}^{\text {ali }}$ eladas, $\{\mathrm{v}\}^{\text {ali }}$ eludosas $\{\mathrm{v}\}^{\text {ali }}$ ozes, $\{\mathrm{V}\}^{\text {ali }}$ olúpias dos $\{\mathrm{v}\}^{\text {ali }}$ iolões, $\{\mathrm{v}\}^{\text {ali }}$ ozes $\{\mathrm{v}\}^{\text {ali }}$ eladas, $\{\mathrm{V}\}^{\text {ali }}$ agam nos $\{\mathrm{v}\}^{\text {ali }}$ elhos $\{\mathrm{v}\}^{\text {ali }}$ órtices $\{\mathrm{v}\}^{\text {ali }}$ elozes Dos $\{v\}^{\text {ali }}$ entos, $\{v\}^{\text {ali }} i\{v\}^{\text {ali }}$ as, $\{v\}^{\text {ali }}$ as, $\{v\}^{\text {ali }}$ ulcanizadas.

Aqui, todas as consoantes $/ \mathrm{v} /$ aliteram, inclusive aquela presente na segunda sílaba de "vivas", que é átona. A aliteração em /v/ é tão marcada que se justifica levar em conta até mesmo as ocorrências do fonema em sílabas átonas.

$\mathrm{d}\{\mathrm{r}\}^{\text {ali }}$ agging themselves $\mathrm{th}\{\mathrm{r}\}^{\text {ali }}$ ough the ne $\{\mathrm{gr}\}^{\text {ali }} \mathrm{ost}\{\mathrm{r}\}^{\text {ali }}$ eets at dawn looking for an

$$
\operatorname{an}\{\mathrm{gr}\}^{\mathrm{ali}} \mathrm{y} \text { fix, }[\ldots]
$$

Aqui temos aliteração em /r/ entre as sílabas tônicas de "dragging", "through" e "streets"; e aliteração em /gr/ entre as sílabas átonas de "negro" e "angry". A aliteração em /r/ é tão marcada que se justifica levar em conta até mesmo as ocorrências do fonema em sílabas átonas.

\section{ASSONÂNCIAS}

As assonâncias consistem na repetição de vogais, principalmente no início de palavras e em sílabas acentuadas de palavras presentes em um mesmo verso ou em versos consecutivos. As ASSONÂNCIAS devem ser anotadasda seguinte forma: $\{X\}^{\text {asson }}$, mantendo sempre a representação gráfica da assonância entre duas chaves.

\section{Obs3:}


Em alguns casos, podemos observar assonâncias em sílabas átonas, como nos seguintes exemplos:

Vozes veladas, veludosas vozes,

Volúpias dos violões, vozes veladas,

Vagam nos velhos vórtices velozes

Dos ventos, vivas, $v\{\tilde{a}\}{ }^{\text {asson }} \mathrm{s}$, vulc $\{\mathrm{a}\}{ }^{\text {asson }}$ nizadas.

Aqui, podemos notar assonância em /aN/ entre "vãs" e "vulcanizadas", muito embora a segunda sílaba de "vulcanizadas" seja átona. A assonância em /aN/ é tão marcada que se justifica levar em conta até mesmo as ocorrências do fonema em sílabas átonas.

\begin{tabular}{|llll} 
e $\quad \operatorname{vir}\{\text { am }\}^{\text {asson }} \quad\{\text { an }\}^{\text {asson }}$ jos & maomet $\{a\}^{\text {asson }}{ }^{\text {nos }} \quad c\{a m\}^{\text {asson }}$ bale $\{\text { an }\}^{\text {asson }}$ do \\
iluminados
\end{tabular}

Aqui temos assonância em /aN/ entre "viram", "anjos", "maometanos" e "cambaleando". Apesar das vogais da última sílaba de "viram" e da primeira de "cambaleando" serem átonas, elas fazem assonância com as vogais tônicas de "anjos", "maometanos" e "cambaleando". A assonância em /aN/ é tão marcada que se justifica levar em conta até mesmo as ocorrências do fonema em sílabas átonas.

$\mathrm{Sw}\{\mathrm{i}\}^{\text {asson }} \mathrm{mm}\{\mathrm{i}\}^{\text {asson }} \mathrm{ng}\{\mathrm{i}\}^{\text {asson }} \mathrm{n}$ the $\mathrm{r}\{\mathrm{i}\}^{\text {asson }}$ ver;

Nesse caso, podemos observar assonância em /I/ entre "Swimming", “in", "river". Apesar das vogais da última sílaba de "Swimming" e a de "in" serem átonas, elas fazem assonância com as vogais tônicas de "Swimming" e de "river". A assonância em /I/ é tão marcada que se justifica levar em conta até mesmo as ocorrências do fonema em sílabas átonas.

\section{RIMAS INTERNAS}


As rimas internas consistem na repetição da parte final da palavra, a partir da última vogal tônica, em palavras diferentes em uma mesma estrofe.Não consideramos como rima interna as rimas que ocorrem somente entre palavras em fim de verso. Em inglês, há ainda a possibilidade da rima interna átona, em que a última sílaba da palavra, quando átona, repete-se, nas condições já descritas aqui. As RIMAS INTERNAS devem ser anotadasda seguinte forma: $\{X\}^{\text {ri }}$, mantendo sempre a representação gráfica da rima interna entre duas chaves.

\section{REPETIÇÕES DIVERSAS}

As repetições diversas consistem na repetição de palavras ou trechos no início, no finalou em qualquer outro lugar dos versos, consecutivos ou não, em uma mesma estrofe. Elas também consistem em repetições de palavras ou trechos em estrofes consecutivas, ou intercaladas. As repetições diversas também consistem na repetição de um radical em palavras diferentes em uma mesma estrofe. As REPETIÇÕES DIVERSAS devem ser anotadas da seguinte forma: $\{X\}^{\text {repd }}$, mantendo sempre o termo ou o trecho que se repete entre duas chaves.

\section{Exemplos:}

Ex1:

Like a high-born maiden

In a palace tower,

$\{\mathrm{S}\}^{\text {ali }}$ oothing her $\{1\}^{\text {ali }}$ ove- $\{1\}^{\text {ali }}$ aden $\{\mathrm{S}\}^{\text {ali }}$ ou $\{1\}^{\text {ali }}$ in $\{\mathrm{S}\}^{\text {ali }}$ ecret hour With music $\{\mathrm{S}\}^{\text {ali }}$ weet as $\{1\}^{\text {ali }}$ ove, which [overf $\{1\}{ }^{\text {ali }}$ ows her bower:
Qual nobre donzela

Numa torre antiga,

Colmando a alma, bela

De $a\{m\}^{\text {ali }}$ ar, com a $\{\mathrm{m}\}^{\text {ali }}$ iga

$\{\mathrm{m}\}^{\text {ali }}$ úsica como o $\mathrm{a}\{\mathrm{m}\}^{\text {ali }}$ or, que enche a

[torre que a abriga:

Ex2: 


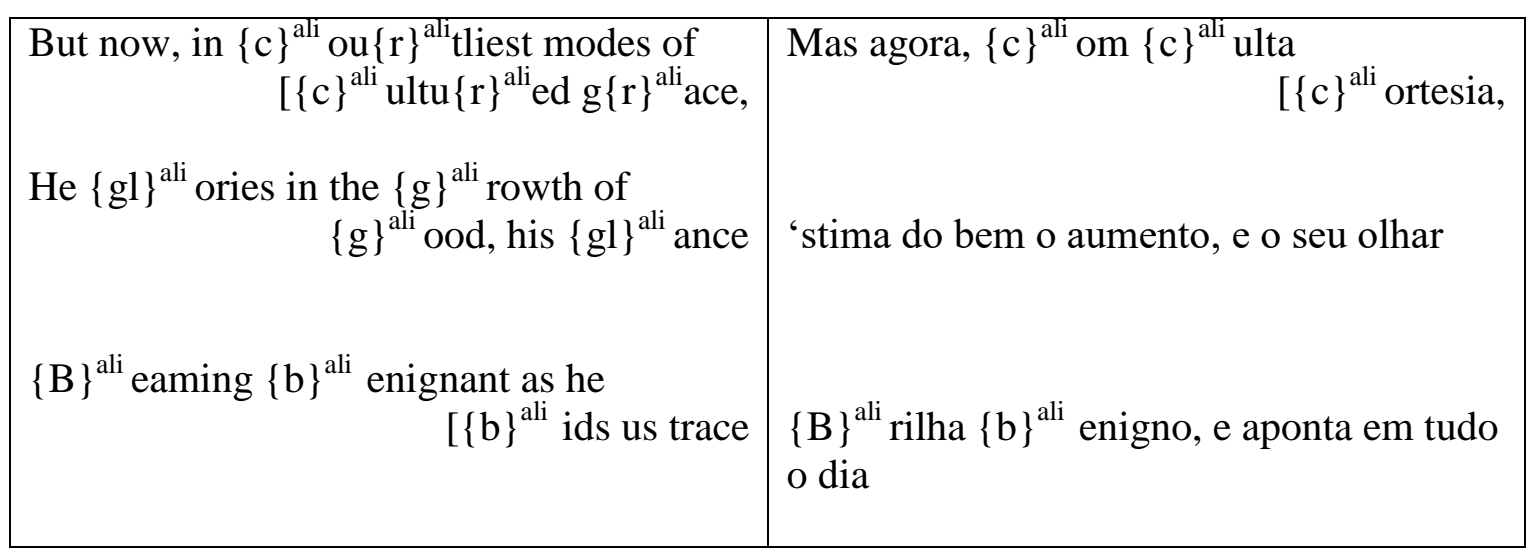

Ex3:

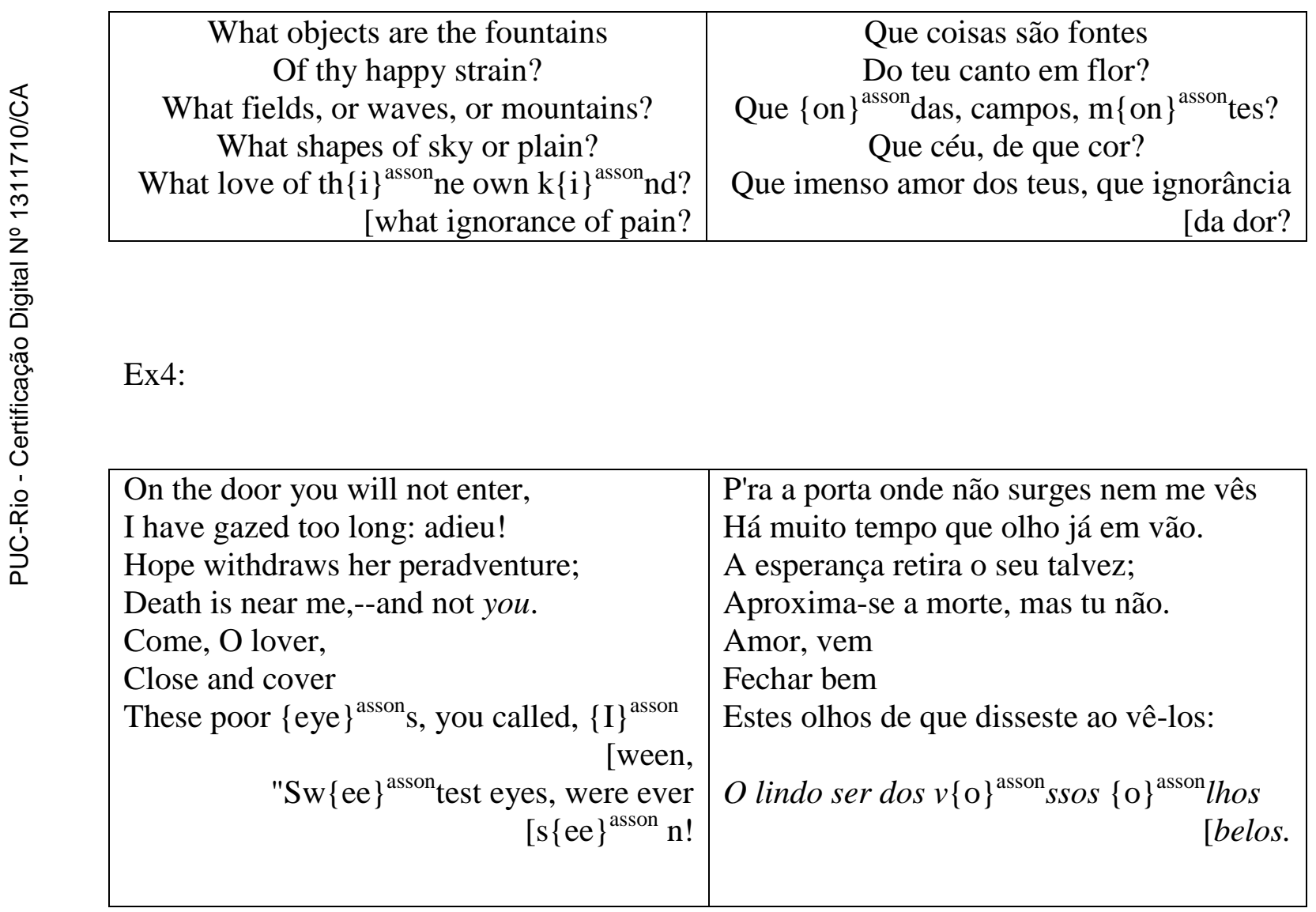

Ex5:

Higher still and higher

From the earth thou springest, Like a cloud of fire;
Alto, e inda mais logo,

Vai teu vôo aéreo;

Qual nuvem de fogo 
The blue deep thou wingest, And sing $\{\text { ing }\}^{\text {ri }}$ still dost soar, and [soar $\{\text { ing }\}^{\text {ri }}$ ever singest.
Pelo azul sidéreo

Voas cant $\{\text { ando }\}^{\text {ri }}$, e vo $\{\text { ando }\}^{\text {ri }}$ alças teu

[voo etéreo.

Ex6:

\begin{tabular}{|c|c|}
\hline Teach me half the gladness & Soubesse eu o que goza \\
That thy brain must know; & Tua alma, e tal fora \\
Such harmonious madness & Minha harmoniosa \\
From my lips would flow, & Lírica loucura \\
The world should $\{\text { listen }\}^{\text {repd }}$ then - as I & Que o mundo $\{\text { escut }\}^{\text {repd }}$ aria como \\
{$\left[\right.$ am $\{\text { listen }\}^{\text {repd. }}$ ing now. } & {$[\text { escut }\}^{\text {repd }}$ o agora. } \\
\end{tabular}

Ex7:

\begin{tabular}{|c|c|}
\hline $\begin{array}{c}\{\text { Better than all }\}^{\text {repd }} \text { measures } \\
\text { Of delightful sound, } \\
\{\text { Better than all }\}^{\text {repd }} \text { treasures } \\
\text { That in books are found, } \\
\text { Thy skill to poet were, thou scorner of the } \\
\text { ground! }\end{array}$ & $\begin{array}{c}\text { Mais que todo o ouro } \\
\{\text { Que }\}^{\text {repd }} \text { um canto descerra } \\
\{\text { Que }\}^{\text {repd }} \text { todo o tesouro } \\
\{\text { Que }\}^{\text {repd }} \text { em livros se encerra, } \\
\text { Teu canto ao poeta val', desdenhador da } \\
\text { terra! }\end{array}$ \\
\hline
\end{tabular}

Ex 8:

\begin{tabular}{|c|c|}
\hline $\begin{array}{c}\text { Like a rose embowered } \\
\text { In its own green leaves, } \\
\text { By }\{\mathrm{w}\}^{\text {ali }} \text { arm }\{\mathrm{w}\}^{\text {ali }} \text { inds deflo }\{\mathrm{w}\}^{\text {ali }} \text { ered, } \\
\text { Till the scent it gives } \\
\text { Makes faint with too much sweet those } \\
\text { [heavy-wingèd thieves: }\end{array}$ & $\begin{array}{l}\text { Qual } r\{\mathrm{o}\}^{\text {asson }} \text { sa que } \mathrm{m}\{\mathrm{o}\}^{\text {asson }} \text { ra } \\
\text { No cálice verde, } \\
\text { E o vento desflora, } \\
\text { E o aroma que cede } \\
\text { Embriaga o alado roubador que a } \\
\text { [perde: }\end{array}$ \\
\hline
\end{tabular}

Ex9:

Nor, as he $\{0\}^{\text {ali }}$ nce $\{w\}^{\text {ali }}$ as $\{w\}^{\text {ali }}$ ont, in the far prime,
$\mathrm{N}\{\mathrm{em}\}{ }^{\text {asson }}$ como em $\mathrm{t}\{\mathrm{em}\}{ }^{\text {asson }}$ pos primitivos ralha 
Ex10:

$\{\mathrm{N}\}^{\text {ali }}$ one obey'd the $\operatorname{co}\{\mathrm{mm}\}^{\text {ali }}$ and to $\quad$ Ninguém acatou a ordem de ajoelhar-se, $\left[\{\mathrm{kn}\}{ }^{\text {ali }}\right.$ eel, $\{\mathrm{S}\}^{\text {ali }} \mathrm{o}\{\mathrm{m}\}^{\text {ali }}$ e $\{\mathrm{m}\}^{\text {ali }}$ ade a [Alguns tentaram desesperadamente $\{\mathrm{m}\}^{\text {ali }}$ ad and helpless rush, $\{\mathrm{S}\}^{\text {ali }} \mathrm{o}\{\mathrm{m}\}^{\text {ali }} \mathrm{e}$ fug $\{\mathrm{i}\}^{\text {asson }} \mathrm{r}$, outros permaneceram $\mathrm{r}\{\hat{1}\}^{\text {asson }}$ $\{\mathrm{st}\}^{\text {ali }}$ ood $\{\mathrm{st}\}^{\text {ali }}$ tark and $\{\mathrm{st}\}{ }^{\text {ali }}$ raight, gidos e $\mathrm{f}\{\mathrm{i}\}{ }^{\text {asson }} \mathrm{rmes}$,

A $\{f\}^{\text {ali }}$ ew $\{f\}^{\text {ali }}$ ell at once, shot in the $\left[\{t\}^{\text {ali }}\right.$ emple or heart, the $\{1\}^{\text {ali }}$ iving and dead $\{1\}^{\text {ali }}$ ay $\{t\}^{\text {ali }}$ ogether,

Alguns tombaram imediatamente,

[ating $\{i\}^{\text {asson }}$ dos na fronte ou no coração, juntos ficaram os $\mathrm{v}\{\mathrm{i}\}^{\text {asson }}$ vos e os mortos,

The $\{m\}^{\text {ali }}$ ai $\{m\}^{\text {ali }}$ 'd and $\{m\}^{\text {ali }}$ angled

Os fer $\{\mathrm{i}\}^{\text {asson }}$ dos e mutilados

$\left[\{d\}^{\text {ali }}\right.$ ug in the $\{d\}^{\text {ali }}$ irt, the new-comers [afundaram-se na lama, e a $\{\mathrm{i}\}^{\text {asson }}$ nda os saw $\{\text { th }\}^{\text {ali }}$ em $\{\text { th }\}^{\text {ali }}$ ere, $\mathrm{v}\{\mathrm{i}\}^{\text {asson }}$ ram os novatos,

Ex 11:

\begin{tabular}{|l|l}
\hline From my body sti $\{11\}^{\text {ali }}$ and $\mathrm{pa}\{1\}^{\text {ali }} \mathrm{e}$ & Do meu pálido corpo sucumbido
\end{tabular}

\section{Sobreposição de categorias}

Pode haver sobreposição de categorias em uma mesma palavra. As sobreposições devem ser anotadas da seguinte maneira: $\left\{\mathrm{XX}\{\mathrm{X}\}^{\mathrm{y}} \mathrm{XX}\right\}^{\mathrm{z}}$, onde "y" é um recurso sonoro e "z" é um outro, mantendo sempre as representações gráficas dos recursos sonoros entre duas chaves. Vejamos um exemplo:

Ex15: 


\begin{tabular}{|c|c|}
\hline $\begin{array}{l}\text { VIII } \\
\{\text { Like a }\}^{\text {repd }} \text { Poet hidden } \\
\text { In the light of thought, } \\
\text { Singing hymns unbidden, } \\
\text { Till the world is wrought } \\
\text { [To sympathy with hopes and fears it } \\
\text { heeded not: } \\
\text { IX } \\
\left\{\mathrm{L}\{\mathrm{i}\}^{\text {asson }}{ }^{\mathrm{k} e} \text { a }\right\}^{\text {repd }} \text { a } \mathrm{h}\{\mathrm{i}\}^{\text {asson }} \text { gh- } \\
\text { In a palace tower, } \\
\text { Soothing her love-laden } \\
\text { Soul in secret hour } \\
\text { With music sweet as love, which } \\
\quad \text { [overflows her bower: } \\
\text { X } \\
\text { \{Like a }\}^{\text {repd a glow-worm golden }} \\
\text { In a dell of dew, } \\
\text { Scattering unbeholden } \\
\text { Its aërial hue } \\
\text { [Among the flowers and grass which } \\
\text { screen it from the view! } \\
\text { XI } \\
\text { Till the scent it gives } \\
\text { [Makes faint with too much sweet } \\
\text { those heavy-wingèd thieves: }\end{array}$ & 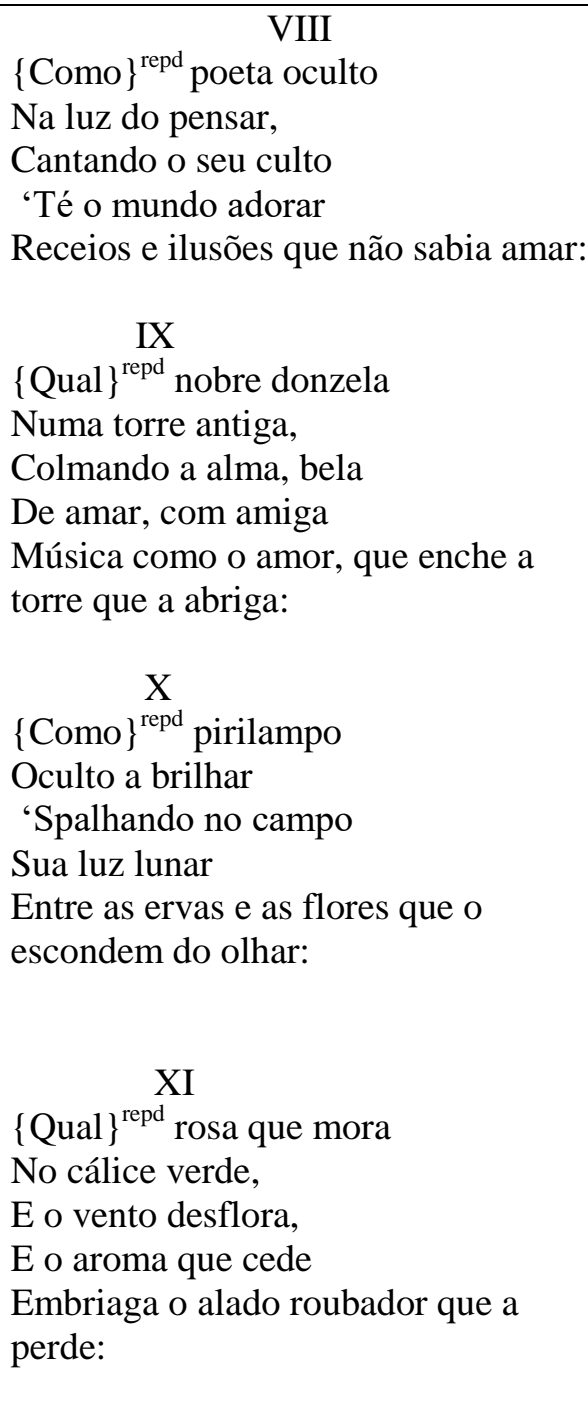 \\
\hline
\end{tabular}

\section{Exemplo de estudo de caso}

Candid he is, and courteous therewithal,

Nor, as he once was wont, in the far prime,

Flashes his scorn to heaven; - nor as the [mime

Of after-days, with antic bestial

Convenes the ape in man to carnival; Nor as the cynic of a later time
Cândido está,cortês, e cordial,

Nem como em tempos primitivos ralha

Seu riso com o céu; nem chamar calha,

Qual o histrião de depois, com bestial

Esgar, o símio em nós a carnaval;

Nem, qual do cínico ulterior, cascalha 


\begin{tabular}{|c|c|}
\hline $\begin{array}{l}\text { Jeers, that his laughter, like a jangled chime, } \\
\text { Rings through the abyss of our eternal fall. }\end{array}$ & $\begin{array}{l}\text { Seu riso, carrilhão que se baralha, } \\
\text { Pelo abismo da queda original. }\end{array}$ \\
\hline $\begin{array}{l}\text { But now, in courtliest modes of cultured } \\
\text { [grace, } \\
\text { He glories in the growth of good, his glance }\end{array}$ & 'stima do bem o aumento, e o seu olhar \\
\hline Beaming benignant as he bids us trace & Brilha benigno, e aponta em tudo o dia \\
\hline $\begin{array}{r}\text { Good everywhere - till, as mere motes that } \\
\text { [dance }\end{array}$ & Do bem, e, como pó no sol a ondear, \\
\hline Athwart the sunbeams, all things evil and base & Todo o mal fulge do ouro que irradia \\
\hline Glint golden in his genial tolerance. & A sua tolerância modelar. \\
\hline
\end{tabular}

\section{Anotação}

$\{\mathrm{C}\}^{\text {ali }}$ andid he is, and $\{\mathrm{c}\}^{\text {ali }}$ ourteous [therewithal,

$\{\mathrm{Nor}\}^{\text {repd }}$, as he $\{\mathrm{o}\}^{\text {ali }}$ nce $\{\mathrm{w}\}^{\text {ali }}$ as $\left[\{\mathrm{w}\}^{\text {ali }}\right.$ ont, in the $\mathrm{fa}\{\mathrm{r}\}^{\text {ali }} \mathrm{p}\{\mathrm{r}\}^{\text {ali }}{ }^{\text {ime }}$

Flasheshis $\operatorname{sc}\{0\}^{\text {asson }}$ rn to heaven; $\left[\left\{\mathrm{n}\{\mathrm{o}\}^{\text {asson }} \mathrm{r}\right\}{ }^{\text {repd }}\right.$ as the mime

Of after-days, with antic bestial

$\{C\}^{\text {ali }}$ onvenes the ape in man to

$$
\left[\{c\}^{\text {ali }}\right. \text { arnival; }
$$

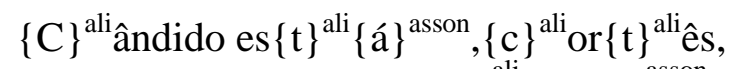
$\left[\mathrm{e}\{\mathrm{c}\}^{\text {ali }}\right.$ ordi $\{\mathrm{a}\}^{\text {asson }} 1$,

$\left\{\mathrm{N}\{\mathrm{em}\}^{\text {asson }}\right\}^{\text {repd }}$ comoem $\{\mathrm{t}\}^{\text {ali }}\{\mathrm{em}\}^{\text {asson }}$ pos [primi $\{t\}{ }^{\text {ali }}$ ivos ralha

$\{\mathrm{S}\}^{\text {ali }}\{\mathrm{eu}\}^{\mathrm{ri}}$ riso com o $\{\mathrm{c}\}^{\text {ali }}\{\text { éu }\}^{\mathrm{ri}}$; $\left[\{\text { nem }\}{ }^{\text {repd }} \text { cham }\{a\}\right\}^{\text {asson }} \mathrm{r}\left\{\{a\}{ }^{\text {asson }}\right.$ lha,

$\mathrm{Qu}\{\mathrm{al}\}^{\text {ri }} \mathrm{o}$ histrião de depois, com $\left[\right.$ besti $\{\text { al }\}^{\text {ri }}$

Esg $\{a\}^{\text {asson }} r$, o símio em nós a

$$
\left[\{c\}^{\text {ali }} \operatorname{arnav}_{a}\right\}^{\text {asson }} 1 ;
$$




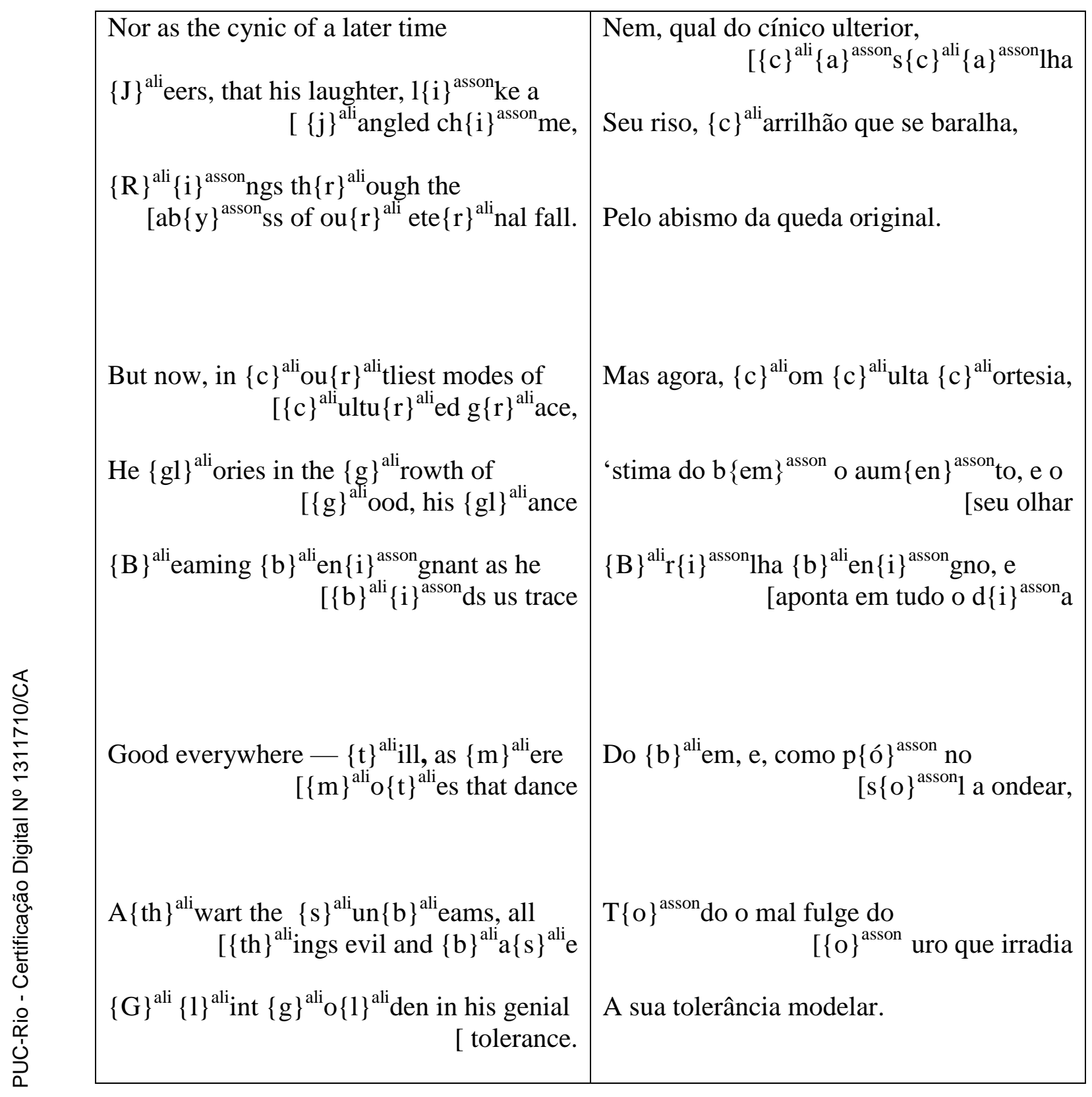

